\title{
A Road Map for Success: How Northwest Manufactured Housing Conservation Efforts Revolutionized an Industry
}

W.L. Gilbertson ${ }^{(a)}$

F.V. DiMassa

A.D. Lee

S.A. Onisko ${ }^{(b)}$

April 1993

Prepared for

the Bonneville Power Administration under a Related Services Agreement with the U.S. Department of Energy Contract DE-AC06-76iRLO 1830

(a) private contractor, Portland, Oregon

(b) Bonneville Power Administration, Portland, Oregon

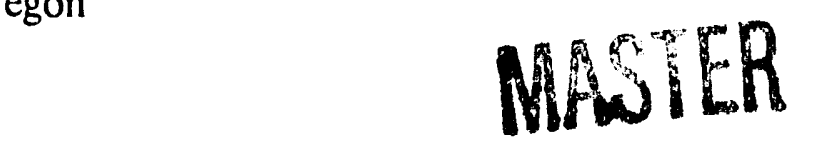

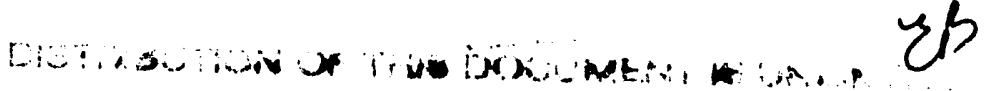




\section{SUMMARY}

This informal history chronicles the evolution of an ongoing Bonneville Power Administration (Bonneville/BPA) effort to improve the energy efficiency of manufactured homes. Over the past 9 years, Bonneville's manufactured housing project has undertaken a great many impressive activities, including

1. developing numerous technical studies on the energy performance of manufactured homes that helped the industry to significantly improve the energy efficiency of the manufactured homes constructed in the Pacific Northwest

2. establishing and fostering industry/ government/private association work groups and enabling these groups to develop and work toward the achievement of common regional goals

3. working with the manufactured housing industry in the Pacific Northwest to develop practical, energy-efficient designs and feasible construction techniques to fabricate these designs

4. encouraging related component industries to design and bring to market more energyefficient products

5. providing a forum for the development of a regionwide public-private cooperative program and working with all other interested parties to ensure that every electrically heated manufactured home built in the Pacific Northwest will meet the nation's highest level of energy efficiency

6. extending technical and programmatic information to state agencies nationwide in an important information transfer and exchange effort.
Between 10,000 and 13,000 electrically heated manufactured homes are built in the Pacific Northwest each year, accounting for nearly $30 \%$ of the region's new electrically heated homes (NWPPC 1991). All manufactured housing in the United States has to meet federal building standards - which include energy efficiency standards - set by the U.S. Department of Housing and Urban Development (HUD). Because these standards were established in 1976 and are applied to broad geographic areas embracing a range of climate conditions, they fail to approach the levels of cost-effective energy efficiency developed in the Pacific Northwest. Although the Housing and Community Development Act of 1987 instructed HUD to strengthen the national standards for manufactured housing and a new energy standard has been proposed and developed, it has not yet been approved. However, even the new standard will not approach the levels of energy efficiency that are being achieved in the Pacific Northwest.

On April 1, 1992, a unique energyefficiency program was established in the Pacific Northwest: the Manufactured Housing Acquisition Program (MAP). MAP is a cooperative agreement forged by the region's electric utilities, Bonneville, and every one of the region's manufacturers of factory-built, "HUD code" homes. Through MAP, public and private electric utilities in the region provide financial incentives that permit manufacturers to produce highly energyefficient homes at a marketable price. These homes far exceed the energy performance standards established by the HUD code, which preempts any state or local building codes for this unique housing category. MAP acquires a valuable energy resource at an estimated cost of only about two-thirds the cost of the same power from new generating plants (Bleything 1992). The voluntary energy performance standards, developed and implemented through 
a first-of-its-kind public/private cooperative venture, surpass any standards being applied to manufactured housing elsewhere in the United States. They are expected to save the region 7 to 9 average megawatts (AMW) a year enough electricity to supply about 5,000 Pacific Northwest homes with all their annual electric power needs (Russell 1992).

By documenting the evolution of its manufactured housing project from humble beginnings through turbulent, often complex, technical developments and into the paramount achievement of those participating in the project, Bonneville intends to provide readers the opportunity to see the processes and enterprise required to develop a successful public/private venture. This readable, informal history will permit those interested in the project the opportunity to "watch" as the difficulties and obstacles created by diversity of interest are ultimately resolved through cooperation, understanding, and -- at times -- "a little bit of luck." 


\section{ACRONYMS}

\begin{tabular}{|c|c|}
\hline AAHX & air-to-air heat exchanger \\
\hline ac & alternating current \\
\hline $\mathrm{ACH}$ & air changes per hour \\
\hline Act (the) & Pacific Northwest Electric Power Planning and Conservation Act \\
\hline ADA & airtight drywall approach \\
\hline ALC & Air Leakage Control \\
\hline ANSI & American National Standards Institute \\
\hline BPA/Bonneville & Bonneville Power Administration \\
\hline CFC & Criterion Formation Committee \\
\hline CFR & Code of Federal Regulations \\
\hline Council/NWPPC & Northwest Power Planning Council \\
\hline COV & coefficient of variation \\
\hline CSPE & Columbia Storage Power Exchange \\
\hline CVA & Columbia Valley Authority \\
\hline DAPIA & Design Approval Primary Inspection Agency \\
\hline dc & direct current \\
\hline DMC & Data Management Committee \\
\hline DOE & U.S. Department of Energy \\
\hline DSI & direct service industry \\
\hline DW & double-wide \\
\hline ECM & energy conservation measure \\
\hline EIS & environmental impact statement \\
\hline ELA & effective leakage area \\
\hline ELCAP & End-Use Load and Conservation Assessment Program \\
\hline EPRI & Electric Power Research Institute \\
\hline FDAS & field data acquisition system \\
\hline FDR & Franklin Delano Roosevelt \\
\hline FmHA & Farmer's Home Administration \\
\hline FMHCSS & Federal Manufactured Housing Construction and Safety Standard \\
\hline
\end{tabular}




\begin{tabular}{|c|c|}
\hline FY & fiscal y'ear \\
\hline GRI & Glen River Industries \\
\hline HUD & U.S. Department of Housing and Urban Development \\
\hline IAQ & indoor air quality \\
\hline IOU & investor-owned utility \\
\hline IPIA & Inspection Primary Inspection Agency \\
\hline JPPC & Joint Power Planning Council \\
\hline LBL & Lawrence Berkeley Laboratories \\
\hline MAC & Manufactured Housing Acquisition Committee \\
\hline MAP & Manufactured Housing Acquisition Program \\
\hline MCS & Model Conservation Standards \\
\hline MEO & most efficient organization \\
\hline MHA & Manufactured Housing Association \\
\hline MHI & Manufactured Housing Institute \\
\hline MHTAG & Manufactured Housing Technical Advisory Group \\
\hline MPS & minimum property standards \\
\hline NCSBCS & National Conference of States on Building Codes and Standards \\
\hline NMHMHAS & National Mobile Home Manufactured Housing Appràisal System \\
\hline NORIS & Northwest Residential Infiltration Survey \\
\hline NRDC & Natural Resources Defense Council \\
\hline NWEC & Northwest Energy Code \\
\hline NWPPC/Council & Northwest Power Planning Council \\
\hline ODOE & Oregon Department of Energy \\
\hline $\mathbf{P a}$ & pascals \\
\hline PNL & Pacific Northwest Laboratory \\
\hline PNCA & Pacific Northwest Coordination Agreement \\
\hline PNUCC & Pacific Northwest Utilities Conference Committee \\
\hline PNWRPC & Pacific Northwest Regional Planning Commission \\
\hline Power Plan (1986) & 1986 Northwest Conservation and Electric Power Plan \\
\hline PRISM & Princeton Scorekeeping Method \\
\hline PUC & public utility commission \\
\hline PUD & public utility district \\
\hline
\end{tabular}


RCDP

RDAS

RFP

RSDP

SAA

SEO

SGC

SRC

SW

TLP

TVA

UBC

$\mathrm{U}_{\text {。 }}$

WPPSS

WSEO
Residential Construction Demonstration Project

Residential Data Acquisition System

request for proposal

Residential Standards Demonstration Project

State Administrative Agencies

state energy office

Super Good Cents

Specifications Review Committee

single-wide

The Levy Partnership

Tennessee Valley Authority

Universal Building Code

transmission heat loss coefficient

Washington Public Power Supply System

Washington State Energy Office 


\section{CONTENTS}

CHAPTER 1: THE SETTING -- A Region of Surprising Contrasts . . . . . . . . . . . . . 1.1

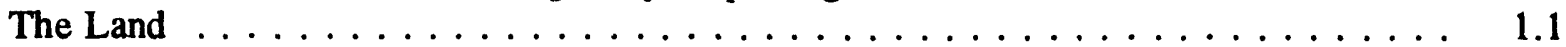

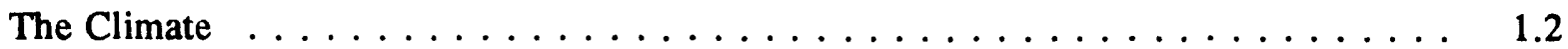

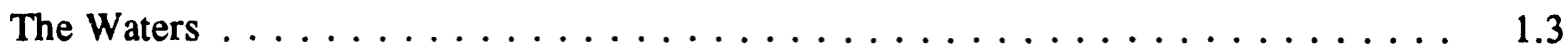

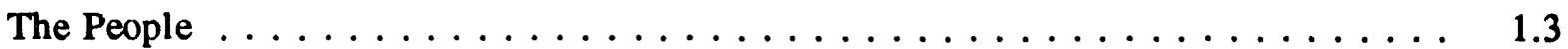

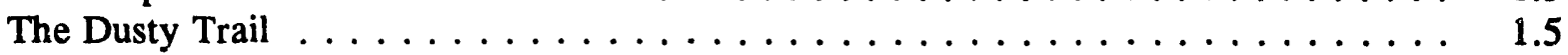

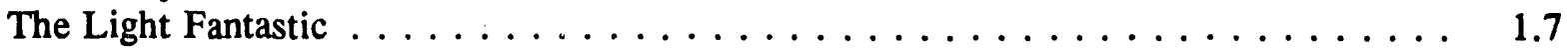

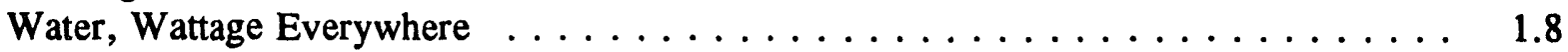

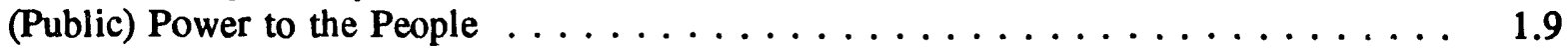

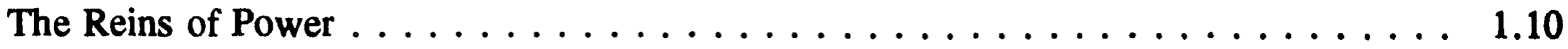

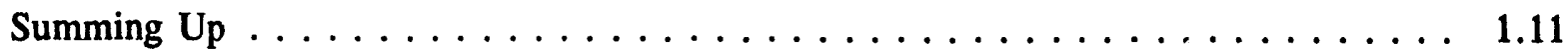

CHAPTER 2: THE BACKGROUND - A New Order . . . . . . . . . . . . . . . 2.1

Creating New Resources . . . . . . . . . . . . . . . . . . . . . . . . 2.2

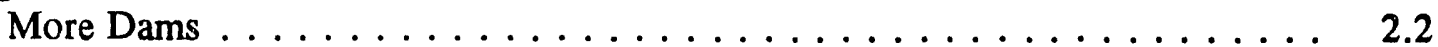

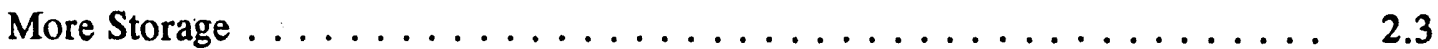

The Coordination Agreement $\ldots \ldots \ldots \ldots \ldots \ldots \ldots \ldots \ldots$

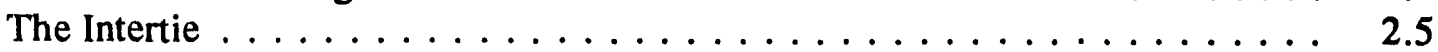

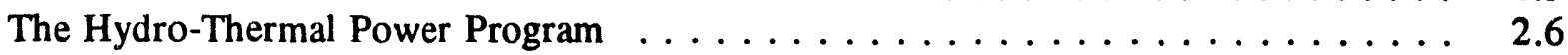

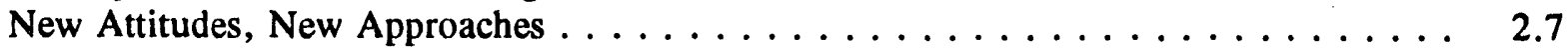

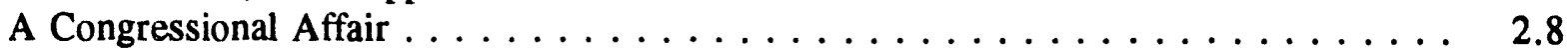

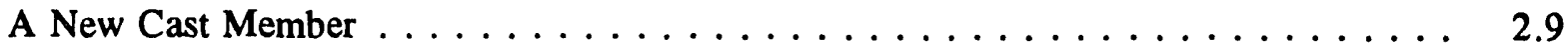

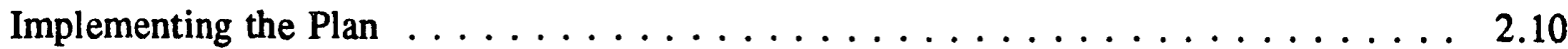

The Council's Plan and Building Standards $\ldots \ldots \ldots \ldots \ldots \ldots \ldots \ldots$

CHAPTER 3: MANUFACTURED HOUSING - A Timely, Technical Stimulus . . . . . 3.1

First Steps in a New Direction . . . . . . . . . . . . . . . . . . . . . 3.1

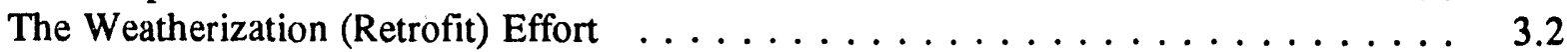

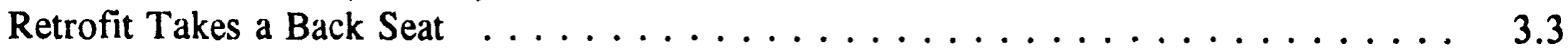

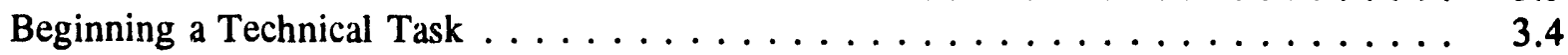

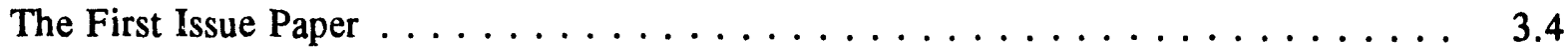

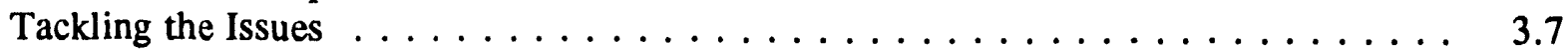

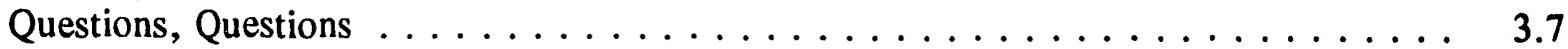

CHAPTER 4: LEARNING THE ROPES -- A Name, a Database, a Vision . . . . . . . 4.1

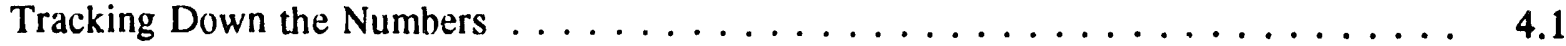

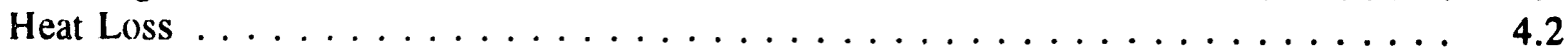

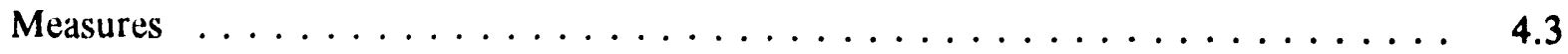

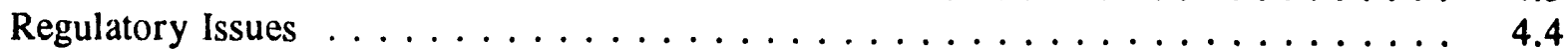

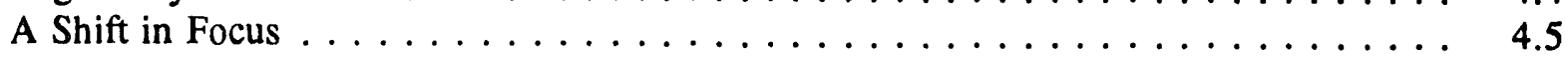

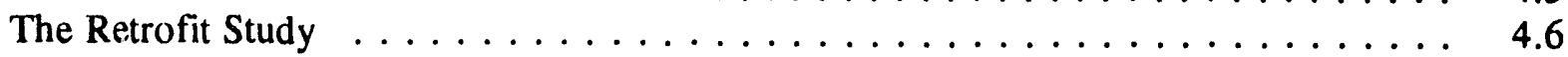

New Players, New Plans $\ldots \ldots \ldots \ldots \ldots \ldots \ldots$ 
CHAPTER 5: ANOTHER WORLD -- DAPIAs and IPIAs and Indians Too . . . . . . . . 5.1

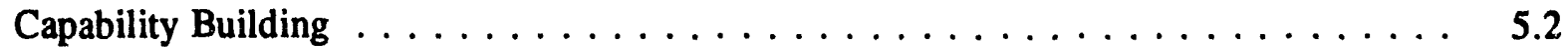

Demonstrating the Savings $\ldots \ldots \ldots \ldots \ldots \ldots \ldots \ldots \ldots \ldots$

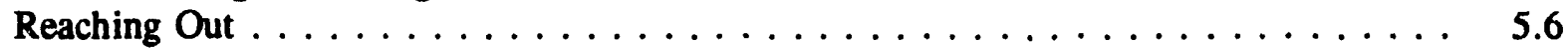

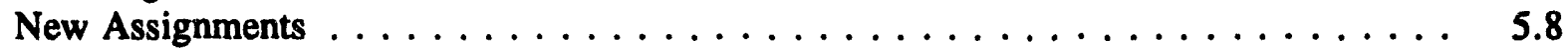

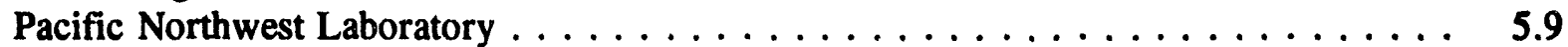

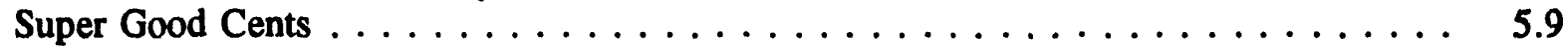

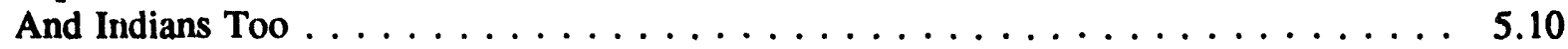

CHAPTER 6: TIGHTENING THE FOCUS - Hard Data, Firm Marketing Plans . . . . . 6.1

The Plan - Bonneville's Overview ................... 6.1

Thermal Performance ......................... 6.3

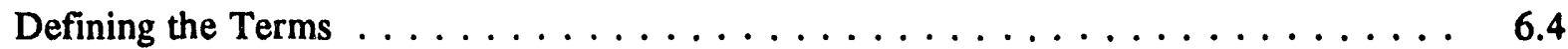

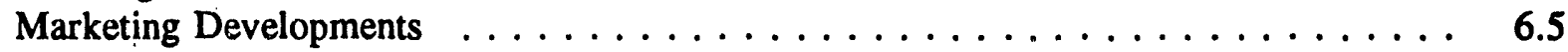

Reviewing the Situation $\ldots \ldots \ldots \ldots \ldots \ldots \ldots \ldots$

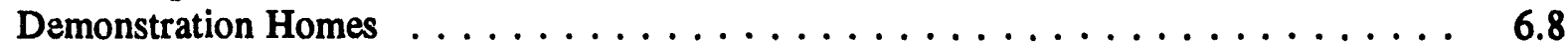

Super Good Cents . . . . . . . . . . . . . . . . . . . . . 6.9

CHAPTER 7: REACHING FOR CONCLUSIONS - And for Consensus . . . . . . . . . 7.1

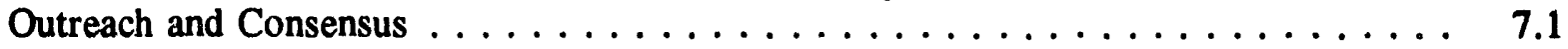

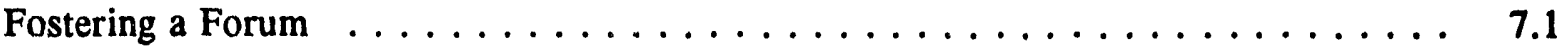

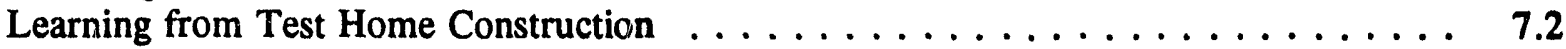

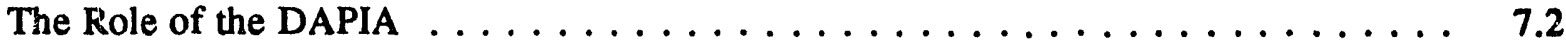

Preliminary Thermal Performance Data $\ldots \ldots \ldots \ldots \ldots \ldots \ldots \ldots$

Preliminary Cost Analysis . . . . . . . . . . . . . . . . . 7.4

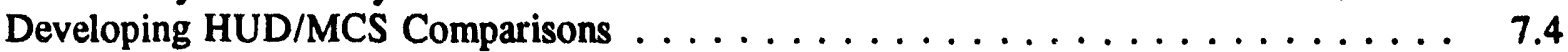

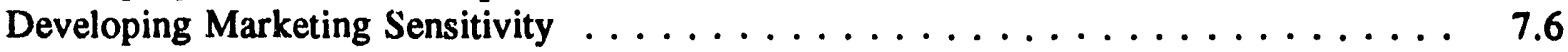

Building a Constituency $\ldots \ldots \ldots \ldots \ldots \ldots \ldots \ldots$

A Robust Response . . . . . . . . . . . . . . . . . . . 7.9

CHAPTER 8: COUNTDOWN TO CLOSURE - Building to a Regional Test . . . . . . . 8.1

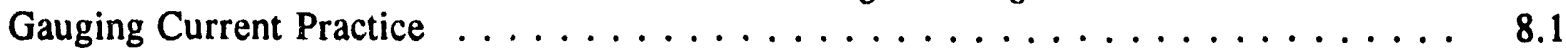

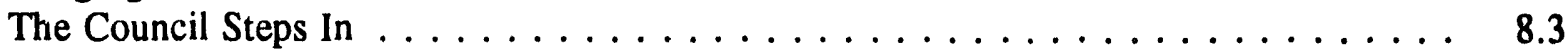

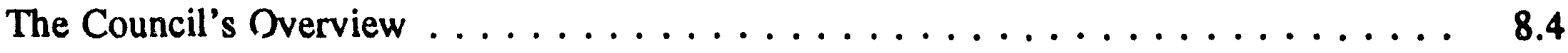

The June Meeting $\ldots \ldots \ldots \ldots \ldots \ldots \ldots \ldots \ldots \ldots \ldots \ldots \ldots$

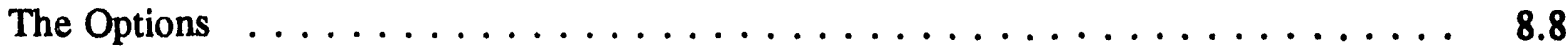

A Long, Hot Summer $\ldots \ldots \ldots \ldots \ldots \ldots \ldots \ldots \ldots \ldots \ldots$

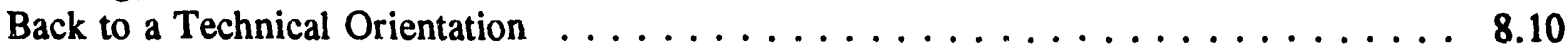


CHAPTER 9: RCDP -- Readying an Innovation $\ldots \ldots \ldots \ldots \ldots \ldots . \ldots \ldots$

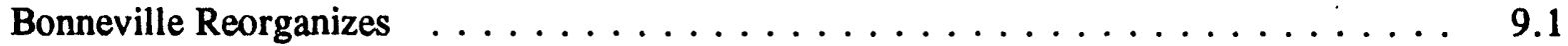

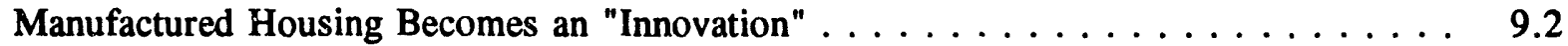

Making the State Energy Office Fit $\ldots \ldots \ldots \ldots \ldots \ldots . \ldots \ldots$

Developing Super Good Sensible Specifications $\ldots \ldots \ldots \ldots$. . . . . . . . . . . . . 9.4

The Super Good Cents/RCDP Technical Specifications . . . . . . . . . . . . . . . 9.5

Compliance Procedures $\ldots \ldots \ldots \ldots \ldots \ldots \ldots \ldots$

Participating Manufacturers $\ldots \ldots \ldots \ldots \ldots \ldots \ldots \ldots$

The Marketing Program $\ldots \ldots \ldots \ldots \ldots \ldots \ldots \ldots$

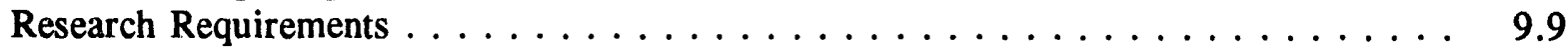

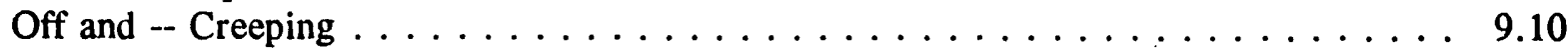

CHAPTER 10: A SLOW START -- Problems and Promise $\ldots \ldots \ldots \ldots \ldots . \ldots$

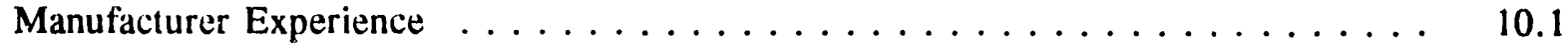

Dealer Experience . . . . . . . . . . . . . . . . . . . . 10.3

Consumer Response $\ldots \ldots \ldots \ldots \ldots \ldots \ldots \ldots$

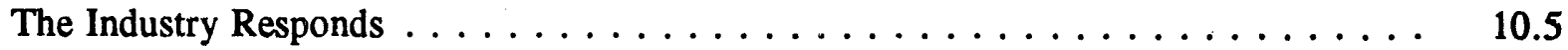

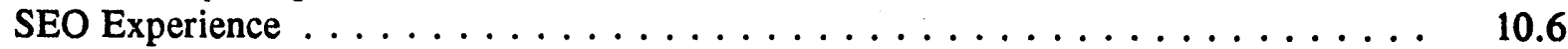

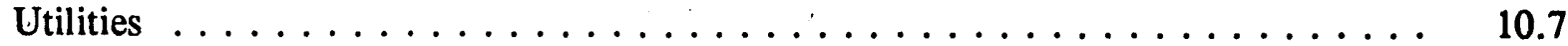

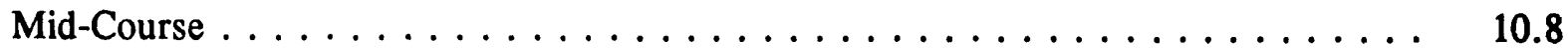

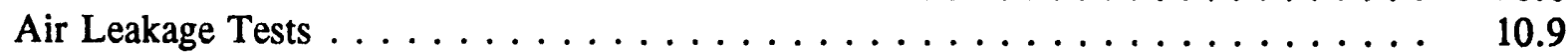

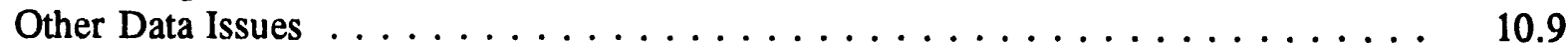

CHAPTER 11: ENTER THE DMC -- BPA Continues/Expands Group Activity . . . . . . 11.1

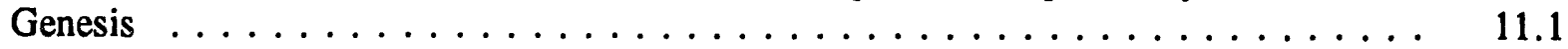

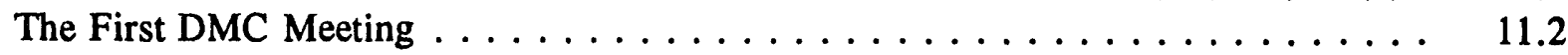

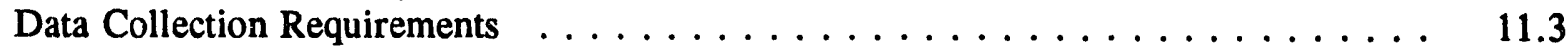

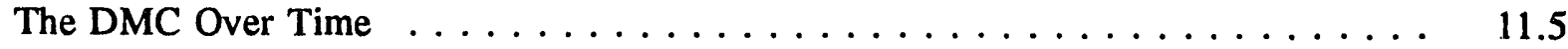

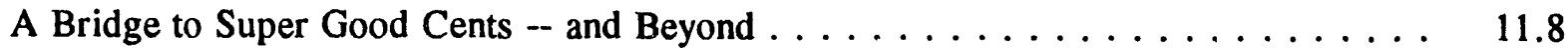

CHAPTER 12: RCDP TAKES OFF - The Proof is in the Program! . . . . . . . . . 12.1

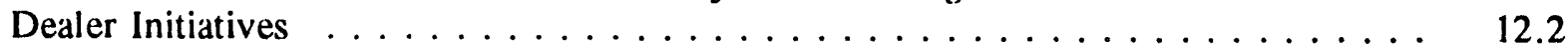

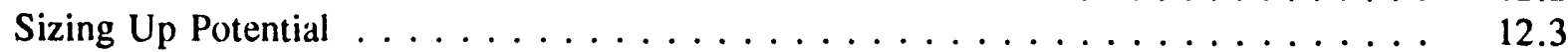

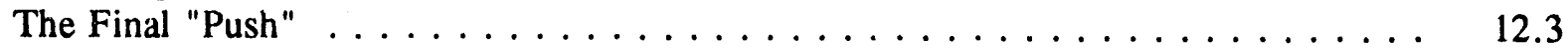

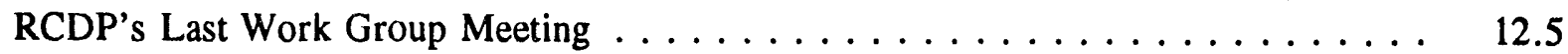

The Importance of Demonstration $\ldots \ldots \ldots \ldots \ldots \ldots \ldots \ldots \ldots \ldots \ldots$

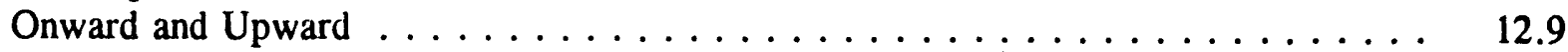

CHAPTER 13: MAINTAINING MOMENTUM -- Super Good Cents and Beyond . . . . 13.1

Super Good Cents's First Work Group Meeting . . . . . . . . . . . . . . . . . 13.1

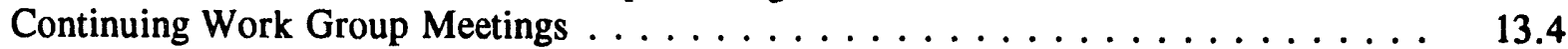

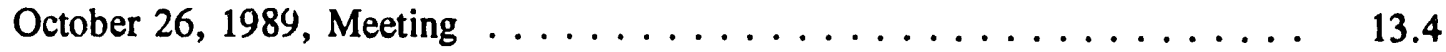

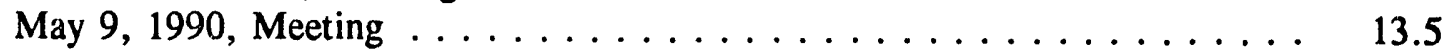

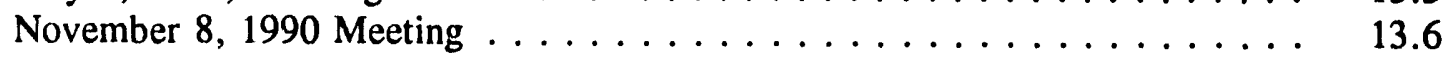

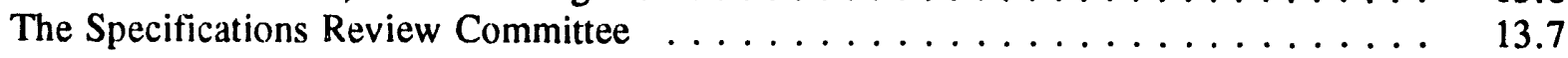

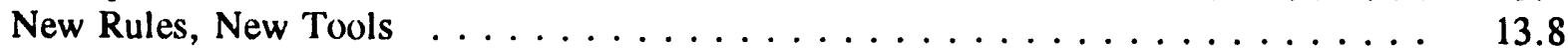

Evaluating RCDP and Super Good Cents $\ldots \ldots \ldots \ldots \ldots \ldots \ldots$ 
CHAPTER 14: MAP -- The Ultimate Conservation Program! . . . . . . . . . . . 14.1

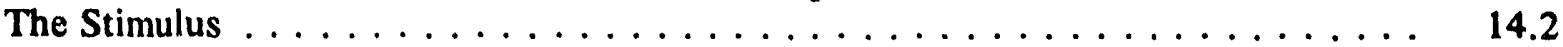

Super Good Cents Uncertainties $\ldots \ldots \ldots \ldots \ldots \ldots \ldots \ldots \ldots \ldots \ldots$

HUD Code Developments . . . . . . . . . . . . . . . . 14.3

Utility Hook-Up Fees . . . . . . . . . . . . . . . . . . . 14.3

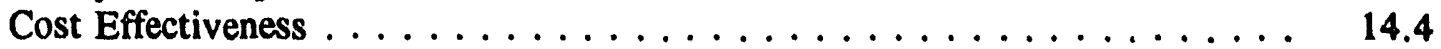

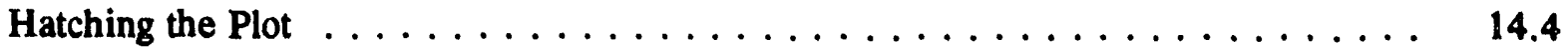

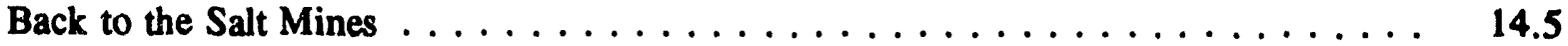

Product Design . . . . . . . . . . . . . . . . . . 14.6

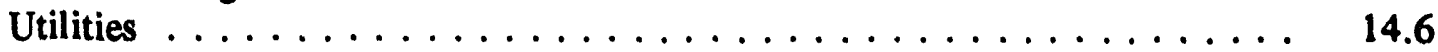

On-Site Quality Assurance . . . . . . . . . . . . . . . . . 14.6

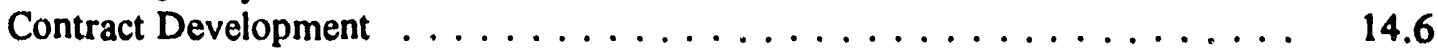

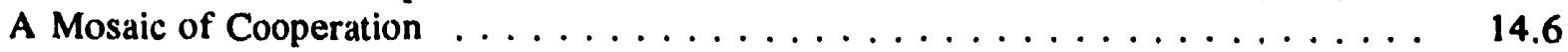

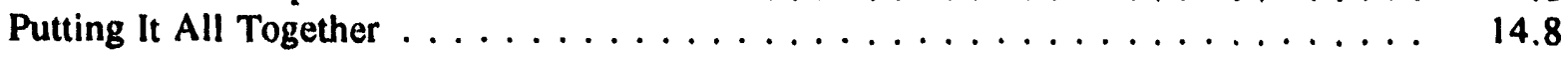

CHAPTER 15: REFERENCES $\ldots \ldots \ldots \ldots \ldots \ldots \ldots \ldots$

MANUFACTURED HOUSING HISTORY $\ldots \ldots \ldots \ldots \ldots \ldots \ldots$. . . . . 


\section{FIGURES}

Bonneville Power Administration Area and District Offices $\ldots \ldots \ldots \ldots \ldots \ldots$

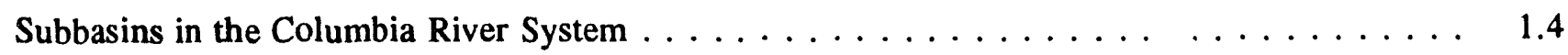

Columbia River Basin Hydroelectric Projects by $1987 \ldots \ldots \ldots \ldots \ldots$. . . . . . . . . 2.4

Firm Electricity Loads and Resources $\ldots \ldots \ldots \ldots \ldots \ldots$

Northwest Manufactured Housing Programs: A Family Tree . . . . . . . . . . . . . 5.2

Super Good Cents Certificate of Participation . . . . . . . . . . . . . . . . 5.9

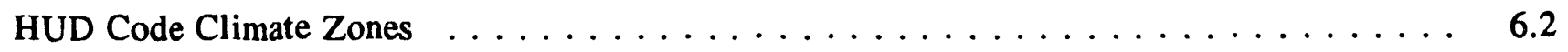

Bonneville Power Administration Offices/Office of Energy Resources . . . . . . . . . . . 9.1

Energy Efficiency in Manufactured Housing $\ldots \ldots \ldots \ldots \ldots \ldots \ldots$

TABLES

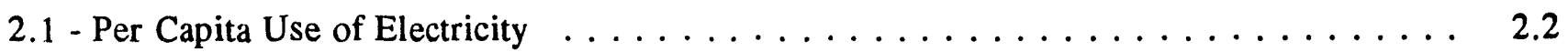

2.2 - Forecast of Demand for Electricity and Price Projections $\ldots \ldots \ldots \ldots$

3.1 - Performance Standards for Space Heating Requirements . . . . . . . . . . . . . . 3.4

3.2 - Manufactured Homes In BPA Service Area $\ldots \ldots \ldots \ldots \ldots \ldots$

4.1 - Typical Mobile/Manufactured Home . . . . . . . . . . . . . . . 4.7

5.1 - Prototype Dimensions and Insulation Packages $\ldots \ldots \ldots \ldots \ldots$

5.2 - Estimated Annual Energy Use and Savings Using SUNDAY, M/M Model, and HUD

Slide Rule . . . . . . . . . . . . . . . . . . . . . . 5.4

6.1 - Pacific Northwest Mobile Home New Construction, Medium Case . . . . . . . . . 6.2

6.2 - Estimated 1983 Single-Family Electrically Heated New Home Sales . . . . . . . . 6.3

6.3 - Estimated Regional Manufactured Home Sales by Year . . . . . . . . . . . . . . 6.8 


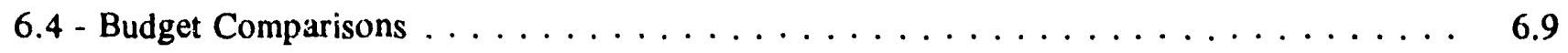

7.1 - Comparison of Computer Model Estimated Annual Energy Budgets and Customer Cost

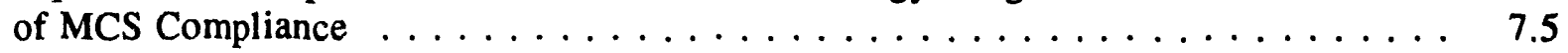

7.2 - Option Markup of Tulalip Homes $\ldots \ldots \ldots \ldots \ldots \ldots \ldots \ldots \ldots \ldots \ldots \ldots \ldots \ldots$

7.3 - MCS Thermal Performance Expressed as Heat Loss $\ldots \ldots \ldots \ldots \ldots \ldots$

7.4 - HUD Standard Adjusted for Infiltration $\ldots \ldots \ldots \ldots \ldots \ldots \ldots \ldots \ldots \ldots \ldots$

7.5 - A Comparison of Maximum Allowable Incremental $\ldots \ldots \ldots \ldots \ldots \ldots \ldots .7 .7$

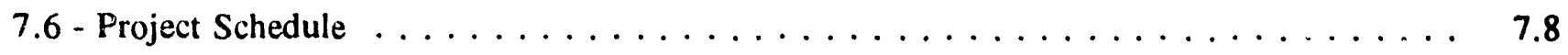

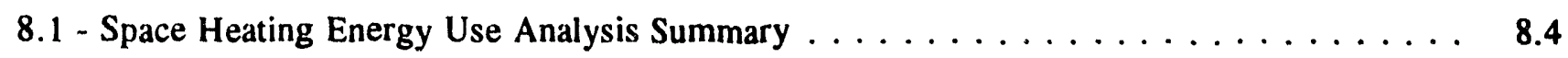

8.2 - HUD Code Manufactured Homes Sited in Northwest $\ldots \ldots \ldots \ldots \ldots . \ldots . \ldots . \ldots$

8.3 - Average New HUD Code Home Insulation Level Comparisons $\ldots \ldots \ldots \ldots . \ldots .6$

8.4 - Projected Electric Space Heating Use for New HUD Code Homes $\ldots \ldots \ldots \ldots \ldots .8$

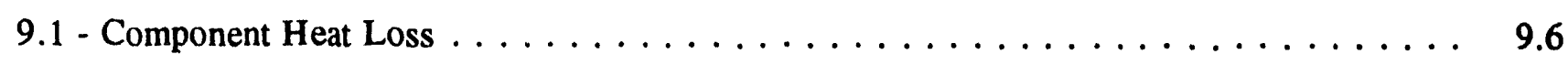

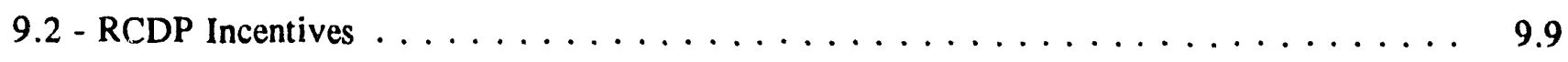

10.1 - Manufactured Housing Air Leakage Performance $\ldots \ldots \ldots \ldots \ldots \ldots \ldots . \ldots .10 .10$

12.1 - RCDP Home Sales . . . . . . . . . . . . . . . . 12.4

13.1 - SGC Reference Path for Electrically Heated Manufactured Residences . . . . . . . 13.9 


\section{CHAPTER 1: THE SETTING -- A Region of Surprising Contrasts}

Since 1983, the Bonneville Power Administration (Bonneville/BPA) has spearheaded an ongoing cooperative effort to explore, quantify, and capture the energy savings inlıerent in the Pacific Northwest's new manufactured housing stock. To understand the motivation and course of this effort -- referred to at different times by different program titles but generally identified as the "manufactured housing project" -- it is necessary to know something of the region's characteristics as well as the peculiar "rules of the road" that apply to energy in the Pacific Northwest. These are as singular as the region itself.

A unique region of surprising contrasts, the U.S. Pacific Northwest resists easy classification. In fact, it even lacks consistent boundaries. Some authorities include northern California and exclude Montana; some include Idaho and some do not. As used in this report and generally understood within the region, the Pacific Northwest is defined as Bonneville's primary power marketing area, which is composed of four states -- Washington, Oregon, Idaho, and (western) Montana. Differences among these states are cultural, economic, and historical as well as geographic and climatological. Even within their borders, each of these states has internal variations and contradictions.

Whatever it is, it's certainly not a region without variety. Many people do not realize the Pacific Northwest not only has tall trees and virgin forests but also includes vast expanses of high desert. Although it is often characterized as an area of only mild maritime climate, some sections of the Pacific Northwest undergo severe winters and blistering summer heat. It has vineyards and wheat fields and llamas and sheep; aluminum smelting and precision casting and paper mills and state-of-the-art electronics. It has covered bridges, log cabins, and space needles; rodeos, county fairs, and opera; snow skiing, wind surfing, and polo. Yes, polo.

\section{The Land}

The Pacific Northwest could be called a latecomer - politically and geologically. It is part of the last great geological addition to North America and the newest major continental uplift on Earth (Norwood 1981). Before this, ti:e shore of the ancient Pacific roughly followed the outline of today's Rocky Mountain western foothills and the Pacific Northwest was a shallow submarine shelf. Beginning about 300 million years ago, the Rockies rose and then eroded, creating inland seas and marshlands with a warm climate, tropical growth, and the Pacific Northwest's very own dinosaurs. About 72 million years ago, the second major uplift began, creating the second Rocky Mountains and, later, the Cascade and Coastal Ranges. No dinosaurs.

Born in violence and volcanism, the Cascade Range stretches in a north-south axis for $\mathbf{4 8 5}$ miles across Washington and Oregon (Findley et al. 1982). Huge solitary mountain peaks, actually volcanos deceptively covered in white, punctuate the lower lying ridges and serve as awesome landmarks -- Three Sisters, Hood, St. Helens, Rainier, Baker, to name a few -- and even today have the power to inspire, to awe, to maim, and to kill. Long a barrier to any kind of movement (people, water, power, etc.), the Cascades are "a jumble of cliffs, canyons, and dense forest" (Kimerling 1985).

Numerous other mountain ranges dot the region - the Olympic Mountains, the Coast Range, the Selkirks -- with beauty and history of their own. The eastern part of the Pacific Northwest features steep mountains, rugged foothills, and precipitous canyons, including Hell's Canyon of the Snake River, the nation's deepest. None of these, however, affect the 


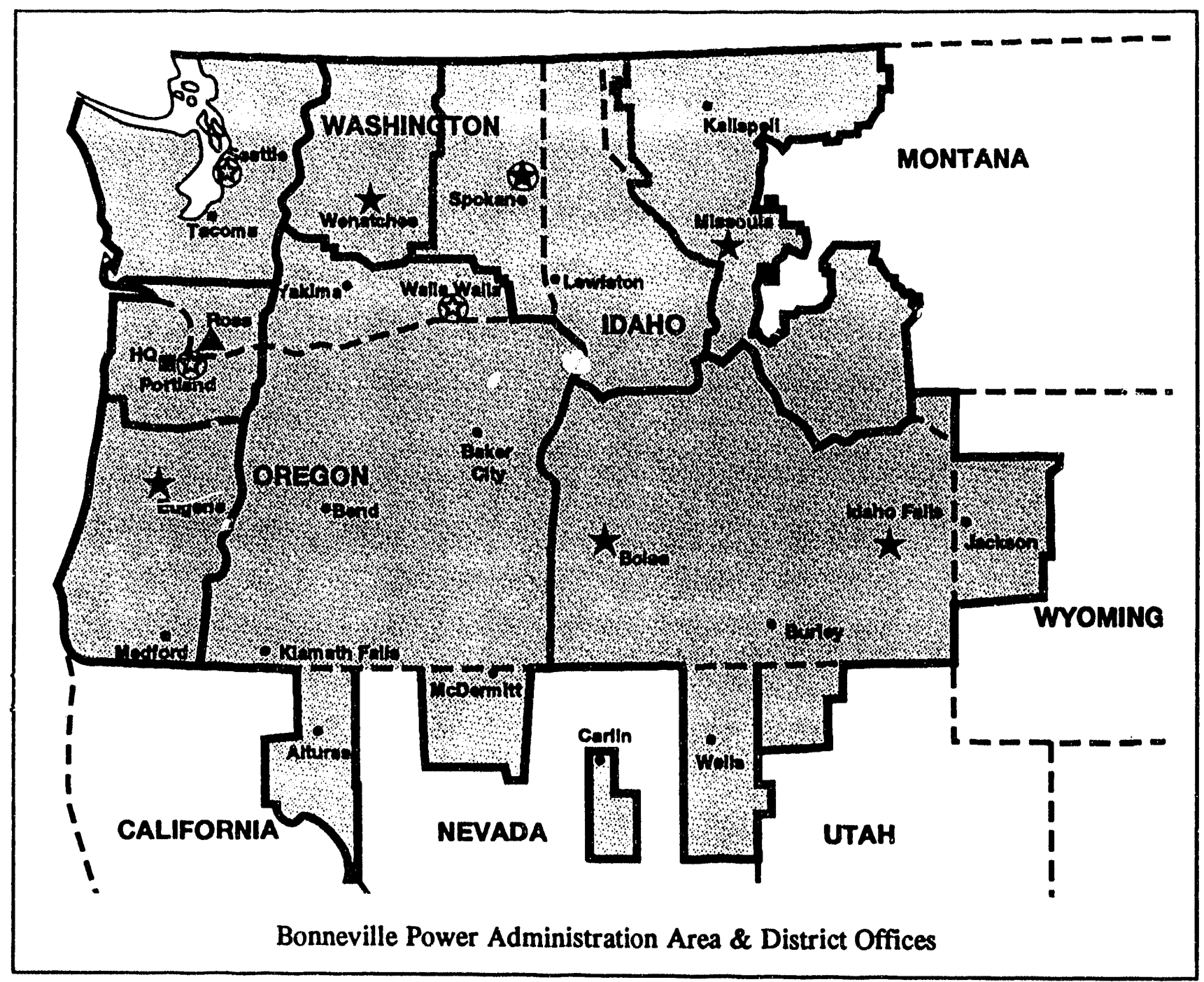

region's climate, culture, or economy as clearly and as markedly as the Cascades.

\section{The Climate}

"Climatic diversity is the hallmark of the Pacific Northwest" (Kimerling 1985). This diversity is created in large measure because the Cascade barrier prevents both moisture and moderate ocean temperatures from reaching the interior of the region. The region's other ranges and features contribute to further variations in temperature and precipitation within the broadly differentiated climate zones. In general, the region west of the Cascades has much more precipitation and milder temperatures than the areas inland. Areas in northern Idaho and Montana, on the western slope of the Continental Divide, have the most extreme climate in the region.

West of the Cascades, temperatures are above freezing from 240-300 days per year. East of the Cascades, however, the freeze-free season is generally less than 120 days. In parts of the Cascades and Idaho, the annual freezefree period can be less than $\mathbf{3 0}$ days (Kimerling 1985). These differences in temperature produce variations in amount and type of precipitation, in vegetation, economies, lifestyles, and even attitudes. 
To the east of the Cascades, other ranges -the Wallowas, Bitteroots, and Selkirks - rise high enough to again capture large amounts of moisture from the air (Kimerling 1985).

Farther again to the east, the western slopes of the Rockies capture moisture which falls mostly (and heavily) as snow during the long winters (Norwood 1981). Spring rains and snow melt produce...

\section{The Waters}

According to Cree and Sioux legends recorded in $1766-1767$, the sources of the four largest rivers in North America lay close together. From these sources, the Red River flowed North, the St. Lawrence flowed East, the Mississippi flowed South, and a "great stream" they called the Oregon flowed west (Morison 1965). That "great stream" was, of course, today's Columbia, a rush and realm of water powerful enough to brazen its way through the Cascade barrier to reach the sea and in the process carve a passageway and a network of waterways a thousand miles into the interior of the continent.

Except for a few coastal streams in Oregon and Washington, the Columbia watershed drains the entire region. The watershed is vast; it roughly conforms to the boundaries of the Pacific Northwest, unifying and defining the region. At least one authority considers the Columbia to be the outstanding natural resource of the region (Norwood 1981). According to another source, it is among the three key physical features that most strongly influence the history and development of the region -- the Cascades, the Columbia, and the Strait of Juan de Fuca (Kimerling 1985).

Formed by the Columbia and Snake River systems, the Columbia River basin covers 259,000 square miles, with about $15 \%$ of this area lying in Canada where the Columbia originates (Norwood 1981). The Columbia rises deceptively. At its beginning, it is placid and it flows north from a flat stretch of glacial silt, 2,619 feet above sea level in eastern British
Columbia (Morgan 1962). It ultimately finds its southward course about midway along Washington State's northern border, then curves eastward to meet the Snake River. The flow contributed by the Snake River system comes from the highest, most inland reaches of the region. In earlier times, the joined waters surged through the Cascades in a series of "fearsome rapids" (Morgan 1962).

\section{The People}

According to prevailing theory, the first human inhabitants of North America reached Alaska from Siberia over a land bridge and then migrated to the southeast. That means they reached the Pacific Northwest the same way that most of the later migrants did -- westward over the Rocky Mountains to stop their trek in the high deserts or continuing over the Cascades or through the Columbia Gorge to the western valleys (Kimerling 1985). Undoubtedly some of the early inhabitants -- again, like some of the later migrants -- reached the western valleys from the seas, possessed as they were of large ocean-going canoes (Findley et al. 1982).

The question of when the land was first settled is an open one; research is even now being conducted. Carbon-dating indicates that humans inhabited the Snake River Plain as long ago as 14,500 years and sites in Oregon have been dated at 13,000 years old. Estimates on the total population range from 75,000 to twice that number. What is known is that as a result of the variations in the land, the climate, and the resources available, a wide variety of cultures developed, eventually dividing into over 125 distinct tribal groups (Kimerling 1985).

There was no agriculture and there were no domesticated animals except the dog before horses were introduced by the Spanish.

Generally, the people who lived west of the Cascades depended largely on food from the sea. They built substantial wooden houses, large enough in many cases for a number of families. East of the Cascades, hunting was the 


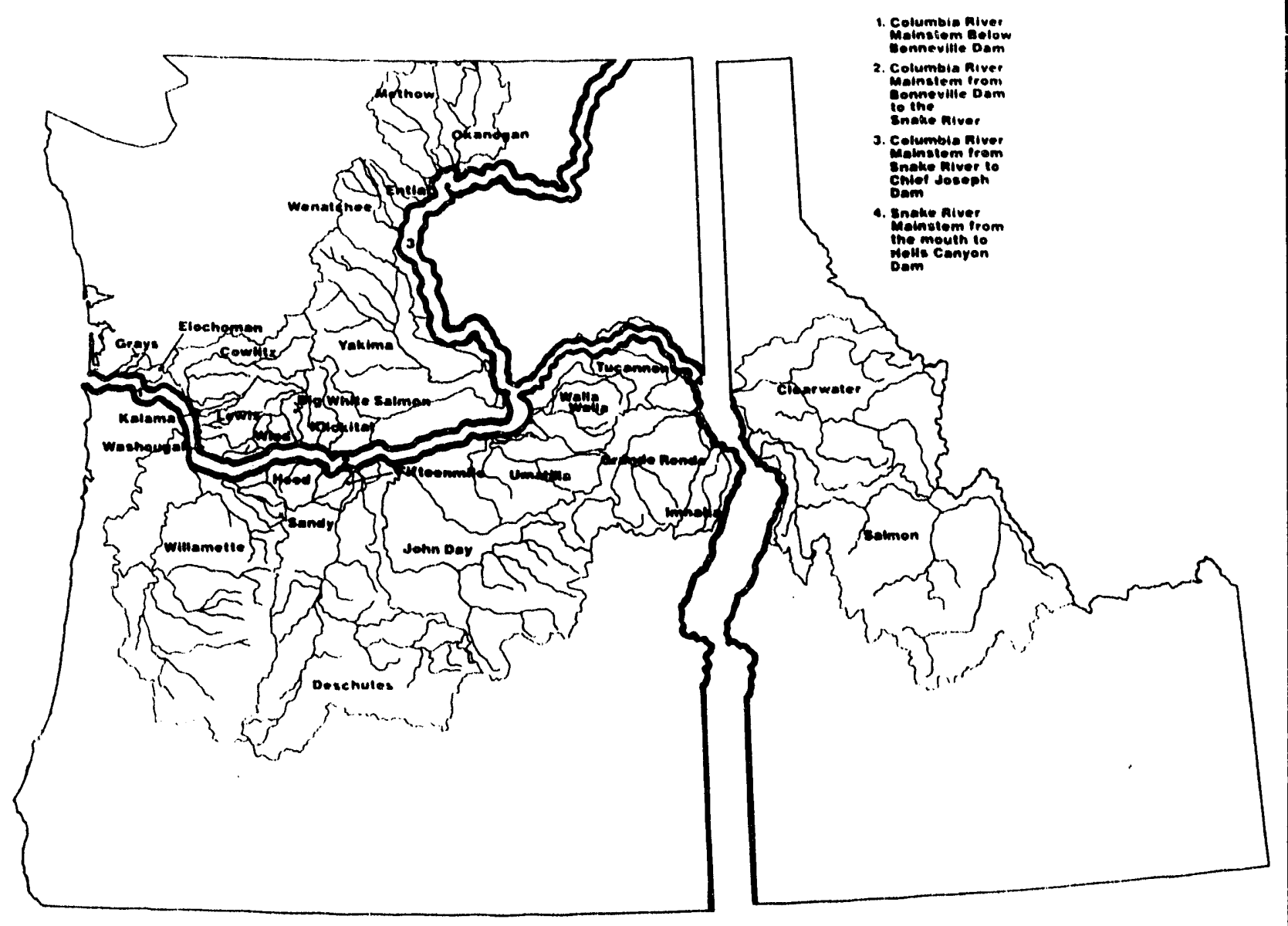

Subbasins in the Columbia River System

main source of food although fish were also important, particularly to the tribes with access to the salmon of the Columbia River. Even though the climate was severe in this area, housing was "not substantial, though more clothes were worn by members of these tribes than by the Coastal Indians" (Kimerling 1985).

This was an economy, by and large, of abundance. The Indians of the coast had invented the ceremony of the potlatch - giving away surflus wealth - and their initial contacts with Europeans were open and generous (Morgan 1962). The inhabitants of the region were nevertheless devastated by the arrival of the Europeans who carried diseases - smallpox, cholera, measles - to which the Native Americans had no resistance. By the mid1850 s, both the immune systems and the cultures of the Pacific Northwest native population had developed more resistance to the intruders, but the sheer number of immigrants to the region had become impossible to resist (Kimerling 1985). 


\section{A HINT OF HISTORY}

Following the European discovery of America, the Pacific Northwest was first explored by the Spanish, who scouted the northern extremities (in what is now Oregon) of their Mexican empire in unpublicized ventures in 1542,1543, and farther north in 1603 (Kimerling 1985). The English also kept secret Sir Francis Drake's explorations in 1579, but later announced his landing and his claim of "New Albion" (a term in use in some quarters for over 200 years) for Queen Elizabeth I. Neither the English nor the Spanish took much interest in the area until the late $1700 \mathrm{~s}$ when Russian expansion down the West Coast from Alaska triggered a rash of voyages, international temper tantrums, and territorial claims. Not surprisingly, little of that pique matters today.

Two hundred years later, while the Revolutionary War was being waged on the other side of the continent, the English captain, James Cook, charted the coast from Oregon to the Arctic in 1778. After his party searched for the long-rumored passage through North America to the Atlantic, Cook sailed on to "discover" Hawaii. Ten years later, the first of a new breed, the Americans, arrived in the Northwest by sea, in an expedition captained by Robert Gray of Boston. In 1791, the British dispatched the vessel Discovery under the command of George Vancouver to survey the Northwest coast.

Early on the morning of April 28, 1792, Vancouver sighted a sail which turned out to be the Columbia Rediviva, one of the two ships in Robert Gray's venture (Morgan 1962). Joining forces, the two expeditions one American, one English -- sailed north to the Strait of Juan de Fuca; the English Vancouver party continued inland to explore the amazing web of waterways. They named many locations that remain so titled today Mount Rainier, Bellingham Bay, and the Puget Sound (Kimerling 1985).

\section{(Continued)}

\section{The Dusty Trail}

No account of the early events affecting the region would be complete without mention of the first overland exploration of the area. On November 7, 1805, the famed Lewis and Clark expedition, dispatched by Thomas Jefferson, reached the mouth of the Columbia by land
(Morgan 1962). This achievement must stand as a testament to any number of things -- the human spirit, Jefferson's vision, the friendliness of the Native Americans, and the sheer audacity and impressive human energy of the times.

Following the lead of Lewis and Clark, also moving overland, John Jacob Astor of New York expanded his American Fur Company into the region in 1810. The Stars and Stripes were unfurled over his bailiwick, Astoria, in 1811. But elsewhere the Union Jack was brandished over a scattered, diffuse "New Albion" as the Hudson Bay Company built one of the strongest, most enduring trading networks in the region. The Hudson Bay Company was headquartered at Fort Vancouver on the Columbia's northern bank in present-day Washington.

By about 1825 , the trading companies were literally beginning to settle down; the Hudson Bay Company's Chief Factor, Dr. John McLoughlin, seeing an opportunity to provision the trappers, merchants, and drifters dispersed throughout the West, took an unusual step for a trader. He pioneered an agricultural economy, encouraging retiring employees to settle locally instead of returning to their origins.

This created a patchwork of varied settlements. For example, by 1836, 30 Frenchspeaking families were listed as living on the French Prairie on the banks of the Willamette River in Oregon (Kimerling 1985). The region's population pool was unique, embracing Caucasians, Indians, and Polynesians -- often blended (there are references to Chinese as well). Records indicate an almost endless mixture of race and culture -- French-Indian, Scots-Indian, Owyhee (Hawaiian)-Indian, French-Owyhee, Iroquois-Western Indian and Negro-Indian "for a black now and then jumped ship or came with his master across the plains" (Munnick 1972).

The uniquely blended population pool did not become significant, however. Within a few decades, the Americans from the unknown land 


\section{A IIIN'I (OF IIISIOKY (continmed)}

While Vancouver remained in the Puget Sound area, Gray's party headed back South toward present-day Oregon. On May 11, 1792, Gray finally discovered the mouth of the "great stream" which although fabled as the Oregon they now named the Columbia after the Columbia Rediviva.

Cook's accomplishments had been widely publicized in 1784 and earlier accounts by crew members had also appeared. Now, Gray's and Vancouver's explorations added new interest, firing the imaginations of entrepreneurs and adventurers on both sides of the Atlantic (Kimerling 1985).

The first trader of record though probably not in fact was John Hanna, who arrived in 1785 . Subsequent voyages and accounts brought traders from every quarter - Americans, English, Austrians, Russians, French, Spanish, Portuguese. With mercantile fleets bringing sca oller furs to China via Macao and other products to places around the world, the traders established outposts throughout the region that endured well into the 19 th century.

The Northwest was not a prize - at least not in the late 18 th and early 19th centuries - but it wasn't slighted either. In many cases, for reasons lost in time, those who ventured into the region seemed reluctant to share the information. In most cases, they were ardent about what they saw - and what they felt. George Vancouver, not known for his poetry, said in 1791:

"The serenity of the climate, the innumerable pleasing landscapes, and the abundant fertility that unassisted nature puts forth, require only to be enriched by the industry of man with villages, mansions, cottages, and other buildings, to render it the most lovely country that can be inagined."

The legacy of this carly period endures today in the patchwork of place names, the inability to credit any one event or Indian tribe or other group of people to specific developments - or vice versa. There had been over 125 Indian tribes in the region, none dominant, and the same type of diversification and proliferation characterized the somewhat shallow-rooted American and European forays into the Pacific Northwest up until the 1840s.

to the East, mostly of Anglo-Saxon lineage, overwhelmed it. The great westward migration along the Oregon trail began in the 1840) bringing settlers, not traders, to the region. Incredibly, the ruts of the wagons that brought the new breed are still visible on the high desert today. The ruts, the New England place names, the scale of the first new settlements remain. But the spirit of the Northwest was already here -- the newcomers found a civilization already flourishing. They found that it was - and is -- difficult to impose one's own order on the Pacific Northwest. It already had its own, thank you very much.

Nevertheless, sheer numbers prevailed. So many Americans came and dispersed so widely over the region south of the Columbia that their mere presence overshadowed England's longstanding claims to the area. Moreover, the economy was changing -- as the Hudson Bay Company's John McLoughlin had foreseen nearly two decades earlier; this meant that England's stake in the region was dwindling about as rapidly as its share of the population. Fort Vancouver, on the Columbia, became unprofitable and was threatened by the Americans. In 1845, the Hudson Bay Company moved its one-time flourishing Northwest outpost north of the Strait of Juan de Fuca to Vancouver Island (Morison 1965).

England's declining stake in the area undoubtedly influenced Queen Victoria's foreign minister to agree to a compromise between the longstanding U.S. claim to sovereignty as far north as $54^{\circ} 40^{\prime}$ (the border of Russian Alaska) and the British counterclaim for all lands north of the Columbia. The compromise would establish a border at the 49th parallel as far west as the Puget Sound and from there to the Pacific through the Strait of Juan de Fuca. Except for minor skirmishes over the San Juan Islands in the Puget Sound, the matter was settled when the Senate ratified President Tyler's proposal to accept this offer on June 15,1846 . It took 5 months for the news of their finally-determined nationality to reach the Northwest settlements (Morison 1965). 
From 1846 onward the Pacific Northwest became part of the United States and in its quirky way followed the mainstream of U.S. development -- with somewhat less than a 5month time lag as communication and transportation steadily improved. The first sector of the region to evolve from U.S. Territory to statehood was Oregon, in 1859, then Washington and Montana (1889) followed almost immediately by Idaho (1890) (Kimerling 1985).

\section{The Light Fantastic}

By the 1880s, farms and ranches, cities and towns, mills and factories were being built throughout the region. The telegraph linked the Pacific Northwest with the rest of the nation, and its seaports -- Portland, Tacoma, and Seattle - had never lost their ties with the wider world beyond. In fact, in 1879, it was through its seaports that the Pacific Northwest found itself, not 5 months behind, but in the forefront of developments in an exciting new field: electricity.

The electric arc light first dazzled the world at Philadelphia's 1876 Centennial Exposition. Only 3 years later in 1879, the SS California equipped with six arc lights powered by the ship's engines docked in Portland. Portland by now had 40,000 residents, 10 times as many as Seattle and a goodly share of the region's 321,000 souls (Tollefson 1987). In the same year, "back East," Edison unlocked the secret of the incandescent bulb, without which electric illumination would have been no threat (except possibly for street lighting) to the gas lighting then in general use in urban areas. Arc lights were too harsh and inflexible to serve as general lighting. Edison's scheme, once he developed a substitute for the softer, flexible gas lamp, was to duplicate the gas distribution system with electricity (Tollefson 1987). A bold plan, even for the times, even for Edison!

He was not alone; particularly in the raw Northwest where lighting systems had to be built, not replaced, whose inhabitants by virtue of being in this raw land were among the boldest risk-takers on the planet. Oregon gave Edison his first commercial order for the untried incandescent system. A ship owned by the Oregon Railroad and Navigation Company, the SS Columbia, was equipped with Edison's new incandescent light and like the SS California, only a year after the first arc light had appeared, it lit the docks of Portland in July 1880. But this time something else happened. On September 4, 1880, wires from the ship were stretched ashore to the Clarendon Hotel and incandescent lights strung over Portland's First Street were illuminated by power generated on the SS Columbia (Tollefson 1987). It was a truly electrifying event; it convinced the region of the potential of Edison's invention and his scheme.

That same year, George Weidler erected a dynamo in his Portland sawmill to power an arc lamp system. Another Edison incandescent system sent to Hailey, Idaho, lit a silver smelting plant soon after the first steamship system had been built. In 1882 , Tacoma installed the Washington Territory's first generator and in $\mathbf{1 8 8 5}$ the region's first hydroelectric dam, in Spokane, powered a dynamo operating 12 arc lights. Another 1885 "first" was the region's first central system, installed to produce electricity for hundreds of bulbs, by the newly organized Seattle Electric Lighting Company (Tollefson 1987).

The expansion of the Pacific Northwest and the technical evolution of electricity coincided with nearly perfect timing. New electric lighting systems began to glow (incandescent) or glare (arc) all over the region at an incredible pace. The world's first long-distance direct current (dc) electric transmission originated in Portland (see Box) in 1889 and a year later another Portland venture demonstrated the potential for transmitting alternating current (ac). That same year a hydroelectric project at Snoqualmie Falls in Washington was one of two in the United States to test the new ac transmission methods, serving as a model for a new technology -- the 
other was at Niagara Falls (Tollefson 1987). The emergence of the trolley car -- Seattle, Tacoma, Spokane, Boise, and Portland were all establishing trolley systems as early as 1889 -. provided yet another regional impetus to construct central electrical power stations.

\section{FIRST IIGH \\ TENSION POWER LINE}

The world's first long distance high-tension power line began operation between Portland and Willamete Falls by the Willamette Falls Electric Company on

June 3, 1889

(Plaque in downtown Portland)

\section{Water, Wattage Everywhere}

Maybe it was the beaver who inspired the phenomenon; more likely it was simply putting two facts -- one old, one new -- together. The region's hunger for electric power was insatiable and it became clear that the everpresent Cascades could perhaps do more than impede transpurtation. Of course, not every community could claim a natural waterfall, but ingenuity prevailed and many dams, small by today's standards, were built. Population growth drove the development of new power resources; by 1910, after a decade of explosive growth, the population of the region reached $2,516,000$ (an eight-fold increase over the population in 1880 at the beginning of electricity's development) and Washington surpassed Oregon as the region's most populous state.

As the utility industry expanded further and faster than anyone might have imagined (except perhaps Edison) it became more and more difficult for the multitude of small companies to keep pace with the scale of the effort required -- they were pressed beyond their limit by both technology and capital requirements. Engineers gave way to investment bankers and electric holding companies began to dominate the industry by controlling transmission facilities. Alternatively, if a small local producer did not merge with a holding company, the municipality took over the local electric systems. Both private and public power interests in the Pacific Northwest grew larger -and the rift between them grew wider -throughout the early 1900 s.

World War I sharply escalated the national need for power and put the federal government into the power business, building large generating plants in the South and East. This led to proposals, as early as 1918 , that a huge federal dam -- Grand Coulee was already its name -- ought to be built to harness the mighty Columbia (Tollefson 1987). Although this task was too monumental to be seriously considered at the time, increasingly larger hydroelectric projects were being planned and built in the region. More was learned about interconnecting power resources, leading to larger and more efficient networks. In 1928, private power interests started work on the Rock Island dam, the first to be built on the Columbia River. When the dam was begun, private power was "riding high" in the Pacific Northwest as elsewhere. By the time the Rock Island undertaking was completed in 1932, the private power industry -- like the entire country - was in the grips of the Great Depression.

\section{(Public) Power to the People}

In 1932, Franklin Delano Roosevelt (who was then campaigning for the presidency) made power an issue, urging strict control of interstate power. Speculation in utility stocks had certainly contributed to the stock market crash. Beyond this, he promised a Portland audience that the next great public power project in the United States would be on the Columbia River. It was not campaign rhetoric, Roosevelt quickly made good on his promise. During the summer of 1933 he made the decision to build the Grand Coulee and Bonneville dams (Tollefson 1987). 
"I always believe in the old saying of more power to you."

-Roosevelt at the Bonneville Dam Construction Site

August 3, 1934

The decision to build the dams was based on creating jobs as much as for anything else. When completed, however, neither the river nor the power picture in the Pacific Northwest would ever again be the sanie. The ultimate result would be the nation's most productive hydropower system, a cornerstone of the region's economy, and a system that would turn deserts into cropland and spur industrial growth (NWPPC 1986). In a whirlwind tour of the dam sites in August 1934, Roosevelt was greeted wildly -- the workers at the Bonneville Dam site saluted him with their steam shovels. Perhaps somewhat overcome, he was downright giddy about his views on power (see Box) (Norwood 1981).

When created on August 20,1937, the "Bonneville Project" was a stop-gap measure, designed to deal only with the power available from the imminent completion of the Bonneville Dam. Congress had failed to reach consensus on the scope of the new federal undertaking; the issues were thorny and controversial, technological and political. Interestingly, they tended to focus on transmission -- the Northwest's forte. Transmission developments and the increased efficiency of large power grids had provided the technical and economic basis for the growth of the large holding companies and the extent to which the federal government ought to participate was the primary question. By 1937, the U.S. government was an "old hand" in the dam business -- it was less clear that it belonged or wanted to be in the transmission business.

Without resolution of the transmission issue, however, the power generated at the new dams would be meaningless. Customers were waiting. Washington State had solidly endorsed the concept of public utility districts (PUDs) while rejecting a proposal to construct stateowned transmission lines. This forced Congress to make a choice -- federal or private transmission. There were other complications. The U.S. Bureau of Reclamation was building Grand Coulee and the U.S. Army Corps of Engineers was building the Bonneville Dam. A monumental report published in 1936, developed in 1935 by the Pacific Northwest Regional Planning Commission (PNWRPC), outlined five alternatives (Norwood 1981):

- Market power through both constructing agencies.

- Select one existing agency to generate and market power.

- Create a new agency to generate and market power.

- Create a Columbia Valley Authority (CVA).

- Establish a federal power corporation to generate and market power.

The Bonneville Project Act created an agency that was none of these and dealt only with the power from the Bonneville Dam. The Corps of Engineers would generate the power, but the new agency would be responsible for transmission and, ultimately, marketing. It was a temporary solution until an authority to be called the CVA, patterned after the Tennessee Valley Authority (TVA), could be established.

\section{The Reins of Power}

Throughout the next two decades, the CVA legislation repeatedly suffered defeat in Congress, and the Bonneville Project (renamed the Bonneville Power Administration in 1938) emerged as the "only game in town." In 1940, rather than have two federal agencies involved in transmission, Executive Order 8526 established the Bonneville Power Administration as the responsible agency for transmitting the power from the Grand Coulee and gave it the 
authority to negotiate contracts for the sale of its power (Tollefson 1987). Not unlike the holding companies of the 1920 s, Bonneville was holding the reins.

The initial authority granted Bonneville to construct transmission facilities was the key to subsequent developments in the Pacific Northwest. By the early 1940s, high-voltage transmission lines from the dams to a mammoth Bonneville sub-station in Vancouver, Washington, were in place. World War II changed everything. What was thought to be an incredible surplus of power turned out to be the right resource, in the right place, at the right time as Bonneville provided power for new aluminum smelting plants along the Columbia, for the shipbuilding effort, and for the top secret Manhattan Project at Hanford, Washington.

The availability of relatively vast amounts of power brought new industries to the Pacific Northwest in a time of crisis and sparked industrial growth beyond all expectations. With one of the world's most powerful transmission systems in place, Bonneville gained Congressional authority to "wheel" power, using its facilities to transfer power for others, virtually ensuring Bonneville a central role in the Pacific Northwest power picture regardless of whose power it was. The achievements of the next 40 years would dwarf anything that had gone before. In the 1960s and 1970s, over 10,000 added megawatts of power nearly quadrupled the power available (NWPPC 1991) - not bad for a temporary agency.

\section{Summing Up}

A land of paradox then and now. Isolated yet curiously cosmopolitan, sturdy and practical yet capable of being driven by visions.

Fragmented yet strangely consistent, united, cooperative (Kimerling 1985):

There is an intangible cohesion to the region, an underlying characteristic that we recognize as the Pacific Northwest. Despite our differences, the gulf between us and everyone else is sufficiently great that we draw together. We share concerns even if we do not agree about solutions... Our concerns mean little to those outside the region and this relative lack of interest draws us together, like members of a family.

The land and history are richer than one might suppose. They have given rise to a distinct breed of people at once conservative yet highly individualistic. Friendly, yet reserved. Cooperative, yet cautious. Practical, yet ingenious. The land, the waters, and the people combined to create a unique power system and a unique society to harness and manage it. By the late 1970s, it was also a system that was outgrowing its resources and its charter. 


\section{CHAPTER 2: THE BACKGROUND -- A New Order}

Any notion that the Pacific Northwest is simply an area with cheap power, making lavish use of energy as a result of vast hydropower resources, is only partially true. While the region has the most extensive hydropower facilities in the nation with relatively low power rates and extensive use of electric energy as a result, the idea that the use of this energy in the Northwest is therefore undisciplined is not the case. How did the vast resources and the disciplined use of energy -somewhat a paradox, after all - come to be?

After World War II, when wartime production ceased, the region was glutted with power. However, many of the wartime workers, like those who had come before, chose to remain in the region despite economic uncertainty. With a growing and resourceful population, the energy reserves were quickly reduced to a mere surplus that was soon eroded. Growth in power demand during the 1950 s and 1960s was spurred by industrial growth, the extension of electricity into every nook and cranny of the region, and increased per-capita consumption of electric energy. The consumption of electricity in the region grew to levels nearly double the national average, as shown in Table 2.1 (NWPPC 1986).

For three decades -- the 1950s, 1960s, and 1970 s -- the region's energy resources continued to expand, in herculean, creative, often dramatic, and sometimes imprudent ways. By the mid-1970s, as the nation faced its first peacetime energy crisis triggered by the manipulation of world oil prices and supplies, it was time to take stock, establish a more unified power system, and plan for the future.

Just as the region had pioneered the use of electric power, the Pacific Northwest Electric Power Planning and Conservation Act of 1980 (referenced in this section as the Act) that resulted from this stock-taking ensured that the
Pacific Northwest would remain in the forefront of energy development -- no longer by building massive dams, incredible transmission facilities, or international alliances, but by learning to use these singular resources more efficiently and working together to achieve rather sophisticated new goals.

\section{Creating New Resources}

Broadly, the late 1940 s and 1950 s simply played out the script that had been written in the 1930 s, building more federal dams on the Columbia and Snake Rivers to carry out Roosevelt's original vision. These efforts continued into the 1970 s because of their scale and complexity, However, the key developments in the 1960s and 1970s were projects to increase storage, enhance efficiency, and expand markets for federal hydropower (Tollefson 1987).

More Dams - In 1952, the advent of a Republican administration, more or less opposed to the expansion of the government's role in the power business, did little to change the fact of continued dam-building on the Snake and the Columbia Rivers. What changed was who built them. Many projects that were originally planned as Corps of Engineer or Bureau of Reclamation projects were "privatized." The problem was that private power companies had no interest in the nonpower aspects of the larger dams -- their irrigation, navigation, and flood control functions -- and the dams weren't getting built (Tollefson 1987).

By the second Republican administration the government was back in the dam business -- a compromise had been reached whereby mainstem dams would remain the responsibility of the federal agencies, and private interests would be encouraged to build dams on tributary rivers. It was during this period that Bonneville 
TABLE 2.1 - Per Capita Use of Electricity (kilowatt-hours per person)

\begin{tabular}{||l|c|c|}
\hline Year & $\begin{array}{c}\text { Pacific } \\
\text { Northwest }\end{array}$ & $\begin{array}{c}\text { United } \\
\text { States }\end{array}$ \\
\hline 1960 & 8,930 & 3,810 \\
\hline 1970 & 14,790 & 6,800 \\
\hline 1980 & 17,230 & 9,230 \\
\hline 1982 & 16,330 & 9,000 \\
\hline \hline Source: NWPPC 1986 & & \\
\hline
\end{tabular}

gained the authority to "wheel" power from these varied projects -- President Eisenhower signed the legislation on August 26, 1957. In the interim, Idaho Power had built dams on the Snake River and a series of dams had been scheduled to be built "privately" on the main stem of the Columbia.

"But it remained for me to come to Oregon to see the biggest dam the Army Engineers have ever built."

-Vice President Richard Nixon at the dedication of The Dalles Dam.

October 10, 1959

But the Columbia was a different story. The idea of public power had become so ingrained in the state of Washington that the federal inertia simply coerced the PUDs on the Columbia into assuming the responsibility for building dams. The mid-Columbia PUDs set up consortiums of potential users, including investor-owned utilities (IOUs), who financed the dam construction effort in exchange for 50year contracts for an agreed-upon percentage of the power the dams would produce (Tollefson 1987).

The push for more private power had the unwanted effect of strengthening the role played by public power in the Pacific Northwest.
Besides forcing the mid-Columbia PUDs into a central role in dam construction, regional uncertainty and concerns about federal actions led to the formation of the Washington Public Power Supply System (WPPSS) in January 1957 (Norwood 1981). One concern was that the region could no longer rely upon the federal government to keep pace with the region's growing need for power. Another concern was an oft-rumored scheme to privatize the Tennessee Valley Authority. Could Bonneville be far behind? The public power interests in the region claimed that WPPSS was, in part, established to take over Bonneville if, indeed, the government decided to divest itself of its power functions and agencies (Tollefson 1987).

More Storage - Most of the dams constructed during this period were run-of-river dams, with no capacity for storage; they only compounded the problem. Water is the raw stuff of power in the Pacific Northwest and its availability was the chief factor limiting the amount of power the system could reliably produce. In the spring, much water (and hence power) was lost over the spillways while in the fall and winter, reduced volume and stream flow limited the amount of power available. Because the amount of run-off varied, Bonseville could only guarantee "firm" power up to the amount of stored supplies in the lowest "water year." If storage could be increased, stream flows could 
"Great storage works are necessary to equalize the flow of streams and to save the nood waters."

-Theodore Roosevelt

Message to Congress

December 3, 1901

be stabilized throughout the year and firm power commitments could be increased.

It was not a new idea (see Box). As early as 1948 , plans were afoot to significantly increase the storage capacity of the Columbia River system by building dams and storage facilities far upriver - in Canada. In the late 1950s, plans were drawn up for Canada to build three storage dams in British Columbia while the United States would build one - in Libby, Montana. After potential benefits and their apportionment had been studied, the Canadian and U.S. heads of state signed the Columbia River Treaty on January 17, 1961, just days before the inauguration of President John F. Kennedy (Tollefson 1987).

Under the terms of the treaty, Canada would be entitled to half the increased power benefits resulting from the improved stream flow control at each of the Columbia River dams in the United States. Problems ranged all the way from how to achieve these benefits to how to market them. Canada had no immediate need for this power and neither did the Pacific Northwest. Five basic ideas emerged from treaty negotiations and served as a catalyst for other Bonneville actions simultaneously underway (Tollefson 1987):

- The downstream benefits of Canadian storage, shared equally by the United States and Canada, must be sold in the United States to provide the money to build the dams in Canada.
- The Columbia Storage Power Exchange (CSPE) would be the means by which utilities would purchase the Canadian share of the downstream benefits (the Canadian Entitlement).

- Utilities operating dams on the Columbia River would do so in a manner that would maximize benefits by coordinating operations as if the dams were all operated by a single utility.

- Northwest utilities would have first call on all federal power generated in the region.

- An Intertie, composed of both ac and dc transmission lines, would be constructed to connect the Pacific Northwest and the Southwest to facilitate the sale of the Canadian Entitlement, purchased by the CSPE, to Southwest utilities.

The Coordination Agreement - In 1961, Bonneville began negotiations toward a coordination agreement for operation of the region's hydroelectric projects based on the "single utility concept," treating the system as though it had only one owner (Norwood 1981). Cooperation wasn't a new idea either; regional utilities had informally cooperated for almost 20 years. At the policy level, utility officials had met since 1946 as the Tacoma Conference, which later became the Pacific Northwest Utilities Conference Committee (PNUCC).

The benefits of coordination would have been sought in any case, but the needs of the Columbia River Treaty increased the motivation and accelerated the pace for the complex negotiations. After reaching understanding on three interim agreements, the last covering a 10-year period, negotiations went into high gear in 1964 to attempt a 39-year agreement -- to cover the period for which the Canadian Entitlement would be sold to the CSPE. On September 15, 1964, the Pacific Northwest Coordination Agreement (PNCA) was signed; the PNCA will expire June 30, 2003. 


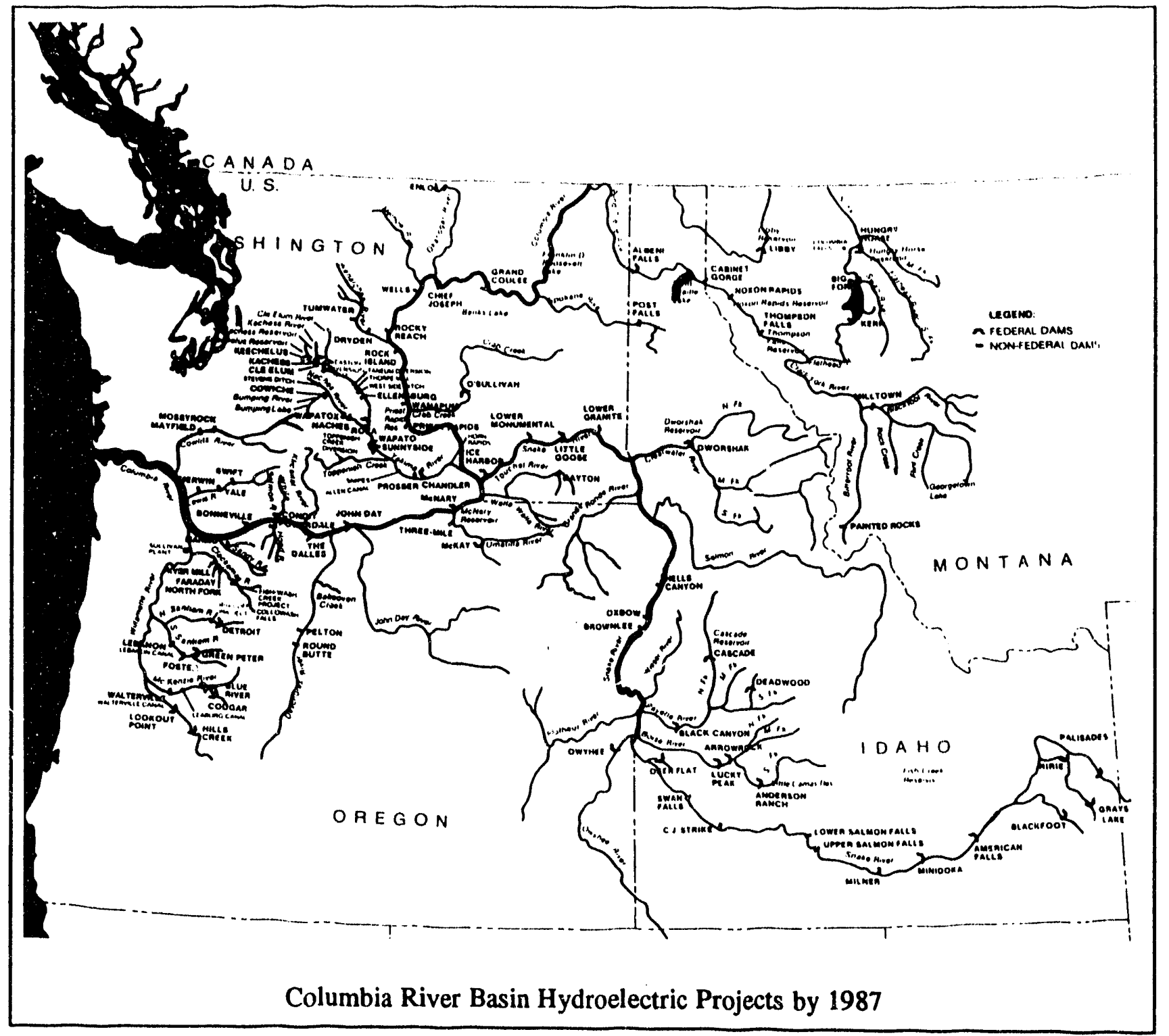

The PNCA dialogues demonstrated that Bonneville was willing to negotiate and open to compromise. It helped to encourage more regional participation in Bonneville operating decisions. It also established that the Agency would play a more active role in helping to determine and develop the region's future power resources (Norwood 1981).

The Intertie - Also in connection with the Treaty, Bonneville revisited its long-standing plans for an Intertie with California. The concept of linking the Pacific Northwest, including British Columbia, with California as far south as Los Angeles had been broached as early as 1919 (Norwood 1981). It had also been controversial nearly the entire time. Nevertheless, an interconnection would undoubtedly have been built at some point. However, the need to find a market for the Canadian share of the increased power production was a spur to immediate action. California had long been wooed as a potential customer for the vast amounts of nonfirm power that were sometimes available; but, up to 
this point in the 1960 s, California had insisted on firm power commitments as well.

Bonneville was unable to make commitments for firm power primarily because there was little available at the time. Even if there were, the issues involved in selling low-cost federal power outside the region, to fatten the region's coffers at the expense (indirectly) of U.S. taxpayers would have been difficult to resolve. Selling surplus power that would otherwise go to waste was one thing, selling firm power was likely to be much more controversial. The availability of what had come to be known as the Canadian Entitlement proviáed Bonneville the ability to "sweeten the pot" with firm power without reducing its Pacific Northwest firm power commitments by 1 kilowatt!

When Bonneville first studied the economics and technology of dc transmission in the late 1930s, it was found to be an unieasible alterrative. Since that time, Swedish developments had proved that dc systems were an efficient means of moving large amounts of power. After intense study, Bonneville opted for the dc approach. On August 31, 1964, nresident Johnson signed authorizations to construct two 500-kV ac lines and two $800 \mathrm{kV}$ $\mathrm{dc}$ lines. Utilities built the California ac lines and Bonneville built the $\mathrm{dc}$ lines and one ac line in Oregon. Bonneville and Portland General Electric (an investor-owned utility) built the second Oregon ac line.

\section{The Hydro-Thermal Power Program}

It wasn't enough. In spite of the incredible effort - treaties, finely wrought coordination agreements, new dc technology - the Pacific Northwest's resources were merely keeping pace with load growth. Bonneville had solught and obtained more water, more markets, and more efficiency, and had worked with the region in a way once thought not possible. It had developed creative ways to market the peculiar resource - plentiful 1 month, in short supply the next - via norifirm power contiacts with direct service industries (DSIs) - mostly the aluminum producers on the banks of the Columbia in Washington. But growth was phenumenal. Throughout the 1960s and 1970s, electric load growth averaged $5.2 \%$ per year; 10,000 average megawatts of new resources were added during this period (NWPPC 1991).

After a few false starts, the region embarked on an approach to develop a combined hydrothermal power operation. Bonneville called for joint planning and launched the Joint Power Planning Council (JPPC) on November 23, 1966 (Tollefson 1987). The JPPC developed a 20-year plan, refined for program purposes to 10-year programs of specific plants and specific sponsors. The first 10-year Hydro-Thermal Power Program (Phase I) was approved by President Nixon on October 27, 1969 (Norwood 1981). It called for seven large thermal plants (see Box - Hydro-Thermal Power Program) to be constructed by private power and WPPSS.

\section{HYDRO-THERMAL POWER PROGRAM Phase I Thermal Plants}

Jim Bridger/Wyoming (Coal)

Trojan/Oregon (Nuclear)

Centralia/Washington (Coal)

WPPSS/Washington (Nuclear)

WPPSS/Washington (Nuclear)

WPPSS/Washington (Nuclear)

Bonneville had no authority to acquire generating resources. To facilitate the development of the Phase I projects a procedure called net-billing was proposed. Bonneville would pay for project capability purchased by its preference customers by offsetting their financial obligation in specific projects against their monthly power bills. Adverse rulings by the Internal Revenue Service and high costs ended this phase of the hydro-thermal program in 1973 (NWPPC 1991). The three coal-fired thermal plants were nevertheless built along with Trojan, the private power nuclear facility. 


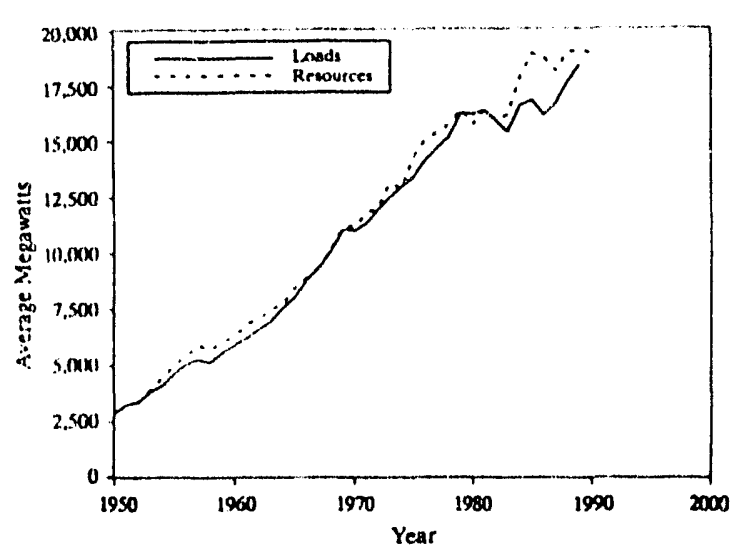

Firm Electricity Loads and Resources

These facilities are listed among the generating resources in the region but how they were built is unclear (NWPPC 1991).

The WPPSS nuclear plants are another story. Phase II of the Hydro-Thermal Power Program called for utilities to take power from their own shares of the generating plants while Bonneville provided transmission and "shaping" of the generation to fit power loads. WPPSS nuclear plants 4 and 5 were the primary facilities associated with this phase. Environmentalists took the issue to court; the Natural Resources Defense Council (NRDC) and the Sierra Club charged that Bonneville had failed to file an environmental impact statement (EIS) regarding its role as a regional energy supplier in Phase II. Another lawsuit filed by the Port of Astoria charged that Bonneville had failed to file an EIS for a contract it had signed to supply a new regional aluminum producer (Tollefson 1987).

Bonneville completed the six-volume, 3,100page EIS draft in August 1977. The EIS contained a conservation study that concluded the region could meet a substantial part of its load growth through conservation. At this time, Bonneville took its first steps toward conservation, forming a task force to begin work on energy-saving measures and their implementation (Tollefson 1987).

In the meantime, Bonneville remained tied to WPPSS' construction of nuclear plants 1, 2, and 3 through the net-billing arrangement. Although it had the power to approve the WPPSS construction budget as a whole, Bonneville had no financial control over specific aspects of the project. By 1978, the cost overruns were staggering, yet Bonneville had no contractual power to change the situation.

\section{New Attitudes, New Approaches}

Nothing was working. On top of everything else, 1977 was one of the lowest water years on record. In the fall of 1976, Bonneville was forced to cut energy supplies to its direct service industry clients and could no longer supply "secondary" energy supplies to the investor-owned utilities. Economic consequences were sudden; in 3 months the aluminum smelters had cut back production by $20 \%$ and laid off 600 workers. Since 1973, private utility rates had soared after investorowned utilities had been denied firm power contracts (Tollefson 1987).

By now, the nation had experienced the oil crisis in the early 1970s and energy consciousness was increasing. Following the work of its task force on conservation, Bonneville had set up an Office of Conservation. By 1979, Bonneville was casting the major accomplishments of the early 1970s in another light, describing them as, at heart, conservation efforts (Norwood 1981). The increased capacity of the dams achieved through more uniform stream flows and the efficiency gains realized through coordinated power production were certainly a more prudent, efficient use of energy.

Simply jumping on the conservation bandwagon wasn't going to solve the problems. It was time, regional leaders were arguing, to take a long hard look at the energy situation in 
the Pacific Northwest, impose some order on it, and develop more coordinated methods to deal with the region's long-term power development. After all, Bonneville was still only a temporary agency. And some of the problems were undoubtedly due to uncertainty, inside and outside Bonneville and inside and outside the region, about what Bonneville's role and authority ought to be. There was only one place to turn for that kind of help -- the U.S. Congress.' After all, power in the Pacific Northwest was...

\section{A Congressional Afrair}

In recognition of the growing need for a national energy policy and a more coordinated approach to energy matters, the U.S. Department of Energy (DOE) was established by the Carter administration. On October 1, 1977, Bonneville was taken from its "temporary" assignment within the U.S. Department of the Interior -- where it had been for 40 years - and placed within the DOE.

Bonneville's organizational identity was now more clear, but little else was certain. The focus had now shifted to the "other" Washington -- Washington D. C. -- where several approaches to the Pacific Northwest energy situation were being reviewed. There were at least three attempts at comprehensive legislation over more than a 3-year period before the final version was adopted:

- The first bill was drafted by the PNUCC and presented to the Pacific Northwest Congressional delegation in May 1977 (Tollefson 1987). It would permit Bonneville to purchase power, thus backing up financing for new resources. However, utilities had the final decision on which plants would be added to the federal power supply. Public power interests were concerned that this approach could damage their preference rights -- their first call on federal power. The effort suffocated over the next 15 months, officially dying on August 14, 1978 (Tollefson 1987).
- The second approach was triggered by an offer from Bonneville's direct service industry customers to consider higher rates in exchange for long-term, 20-year contracts. With these funds available, it was proposed that Bonneville could set up "exchange" contracts with utilities allowing them to buy federal power to serve their residential and small farm customers at cost. Bonneville would purchase an equivalent amount of power at the utility's higher average system cost. At the time this revolutionary plan was broached, the idea was that Bonneville could finance the cost differential with the increased direct service industry revenues. However, the estimated costs far outweighed the financial ability of the direct service industries (chiefly the aluminum industry) to pay and this legislation foundered although the exchange provision had strong appeal (Tollefson 1987).

- The third approach gave top priority to the acquisition of cost-effective conservation, followed by renewable resources.

Bonneville could acquire power from conventional plants only after these resources were exhausted and/or not costeffective. The region's governors offered an amendment to include a regional power council. Proposed legislation to mitigate the effects of power projects on the region's fisheries was merged with the power-related provisions into a single piece of legislation. Concerns and disagreements over Bonneville's role on the proposed council and questions about the constitutionality of an arrangement that could result in state control over a federal agency prevented this legislation from being passed during the 1979 session (Tollefson 1987).

In 1980, the U.S. House of Representatives began the fourth and final attempt to draft comprehensive regional power legislation. The final Pacific Northwest Electric Power Planning and Conservation Act was an amalgamation of the best provisions of each of the earlier 
attempts. It dealt constructively with the allt(oo-familiar issues that had triggered the crisis and the not-so-nice, new issues that had been raised while attempting to solve the problem. The region needed a means to accomplish the following (NWPPC 1991) accomplished the following:

- Accelerate development of urgently needed new resources.

- Advocate and foster conservation as an alternative to thermal plants.

- Resolve the competing interests of public power and investor-owned utilities for access to federal power -- the "preference clause" issue.

- Lower the region's investor-owned utility rates which were soaring due to the high cost thermal resources these utilities had to acquire because of their inability to purchase federal power.

- Avoid the extremely difficult and controversial process of allocating limited power supplies if Bonneville can no longer meet customer loads.

- Ensure the future of the direct service industries. Based on 1980 projections, under current law, the direct service industries would have to be sold to public utilities when their contracts expired in the 1980s.

- Institute remedial measures to halt the decline of the Columbia River salmon and steelhead runs.

The Act was passed by the House of Representatives on November 17, 1980, passed by the Senate on November 19,1980, and signed by President Carter on December 5 , 1980. The Act (NWPPC 1991) accomplished the following:

- Expanded Bonneville's role, allowing it to acquire resources, develop conservation programs, and help to restore fish and wildlife.
- Provided a mechanism for Bonneville to acquire the power generated by a power plant and pay the costs of building and operating it; this "guaranteed purchase" would provide utilities better access to financial markets and spread the development risks across the region.

- Incorporated the exchange provisions of the earlier legislation, thus ensuring that all residents of the region would have access to the benefits of public power. While preserving the preference protection sought by public utilities, it gave private utilities access to the federal system to heip even out the soaring costs of new thermal power.

- Authorized Bonneville to commit to longterm contracts with the direct service industries; the industries agreed to absorb a large portion of the costs of the exchange program.

\section{A New Cast Member}

A new planning body, the Northwest Power Planning Council (referred to in this report as the Council or NWPPC), was created under the terms of the Act. As it defined itself, the Council is an interstate compact agency made up of eight members, two each from the states of Idaho, Montana, Oregon, and Washington. All members are appointed by their respective governors and confirmed by their respective legislatures; the Council is not an agency of the U.S. government (NWPPC 1983).

As required by the Act, the Council produced the first Northwest Conservation and Electric Power Plan 2 years later on April 27. 1983. It noted the reversal in energy economics from "the more you build the less it costs" to "the more you build, the more it costs" (NWPPC 1983). At the time the region was still reeling from the harsh lessons learned from Phase I and Phase II of the HydroThermal Power Program. 
At the time the Council's 1983 power plan was released, the region's utilities had been "caught in a whipsaw" (NWPPC 1983). Growth projections had been based on historical patterns but those levels of growth did not materialize, thus decreasing utility revenues. At the same time, cost requirements to construct new thermal facilities skyrocketed and the delays mushroomed. One of the key principles stressed in the initial power plan was that one of the region's major challenges was "to reduce the probability and consequences of being wrong" (NWPPC 1983). The timing was unintentional, but the significance and wisdom of the Council's approach was underscored by the impending failure of WPPSS. Court actions later that year permitted the agency to default and litigation dragged on for years.

The Council presented a range of forecast and flexible planning scenarios that could accommodate future changes in electric energy supply and demand in a timely manner. As the law required, the plan included "a demand forecast of at least 20 years" (NWPPC 1983). The range of forecasts and estimated costs developed by the Council are shown in Table 2.2. These forecasts did not include the potential impact of conservation efforts but did encompass the effects of improved efficiency and more stringent code and other regulations.

Forecasts were developed for four energyuse sectors - residential, commercial, industrial, and irrigation.

The power plan included a schedule and specific actions to be taken over the next 2 years. The plan developed option plans and outlined ways to make resource acquisition more flexible and more timely. Conservation was, not surprisingly, the resource most highlighted throughout the plan. Not only was it mandated by the Act, it was also new and unfamiliar. Beyond that, it had features that were particularly attractive under the circumstances -- relatively low cost, flexibility, short lead times, minimal environmental impact, compatible with existing system, etc.

\section{Implementing the Plan}

The plan, of course, was no surprise to Bonneville or to the other organizations and associations involved with electric power in the Northwest. Their number is legion (see Box -A Heartier Alphabet Soup). A key feature of the Act and the planning process resulting from it was that decisions were made in an open, public manner. The Council viewed an important aspect of its role as providing "a new public forum for making decisions about our energy future" (NWPPC 1983). By the time the plan was completed, everyone had participated in the planning process.

\section{A HEARTIER ALPHABET SOUP}

Carrying out the various legislative mandates for marketing federal power throughout the region has been a growing effort over the years and has involved an impressive roster of federal, state, and local agencies. In 1980, the Northwest Power Planning Council was added to this array of technicians and bureaucrats and some of the most sophisticated energy planners in the world -- inside and outside the region - began to work on issues surrounding the Pacific Northwest's future energy resources and usage. The region's power planning involves a complex mosaic of authority, perspective, interest, and skills:

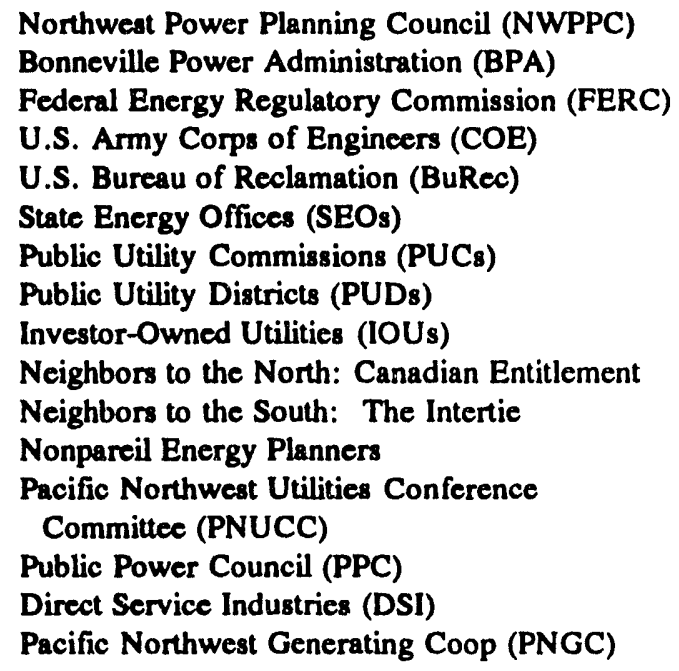


TABLE 2.2 - Forecast of Demand for Electricity and Price Projections

\begin{tabular}{|l|c|c|c|c||}
\hline \multicolumn{1}{|c|}{$\begin{array}{c}\text { Growth } \\
\text { Forecast }\end{array}$} & \multicolumn{2}{|c|}{$\begin{array}{c}\text { Demand } \\
\text { laverage megawatts) }\end{array}$} & $\begin{array}{c}\text { Average } \\
\text { Annual } \\
\text { Demand } \\
\text { Growth } \\
1981-2002(\%)\end{array}$ & $\begin{array}{c}\text { Increase in } \\
\text { Average Retail } \\
\text { Prices Adjusted } \\
\text { for Inflation } \\
1981-2002(\%)\end{array}$ \\
\cline { 2 - 5 } & 1981 & 2002 & 2.5 & 80 \\
\hline High & 15,524 & 26,245 & 2.1 & 50 \\
\hline Medium-High & 15,524 & 23,797 & 1.5 & 25 \\
\hline Medium-Low & 15,524 & 21,301 & 0.7 & 5 \\
\hline Low & 15,524 & 17,834 & & \\
\hline \hline Source: NWPPC 1983 &
\end{tabular}

\section{The Council's Plan and Building Standards}

In its 1983 power plan, the Council issued Model Conservation Standards (MCS) to serve as performance goals for the construction of energy-efficient new homes (NWPPC 1983). At the time, the plan relied heavily on the actions of state and local governments to adopt and enforce the MCS and called on Bonneville to provide incentives, training, and technical assistance.

These provisions did not affect the region's manufactured housing because these homeswere not built to local codes. Instead, they were built to a preemptive federal standard -- which included an energy standard -- enforced by the U.S. Department of Housing and Urban Development (HUD). This standard was called the Federal Manufactured Housing Construction and Safety Standard (FMHCSS) and manufactured homes were commonly called "HUD code" homes.

The 1983 plan called for Bonneville to assist HUD in developing and adopting a stronger standard, but little else. Over the next few years, Bonneville would do much more, beginning with a detailed study of the energysavings potential of these homes, testing and demonstrating their energy-saving performance, and participating in the development of a regional program to make all manufactured homes energy efficient, even beyond the MCS.

********a

One of the greatest legacies of the 1960s and 1970s was demonstrating the value of dialogue. Without dialogue the major advances -- the Canadian Treaty, the Intertie, the PNCA -would never have materialized. With more dialogue, perhaps the harsh lessons of the Hydro-Thermal Power Program could have been avoided. These events certainly bore on the development of the manufactured housing project over the next few years -- who was involved and how they participated. The region had learned the high cost of failure and the high cost of silence -- and perhaps that they were related. 


\section{CHAPTER 3: MANUFACTURED HOUSING - A Timely, Technical Stimulus}

The initial investigations that would evolve into the manufactured housing project were launched at a highly appropriate and opportune time. A study to assess the potential energy savings of the region's existing manufactured homes was initiated in June 1983 by the Technical Support Branch within Bonneville's expanding Office of Conservation. Up until this time, there was nothing unusual about the branch proposing and undertaking such a technical study. But this was a period of transition; before the year was out, Bonneville's conservation projects and priorities would be determined by regional planning. It is interesting to speculate that if Bonneville had not initiated its manufactured housing investigations at this precise point in time, the project to explore the conservation potential of manufactured housing might never have been introduced and developed.

In June 1983, Bonneville's early independent conservation efforts had not yet given way to the broader, regional approach mandated by the Act. In just a few months, from late 1983 onward, Bonneville's conservation activities would follow the action plan established in the first (1983) Northwest Conservation and Electric Power Plan (NWPPC 1983). In the environment that eventually would be established, Bonneville would not be expected to initiate studies unilaterally. Bonneville's Technical Support Branch would be charged only with providing technical support and assistance to Bonneville's new program managers who, in 1983, had not yet begun to design the conservation programs to execute the goals established in the 1983 plan.

Bonneville undertook its initial study because certain utility customers had voiced strong interest in including manufactured homes in the conservation programs already underway in their service territories. These discussions had taken place before the plan was complete.
Once completed, the Council's action plan would have discouraged, if not prevented, launching the initial study on two counts (NWPPC 1983).

First, the Council minimized and discouraged continuing the current conservation efforts, which focused on weatherization programs (retrofit of existing residential buildings) because the region presently enjoyed a power surplus. The Council emphasized that these savings could be acquired at any time in the future.

Second, the Council had omitted manufactured housing from new residential programs under consideration. These homes were built to federal energy standards which neither state nor local jurisdictions could preempt. In the Council's view, the best course of action was to attempt to influence a change in the Federal Manufactured Home Construction and Safety Standards administered by HUD.

\section{First Steps in a New Direction}

The Act did not "invent" conservation in the Pacific Northwest -- in fact it gave voice to strong forces and a heritage already operating in the region. Although lacking the direction and cohesiveness that the Council's planning effort would ultimately provide, Bonneville and its customer utilities had embarked on energysaving programs as early as the mid-1970s. Bonneville's emphasis on conservation was given further impetus when it was made part of the DOE in 1977, by virtue of both DOE's mandate and the tenor of the times.

Well before the passage of the Act, environmental groups and events had forced an incredible change in the region's consciousness and Bonneville's actions (Tollefson 1987). This was no small task; historically, Bonneville's 
efforts had been directed toward expansion. When the Bonneville Project was launched to market the power from the Bonneville and Grand Coulee dams, the region was virtually flooded with an incredible hydropower surplus. Not surprisingly, the innate ethic developed by Bonneville was to make full use of regional hydropower resources and to market electric power with almost missionary zeal.

Within Bonneville, the ongoing challenge had been to develop) transmission facilities and customers to distribute the power of the rivers tamed by the federal dams -- ever-expanding, ever-technical. But this began to change as early as 1972, when Bonneville established its Office of Conservation (Norwood 1981). In the mid-1970s, when the Hydro-Thermal Power Plan faltered and the region suffered the worst drought year (1977) in its history, real impetus was added to the growing support for energy conservation (Tollefson 1987). These events affected the course of legislative developments in Congress and buttressed Bonneville's growing conservation efforts and commitment.

In the early 1980s, after the passage of the Act, the Council was yet to come "on line" and the region's first power plan was still in development. Even so, Bonneville was studying promising areas of conservation opportunity based on its previous experience and on input from its utility customers. At the time that the manufactured housing project was launched, the Technical Support Branch was studying several promising avenues of conservation and/or renewable resources. Among them were the following:

- Small Wind Energy Conversion Systems

- Irrigated Agriculture Pilot Program

- Solar Domestic Hot Water Pilot Program

- Solar Water Heating Workshops

- Energy-Efficient Home Pilot Program

- Solar Home Builders Program II (Spokane)

- Commercial Audit Program.
The Weatherization (Retrofit) Effort

At this time, the major conservation effort underway at Bonneville was the development of regionwide weatherization programs to upgrade (retrofit) existing homes (see Box, Bonneville's 1983 Conservation Programs). In 1983, something akin to "weatherization fever" had taken hold and Bonneville's primary conservation investment, its major ongoing program -- bar none -- was the Residential Weatherization Program. It was true both ways -- residential weatherization was the biggest program in 1983 and 1983 was the biggest year historically for such investment. The 1983 outlay dwarfs any amount that Bonneville spent before or since for comparable effort.

\section{BONNEVILLE'S 1983 CONSERVATION PROGRAMS'}

A Summary (\$ millions/dollars)

Residential Weatherization

Water Heater Wrap

$\$ 127.35$

Shower Flow Restrictor

Street/Area Lighting Efficiency

27.27

Commercial Lighting/Water Heating

Institutional Buildings

.94

1.59

Designed along the lines of similar programs administered by utilities across the country in the energy-conscious years of the late 1970s, Bonneville's Res-Wes program, as it was called, differed primarily in approach. Bonneville was committed to developing high program standards so that retrofit energy conservation measures (ECMs) would be more effective, application techniques more stringent and consistent, and energy savings more quantifiable, more consistent, and more durable over time.

The weatherization programs in the Pacific Northwest and elsewhere concentrated on the more familiar, easier to work with, site-built homes. This was the case in 1983 even though manufactured homes accounted for a significant 
percentage of local housing stock in some areas of the region. Moreover, the effect of manufactured homes on utility loads was often more substantial than their raw share of the housing market percentages might indicate because the majority of them were electrically heated.

\section{HOOD RIVER-THE ULTIMATE WEATHERIZATION PROJECT}

One of the most impressive projects launched in early 1983, at about the same time the manufactured housing study was initiated, was the Hood River Conservation Project. Proposed by the Natural Resources Defense Council, the project was sponsored by Bonneville and administered by the Pacilic Power \& Light Company with the cooperution of the Hood River Electric Cooperative. At a cost of $\$ 14.4$ million, "super-weatherization measures" were retrofit into 2,989 homes, nearly meeting the project's goal to weatherize every electrically heated home in the county (Schoch 1987).

The pressure on Bonneville to "do something" about including manufactured homes in weatherization efforts was not internal nor did it come from the Council. These moves were afoot long before the Council's first regional plan was completed. They came from some of Bonneville's utility customers who were beleaguered by peak loads and accelerated growth in residential demand. The pressure from these customers to include manufactured homes in existing programs led Bonneville's Technical Support Branch to take the auspicious step of initiating its own comprehensive assessment of manufactured housing weatherization issues in June 1983.

\section{Retrofit Takes a Back Seat}

In June, the branch went ahead with its proposed study even though the Council's 1983 plan, released just five weeks earlier, minimized retrofit programs and emphasized new residential construction. The plan stated "new buildings present one of the most significant opportunities for achieving cost-effective conservation .... it is vital to ensure that any building using electric space heat is built to efficient standards -- even during periods of surplus" (NWPPC 1983). The MCS, which were first published in the 1983 plan, specified only the maximum electric energy use permitted for space heating in a new building. For single-family and multi-family dwellings, the performance standards established in 1983 are shown in Table 3.1 (NWPPC 1983).

The MCS for the region's residential sector were to be the basic standards against which all future conservation efforts would be judged. But if the new "rules" were difficult for Bonneville to comprehend and execute, everyone involved knew they would be nigh impossible for the residential building industry to understand, let alone follow. Accordingly, one of the first priorities established was demonstration of the standards. Bonneville embarked upon an ambitious series of programs to construct new homes to the MCS.

The undertaking was monumental. The Pacific Northwest is perhaps the last, best outpost of the small builder, the stalwart craftspeople with a trusty ax, adze, and latest electronic stud-sensor. These independent craftspeople also have a not-so-trusting attitude toward regulations in general and utilities (and Bonneville) in particular. Wasn't it hardship and restriction enough to have code officials involved?

Because the independent builder was the most numerous and the site-built home the most common, all of Bonneville's initial emphasis was on site-built homes. Initially, at least, manufactured homes were not perceived either as the same kind of challenge or as a significant part of the region's housing stock. Besides, as mentioned earlier, manufactured homes were built to a preemptive federal standard. 
TABLE 3.1 - Performance Standards for Space Heating Requirements (New Home Construction)

\begin{tabular}{|c|c|c|c|}
\hline \multirow[b]{2}{*}{ Building Type } & \multicolumn{3}{|c|}{ Climate Zone ${ }^{(0)}$} \\
\hline & $\begin{array}{c}1 \\
(k W h / s q . f t . / y r)\end{array}$ & $\frac{2}{(k W h / s q . f t . / y r)}$ & $\begin{array}{c}3 \\
(\mathrm{kWh} / \mathrm{sq} . \mathrm{ft} . / \mathrm{yr})\end{array}$ \\
\hline Single-Family & 2.0 & 2.6 & 3.1 \\
\hline Multi-Family & 1.2 & 2.3 & 2.8 \\
\hline \multicolumn{4}{|c|}{$\begin{array}{l}\text { (a) Climate zones are based on the number of heating degree days experienced in a particular } \\
\text { location (Zone 1: less than } 6,000 \text {; Zone 2: } 6,000 \text { to } 8,000 \text {; Zone 3: more than } 8,000 \text {. } \\
\text { Source: } 1983 \text { NWPPC }\end{array}$} \\
\hline
\end{tabular}

\section{Beginning a Technical Task}

Bonneville's Technical Support Branch had a tradition of independence and was unique in several respects (see Box, Technical Support Branch: an Overview). The branch was, for example, made up largely of engineers. Although engineering skills would not have been unusual for a typical Bonneville operating unit in earlier times, in 1983 it had begun to be uncommon in Bonneville's rapidly expanding Office of Conservation. Besides its technical bent, the branch was also unusual because it included more career Bonneville employees than most other branches in the Office of Conservation.

It is likely that because of its Bonneville experience and technical orientation, the technical staff members instinctively mandated an approach and standards for the manufactured housing study that were perhaps more rigorous and rigid than those of many other programs under consideration or review by program managers at the time. In hindsight, the manufactured housing project may have succeeded in great measure because of its technical authorship.

On June 10, 1983, the Chief of the Technical Support Branch assigned the task of developing a "paper on retrofit weatherization issues relating to mobile homes." I It was suggested that the project begin by interviews with Bonneville program and technical managers as well as conservation managers of utilities with a great deal of interest in manufactured housing. It was stressed that this first stage of the study was not to provide answers but simply to

- identify all of the pertinent issues; and

- discuss these issues in clear, concise language.

As indicated, the omission of manufactured housing from program development (either new construction or retrofit) was not an oversight. These homes presented real problems. One major concern focused on the jurisdiction issue but another problem was the common perception that the variation in the design, construction, and quality of existing homes -particularly those built before 1976 - - was virtually unlimited. After 1976, manufactured homes were built to the minimal energy standard included in the Federal Manufactured Housing Construction and Safety Standard.

\section{The First Issue Paper}

The issues of the preemptive HUD code and variation in design were broadly known and always in the background of any discussion of manufactured homes. In July 1983, a month after the initial request, Bonneville staff had delineated a far more extensive and well- 


\section{TECHNICAL SUPPORT BRANCH An Overview}

When instituted in 1972, Bonneville's fledgling Office of Conservation consisted of only two staff members - both engineers. As the office evolved, its key staff members conducted pionecring conservation efforts long before the passage of the Pacific Northwest Electric Power Planning and Conservation Act. After the Act became law, this initial staff became the nucleus of the Technical Support Branch with, not surprisingly, a tradition of independence and a technical orientation.

Following formation of the Council and the initiation of Bonneville's first conservation programs, these technical resources and the experience already available at Bonneville would shift their focus to the needs of program managers. Even so, there were still unassigned opportunities to explore and Bonneville often needed to respond to the ideas and concerns of its customer utilities. In the early 1980 s and in the transition to carrying out the Council's Action Plan, it was not unusual for the branch to "pick up the slack."

The branch developed a reputation for being overly technical at times. Its technical orientation, the agency experience of its staff, and the relatively long history of the branch did combine to create a unique and generally cautious approach and outlook. Far from being overtechnical, however, the branch saw itself as providing continuity and a sound scientific basis for the many new conservation programs that Bonneville was developing -a continuity of conscience to help guide planners through the fervor of the times.

articulated set of issues than had ever been developed in the past. Manufactured homes are described throughout the issue paper (and in most correspondence from the period) as "mobile homes." Highlights from this issue paper are included below: ${ }^{2}$

\section{Heat Loss Methodology}

There is no developed method to accurately predict the annual heat loss of a mobile home. While methods have been adapted from techniques used for site-built homes, there are problems associated with these adapted methods: a. U-values may differ from site-built homes due to design, construction codes and standards, materials, and earth-tobuilding interface.

b. Infiltration rates are probably less for typical mobile homes, but no data are available.

c. More experience and analysis has been gained from site-built homes. Mobile homes are relatively new in the residential marketplace, and standards and practices used throughout the industry have varied over time. Also, very little testing has been done, especially with regard to retrofit insulation.

\section{Life Expectancy}

Most mobile home stock appears to be relatively new suggesting either that mobile homes have a short life expectancy, or that economic conditions have created a recent demand for new units. Recently, for example, 30-year mortgage money has been made available for the first time. This issue should be researched, reported, and reviewed. If the life expectancy of a mobile home is shorter than some or all of the applied weatherization measures, this would greatly influence the pay-back period and the allowable limits of program funding.

All or part of any weatherization benefits could be lost should the mobile home be moved. Some units could be moved out of the Pacific Northwest region and all investment would be lost and in other cases any movement may destroy the integrity of the applied weatherization measures. Although these scenarios appear to have low probability, they should be investigated.

\section{Specifications}

Some work to develop specifications for the retrofit weatherization of mobile homes is 
already proceeding at BPA. This work is based on roof capping, underfloor insulation, duct wrapping, and wall insulation. Some of these [measures] have evidence to support their energy savings and cost-effectiveness, others do not; they should be investigated.

The Department of Housing and Urban Development (HUD) has promulgated specifications for mobile home construction since 1976 but there are no standards for the retrofit of mobile homes. However, there is an indication that some retrofit measures could violate structural or manufacturing codes.

The manufacturer of mobile homes survives in a very competitive and costconscious atmosphere. Some procedures reduce the effectiveness of the applied measures. For example, the packing or crushing of insulation materials during manufacturing can seriously affect the thermal performance of the walls, ceiling, or floor. Current construction practices may decrease overall insulation effectiveness when floor joists are placed over a continuous mat of floor insulation.

\section{Indoor Air Quality}

The use of non-structural perimeter barriers (skirts or retaining walls) can reduce air flow beneath the mobile home. Such air flow reductions may create air pollution problems inside the residence. Our present policy is to avoid the application of infiltration reduction techniques. This policy should be reviewed and recommendations for approved perimeter barriers and wood stoves should also be investigated.

\section{Designs. Codes. Certification, and Alterations}

Most present mobile homes are designed to hinder easy or inexpensive retrofit measures. For example, flat or low-sloping roofs virtually have no room for additional insulation materials. The use of glued and stapled components with continuous material sheets creates membrane barriers, making access and closure difficult.

Some state certification may be required before changes are made in the thermal or construction integrity of mobile homes. This should be documented for each state in the $B P A$ service area. Some alterations may not be allowed.

Fire, safety, and construction codes can be easily violated for roofs, vents, and chimneys. These should be investigated and reported. In general, the [Federal] Construction and Safety Standards, National Fire Protection Association, and the American National Standards Institute (ANSI) standards should be reviewed.

\section{Existing Practices}

Various individuals and utilities have applied a variety of retrofit measures in the. past. Some have been successful, some have not. These practices should be surveyed and reported.

Sometimes retrofit measures are not properly installed. For example, necessary vents may be plugged when insulation material is installed or gaps may be left in the insulation cover. Retrofit measures using batt insulation are usually cut for stick-built homes with widths between studs that are different than those in mobile homes. Although special widths are available, this is not widely known or used.

\section{Reporting}

Present record keeping and reporting techniques for the BPA weatherization program are inadequate for mobile homes. Information on mobile homes is not separated out in BPA's Central or Field offices. Utility customers could break-out 
this information, but this is not done normally or adequately. A better reporting system is needed.

\section{Verification}

The proper installation of weatherization measures would be difficult to verify except in cases where the installation is observed directly. A special verification system would be needed to implement any mobile home program.

\section{Interested Parties}

A variety of federal, state, and local agencies and both public and private parties have an interest in the development, sale, and installation of retrofit measures. $A$ complete list should be compiled.

\section{Statistics and Facts}

Many statistics and facts should be collected on mobile homes to ascertain: average age, year of construction, location, source of space heat, ar.rual consumption rates, etc.

\section{Tackling the Issues}

The issue paper had set Bonneville's number crunchers and fact grinders turning - albeit grinding "exceedingly fine." How apt and timely the new manufactured housing project! Just 4 days after the initial memo, the June 14, 1983, Journal of Commerce reported that manufactured home sales had jumped to their highest level in several years. The Journal reported that first-quarter, 1983 sales figures were $19 \%$ ahead of the previous year's levels.

This confirmed what some utilities had been telling Bonneville; but the article could have only intensified the frustration of those studying the issues at the time. One of the key issues emerging was that manufactured home penetration varied widely and national figures could not simply be extrapolated into the region or a local area. This was why some utilities were vitally interested and others couldn't see what all the fuss was about. And -- at least for the moment - determining how and where to obtain reliable local statistics was a key issue. Even very early on, however, some confirmation that manufactured housing represented a substantial number of the homes in the region was obtained from the U.S. Census (see Table 3.2).

\section{Questions, Questions}

Throughout the summer of 1983 , several members of the Technical Support Branch held regular meetings to share information that had been developed. At this time, the Conservation Engineering Branch, part of Bonneville's Office of Engineering, provided research, development, and engineering technical support for Bonneville's conservation efforts. In this case, the engineering group would help evaluate conservation measures. After the initial issue paper had been circulated, it was agreed that more study was required. The key areas of investigation were identified and individually assigned to Bonneville staff members. ${ }^{3}$ (See Box - Topics for Inquiry.)

TABLE 3.2 - Manufactured Homes In BPA Service Area (1980)

\begin{tabular}{||l|c|}
\hline Washington & 102,743 \\
\hline Oregon & 86,477 \\
\hline Idaho & 40,788 \\
\hline Western Montana & 15,759 \\
\hline TOTAL & 245,767 \\
\hline
\end{tabular}

Along with these specific topics for investigation, any additional information that was likely to prove useful was garnered. By the end of the summer, Bonneville had contacted the U.S. Census Bureau, state agencies maintaining records of manufactured homes, appraisers, and private industry. As the data on existing manufactured homes was being 
developed during the summer of 1983 , the Bonneville technical team established some general background information that would provide a much more thorough understanding of the housing category:

- The average life expectancy of sited manufactured homes for estimating purposes would be about 21 years. This estimate was based on the 1983 edition of the "National Mobile Home Manufactured Housing Appraisal System (NMHMHAS) which reflected average extreme values from 11 to 31 years.

- Preliminary infiltration data obtained from HUD indicated that manufactured homes were considerably tighter than site-built homes (a finding that extensive testing would later prove to be accurate).

The manufactured housing project was hardly launched before it emerged as one of the most ambitious, complex projects that the Technical Support Branch had ever undertaken. Fortuitously, the project began in an

at a time when relationships and procedures had not yet crystallized and projects were begun on sheer initiative and curiosity. The seekers after truth had their work cut out for them.

\section{Find Notes}

1 Internal memorandum from the Chief of the Technical Support Branch to the General Engineer of the Technical Support Branch, June 10, 1983. Bonneville Power Administration, Portland, Oregon.

2 Issue paper on mobile home retrofit insulation circulated via interoffice message, July 13, 1983. Bonneville Power Administration, Portland, Oregon.
MANUFACTURED HOME, PROJEC'T TOPICS FOR INQUIRY

\section{Stativatice}

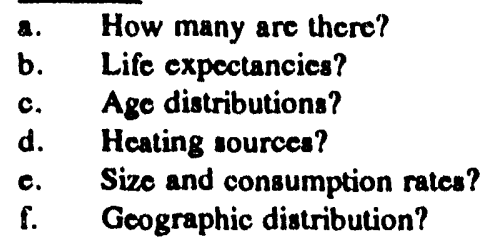

a. How many are there?

b. Life expectancies?

c. Age distributions?

d. Heating sources?

c. Size and consumption rates?

f. Geographic distribution?

\section{Heat Loss}

a. Existing U-values?

b. How to identify U-values during the analysis?

\section{Mensure:}

a. Types installed in this region and in others?

b. Quantities installed?

c. Quality of installations?

d. Installation procedures?

c. Inspection verification:

Can it be done?

If so, how?

Do you have to see it?

f. Costs and life expectancics?

Eedernl and State Requlations

a. What are they?

b. How do they affect retrofit measures?

Indoor Air Quality

a. Any specifics?
3 Internal memorandum from the Public Utilities Specialist to Task Group Addressees, August 2, 1983. Borneville Power Administration, Portland, Oregon. 


\section{CHAPTER 4: LEARNING THE ROPES -- A Name, a Database, a Vision}

Between the initiation of the manufactured housing retrofit study project and its final evolution into a new homes program, a conversion of sorts took place. What began as a fact-gathering project, a simple analysis of the retrofit potential of manufactured housing, would become, after a year of intensive and farranging investigation, a long-term vision of a "total" program to integrate manufactured housing into Bonneville's mainstream efforts to achieve conservation in new residential construction. While casual hindsight may suggest the effort evolved smoothly, the work at the time was difficult -- frustrating, sometimes downright discouraging, fraught with detail and occasional blind alleys.

Somewhat open-ended studies such as these embrace several alternate courses of study and analysis. Opting for any one of them can alter the course of the study, the work, and the outcome. In this case, there were other factors affecting the direction of the study that complicated the situation even more. There were, for example, basic changes in the methods that Bonneville used to forecast future resource needs, the way the Agency worked with the region's power planners (notably the Council), and the role Bonneville would begin to play in altering the region's building codes and construction practices. While none of these bore directly on this first manufactured housing study, the environment was certainly in a state of flux. This meant that unrelated but important events sometimes altered the way in which the project was viewed and the direction it would take.

For the time being, in late 1983 and early 1984, the chalienge was to hegin to answer as many basic questions about manufactured homes as possible. These had been focused at the outset in five areas: statistics, heat loss estimates, rieasures, regulations, and indoor air quality. Somewhire along the way, the homes

\section{THE ISSUE OF LIFE EXPECTANCY A Key Factor in Assessing Retrofit Potential}

The life expectancy of a home determines the useful life of any retrofit measures installed. Manufactured homes present special problems - life expectancy cannot be simply computed from registration data. For example:

- Physical condition, maintenance, and location are critical; an older home could outlast a new one based on these factors.

- Construction quality is determined at the factory; most manufacturers sell a range of models ranging in quality.

- Life expectancy can be affected by a change in the original design/structure.

The initial methodology used to calculate the estimated remaining year life expectancy (21 years) proved to be a reliable means to predict the economic viability of energy efficiency improvements in these homes.

had begun to be called "mobile/manufactured homes. ${ }^{\text {I }}$

\section{Tracking Down the Numbers}

While the work had been parcelled out in the five areas listed above, the two dominant issues and chief areas of investigation concerned statistics and heat loss calculations. Some very basic statistical questions had to be answered before work could sensibly proceed in the other areas -- there was no real need to determine the effectiveness of measures if the size of the market didn't justify such effort. Similarly, if the remaining life of existing manufactured homes was found to be very short, the costeffectiveness of any measure considered would be profoundly reduced. 
Accordingly, one of the lirst actions taken was to contact the Motor Vehicle Divisions of each of the four states in the region. ${ }^{2}$ These, it had been determined, were the agencies that maintained the records on "mobile" homes. But these, after all, were mobile homes. What assurance was there that these homes were located where the initial record said they were? And was location even a factor?

The researchers knew that location was a factor and played a big part in assessing a manufactured home's potential for cost-effective weatherization. ${ }^{3}$ Location determined which utility served the home owner, the climate conditions, whether retrofit contractors were available, etc. First, therefore, the relative permanence of these homes had to be assessed. Within a very short time, it was determined that, in spite of their supposed mobility, very few manufactured homes (less than $3 \%$ ) were moved after initial siting. ${ }^{4}$ One of the first findings was that "mobile" homes weren't so mobile after all.

At this point, the researchers decided that original registration data should be obtained county by county. Quite simply, there was a good enough $(97 \%)$ chance that the homes would still be there to justify the effort and expense! Generally comparable data was available from Oregon, Washington, and Montana -- Idaho, however, did not have central records. At the time the first data was received (from Oregon), the analysts commented: ${ }^{4}$

- The address will permit identification of the serving utility.

- Heat loss estimates and potential energy savings depend on the climate (annual heating degree days) at the location and the location could be determined from registration data.

- A home's make, approximate size (single-, double-, or triple-wide), and its year of manufacture can be determined from the Oregon data.

Incidentally, the Oregon Motor Vehicle Department showed a total of 120,512 mobile/ manufactured homes registered as of December 1983. This number was considerably higher than the 1980 U.S. Census figure of 86,477 homes that had been used as an initial estimate of manufactured home penetration in Oregon

\section{Heat Loss}

In regard to heat loss estimates, it was suggested that Bonneville staff contact the manufacturers in the region who "best represent a typical mobile home located in our service area." The plan was to request heat-loss coefficients for the manufacturers' various models over the past years. Armed with this data, the analysts felt they could determine potential energy savings to be achieved through weatherization measures. Foreshadowing the ultimate importance of cooperation in the project, one internal memorandum noted:4

This critical information can only be obtained with the cooperation of the manufacturer, however.

Although none of this information was presently available, the Bonneville engineers felt that manufactured homes built after 1976 would present a lesser analytical challenge. After 1976, models were measured against the energy performance standard established by the HUD code. With this standard as a benchmark, Bonneville could poll the region's manufacturers to determine the energy performance of each of their models versus the federal standard. The problem, for the moment, concerned manufactured homes built before enforcement of the federal standard in 1976. After 1976, it could be assumed that manufactured homes were all built to the federal energy standard. The manufactured homes with greatest retrofit potential were those built before 1976 . 
Inquiries had indicated that prior to 1976 the region's manufacturers had voluntarily complied with another standard -- one developed by the American National Standards Institute. First published in 1969, this standard was designated ANSI A119.1. Discussions with industry representatives indicated that this standard was generally accepted and complied with by manufacturers in Washington and Oregon even though there was no mechanism for its strict enforcement. ${ }^{s}$

The ANSI standard included a minimum requirement for heat loss in floors, ceilings, and walls, stating: ${ }^{5}$

The total calculated heat loss of the living unit at the outdoor design temperature as certified in 7.5.1 of this Part shall not exceed $40 \mathrm{Btu} / \mathrm{hr} / \mathrm{ft}^{2}$ of the total floor area or $27.5 \mathrm{Btu} / \mathrm{hr} /$ lineal foot of the space to be heated to $70^{\circ} \mathrm{F}$, whichever is greater. The minimum total resistance $(R)$, excluding framing, of the wall hess windows and doors), ceiling, and floor shall not be less than:

$\begin{array}{lr}\text { Wall } & 8.0 \\ \text { Ceiling } & 16.0 \\ \text { Floor } & 10.0\end{array}$

Indications from the Oregon data were that about $59 \%$ of the pre-HUD code homes remaining in the state were built between 1970 and 1976 and were thus constructed using these ANSI minimum standards. Some manufacturers had indicated that Oregon and Washington manufacturers were using standards similar to the ANSI standard even before 1969. If so, that would mean that even more of the existing manufactured housing stock was built to this general level of construction. ${ }^{5}$

Information on typical construction practices was needed so that an estimate of energy savings that were likely to be achieved through retrofit measures could be established. Costeffectiveness and energy savings would be

\section{BONNEVILLE'S 1984 \\ CONSERVATION PROGRAMS \\ A Sampler ( $\$$ millions)}

Residential Weatherization

S 40.22

Low-Income Weatherization

$\$ 3.02$

Street and Area Lighting

$\$ 2.38$

Institutional Buildings

$\$ 7.55$

Hood River Conservation Project S 2.00

Super Good Cents Promotion $\$$ S .61

calculated by comparing the energy performance achieved with retrofit measures to the estimated performance, based on heat loss characteristics, of the region's pre-1976 manufactured housing stock.

\section{Measures}

Bonneville had fostered a good forum to explore and discuss weatherization measures, one that could be constructively applied to manufactured homes. The Res-Wes program was conducted at such high levels of activity that it had become broadly known among the regional contractors. The agency had discovered that feedback from these contractors was often useful and that establishing forums for the interchange of experience and ideas paid off in terms of developing new measures and/or application techniques.

One such series of meetings was scheduled in January of 1984, in Portland and in Spokane. ${ }^{6}$ Called the Residential Weatherization Contractor Participation Meetings, these events seemed to provide an excellent opportunity to present some of Bonneville's initial ideas concerning appropriate -- or inappropriate -- measures that might be applied to manufactured homes in the region.

Using the site-built contract specifications as a guide, the researchers had studied ways in which manufactured homes could be retrofit. This research also highlighted several issues that would affect retrofitting of manufactured homes: ${ }^{7}$ 
- Wall insulation may not be cost-effective for many manufactured homes because the stud dimensions limited the cavity size and because opening the walls appeared to be difficult and expensive.

- Rigid roof insulation could be readily applicable to these homes provided that no) attic access was required and/or ceiling loads were not exceeded. (The attic space in manufactured homes was severely restricted and the relatively low roof angles made ceiling loads a critical factor.)

- Manufactured home floor construction may present problems because of barriers and construction details. (The homes required special undercarriages to transport them from the factory to the site. While this carriage was, after all, what made the home "mobile," it could also make the floors of these homes difficult to retrofit with extra insulation.)

- If skirting were used to reduce under-floor infiltration, Bonneville felt that mesh venting would be required to maintain air circulation and prevent the build-up of air pollutants, e.g., radon, carbon monoxide, etc.

- HUD had recently proposed that a standard be established to restrict formaldehyde levels and any retrofit measures should take these into account in the event HUD promulgated such a standard.

- While Universal Building Code (UBC) compliance is not required of HUD code homes, they must comply with federal standards and these should be used by contractors in place of the codes that were used as guidelines in site-built retrofits.

\section{Regulatory Issues}

Within a very short time, even before the summer of 1983 was over, it had hecome clear that Bonneville had incurred a new role. As a consequence of its increasing involvement and interest in the manufactured housing category and the Council's 1983 Plan, Bonneville had become, willingly or not, an "interested party" in the regulatory issues that were nearly always brewing back at HUD. Bonneville was asked to comment on a pending project to set up an advisory panel on development of a new HUD code. In a memorandum dealing with this project, Bonneville staff members working on the manufactured housing project envisioned an appealing research scenario in which they hoped HUD would take an active part. The region would discover that HUD would be limited in its ability to conduct such investigations. The Pacific Northwest would have to proceed largely on its own in its quest for manufactured housing energy savings.

The project included several tasks: ${ }^{8}$

- verifiying different heat loss methodologies as applied to new or retrofit manufactured housing

- determining the actual energy savings of manufactured homes built under the 1976 HUD code standard and any proposed new standard

- establishing the number, age, size, and location of mobile/manufactured homes in the Northwest

- calculating the improved energy efficiency and cost-effectiveness achieved by the use of heat-pump space heating

- evaluating the effect of different mitigating devices and methods used to reduce formaldehyde concentrations levels and indoor air quality problems.

At the time the Council published its first power plan for the region, the manufactured housing project had not yet been launched; nevertheless, the Council was interested in the energy-saving potential of these homes. The Council's action plan (Action Item 2.6) required Bonneville to "assist the ... U.S. Department of 


\section{TAKING THE REgULATORY PATH Mandating Energy Efriciency}

The regulatory approach seemed particularly appealing at this time because it matched other moves afoot in regional conservation. The Council had recently published its Model Conservation Standards for new residential construction and their impact was not yet known. While plans were still in flux, in the minds of several regional planners the long-term, least-cost path to achieving these standards was to have them enacted as building code requirements at state or (if necessary) local levels.

It was simply a logical extension of this approach to place similar emphasis on regulatory tools for new manufactured housing as well. The proposed review of the HUD energy standard seemed like a golden opportunity to achieve energy efficiency through code enforcement - by mandate.

As time went on, it would become clear that this approach would not work quite so smoothly in either site-built or manufactured housing - but these efforts held center stage for much of the second half of 1983 and all of 1984 .

Housing and Urban Development to develop and adapt electric energy-efficiency standards for manufactured housing in the Pacific Northwest" (NWPPC 1983).

In April 1984, commenting on a proposed HUD cost impact analysis, Bonneville urged HUD to include a cost analysis of available thermal options, noting that subsection 3280.51 of the basic authorizing legislation required manufacturers to offer customers at least one energy-efficient design option. In its official comment, Bonneville stated (BPA 1984e):

A cost analysis of this option could be a major influence in the customer's decision. Long-term energy savings could far outweigh the initial costs. Without this analysis, the customer cannot make an informed decision.

\section{A Shift in Focus}

As the retrofit study was progressing, the same people working on developing data for the study were providing input into Bonneville's initial responses to the regulatory issues that had arisen. Of course, these issues involved new construction and not retrofit. In an ideal world, these investigations would have taken place sequentially or been separated, but because the timing for the region's response on regulatory issues was dictated by HUD, the need to respond to regulatory issues had the effect of shifting some of the emphasis of the analysis from retrofit to new construction.

Other events also contributed to a shift in focus. The Council had recently completed the monumental task of developing MCS for residential construction in the region. These were clearly the way of the future and, equally clearly, there was a great deal to be done to bring the MCS from misty theory into solid practice. There was a shift in regional priorities, and a shift, therefore, in Bonneville's priorities. By mid-1984, the retrofit study had spawned what was really a corollary project concerned with new homes -- one that was ultimately to eclipse the original effort.

As indicated, the Council's Action Plan called for Bonneville to assist HUD in the development and adoption of electric energyefficiency standards for new manufactured housing in the Pacific Northwest (NWPPC 1983). HUD had asked for public comment on a proposed revision to the original 1976 standard and the Council had requested that Bonneville respond. While the timing of this revision was not specified, most participants -the Council, the Office of Conservation at Bonneville, other regional planners, and researchers -- undoubtedly thought of this as a somewhat near-term project. Ultimately, it would take HUD far longer to act on revising the standard than anyone imagined in 1984. 


\section{The Retrofit Study}

Meanwhile, what of the initial project? On May 30, 1984, the Mobile/Manufactured Home Retrofit Study was circulated throughout the Office of Conservation at Bonneville (Onisko and Van Orden 1984). The study focused on the application of retrofit measures to manufactured homes built before the HUD code standard was established in 1976. Pre-1976 homes were evidently singled out because of their greater upgrade potential. The study noted that nearly all Bonneville experience with retrofit weatherization measures was with sitebuilt homes.

Highlights of the report (Onisko and Van Orden 1984) are presented below:

\section{Recommendation}

The initial study recommended that Bonneville not include mobile/manufactured homes as eligible residences in the weatherization program and outlined some of the most vexing problems likely to be encountered, including (a) difficulty in applying measures, (b) higher installation costs, (c) the variety of mobile home stock, (d) the short estimated remaining life of the "typical" mobile homes, and (e) the questionable costeffectiveness of the energy savings acquired. On the other hand, the study recommended that Bonneville promote building standards for new mobile homes because they account for $40 \%$ of sales of all new electrically heated homes in the region. This latter course represented the greatest potential for savings, according to the report.

\section{Construction}

Although construction techniques are similar from plant to plant, manufactured homes are extremely diverse, a factor which makes installation of conservation measures more difficult. It was assumed that most pre-1976 homes in Washington and Oregon were huilt to ANSI 119.1 Standard for Mobile Homes with minimums of R-8 insulation in walls, R-16 in cuilings, and $R-10$ in floors.

- Built as an integrated structure to withstand transport conditions, the mobile home features a small roof cavity to reduce overall height and permit travel on roads with low bridges and overpasses.

- The walls are glued and stapled to vertical studs, designed to help withstand shear stresses during transport and transmit the roof load to the floor. Prior to 1976, most walls were built using either $2 \times 2$ - or $2 \times 3$ inch studs leaving a shallow cavity with little room for insulation material. If built to the ANSI specification, up to $2 \%$ inches of batt insulation may have been installed in the cavity at the factory. Air infiltration barriers were not always used in wall construction -- moisture was usually vented; sealing against moisture was rare.

- In addition to the bottom board, ranging from a $\%_{6}$-inch asphalt-impregnated insulation board to a tear-proof impregnated fabric, floor insulation systems use $1 \frac{1}{2}$-inch-thick blanket insulation across the length and width of the floor (the "belly blanket") fitting between the joist and the steel carriage frame.

\section{Typical Mobile/Manufactured Homes}

In Oregon registrations prior to 1976 , singlewide homes outnumbered double- and triplewides by a ratio of five to one. At the time it was believed that the single-wide home best represented the region's stock of existing homes and therefore it was used as the basis of the retrofit study report. Characteristics to describe this home are outlined in Table 4.1.

The width estimate was based on the fact that, prior to 1956, all manufactured homes were 8 feet or under in width. In 1956, the 10foot width was introduced, and soon dominated the market. Later, in 1962, the 12-foot width was introduced and in 1969 the 14-foot width 
TABLE 4.1 - Typical Mobile/Manufactured Home

\begin{tabular}{||l|c|c|}
\hline \multicolumn{2}{|c|}{ Single-Wide $(11 \mathrm{ft} . \times 7 \% \mathrm{ft} . \times 66 \mathrm{ft})^{(0)}$} \\
\hline \multicolumn{1}{|c|}{ Component } & Area (sq.ft.) & R-Value (Total) \\
\hline Ceiling & 660 & 16 \\
\hline Floor & 660 & 10 \\
\hline Walls & 1,020 & 8 \\
\hline Glazing (Single) & 90 & 1 \\
\hline Door & 40 & 2 \\
\hline $\begin{array}{l}\text { (a) The 11-foot-wide typical home used in this analysis does not exist, but on average it best } \\
\text { represents the pre-HUD standard homes in the region. }\end{array}$ \\
Source: Onisko and Van Orden 1984
\end{tabular}

was introduced with similar results. The average mix of these widths suggests that manufactured homes ranged between 10 and 12 feet in width.

The estimated annual electricity use of these homes was between 9,000 and 13,000 kWh per year. The typical manufactured home was estimated to be about 14.5 years old, registered in 1968, with a nominal remaining life expectancy of about 15 years.

\section{Retrofit Measures}

Heat loss reduction through walls, ceiling, and floors is the first major consideration. Either batt or loose-fill insulation is an accepted practice for conventional homes but manufactured homes present several problems.

- Walls - Restoring external finishes and water leaks are potential problems. Because of the small cavity, it is doubtful that more than R11 thermal resistance can be added, making the value of the effort versus its cost (estimated at $\$ 1.00 /$ sq.ft. of siding) questionable.
- Ceilings - Compared to site-built homes, attic space is virtually inaccessible and limited space may cause uneven distribution of insulating material. Various means of increasing insulation were discussed, including capping vented roofs (a new roof system built over the existing roof) or constructing a ramada (a roof system not attached to the home in any way) at costs estimated between $\$ 4$ and $\$ 6$ per sq. $\mathrm{ft}$.; capping unvented roofs using a roll-on insulated blanket ( $\$ 3.75$ to $\$ 5$ per sq.ft.); spraying polyurethane foam over the surface; and laying and covering sheets of polyisocyanurate with sheet metal, etc.

- Floors - Space is restricted and manufacturers have developed unique undercarriage and floor joist systems, making standardization difficult and floor upgrades likely to be labor intensive.

- Underpinning - Skirting can be an important measure, reducing heat losses by decreasing air flow. Alternative materials are aluminum, plastic, styrofoam, and plywood (not recommended). The chief disadvantages are short life expectancy and moisture problems. Solid, firm foundations, e.g., 
concrete pads, can provide a firm base, prevent settling, reduce cracks and leaks, and maintain the integrity of caulks and seals.

- Glazing - Single glazing is predominant. Older homes feature awning type windows; slider type windows became widely accepted with later homes. Providing emergency exits and egress through windows is a major design concern with manufactured homes. Inside storm windows may be the only reasonable choice in many cases. Nearly all of these would have to be custom-made at an installed cost of approximately $\$ 7.50$ per sq.ft.

\section{Location}

Location and set-:p play an important role in the energy usage of a manufactured home.

\section{Building Codes}

Building code officials in Oregon and Washington have expressed concerns about the application of weatherization measures that could affect the structural integrity of mobile/ manufactured homes. Measures requiring a permit, and therefore an inspection, create additional administrative costs for contractors. These states have indicated they are most concerned with measures affecting roofs and ceilings.

\section{Energy Savings and Costs}

Three major factors determine the value of any weatherization measure:

- the annual energy saved which is attributed to the applied measure

- the installed costs, including materials and labor

- the life expectancy of the measure without major degradation in its performance (this is limited by the remaining life of the home).
Tables for adjusting costs to account for financing, discount rate, and cost levelizing factors were included in the retrofit study report for use in determining the levelized cost/ $\mathrm{kWh}$ of retrofit measures to the region.

\section{Specifications}

Specifications were designed to give the potential installers flexibility while remaining within state, local, and federal requirements. The specifications also stated that the contractor would be liable for damage resulting from the measure or its installation and would be responsible for restoring material to its original condition. The following specifications were outlined in the report, evidently in spite of the recommendation that mobile/manufactured homes not be considered eligible for retrofit programs/measures:

- Walls - Walls shall be insulated to a minimum R-19 or the highest practical Rvalue by cutting holes in the sheathing or peeling back all or part of the exterior siding and adding insulation.

- Roofs/Ceilings - Ceiling cavities shall be insulated to a minimum R-38 or the highest practical $R$-value by building a roof system over the existing roof, removing a portion of the existing roof, cutting a hole or other means of penetration to gain access to the cavity, or cutting a hole in the eaves and then insulating ceiling cavities.

- Floors - Floors shall be insulated to a minimum R-19 or the highest practical $R$-value without penetrating the rodent barrier, subfloor, and/or bottom board. Full skirting is required prior to applying any insulation; no insulation shall be applied in the presence of significant moisture damage. All installations shall require that a ground vapor barrier be installed. 


\section{New Players, New Plans}

By the time the retrofit study was complete, the mandate to deal with regulatory issues, the region's preoccupation with the MCS, and the difficulties inherent in the retrofit approach had convinced the project's managers that the real opportunity in manufactured housing was in new construction. This brought new people into the picture. New construction and the achievement of MCS involved other Divisions in Bonneville's Office of Conservation; both the Division of Planning and Evaluation and the Division of Residential Programs now became involved.

Even before the final retrofit report, a top priority project had been instituted to provide technical support for manufactured homes. A complete action plan was drawn up in mid-1984 that would become the agenda, the action plan, the vision for the future. 9 The new assignment would require the Technical Support Branch to perform the following tasks:9

1. Survey all manufacturers and sales agents in the region to

a. determine the number, location, size, and thermal efficiency of new homes sold in the past year and available now

b. estimate the costs and savings for each energy-efficient model available to the public in the region

c. access and study all future models that will be available to the public in the next 1 to 5 years

d. collect data on regional sales through imports and exports.

2. Provide local assistance and oversight to HUD when requested, i.e., data collection, review of new plans, etc.

3. Test new homes for energy efficiency and compare the results to the costs and savings estimated for presently available energy-efficient models (item $1 \mathrm{~b}$, above).
4. Develop a heat-loss methodology unique to the climate zones of the Northwest and potentially useful at a national level.

5. Assist HUD in the development of a local market strategy directed at energyefficient homes and useful on a national level.

6. Report and recommend code changes and guidelines that result in energy-efficient construction techniques.

7. Review and comment on all information, codes, and guidelines that may affect these objectives.

8. Monitor indoor air quality changes due to higher energy-efficiency construction.

9. Review and report on all state, local, and federal legal, institutional, and market impediments to the development of energy-efficient manufactured homes.

10. Complete a market survey of public attitudes and buying habits relevant to energy-efficient manufactured homes. Include manufacturers and retail agents.

11. Assess environmental barriers caused by energy-efficient homes.

12. Collect, collate, and disseminate all policy actions involving HUD, DOE, Bonneville, and other state, federal, or local agencies.

$$
* * * * *
$$

As the manufactured housing project entered its second year, the die (all 12 detailed points of it outlined above) was cast. The course of action seemed clear, the focus of the futurc would be on new manufactured homes. Bonneville had moved from retrofit weatherization into new manufactured housing construction -- in factories, not on building sites. Another world. 


\section{End Notes}

1 Internal memorandum on the addition of mobile homes to the Residential Weatherization Program from the Public Utilities Specialist to the [Inter-Branch] Task Group. August 2, 1983. Bonneville Power Administration, Portland, Oregon.

2 Internal memorandum concerning preliminary findings on mobile home information, from the General Engineer (KTT) to the Chief, Technical Support Branch (KTT). August 4, 1983. Bonneville Power Administration, Portland, Oregon.

3 Memorandum on issues of interest and concern in manufactured homes from the General Engineer (KTT) to the Legal Research Scientist [No organization specified but assumed to be Pacific Northwest Laboratory]. Hand-dated by Chief, Technical Support Section as October 5, 1983. Bonneville Power Administration, Portland, Oregon.

4 Internal memorandum on preliminary results from Oregon Motor Vehicle Division's records on mobile homes from the General Engineer (KTT) to the Residential Programs Branch Public Utilities Specialist. January 11, 1984. Bonneville Power Administration, Portland, Oregon.

5 Internal memorandum on heat loss estimates of pre-HUD standard mobile/manufactured homes from the General Engineer (KTT) to General Engineer (KTT). January 18, 1984. Bonneville Power Administration, Portland, Oregon.

6 Memorandum from the Residential Programs Branch (KPH) to residential weatherization contractors and potential contractors. January 11, 1984. Bonneville Power Administration, Portland, Oregon.

7 Interoffice message (handwritten) from the General Engineer (KTT) to the Chief, Technical Support Branch (KTT). January 17, 1984. Bonneville Power Administration, Portland, Oregon.

8 Letter from the Chief, Technical Support Branch to the General Counsel Rules Docket Clerk (HUD), Washington, D.C. April 3, 1984. Bonneville Power Administration, Portland, Oregon.

9 Interoffice memorandum on the action plan to assist the DOE and HUD in the regional development and construction of energyefficient new manufactured housing from the General Engineer (KTT) to the Director, Division of Technical and Marketing Support (KT) via the Chief, Technical Support Branch (KTT). May 21, 1984. Bonneville Power Administration, Portland, Oregon. 


\section{CHAPTER 5: ANOTHER WORLD -- DAPLAs and IPIAs and Indians Too}

Many moves were afoot. New players were involved. Bonneville's Conservation Planning Branch was now assessing the conservation potential of manufactured homes -- studying energy conservation measure penetration and other characteristics of existing homes. The Planning Branch agreed that the present situation clearly supported the retrofit study recommendation. Nevertheless, the planners were urging, in effect, that the door be left ajar even if not completely open: ${ }^{1}$

Although the staff recommendation in the study is to not include mobile homes in the weatherization program ... useful information could be obtained from a mobile home retrofit demonstration project.

\section{IN STEP WITH THE TIMES}

As part of its focus on the long-term, BPA would launch activities to bring the MCS closer to reality. Three of these programs, discussed in detail later, would affect the future course of manufactured housing conservation efforts:

- One program, the Residential Standards Demonstration Project (RSDP) would build houses to the MCS to increase awareness and understanding of the standards by utilities, code officials, builders, and home owners. One of its key results would be to verify the cost-effectiveness of the MCS.

- A somewhat similar program, the Residential Construction Demonstration Project (RCDP) would focus more on specific energy conservation measures and builder training.

- A program to market energy efficiency to home owners, to encourage the adoption of MCS standards even before upgraded energy standards could be incorporated into local building codes, would be developed and launched. This program became well known as Super Good Cents.
Although Bonneville subsequently developed educational retrofit programs to apply to manufactured homes, the main thrust of its development efforts over the next 2 years would be directed toward impacting the design and construction of new energy-efficient manufactured homes. At this point in mid1984, when the initial Retrofit Study was completed, the Technical Support Branch had concluded that the potential cost benefits of upgraded new manufactured homes presented the greatest opportunity. "These improved homes would use one-half to two-thirds less energy than the standard models, with financial benefits to the homeowner. ${ }^{2}$

This approach was consistent with other activity conducted by the Office of Conservation. By, in effect, focusing on the future, the branch anticipated a course that would be confirmed some months later by Bonneville management. Regarding conservation as key to meeting future needs, Bonneville had made the decision to take full advantage of the regional power surplus and concentrate its conservation efforts on long-term strategies. According to the Assistant Administrator for Conservation, speaking of the long-term needs later in the year (BPA 1986):

Today's energy situation allows Bonneville the time to test and evaluate programs that will best serve these needs long after the current surpluses have vanished.

Neither the guiding statement nor the programs that would be required to support new energy-efficient manufactured homes were fully articulated when the decision to pursue new manufactured housing was made (see Box - In Step with the Times). These developments were yet to come. It was serendipity indeed that the temper of the time, the milieu in which decisions were being made, dovetailed perfectly 
with the approach recommended by the Technical Support Branch. Because it was "in step," so to speak, the manufactured housing program would find tools and resources in place by the time they were needed.

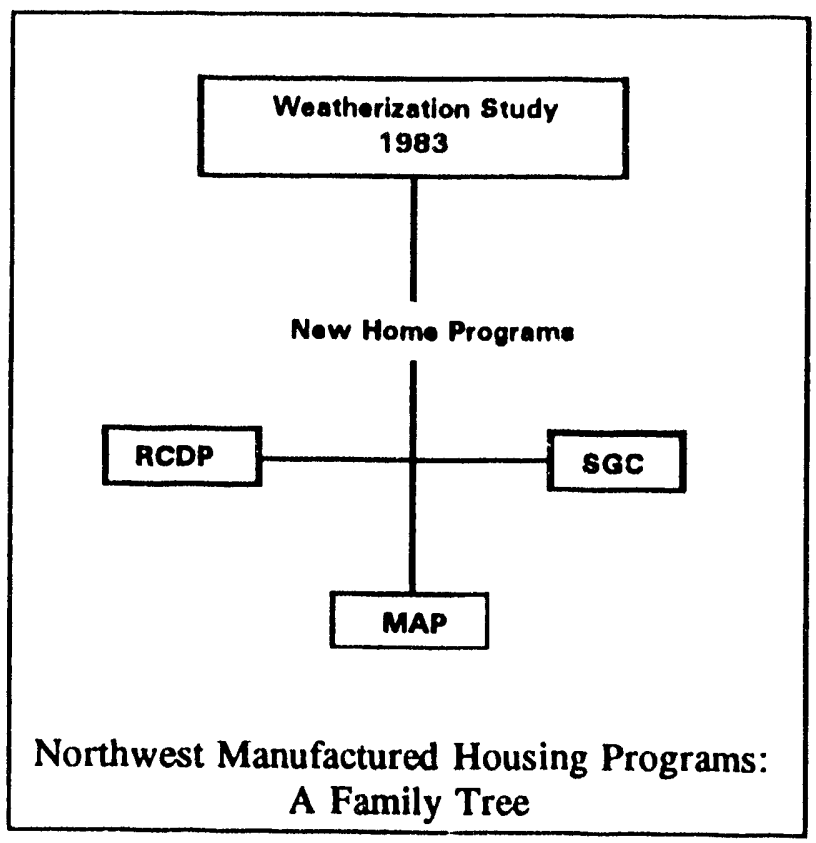

\section{Capability Building}

In the meantime, there was lots of work to do. According to the Assistant Administrator, the Council's 2-year action plan covering 1983 through 1985 revolved around the principle of "capability-building" - creating the means to acquire the conservation resource when needed (BPA 1986). And some months earlier, this was exactly the course proposed by the branch staff members although they did not use the term "capability building." In a memorandum to the Marketing Support Branch, which would become involved in any future program to support the marketing of improved manufactured homes, one of the Technical Support Branch engineers wrote: ${ }^{2}$

Further work must be done. For example, we should inventory all of the region's manufacturers and obtain more specific information. Also, we should present a program that will be attractive to the home buyer, dealer, and manufacturer.
The future looks even better. I'm told that even better-insulated $M / M$ (mobile) manufactured] homes can be built (with some structural and design modifications, however). Costs are yet to be determined.

One of the first efforts to prove the contention that significant energy savings could be achieved via totally practical and feasible upgrades to existing models was a cost benefit analysis. ${ }^{2}$ This assessment looked at three types of representative manufactured homes: $S W-$ a single-wide (12 ft. $\times 70 \mathrm{ft}$.), SDW - a small double-wide ( $24 \mathrm{ft} . \times 56 \mathrm{ft}$.), and LDW - a large double-wide (28 ft. $\times 66 \mathrm{ft}$.). These sizes corresponded to the NWPPC's MCS for sitebuilt homes (NWPPC 1983). Table 5.1 lists the specific dimensions for each home as well as the standard and extra insulation packages.

To estimate and assess the energy savings such a package would achieve, three evaluation tools were used. ${ }^{2}$

- One tool was SUNDAY, a computer modeling program that predicts annual space heating energy use based on house design and location. Northwest planners were beginning to make use of SUNDAY to estimate the performance of various design features adopted under MCS, local building codes, and other variables. The SUNDAY model takes several factors into account, including overall heat loss, internal heat gains (from people and appliances), structural heat storage capacity, internal temperature set points (thermostat), window orientation and type, and local weather.

- Another tool was a "Mobile/Manufactured Homes" energy model, also a computer. modeling program that was still in development at this time. (This program would be perfected and evaluated later -- see Chapter 6.) 
TABLE 5.1 - Prototype Dimensions and Insulation Packages ${ }^{2}$

\begin{tabular}{||l|c|c|c|c|c||}
\hline & Floor & Wall & Ceiling & Glazing & Door \\
\hline $\begin{array}{l}\text { Single-Wide } \\
\text { (sq.ft.) }\end{array}$ & 850 & 1210 & 850 & 90 & 40 \\
\hline $\begin{array}{l}\text { Small Double-Wide } \\
\text { (sq.ft.) }\end{array}$ & 1350 & 1920 & 1350 & 140 & 40 \\
\hline $\begin{array}{l}\text { Large Double-Wide } \\
\text { (sq.ft.) }\end{array}$ & 1850 & 2620 & 1850 & 190 & 40 \\
\hline Standard Insulation & $\mathrm{R}-11$ & $\mathrm{R}-7$ & $\mathrm{R}-14$ & $\begin{array}{r}2 \mathrm{G}^{(0)} \\
(1.41)\end{array}$ & $\mathrm{R}-2$ \\
\hline Extra Insulation & $\mathrm{R}-22$ & $\mathrm{R}-19$ & $\mathrm{R}-30$ & $\begin{array}{c}3 \mathrm{G}^{(0)} \\
(2.22)\end{array}$ & $\mathrm{R}-2$ \\
\hline
\end{tabular}

(a) Author's Note: "G" indicates glazing levels, i.e., $2 G$ is double-glazing, $3 G$ is tripleglazing. Figures in parentheses indicate calculated $R$ values.

- The third tool used was a HUD slide rule that could be used to determine the annual energy savings for the single-wide (12 ft $x$ $70 \mathrm{ft}$ ) case. This approach was not available for the double-wide alternatives.

Using these tools on the prototype homes shown in Table 5.1 yielded estimated average annual energy savings as shown in Table 5.2. From a utility point of view, each increment of energy saved must cost less than the cost of bringing that resource into place. Ideally, the home owner must also receive recognized cost savings to be convinced of the benefit of the energy-saving investment. Based on cost estimates of the insulation package provided by two regional manufacturers with whom Bonneville had established a working relationship, this preliminary analysis suggested strongly that both the region's utilities as well as individual home owners would benefit from the upgrade envisioned.

Based on estimated costs of $\$ 1,325$ for the single-wide package, $\$ 1,680$ for the small double-wide package, and $\$ 1,890$ for the large double-wide package, and using a 25-year measure life, these prototype manufactured homes delivered energy savings at levelized costs ranging from a low of 1.44 cents $/ \mathrm{kWh}$ (for the large double-wide) to 1.85 cents $/ \mathrm{kWh}$ for the single-wide. ${ }^{2}$

\section{Demonstrating the Savings}

By mid-summer of 1984 , there was general support for the notions about testing manufactured homes, and a proposal was forwarded from the Technical Support Branch to the Marketing Support Branch for evaluation. $^{3}$ At other points in time, developments would be smoother, more technically based, more strategically driven. But in mid-1984, there was no paucity of energy-saving ideas in the Pacific Northwest and no shortage of potential demonstration programs for Bonneville to assess. In fact, programs and projects had to compete for attention and funding in a kind of energy-saving glamour contest. In hindsight, Bonneville did well to operate as smoothly, as technically based, and as strategically driven as it did. 
TABLE 5.2 - Estimated Annual Energy Use and Savings Using SUNDAY, M/M Model, and HUD Slide Rule ${ }^{2}$

\begin{tabular}{|c|c|c|c|c|c|}
\hline $\begin{array}{l}\text { Type Of } \\
\text { Home }\end{array}$ & Case & $\begin{array}{c}\text { (SUNDAY) } \\
\text { kWh }\end{array}$ & $\begin{array}{c}\text { (M/M Home) } \\
k W^{(0)}\end{array}$ & $\begin{array}{l}\text { HUD Slide } \\
\text { Rule }\end{array}$ & $\begin{array}{c}\text { Avg. kWh } \\
\text { Savings }\end{array}$ \\
\hline \multirow{3}{*}{$\begin{array}{l}\text { Single- } \\
\text { wide } \\
(12 \mathrm{ft} . \times 70 \mathrm{ft} .)\end{array}$} & Base & 6,565 & 12,444 & \multirow[b]{3}{*}{5,600} & \multirow[b]{3}{*}{4,800} \\
\hline & Extra Insulation & 2,526 & 7,507 & & \\
\hline & Savings & 4,039 & 4,937 & & \\
\hline \multirow{3}{*}{$\begin{array}{c}\text { Double- } \\
\text { wide } \\
(24 \mathrm{ft} . \times 56 \mathrm{ft} .)\end{array}$} & Base & 10,554 & 17.637 & & \multirow[b]{3}{*}{6.800} \\
\hline & Extra Insulation & 4,383 & 10,381 & & \\
\hline & Savings & 6,171 & 7,256 & & \\
\hline \multirow{3}{*}{$\begin{array}{l}\text { Double- } \\
\text { wide } \\
(28 \mathrm{ft} . \times 66 \mathrm{ft} .)\end{array}$} & Base & 12,273 & 23,032 & & \multirow[b]{3}{*}{8,700} \\
\hline & Extra Insulation & 4,443 & 13,372 & & \\
\hline & Savings & 7,830 & 9,660 & & \\
\hline \multicolumn{6}{|c|}{$\begin{array}{l}\text { Author's Note: These estimates were based on the mobile/manufactured home model } \\
\text { being developed by Bonneville at the time. While the consumption estimates varied } \\
\text { significantly from those obtained using SUNDAY, the BPA author pointed out that the } \\
\text { savings estimates were roughly comparable. }\end{array}$} \\
\hline
\end{tabular}

Program proposals, ideas good and bad, had to compete and had to make their case clearly, convincingly, dramatically -- and succinctly. It was, therefore, no small challenge and accomplishment to advance the case for verifying the energy performance of manufactured housing, particularly in view of the fact that the Council had not embraced the housing category in the new buildings included in the residential sector in its action plan. The proposal -- which varied in detail, but not in substance over the next few months -- was simply: ${ }^{3}$

Twelve newly constructed single- and double-wide manufactured homes will be tested to determine the effects of improved energy efficiency requirements on the indoor air quality and energy savings of those homes. In addition, regional manufacturers will be surveyed to determine if any indoor air samples have been routinely collected and recorded.

So far, so good. There was general acceptance of the idea of a test and by the end of the summer the scheme had been fleshed out, expanded to a concept of a total program called the Energy-Efficient Manufactured Housing Test and Marketing Program. ${ }^{4}$ But specific details were harder to agree upon and progress slowed when questions of the number of homes to test and how to monitor them proved difficult to resolve and agree upon quickly.

The number of homes had shrunk -- to nine at this time." Because an energy-monitoring program (known as ELCAP) was already in place, it was suggested that the homes be monitored for at least a year under occupied 


\section{MONITORING: A RANGE OF OPTIONS}

Since 1979, Bonneville's Division of Planning and Evaluation in the Office of Conservation had collected energy use data from a regionwide sample of residential and commercial users. Called the End-Use Load and Conserva ion Assessment Program, ELCAP for shor, the program was designed to provide sound, comparable data about energy consumption characteristics in the region, across a range of locations, customer types, and conditions.

With an extensive database and established protocol, the ELCAP program relied on a network of monitors and data loggers that were installed in occupied buildings to collect raw consumption data which was then "filtered" to cetect and screen out errors and fill in missing data. While far from perfect, it was state of the art in 1984. There was sentiment in 1984 ior extending ELCAP and using it to measure all tests and demonstrations.

conditions as part of the ELCAP program (see Box - Monitoring). The advantage of this approach would be that resuits would be romparable to other data and the data would permit development of projections of the energy performance and savings potential of the test homes.

This suggestion was duly explored and investigated. The problem, however, was that the number of homes was too small to provide a statistically valid sample upon which to base major program decisions. In the view of the Planning Branch (w!;ich was becoming involved along with the Marketing Support Branch), a minimum of 25 homes would be required, perhaps even more $d$ spending on the information being sought and the purpose for which it was to be used. ${ }^{4}$

Momentum was slowed as the thorny questions of monitoring approach, sample size, and assessment costs were weighed and discussed. These issues affected the contract package being prepared to purchase the test homes, changing the nature of the project and the Request for Proposals (RFP) specifications. Never an easy, rapid procedure, the purchasing process slowed even further under the impact of uncertainty. It would be another 6 months before the RFP was ready to mail to prospective suppliers.

\section{Reaching Out}

In the meantime, more and more contacts were being made with the industry, with others in the region with interest and/or capabilities to offer, and with the federal agencies, HUD and DOE. Contacts had been made with regional manufacturers although the relationships were relatively informal; nothing concrete had yet been proposed in terms of working relationships, but the "network" was growing all the time.

It was "another world," a world circumscribed by regulation and preoccupied with competition. Bonneville was learning that the "culture" of manufactured housing is different from the site-built market and involves its own mysterious alphabet, including DAPIAs, IPIAs, and MHAs (see Box - The Industry's Private Language). As the project matured, the Technical Support Branch undertook bringing many of these players into the picture and began to establish a cooperative, information-sharing network of folks who were at least aware (if not always interested) in what new sreds were sprouting in the manufactured housi ig patch of Bonneville's energy conse rvation field.

A case in point was the pending test.

Because there were so many points of view, the Technical Support engineer who had initiated the project and piloted it through to this stage set up an unusual group to establish guidelines for the test. He called it the Criterion Formation Committee (CFC) and it included representatives from the Office of Conservation branches involved in the project. ${ }^{5}$ More significantly, it reached out to include members from the Council and the Farmer's Home Administration (FmHa). The Farmer's Home 


\begin{tabular}{|c|c|}
\hline \multicolumn{2}{|c|}{$\begin{array}{c}\text { THE INDUSTRY'S PRIVATE LANGUAGE } \\
\text { A Manufactured Housing Gloasary }\end{array}$} \\
\hline ANSI & American National Standards Institute \\
\hline ASHRAE & $\begin{array}{l}\text { American Society of Heating, } \\
\text { Refrigerating, and Air Conditioning } \\
\text { Engineers }\end{array}$ \\
\hline CDD & Cooling degree days \\
\hline CFR & Code of Federal Regulations \\
\hline DAPIA & $\begin{array}{l}\text { Design Approval Primary Inspection } \\
\text { Agency }\end{array}$ \\
\hline DOA & U.S. Department of Agriculture \\
\hline DOE & U.S. Department of Energy \\
\hline EIA & $\begin{array}{l}\text { U.S. Energy Information } \\
\text { Administration }\end{array}$ \\
\hline FHA & Federal Housing Administration \\
\hline FHLMC & $\begin{array}{l}\text { (Freddie Mac) Federal Home Loan } \\
\text { Management Corporation }\end{array}$ \\
\hline FmHA & Farmer's Home Administration \\
\hline FMHCSS & $\begin{array}{l}\text { Federal Manufactured } \\
\text { Housing Construction and Safety } \\
\text { Standard }\end{array}$ \\
\hline FNMA & $\begin{array}{l}\text { (Fannic Mac) Federal National } \\
\text { Mortgage Association }\end{array}$ \\
\hline HDD & Heating degree days \\
\hline HUD & $\begin{array}{l}\text { U.S. Department of Housing and } \\
\text { Urban Development }\end{array}$ \\
\hline IPIA & $\begin{array}{l}\text { Production Inspection Primary } \\
\text { Inspection Agency }\end{array}$ \\
\hline LPG & Liquid petroleum gas \\
\hline MBA & $\begin{array}{l}\text { Mortgage Bankers Association of } \\
\text { America }\end{array}$ \\
\hline MHA & Manufactured Housing Association \\
\hline MHI & Manufactured Housing Institule \\
\hline MHCSS & $\begin{array}{l}\text { HUD Manufactured Housing } \\
\text { Construction and Safety Standards }\end{array}$ \\
\hline MPS & Minimum Property Standards \\
\hline MSA & Metropolitan Statistical Area \\
\hline NAHB & National Association of Home Builders \\
\hline NBS & National Bureau of Standards \\
\hline NCSBCS & $\begin{array}{l}\text { National Conference of Statcs on } \\
\text { Building Codes and Standards }\end{array}$ \\
\hline NTIS & National Technical Information Service \\
\hline SAA & State Administrative Agency \\
\hline
\end{tabular}

Administration had just been legislated into a key role in financing manufactured housing for low-income families in rural areas.

When the RFP was complete, Bonneville sent copies to the building codes divisions of the four states in the region for their information, inviting participation and acknowledging the special experience many of these agencies had in manufactvred housing (experience that Bonneville lacked at that point).

During this period, Bonneville staff members visited a regional manufacturing plant to obtain a better understanding of plant operations, manufacturer concerns, and a firsthand look at one example of an energy-efficient model already being offered by the manufacturer in question. This tour was taken jointly by the Technical Support engineer and the Chief of the Consumer Products and Services Branch -- the branch responsible for developing a program for "marketing" new energy-efficient manufactured homes if (a) the test could be launched, and (b) results proved that the savings were cost-effective.?

Following the plant visit, Bonneville invited further dialogue and forwarded a SUNDAY analysis of the energy-efficient model, based on the following parameters:
- floor insulation R-22
- wall insulation R-24
- ceiling insulation R-33
- triple glazing $\quad \mathrm{R}-2.7$
- door insulation R-7.2

The natural infiltration rate was estimated at 0.85 air changes per hour $(\mathrm{ACH})$ and the internal heat gain (from appliances and people) was estimated at $3,000 \mathrm{Btu} / \mathrm{hr}$. Estimated energy use for this home located in Yakima, Washington, was 9,000 kWh per year. Later, additional estimates of $6,000 \mathrm{kWh} /$ year in Portland and 6,200 kWh/year in Salem were forwarded to the sales manager of the manufacturer. ${ }^{9}$

The interchange set the pattern for many more relationships that Bonneville would form with the region's manufactured housing producers, with manufacturers pointing out their capabilities and limitations and Bonneville articulating its objectives and demonstrating -first-hand -- what tools were available to 
quantify this abstract but important new energy resource known as "conservation."

\section{New Assignments}

As the calendar shifted from 1984 to 1985 , the manufactured housing project at Bonneville was formally moved from the Technical Support Branch to the Consumer Products and Services Branch. This move simply confirmed what had been clear for the past 6 months - it was becoming increasingly difficult to administer and manage the undertaking as a technical project. By now, clearly, it had become a program in development.

It stood out from other programs, however, because it retained its technical orientation. This was due to several factors: the technical nature of the federal standard, the technical aspects of the manufacturing process, and the technical orientatior of the new program manager who was transferred out of the Technical Support Branch to continue the work he had begun 18 months earlier when the retrofit study was begun. Besides creating a new program in development, this new assignment created somewhat of an anomaly at Bonneville -- a career Bonneville engineer was managing a conservation program!

So now the Bonneville project faced another world internally as well as externally. It acquired, first, a new designation, becoming known as the Energy-Efficient Manufactured Housing Test and Marketing Program. In early 1985 , the broad outlines of the program were circulated throughout Bonneville and subsequently throughout the region. Information was provided on the five major parts of the program:?

1. Performance Tests: BPA will purchase up to nine manufactured homes built to MCS energy requirements. This should demonstrate the industry's ability to design and build factor; units which are as energy-efficient as site-built homes. In addition the added cost of energy efficient methods can be determined. These homes should be delivered to BPA in October 1985, for a series of non-occupant tests. Later they will be sold to qualified buyers with the understanding that they are to be monitored for one year.

2. Market Analysis: BPA has modified an existing contract with Battelle's Pacific Northwest Laborator[y] to include a study of the paths and barriers faced by prospective manufactured home buyers of energy-saving options. Existing sources of information shall be researched and serve as the basis of a survey. The survey could include buyers, lenders, dealers, and manufacturers. A final report is due in June 1985.

3. Market Plan: BPA shall develop a plan to promote the manufacture and sale of energy-efficient manufactured homes under the Super Good Cents program. This work will be performed by a contractor using available data, reports, and other information needed to successfully launch a marketing program. The plan will include technical support and promotional activities that spell out suggested themes, budgets, and media mixes for different areas in the Pacific Northwest.

\section{Super Good Cents for Manufactured} Homes: Beginning in FY [fiscal year] 1987, the Super Good Cents Program should include energy-efficient manufactured homes. Contracts will be offered to media and other marketing agents based on prudent and informed marketing decisions.

5. Public/Private Involvement: $B P A$ will coordinate its activities with all federal, state, local, public, or private organizations interested in promoting the design, construction, or sale of energyefficient manufactured homes. To date we have included in our plans: 
Northwest Power Planning Council, U.S. Department of Energy, Farmer's Home Administration, Western Manufactured Housing Institute, Oregon Department of Commerce (Building Codes Division), Washington Department of Labor and Industries (Factory Assembled Structures). This is an ongoing effort and no completion dates are expected.

\section{Pacific Northwest Laboratory}

Throughout the preceding summer, the Planning Branch had continued its investigation of the potential of manufactured housing somewhat independently. At this point, there was broad agreement that the housing category represented a major source of energy savings that the region could not afford to overlook. It also supported the growing realization of the program managers that there was simply too much to learn for Bonneville to "go it alone." Help was needed to learn more about the industry, about the characteristics of the region's manufacturers, about the manufactured home customer. It was "another world."

The Pacific Northwest Laboratory (PNL) was a logical source of help. In fact, PNL had already been involved in the project in two ways. First, it was PNL that forged the initial contact between the DOE, HUD, and the Bonneville staff. PNL was working on contracts with both the DOE and HUD that involved the eventual upgrade of the Federal Manufactured Housing Construction and Safety Standard -- one of its tasks was to help HUD determine cost-effectiveness with more accuracy. Second, PNL was already working with Bonneville's Division of Planning and Assessment, chiefly on assessment issues.

In an unusual move, at the highest levels, Bonneville shifted its priorities to bring PNL's resources to bear on the manufactured housing opportunity. It was a move in line with others that had taken place, oriented to the future and the development of capabilities. Rather than investing funds in assessing results, Bonneville decided to invest in assessing potential. It was a new tack for Bonneville - and a new tack for PNL as well.

\section{PACIFIC NORTHWEST LABORATORY (PNL)}

Pacific Northweat Laboratory (PNL) is a national multiprogram laboratory operated for the U.S. Department of Energy (DOE) by the Pacific Northwest Division of Battelle Memorial Inatitute. Headquartered in Columbus, Ohio, Buttelle is composed of technology experts, engineers, and support specialists who assist industry and government in developing, commercializing, and managing technology. Battelle has a world-wide staff of over 7,500 and serves clients in over 30 countries,

Battelle's PNL is loculed in Richland, Washington, and has a staff of over 3,500. Bccause so many of the region's energy issues involve the Bonneville Power Administration, directly or indirectly, PNL maintains an office in Portland as well. PNL conducts a variety of research work for DOE and numerous other governi. snt agencies. At the time of this report, PNL was working on manufactured housing issues for the DOE and HUD.

By 1983-84, Bonneville had become a major client of PNL. Bonneville was engaged in the most comprehensive, most extensive energy conservation project in the country (if not the world) and began drawing upon the research and development skills that PNL could provide. PNL was helping Bonneville to develop the new research tools needed to measure energy use, energy-saving potential, and cost-effectiveness. It also helped Bonneville assess the environmental impacts of energy conservation and other measures.

Bonneville and the region had begun to look to PNL to develop techniques to determine elusive matters of fact, to measure everything from air quality to consurner reactions, and to report its findings in objective and accurate reports.

\section{Super Good Cents}

The manufactured housing project was nothing if not adaptive. It made use of existing resources wherever they could be found -- there was no reinventing of the wheel. The EnergyEfficient Manufactured Housing Test and Marketing Program overview had outlined plans to market new manufactured homes as part of 
Bonneville's new Super Good Cents program. ${ }^{7}$ Actually, this program was as much in development as the manufactured housing project - in fact they were "growing up" together.

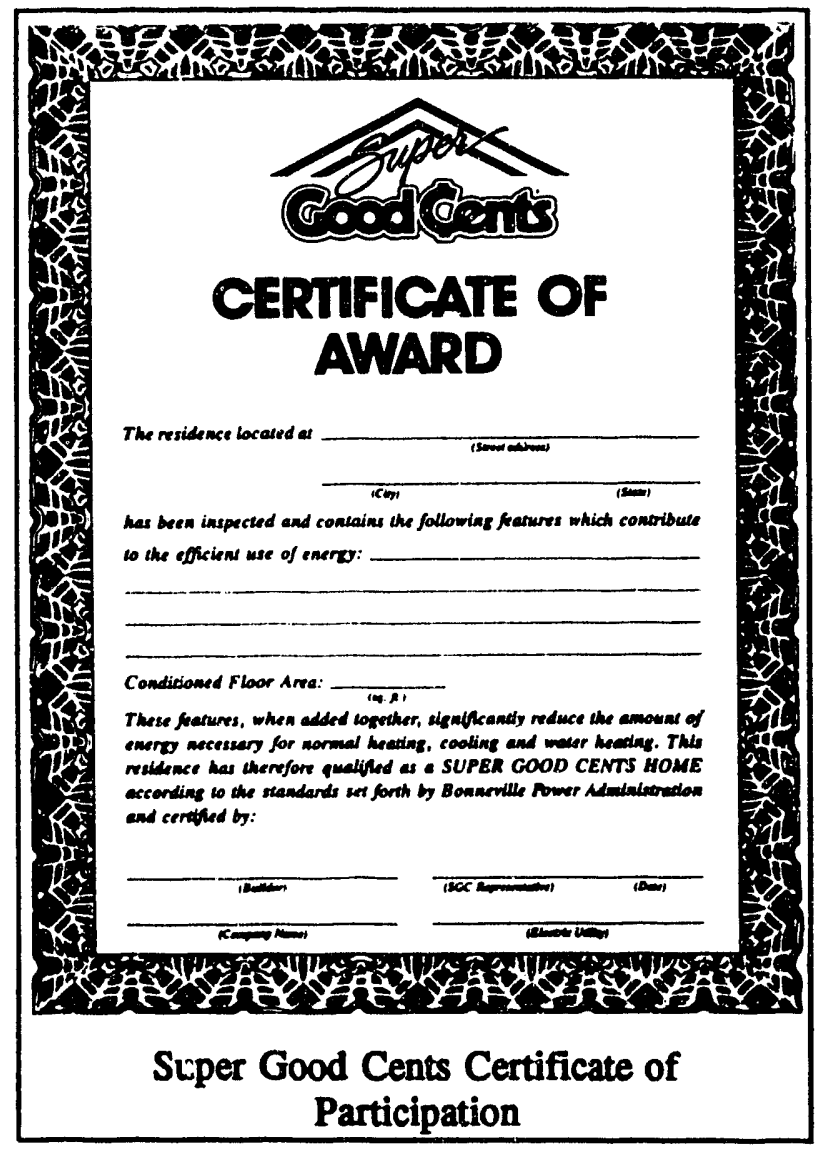

When it became clear to the region's energy planners that the MCS would not be immediately adopted as code by either the states or local jurisdictions, the Council and Bonneville embarked on an effort to encourage the construction and sale of energy-efficient housing directly to the consumer. Such a direct marketing effort would address the concern that opportunities to conserve energy would be lost in the interim between the issuance of the MCS and their adoption.

Needing a mechanism to encourage conservation, in 1984 Bonneville purchased rights to a utility program for energy-efficient new homes called GOOD CENTS from Southern Electric International. Bonneville modified the program, calling it Super Good Cents (SGC). Through Super Good Cents, Bonneville planned to offer promotional and technical materials to utilities - as well as funds for cooperative advertising and marketing. Participating utilities, using a computer modeling program called WATTSUN, would certify homes as meeting the Super Good Cents specifications, which would be based on MCS.

Development and management of the Super Good Cents program was being managed by the Consumer Products and Services Branch -- the same branch into which the manufactured housing program had been shifted. This ensured that both programs would be coordinated. One of the first tasks was to determine, via market analysis conducted by PNL, whether manufactured homes could in fact be sold in this manner and then to develop a strategy for doing so.'

\section{And Indians Too}

By now, Bonneville was "in the loop." Virtually anything that had the words "manufactured housing" or "mobile hornes" on it somehow found its way to the manager of the manufactured housing project at Bonneville. Early in 1985, Bonneville learned that HUD was planning to assist the Tulalip Housing Authority in providing approximately 35 new single-family homes to the Tulalip Indian Reservation near Marysville, Washington. Bonneville learned that because of budget constraints, HUD was considering manufactured homes to meet this need. ${ }^{10}$

With the Tulalip housing project, Bonneville saw an opportunity to learn more about the energy performance of manufactured homes built to the MCS than it could from the ninehome demonstration in the works. For the relatively low cost of the upgrade to the MCS (estimated at about \$2-\$3 per sq.ft.) Bonneville could gain experience with the specifications, possibly collect monitored data, and achieve visibility for the Super Good Cents program applied to manufactured homes. ${ }^{10}$ It seemed to 
be a perfect opportunity to mesh the needs of the Tribe, of HUD, and of Bonneville. The light was green. Bonneville management agreed to the investment. Win-win-win.

*******
By mid-1985, almost everything that could have been done to learn more about the world of manufactured housing had been done. Mechanisms were in place to begin to collect the kind of meaningful data the project required.

\section{End Notes}

1 Internal memorandum on mobile homes from the Chief of the Planning Branch (KEP) to the Chief, Technical Support Branch (KTT) via the Director, Division of Planning and Evaluation (KE). June 15, 1984. Bonneville Power Administration, Portland, Oregon.

2 Internal memorandum on new mobile/ manufactured (M/M) home cost benefit analysis from the General Engineer (KTT) to the Chief, Marketing Support Branch (KTM). June 22, 1984. Bonneville Power Administration, Portland, Oregon.

3 Internal memorandum on the work statement for a manufactured home cost demonstration program from the General Engineer (KTT) to the Chief, Marketing Support Branch (KTM). July 18, 1984. Bonneville Power Administration, Portland, Oregon.

4 Internal memorandum on the long-term monitoring of energy-efficient manufactured homes from the General Engineer (KTT) to the Director, Residential Programs Division (KT) via the Chief, Marketing Support Branch (KTM). November 5, 1984. Bonneville Power Administration, Portland, Oregon.

5 Internal memorandum on the introduction of members and the announcement of the first CFC meeting (November 14, 1984) from the General Engineer (KTT) to members of the Manufactured Housing

Criterion Formation Committee (CFC). November 5, 1984. Bonneville Power Administration, Portland, Oregon.

6 Letter from the General Engineer (KTT) to the Administrators, Building Codes (Idaho, Montana, Washington, and Oregon). December 5, 1984. Bonneville Power Administration, Portland, Oregon.

7 Letter on the energy-efficient manufactured housing test and marketing program from the Director, Division of Residential Programs, to the Manufactured Housing Project Mailing List. February 11, 1985. Bonneville Power Administration, Portland, Oregon.

8 Letter from the Manufactured Housing Project Manager to the Sales Manager, Silvercrest Industries, Inc., Woodburn, Oregon. February 26, 1985. Bonneville Power Administration, Portland, Oregon.

9 Letter from the Manufactured Housing Project Manager to the Sales Manager, Silvercrest Industries, Inc., Woodburn, Oregon. March 14, 1985. Bonneville Power Administration, Portland, Oregon.

10 Internal memorandum on the joint effort with HUD/Homes for the Tulalip Indian Tribe from the Manufactured Housing Program Manager (KRP) to the Director, Division of Residential Programs (KR). April 22, 1985. Bonneville Power Administration, Portland, Oregon. 


\section{CHAPTER 6: TIGHTENING THE FOCUS -- Hard Data, Firm Marketing Plans}

Inexorably, from early 1985 onward, Bonneville's exploration of the energy-saving potential of the region's manufactured homes moved deliberately, albeit slowly, to a finer resolution, a clearer focus. Organizationally, the project was now defined as a marketing support program in development. It was no longer a simple technical investigation; the argument that manufactured homes would become a significant part of the region's future housing stock that perhaps could generate significant energy conservation resources was gaining more and more credibility. In fact, many of the branches in Bonneville's Office of Conservation were involved in the undertaking.

This included the Planning Branch, which is involved with long-term planning for the Division of Planning and Evaluation. Because the penetration and energy-saving potential of manufactured homes was so great, the division had agreed to modify its inter-agency agreement with PNL so that these major regional research and evaluation resources could be brought to bear on the manufactured housing issue. At the highest levels, Bonneville's managers agreed that PNL's abilities could be better invested in "tightening the focus" on manufactured housing than in any other planning or assessment activity. This brought the Planning Branch and the Consumer Products and Services Branch into a rather uncommon but productive alliance, with the Planning Branch now, in effect, helping to focus program development.

In 1985, Bonneville was driven by priorities in all sectors -- commercial, industrial, and residential. Because the residential standards were further developed, much of Bonneville's emphasis was on programs to support new sitebuilt (the commonly used term to describe these homes was "stick-built") residential construction to the MCS. Bonneville efforts included the Residential Standards Demonstration Project
(RSDP), translating the MCS into "code language" - the Northwest Energy Code (NWEC), and Code Early Adopter programs to encourage local jurisdictions to adopt the NWEC as an energy standard within the local building code. Because the HUD code would preempt applying these efforts in the manufactured housing sector, Bonneville saw a clear need to develop alternate mechanisms to bring these homes into any long-term conservation strategy.

\section{The Plan - Bonneville's Overview}

The Energy-Efficient Manufactured Housing Test and Marketing Program was therefore designed as a specific means of bringing HUD code manufactured homes into the "big picture." As noted, since 1976 these homes had been built to HUD code standards, also known as the Federal Manufactured Home Construction and Safety Standards. The code's Subpart F - Thermal Protection established a maximum allowable Transmission Heat Loss Coefficient $\left(U_{0}\right)$ for these homes. The code established three climate zones for which the value of $U_{0}$ was specified -- the Pacific Northwest fell into HUD's climate zone II.

For HUD's climate zone II, the specified $U_{0}$ was $0.126 \mathrm{Btu} /(\mathrm{hr})\left({ }^{\circ} \mathrm{F}\right)(\mathrm{sq} . \mathrm{ft}$.). This was a minimum thermal protection requirement, translating to about $R-11$ levels of insulation in the floor and walls, R-14 in the ceiling, and double glazing (Onisko 1985). Minimal as these standards were, it should be noted that in the mid-1970s, any energy standard was the exception rather than the rule. As we have seen, the situation differed somewhat in the Pacific Northwest where many manufactured housing producers had evidently long built homes to an ANSI standard that somewhat improved levels of energy efficiency. In addition, most regional manufacturers offered 


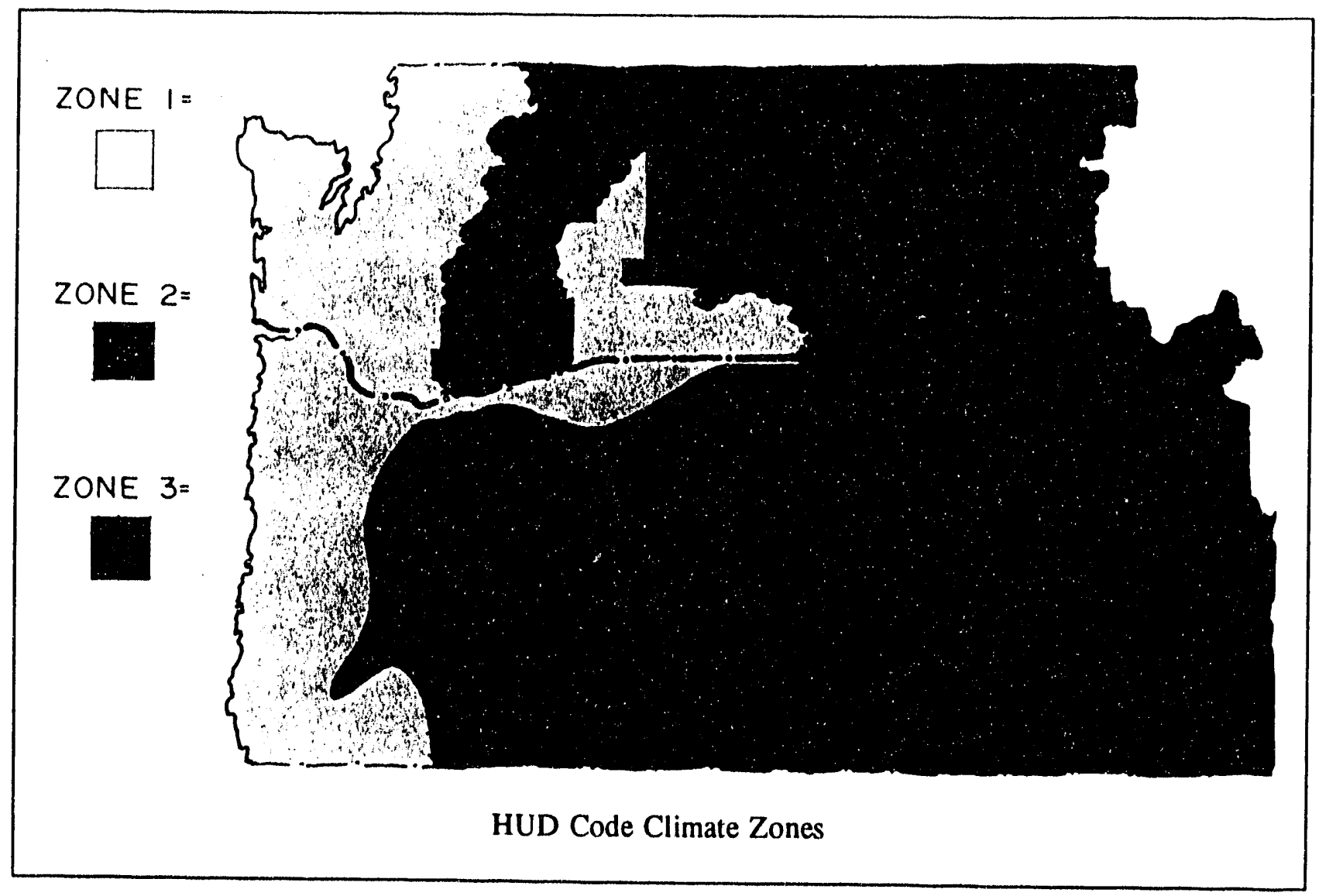

buyers some sort of energy-savings package at an added cost, although manufacturers had indicated that these homes were not much in demand or sold in much quantity.

The MCS for site-built homes far exceeded the HUD code requirement. The MCS would require insulation levels of approximately $R-19$ in the floor, R-27 in the walls, and R-38 in the ceiling, as well as triple-glazing. Bonneville estimated that approximately a one-half to twothirds reduction in energy consumption could result from building manufactured homes to these MCS standards (Onisko 1985).

Because nearly all HUD-code homes sold in the Pacific Northwest were heated electrically, the estimated penetration rates for these homes did not illustrate the true impact of manufactured housing in terms of their effect on electric usage. Using figures showing the electric space heating penetration rates for new homes that Bonneville had developed, the program staff circulated a more informed view of the situation, shown in Table 6.1 (Onisko 1985).

In early 1985, Bonneville's Planning Branch was concerned that the agency's long-term residential sector forecast developed by the

TABLE 6.1 - Pacific Northwest Mobile Home New Construction, Medium Case (thousands)

\begin{tabular}{|l|l|l|l|}
\hline & 1985 & 1990 & 2005 \\
\hline $\begin{array}{l}\text { New HUD-Code } \\
\text { Homes }\end{array}$ & 14.25 & 14.29 & 18.10 \\
\hline $\begin{array}{l}\text { \% New } \\
\text { Construction }\end{array}$ & 17.6 & 18.6 & 21.5 \\
\hline
\end{tabular}


Economic Studies and the Energy Analysis Sections of the Office of Power Sales understated the number and share of new mobile homes over the 20-year planning horizon. The estimates were reviewed; the final forecast results are shown in Table 6.2.

The review also revised thermal integrity values calculated for manufactured homes, acknowledging that new homes were better insulated than the current stock. The estimated number of HUD code homes using electric heat remained in question -- the Office of Conservation used higher estimates for electrically heated home penetration than did Bonneville's economic forecasters.

\section{Thermal Performance}

A field trip early in 1985 would provide some of the first "real-world" data on the actual energy performance of manufactured homes. Perhaps most important, it would verify that the analytical model to assess energy performance that Bonneville's efforts had created was both accurate and workable. The field trip was to Springfield, Oregon, where the manufactured housing project had "inherited" a venture from the period when the retrofit study was first proposed.

At that time (1983), prior to the change in the direction of Bonneville's conservation activity as a result of the Act, the Technical Support Branch was exploring solar hot water heating as a conservation option. As part of this effort, a manufactured home had been sited in Springfield, Oregon, in December 1984. Built to the Federal Manufactured Housing Construction and Safety Standard, the home was constructed to achieve the HUD standard, a maximum overall Transmission Heat Loss Coefficient $\left(\mathrm{U}_{\mathrm{o}}\right)$ of $0.126 \mathrm{Btu} /(\mathrm{hr})\left({ }^{\circ} \mathrm{F}\right)$ (sq.ft.) and used its passive solar heated water tank to increase the home's thermal mass and help reduce its annual heating load. The house was sited to obtain maximum solar gain and minimum shading (Onisko and Ek 1985).

TABLE 6.2 - Estimated 1983 Single-Family (1-4 unit) Electrically Heated New Home Sales

\begin{tabular}{|c|c|c|c|c|c|c|}
\hline \multirow[b]{2}{*}{ State } & \multicolumn{3}{|c|}{ Total Home Sales } & \multicolumn{3}{|c|}{ Electrically Heated Home Sales } \\
\hline & $\begin{array}{c}\text { All } \\
\text { Home } \\
\text { Sales }^{(0)} \\
\end{array}$ & $\begin{array}{c}\text { HUD code } \\
\text { Home } \\
\text { Sales }^{(b)} \\
\end{array}$ & $\begin{array}{l}\text { HUD code } \\
\% \text { Of } \\
\text { Market } \\
\end{array}$ & $\begin{array}{c}\text { Estimated } \\
\text { Electric Heating } \\
\text { Penetration } \\
\text { Rate } \\
\end{array}$ & $\begin{array}{c}\text { Estimated } \\
\text { Electrically } \\
\text { Heated } \\
\text { Homes } \\
\end{array}$ & $\begin{array}{c}\text { HUD Code } \\
\% \text { of } \\
\text { Electrically } \\
\text { Heated Homes } \\
\end{array}$ \\
\hline OR & 9,554 & 2,600 & 27.4 & 47.0 & 4,490 & 57.9 \\
\hline WA & 25,582 & 6,000 & 23.7 & 54.8 & 14,020 & 42.8 \\
\hline ID & 5,364 & 1,700 & 32.9 & 48.3 & 2,590 & 65.6 \\
\hline $\begin{array}{l}\text { West. } \\
M T^{(c)}\end{array}$ & 2,861 & 700 & 25.4 & 40.3 & 1,150 & 60.9 \\
\hline TOTAL & 43,361 & 11,000 & 25.8 & & 22,250 & 49.4 \\
\hline $\begin{array}{l}\text { (a) } B \\
\text { (b) } \quad H \\
\text { (c) } E \\
\text { Source: }\end{array}$ & $\begin{array}{l}\text { d on LS } \\
\text {-Code s } \\
\text { nated at } \\
\text { inisko } 15\end{array}$ & $\begin{array}{l}\text { ystems, } 19 \\
\text { s are round } \\
\text { alf of Monta } \\
5\end{array}$ & $\begin{array}{l}\text { down to } t \\
\text { statewide }\end{array}$ & $\begin{array}{l}\text { nearest } 100 . \\
\text { les. }\end{array}$ & & \\
\hline
\end{tabular}


Early in 1985, assisted by Bonneville's Division of Laboratories, the Office of Conservation arranged for a series of tests to determine:

- the home's heat loss rate, and from this its estimated annual electric heating requirements, both with/without the passive solar features in operation

- the infiltration rate of the home based on a blower door test (see Box - Measuring Air Leakage).

Because it was built to the HUD code, the home provided an excellent opportunity to compare its actual overall heat loss with the HUD standard. It also provided an opportunity to test the analytical model developed by the Office of Conservation (Onisko and Ek 1985).

\section{MEASURING AIR LEAKAGE: The Blower Door Teat}

Homes are measured for leakiness using a device known as a "blower door." A "door" containing a large fan and openings is fitted to the front or back door of a home and all other doors and windows are shut and sculed with duct tape. The fan is then tumed on and the house is depressurized by forcing air out through the blower door opening.

This creates a pressure gradient, causing air to enter the home through "natural" leakage paths in the structure. By carefully controlling the fan speed, and measuring a series of pressure gradients, an accurate estimate of the home's leakage can be developed. Analysis yields a measure of the home's equivalent leakage area, a single area equal to the sum of all the small leakage areas in the home at 0.16 inches of water, and a 4 Pascal $(\mathrm{Pa})$. pressure drop between the interior and exterior of the home.

Analysis also provides an estimate of the "natural" air exchange rate of the home expressed in air changes per hour.

With the passive solar features of the house disabled, energy usage in $\mathbf{k W h}$ was measured over a 12-hour period during which the average difference between outside/inside temperature was $38.19^{\circ} \mathrm{F}$. This yielded a heat loss rate of 376.1 Btu/(hr) $\left({ }^{\circ} \mathrm{F}\right)$, which when divided by the home's total wall, floor, and ceiling area $(3,441$ sq.ft.) resulted in a $U_{0}$ of $0.1093 \mathrm{Btu} /$ $(\mathrm{hr})\left({ }^{\circ} \mathrm{F}\right)$ (sq.ft.). Using the same data, the analytical model yielded very similar values -- a heat loss rate of 379.0 and $a U_{0}$ of 0.1102 . The home performed better than the HUD code requirement and the correlation between "realworld" results and the model was excellent (Onisko and Ek 1985).

The blower door test revealed that the home was about average in terms of air leakage. No air leaks were observed along the wall/floor junction, indicating that the factory technique effectively sealed the bottom plate. Major leaks were detected along the "marriage line" (the junction between the two halves of a doublewide manufactured home) - this finding was to bear importantly on the development of specifications much later in the project (Onisko and Ek 1985).

The solar performance aspects of the home were disappointing; the house simply failed to live up to its design potential. Researchers expected the solar features to effect a $30 \%$ reduction in energy use, but the test data revealed that only about $8 \%$ savings could be generated under the most favorable conditions. However, the use of this "orphaned" test to verify HUD code performance and analytical model development is another example of how the project made resourceful use of data opportunities from a wide variety of sources and serendipity again at work!

\section{Defining the Terms}

One problem that surfaced frequently was confusion about the terms and definitions of manufactured housing. The terms used were not consistent; initially Bonneville called the homes "mobile homes," a term subsequently amended to mobile/manufactured (or M/M) homes. The National Association of Home Builders had reported that, "builders, bankers, 
and customers were confused on the difference between the true modular home and the HUD code (mobile) home."

Once and for all, the proper terms were established by the Bonneville project manager in a definitive document circulated in mid-1985. Four types of manufactured homes were listed and their characteristics and proper terms were briefly defined. ${ }^{3}$

Prefab - Also called pre-cut homes, these homes are delivered to the site as pre-cut pieces of wood (except for roof trusses, windows, and doors) with a set of instructions. Built under state and local codes, this category represents a small share of the market.

Panelized (two dimensional) - Most parts are delivered as flat wall, floor, and ceiling sections with windows and doors sometimes already installed. Assembly usually requires a crane. These homes are also built to state and local codes.

Modular (three dimensional) - Usually these homes are delivered in a cubical form and assembled on site; the number of cubes may vary from one to several. These homes are built to state and local codes as well.

HUD Code Manufactured (three dimensional) This is also known as the "mobile" home. These homes are built under Title VI of the Housing and Community Development Act of 1974. Congress instructed HUD to establish a federal enforcement and standards program for these homes and in 1976 HUD promulgated the Federal Manufactured Housing Construction and Safety Standard. In 1982, Congress changed the word "mobile" to "manufactured," reserving the term "mobile" to refer only to recreational vehicles. Most states, trade magazines, trade associations, and others have since used the term "manufactured homes" to define HUD code homes.

\section{Marketing Developments}

In the summer of 1985, PNL completed the draft of its first study for the Bonneville project: "Marketing Energy Conservation Options to Northwest Manufactured Home Buyers" (Hendrickson et al. 1985a). This study used available source material to provide background information that would be valuable in designing a marketing plan to achieve energy savings in new manufactured homes. In the document summary, PNL presented several key findings (see Box - PNL 1985 Market Study).

PNL emphasized that the study did not provide a marketing program, it was merely an assessment and review of available background in a framework necessary to begin that process. PNL felt that "targeting based on consumer characteristics should be a major consideration." It also stressed that dealers appear to play a significant role in consumer decision-making and that, accordingly, dealers should be given information about customers' views and should be included in any marketing program. Significantly, PNL concluded its overview by stating (Hendrickson et al. 1985b):

Available information suggests that the manufactured homes sector represents a significant and unique target for energy conservation marketing and, through a well-designed program, could provide energy savings not likely to occur otherwise, while benefiting the occupants of nearly one third of new single-family housing.

The study was extremely comprehensive; perhaps one of its most beneficial features was the organization of several diverse investigations and sources of information into one cohesive document. It would serve as a frame of reference for years to come and it established the general approach that would be followed in further marketing activities. One 


\section{INI, 1985 MAKKE'I S'IUDY: IIIGIIIGII'S}

- Important differences exist between manufactured and site-built homes and between their occupants.

- Northwest regional characteristics also differ in importunt ways from national characteriatics.

- Nearly half of Pacific Northweat manufactured homes are located in the high heat load areas cast of the Cascades (compared to about one-third of aitobuilt homes).

- Nearly two-thirds of manufactured homes are in rural areas compared to only about $40 \%$ of sitc-built homes.

- While manufactured homes constitute about $10 \%$ of the region's single-family housing stock, they constituted over $25 \%$ of the additions to the same slock in 1984.

- Over half the manufactured homes sold in the Pacific Northwest were double-wide homes whereas the national figure was closer to 20\%. Double-wide homes are likely to cost more and consume more energy than single-wide homes.

- Manufactured homes in the Pacific Northwest are more likely to have clectric space heating than sitebuilt homes but both types of homes have shown an increasing use of wood for space heating.

- About two-thirds of Northwest manufactured home occupants have no college education whereas only about $45 \%$ of site-built home occupants have none.

- Manufactured home houscholds typically have incomes below those of site-built houscholds.

- Northwest manufactured home occupants tend to be below 35 or over 55 more often than site-built home occupants.

key phrase from the study, in a section discussing harriers to investing in extra-cost energy conservation measures, stated (Hendrickson et al. 1985b):

A certification or labeling program such as the Super Good Cents program can potentially aid the process of providing the consumer with understandable energy efficiency information.
The study was generally well received, but not without controversy. When the study was forwarded to the Manufactured Housing Institute (MHI), a trade association, for comment, the MHI disagreed sharply with PNL's conclusions regarding cost-effectiveness of various packages." "With the uniquely low cost of electricity in the region, it takes a great stretch of imagination and of economic assumptions, to reach such conclusions. We vehemently disagree!" The MHI also took issue with PNL's finding that manufactured home buyers differed substantially from sitebuilt home buyers in terms of education and income.

The MHI struck a note that was to be heard again and again throughout program development -- from the industry, from HUD, even from some utilities. The combination of the region's extremely low electric rates and the relatively high cost of mortgage money for manufactured home buyers did, in fact, often make cost-effectiveness difficult to achieve for consumers. What these critics overlooked was that energy efficiency might well be costeffective for the region's utilities when compared to their cost of acquiring new power resources to heat large numbers of inefficient manufactured homes. Then, the cost of power would not be so low in the Northwest -- but the opportunity to avoid the investment would have been lost. This issue of cost-effectiveness for the consumer versus cost-effectiveness for the region would outlast nearly every other concern, every other issue.

Bonneville's Planning Branch also disagreed with some of the study's findings. Like the MHI, the planners did not believe that the data supported the notion that manufactured housing buyers represented a unique market segment. ${ }^{4}$ Further research among potential home buyers was suggested as a possible solution. Many of the Planning Branch comments were more related to the relative value of various means of achieving energy savings. While this was a very real concern of everyone connected with the study, it was agreed to be outside the scope 
of the initial effort. The study was merely the raw material for a strategic marketing plan addressing these issues, one that Bonneville would request of a Portland firm -- Wagner, Wiecks, Smith \& Lapel (WWS\&L) -- that same summer. ${ }^{5}$

\section{Reviewing the Situation}

By mid-summer of 1985 , all actions to date had tended to confirm the course that had been set for manufactured housing. The RFP for the demonstration homes had been finalized. By now the number of homes had been reduced to nine. In one sense, response to the RFP was good. Bonneville's project management had kept everyone "in the loop," and state building officials, DOE, HUD, and other Bonneville divisions and branches had provided input into the final specifications for the demonstration homes. But in another sense -- a key one -response was disappointing. The region's manufacturers appeared to be slow, perhaps reluctant to respond to the RFP.

But the "game plan" was set and reconfirmed. Once tested so that the energy savings and costs could be determined, new manufactured homes would be marketed under the Super Good Cents program now being introduced for site-built homes. In a note to the Assistant Administrator for Conservation, the Chief of the Consumer Products and Services Branch estimated that by December 1989, up to $25 \%$ of manufactured homes would be sold as a Super Good Cents home (built to MCS). ${ }^{6}$

The biggest change in plans occurred when the Council issued its draft 1985 Conservation and Electric Power Plan for the region (NWPPC 1985). The draft plan suggested that a regional marketing and financial incentive program for manufactured homes be introduced into Bonneville's planning strategy. So far so good. What was a concern was the goal set by the Council -- 50\% market penetration by July 1990. While Bonneville had taken the initiative in manufactured housing and its progress was encouraging, the sudden and ambitious goal set by the Council was troubling. It was doubtful that such a goal could be achieved, even with the "head start" that had been achieved. What was not doubtful was that it was a "budget buster."

Bonneville's project management had calculated the estimated regional sales of manufactured homes over the next 5 years (see Table 6.3). ${ }^{7}$ Relying on a statistical tool called the logistic function, a growth curve that estimates the size of any given population over time, Bonneville had calculated a year-by-year estimate of manufactured homes sold as Super Good Cents homes based on the $25 \%$ penetration goal that had been set internally for the project. When the logistic function was altered to reflect a $50 \%$ penetration goal, the numbers increased accordingly.

Estimated costs for the escalated goal were likely to increase sharply, partly due to an estimated $40 \%$ increase in the administrative, education/training, inspection, and other program support, but also due to the addition of a per-home financial incentive (estimated for planning purposes at $\$ 1,000$ per home).

Bonneville's present budget for the projected program would nearly double in the near-term (1 to 2 years) and increase ever more sharply to more than 7-fold levels at the end of the 5-year budget period (see Table 6.4).

At this point in time, the Council's plan was only a draft. The Council's enthusiasm and support was welcome, but it sure had its price! It was also extremely overly optimistic because at this stage, lacking "real world" experience, it would be extremely difficult to know what the specifications for energy-efficient manufactured homes would be. There were no available data to determine which energy conservation measures were cost-effective for manufactured homes.

As a practical matter, Bonneville continued the development of the program on several fronts: 
TABLE 6.3 - Estimated Regional Manufactured Home Sales by Year ${ }^{(\mathrm{a}) 7}$

\begin{tabular}{||l|c|c|c|c|c||}
\hline \hline State & 1986 & 1987 & 1988 & 1989 & 1990 \\
\hline OR & 2,856 & 2,942 & 3,030 & 3,121 & 3,215 \\
\hline WA & 6,624 & 6,823 & 7,028 & 7,239 & 7,456 \\
\hline ID & 1,928 & 1,986 & 2,046 & 2,107 & 2,170 \\
\hline West. MT & 793 & 817 & 842 & 867 & 893 \\
\hline TOTAL & 12,201 & 12,568 & 12,946 & 13,334 & 13,734 \\
\hline (a) Based on LSI Systems data. \\
\hline
\end{tabular}

- acquiring the demonstration homes and developing a test plan

- commissioning PNL to further study marketing issues, specifically the plan to market manufactured homes under the Super Good Cents program

- siting and testing 34 manufactured homes built to the MCS on the Tulalip Indian Reservation in cooperation with HUD

- exploring the licensing requirements and options of marketing manufactured homes under the Super Good Cents umbrella.

\section{Demonstration Homes}

Bonneville's RFP for nine demonstration homes had been mailed to all regional manufacturers in late spring 1985. There were no "takers." Perhaps this was not surprising. It required, after all, a great deal of effort to modify production lines and the RFP was a complex document, loaded with government purchasing legalese, terms and conditions, and dire penalties for non-performance. And all for only nine homes! In hindsight, the failure of manufacturers to respond is not surprising; at the time, Bonneville may not have known enough about the industry to recognize that the RFP had managed to combine two of the least attractive situations for the typical manufactured housing supplier: (a) unknown special conditions that require tampering with smoothly operating production lines, and (b) customized, one-time sales -- "one-offs" in industry jargon.

Finally, Bonneville solicited the assistance of an industry consultant, The Levy Partnership, Inc. (TLP). With its more intimate contacts with the industry, TLP was able to persuade Glen River Industries -- a regional manufacturer who tended to customize more of its product than others -- to build the demonstration homes to TLP's design modifications. TLP's involvement was critical in several ways. For example, TLP was able to bridge the communication gap between Bonneville and the industry. It translated Bonneville's specifications into the industry's actual plant processes and (since TLP would be the contractor) saved the manufacturer from having to become directly involved with the pages and pages of terms and conditions.

With Glen River Industries' cooperation assured, TLP developed a proposal that was accepted by Bonneville in the fall of 1985 . The proposal agreed to building a total of five homes to the MCS. Three of these, in varying sizes, were to be built to the specifications for climate zone 1, delivered and sited at Bonneville's Ross Complex in the mild maritime climate of Vancouver, Washington. Two homes were to be built to more demanding specifications -- one to climate zone 2 and one to climate zone 3 . These were to be delivered to the region's climatologically tougher "inland 
TABLE 6.4 - Budget Comparisons (50\% versus $25 \%$ manufactured housing penetration goals) (in thousands of dollars)

\begin{tabular}{|c|c|c|c|c|c|}
\hline & FY1986 & FY1987 & FY1988 & FY1989 & FY 1990 \\
\hline BPA (FTE) & $\$ \quad 38.5$ & 38.5 & 38.5 & 38.5 & 38.5 \\
\hline Travel & 8.) & 8.0 & 9.0 & 10.0 & 10.0 \\
\hline Contracts & 377.2 & $1,310.0$ & $1,000.0$ & $1,000.0$ & $1,000.0$ \\
\hline Incentives ${ }^{(0)}$ & 50.0 & 590.0 & $1,295.0$ & $3,587.0$ & $6,867.0$ \\
\hline $\begin{array}{l}\text { TOTAL (50\% } \\
\text { Objective) }\end{array}$ & $\$ 669.0$ & $\$ 2,513.0$ & $\$ 2,790.0$ & $\$ 5,084.0$ & $\$ 8,364.0$ \\
\hline $\begin{array}{l}\text { Present } \\
\text { Budget }\end{array}$ & 423.7 & $1,356.5$ & $=1,047.5$ & $1,048.5$ & $1,048.5$ \\
\hline $\begin{array}{l}\text { INCREASED } \\
\text { BL DGET }\end{array}$ & $\$ 245.3$ & $\$ 1,156.5$ & $\$ 1,742.5$ & $\$ 4,035.5$ & $\$ 7,315.5$ \\
\hline $\begin{array}{ll}\text { (a) } & \text { Finar } \\
\text { FTE } & =\text { full-ti } \\
F Y & =\text { Fisca }\end{array}$ & $\begin{array}{l}1 \text { incentives } \\
\text { engineer } \\
\text { ear }\end{array}$ & mated at \$ & 0 per energ & ient home. & \\
\hline
\end{tabular}

empire," represented by PNL's facilities at Richland, Washington.

These five models would not be the only demonstration tiomes available ior analysis by Bonneville. After nearly a year of negotiating and buttoning down detail after detail, an additional 34 manufactured homes were being built to the MCS by Silvercrest, another Northwest manufacturer, under contract to HUD. These homes would be sited on the Tulalip Indian Reservation early in 1986 and yield real-world -- and very encourdging -results.

\section{Super Good Cents}

A tentative plan had been developed to broadly market the energy-efficient manufactured homes under the Super Good Cents program Bonneville had recently deveioped to promote residential energy savings in the larger, more predominant site-built sector. Among other activities, the manufactured housing project group initiated correspondence with the licensing agent for the Super Good Cents program to ensure that manufactured homes could be included iil Bonneville's final program. ${ }^{8}$ Advance appioval was obtained although the licensing agent rejected an idea to identify manufactured homes in some special way. (One suggestion was to show an I-beam under the Super Good Cents logu.)

PNL's first task after completing the initial marketing background study was to determine how HUD code manufactured homes could be included in the existing Super Good Cents program. The draft of this report, "Marketing Manufactured Housing Under the "Super Good Cents Program" (Mohler and Smith 1986), was delivered late in 1985 . While the report dealt most importantly with the options available for including manufactured homes in the Super Good Cents program, it included other material as well (Mohler and Smith 1986):

- a description of the Super Good Cents program 
- characteristics of manufactured home consumers

- characteristics of the manufactured home market

- recommendations and options for the inclusion of manufactured homes in the Super Good Cents program.

None of the collateral information was new or novel, nor was it intended to be. The managers at Bonneville for whom the report was written knew from the previous PNL study, for example, what the characteristics of the manufactured home market and consumer were. Most of them, because many were connected with the Consumer Products and Services Branch, knew the broad outlines of the Super Good Cents program. But by including this background information, the report served as a "stund-alone" document with all pertinent information in one place.

The strategy proposed by PNL was designed to (a) reduce risks to manufacturers, dealers, and consumers, (b) stimulate demand, and (c) allow for maximum flexibility. Specific program strategy features included the following (Mohler and Smith 1986):

- Provide training and education to manufacturers and ciealers on the purpose, benefits, and responsibilities of participation in the Super Good Cents program.

- Allow manufacturers maximum flexibility in meeting the Super Good Cents standards.
- Allow manufacturers to self-certify their manufactured homes as meeting the Super Good Cents standards.

- Provide manufacturers and dealers with detailed market information to help reduce risks associated with the construction and inventorying of Super Good Cents homes.

- Implement advertising and promotional strategies with participants on a cooperative or allowance basis.

- Provide dealers with a rebate or purchase allowance to reduce the costs associated with carrying inventories of Super Good Cents units.

- Offer consumers rebates or other financial incentives to purchase Super Good Cents manufactured homes.

- Encourage lending institutions to stretch normal debt-to-income ratios for consumers purchasing Super Good Cents manufactured homes.

- Encourage insurance companies to reduce the premiums on Super Good Cents units.

$* * * * *$

The manufactured homes project was now firmly focused on new construction and the original technical staff was now working in program development to bring the concept into reality. On every front, from thermal performance to logo design, Bonneville managers had begun to develop solid data and firmer plans. The "mix" was beginning to gel.

\section{End Notes}

1 Letter on the energy-efficient manufactured housing test and marketing program from the Director, Division of Residential Programs, to the Manufactured Housing Project Mailing List. February 11, 1985.

Bonneville Power Administration, Portland, Oregon.

2 Interoffice memorandum on the mobile home revisions to the long-term residential sector 
forecast from the Chief, Residential and Commercial Energy Analysis Section (PNED), and the Chief, Economic Studies Section (PNID), to the Chief, Conservation Planning Branch (KEP). June 17, 1985. Bonneville Power Administration, Portland, Oregon.

3 Interoffice memorandum defining manufactured housing from the Manufactured Housing Program Manager (KRP) to the Director, Division of Residential Programs (KR), via the Chief, Consumer Products and Services Branch (KRP). June 24, 1985. Bonneville Power Administration, Portland, Oregon.

4 Interoffice memorandum reviewing the marketing energy conservation options for Northwest manufactured home buyers from the Public Utilities Specialists, Conservation Planning Branch (KEP), to the Manufactured Housing Program Manager, Consumer Products and Services Branch KRP). August 7, 1985. Bonneville Power Administration, Portland, Oregon.

5 Letter on the task order to develop a strategic plan from the Manufactured Housing Program Manager, Consumer Products and Services Branch (KRP), to Wagner, Wiecks, Smith and Lapel, Portland, Oregon. August 16, 1985. Bonneville Power Administration, Portland, Oregon.
6 Interoffice memorandum on the game plan for manufactured housing (response to July 19 note) from the Chief, Consumer Products and Services Branch (KRP), to the Assistant Administrator for Conservation (K) via the Director, Division of Residential Programs (KR). August 1, 1985. Bonneville Power Administration, Portland, Oregon.

7 Interoffice memorandum on the impact of the 1985 draft council plan on the BPA energy efficient manufactured housing program from the Manufactured Housing Program Manager (KRP) to the Acting Chief, Consumer Products and Services Branch (KRP). September 17, 1985. Bonneville Power Administration, Portland, Oregon.

8 Letter on the plans to include manufactured homes in Super Good Cents from the Manufactured Housing Program Manager, Consumer Products and Services Branch (KRP) to Shearer and Carr Associates, Pơrtland, Oregon. September 25, 1985. Bonneville Power Administration, Portland, Oregon.

9 Letter from Frank Walter, Vice President, Technical Activities to Jean Boulin, Office of Building Energy Research and Development, DOE, Washington, D.C. September 6, 1985. Manufactured Housing Institute, 1745 Jefferson Davis Highway, Arlington, Virginia. 


\section{CHAPTER 7: REACHING FOR CONCLUSIONS -- And for Consensus}

As 1986 began, Bonneville was reaching out -- and in a different way. Bonneville was reaching out not only to familiar customers and cohorts in the utility industry but to a more vast, more diversified, audience. Bonneville was, after all, hard-wired to everyone in the region through the Northwest power grid, but the degree of involvement - the outreach - that began in the mid-1980s would have been unthinkable prior to the passage of the Pacific Northwest Electric Power Planning and Conservation Act.

The region's increasing dialogue and involvement in power issues was a new phenomenon. The Council's first 20-year power plan had emphasized that regional power issues would be treated publicly, that decisions would be made in an open process. Now, in the new 1986 Northwest Conservation and Electric Power Plan (the Power Plan), the Council extended this concept to provide for public involvement in every aspect of Bonneville's activities. It called for Bonneville to develop detailed work plans to achieve the objectives outlined in the 1986 Power Plan and to develop these through a public process (NWPPC 1986).

\section{Outreach and Consensus}

While this affected the manufactured housing project generally, in conservation matters increased outreach was already a natural consequence of Bonneville actions. Efforts across the board - commercial, industrial, residential -- revealed there were many key factors involved in any conservation venture -code officials, conservation advocacy groups, state energy offices (SEOs), the Council's technical team. The experience of the 1970s and early 1980s had already convinced Bonneville that energy savings could not be achieved in a vacuum:
- Weatherization experience had led Bonneville into liaison with regional contractors, the building products industry, code officials, SEOs, and other interested parties including home owners.

- Its recently completed Residential Standards Demonstration Project, which consisted of building over 400 homes to the MCS to train builders, code officials, and others to the first-hand realities - and benefits -- of the new standards, brought Bonneville into "hands-on" relationships with a new regional constituency.

- As Bonneville designed and introduced the Super Good Cents program, it had learned, from pragmatic experience, the importance and practical value of developing a broadbased consensus, a shared understanding among would-be participants before a new program is designed and launched.

\section{FORGING NEW TOOLS}

Along with several new projects, the 1986 Power Plan called on Bonneville to extend the Residential Standards Demonstration Project into an "ongoing research and demonstration effort," focused initially on the residential sector. The new program - the Residential Construction Demonstration Project - would ultimately play a key role in the evolution of the manufactured housing project.

\section{Fostering a Forum}

For the developing manufactured housing project, therefore, the Council's increased emphasis on outreach and consensus was not a new direction; it simply underscored what was already understood and confirmed, the direction that was already being taken. The project manager had learned first-hand in the Technical Support Branch that outreach was essential. Each new research study suggested this could be even more the case with manufactured 
housing. As Bonneville and PNL were continuing to discover, this industry had its own "rules," its own "hot buttons," its own movers and shakers. As the project matured throughout 1986, the Bonneville project team dutifully took advantage of any opportunities to learn more about how the industry worked and to establish contact with as many of its potential new partners as possible.

One of the characteristics of the project from the beginning was the way in which day-to-day experience was used as an opportunity to share information, to build a network of individuals and organizations involved and interested in manufactured housing and/or energy efficiency. Because the manufactured housing project was now managed within the Consumer Products and Services Branch, the environment was marketing-oriented and consumer-directed; this environment encouraged the continuation of this networking approach. One of the major activities of the branch, for example, was the development of the Super Good Cents program, an undertaking in which communication and cooperation were critical factors.

\section{Learning from Test Home Construction}

The reluctance of the manufacturers to bid on constructing Bonneville's test homes was not only a discouraging index of their reaction to the goals the program hoped to accomplish. It also indicated the industry's resistance to the introduction of new, untested designs and techniques into the manufacturing process. Once TLP contracted to redesign the test homes and assumed responsibility for their construction by Glen River Industries, Glen River Industries plant experience was able to provide valuable insight into possible solutions for the industry's indifference.

Early in 1986, the Bonneville project manager and the branch manager visited the Glen River Industries plant to see first-hand what was involved. As they saw the speed at which "floors" moved through the plant (the industry refers to home sections being assembled as "floors"), they began to appreciate the industry's need for clear-cut, consistent specifications -- to better understand why manufacturers had thus far been so disinclined to alter their manufacturing process. Home assembly was a finely tuned operation, and profit and loss depended on keeping the line running without costly delays. "For want of a nail..." starts an old story whose moral is that the smallest problem could result in a costly delay. The need to spell out specifications in clear and no uncertain terms was a lesson made obvious to Bonneville once inside a busy plant.

But other important lessons were also learned from the visit to Glen River Industries: specifications could be tailored to plant operations and to the specilic design of the home being upgraded and that workers could be trained to the new specifications. These discoveries could go a long way toward lowering the barriers between Bonneville and the industry.

\section{The Role of the DAPIA}

Bonneville was exploring other ways of smoothing out the process. In 1986, besides the five-home demonstration project, a number of smaller studies were also undertaken to gain a closer look at some of the key factors playing a role in manufactured housing designs. The purpose of these studies was to better understand the different roles and responsibilities of various participants within the manufacturing process. By doing so, Bonneville hoped to be in a better position to plan its program so that it complemented standard industry practice instead of potentially creating problems and disruptions.

One such study, "The Role of the DAPIA in the Manufactured Housing Process" was conducted by PNL and completed in March 1986 (Balistocky et al. 1986). It found that all design approvals for plants located in the Pacific Northwest were performed by any one or a combination of five DAPIAs -- two in California, one in Chicago, one in Florida, and 


\section{WHAT'S A DAPIA?}

The Code of Federal Regulations (CFR) spells out the requirements that must be met by the industry to ensure that new manufactured homes are designed and constructed to meet the HUD code. These include specific requirements that govern (1) design approval, (2) design certification, and (3) unit inspection. To carry out these responsibilities, a number of agencies were created:

- The Design Approval Primary Inspection Agencies (DAPIAs) carry out the design approval and certification.

- The Inspection Primary Inspection Agencies (IPIAs) are responsible for inspecting units produced to ensure they are built to the approved design.

- State Administrative Agencics (SAAs) may be contracted to play a role in these processes and deal with consumer complaints about quality.

- The work of the DAPIAs is monitored by an outside agency under a HUD contract that must be competed and renewed every 3 years. Currently, this contractor is the National Conference of States on Building Codes and Standards (NCSBCS).

one in Texas. Typical fees for DAPIA services ranged from $\$ 100$ to $\$ 250$ for a design modification and $\$ 700$ to $\$ 1,200$ for a totally new design. Manufacturers were free to choose the DAPIA(s) they wished to employ and based their decisions on the range and quality of services needed or provided.

The DAPIA representatives contacted for the study did not believe that the Federal Manufactured Housing Construction and Safety Standard -- the HUD code -- was an impediment to achieving the MCS levels of energy efficiency. In their view, the impediments were far more likely to be lack of consumer enthusiasm and the increased manufacturing costs arising from any plant disruptions and the inefficiency that production of alternate models could create. They emphasized that lack of consumer support was the most significant barrier to improved energy efficiency in manufactured housing. DAPIA representatives stressed that in their view there was no design, process, or regulatory barrier to achieving greater energy efficiency in most manufactured home designs produced in the Northwest at that time (Balistocky et al. 1986).

The DAPIAs contacted varied in their assessment of the role they might play in assisting Pacific Northwest manufacturers to achieve MCS levels of energy efficiency. Their responses ranged from "none" to "significant." If called upon by Bonneville to ensure that an MCS design was in compliance with HUD standards, DAPIAs could do so based on their current responsibilities. On the other hand, if asked to certify compliance with the MCS, the respondents stressed they would have to become familiar with the criteria and specifications they were being asked to review. Each DAPIA contacted expressed appreciation for being kept informed about potential industry developments -- another vote from another quarter for consensus building!

\section{Preliminary Thermal Performance Data}

The big-time event in March 1986, was the siting of the five demonstration homes in Vancouver and Richland. With the heating season nearly over, the pressure for immediate monitoring was intense and PNL installed Field Data Acquisition Systems (FDASs), which were part of the ELCAP monitoring system discussed in Chapter 5. The houses were to be monitored even though unoccupied. As important as energy performance was, however, indoor air quality was equally critical. At this point in time there was considerable uncertainty about the effect of increased insulation and "housetightening" on indoor air quality (Lee et al. 1986).

Infiltration was another issue -- a factor in both indoor air quality and thermal performance -- and one of the first tests was conducted almost immediately to determine the effect of transporting a manufactured home on its thermal integrity. Blower door and air exchange rate measurements indicated that leakage areas and air exchange rates increased 
significantly (from about $20 \%$ to $100 \%$ ) after the test homes were transported. Despite these significant percentage increases, however, the homes still had relatively low air exchange rates after transport (less than about $0.2 \mathrm{ACH}$ ) (Lee et al. 1986).

In the meantime, infiltration testing was also being conducted by Bonneville's Division of Laboratories on the 34 manufactured homes sited on the Tulalip Indian Reservation.

According to a Bonneville report, completed in April 1986 (Ek 1986): "Tests showed the manufactured housing on the Tulalip Indian Reservation to have leakage rates significantly lower than anticipated. Test results predict natural air exchange rates for the twenty homes from 0.26 to 0.37 air changes per hour (ACH)."

\section{Preliminary Cost Analysis}

In June 1986, the Bonneville project group had collected sufficient data on the cost of upgrading HUD code manufactured homes to the site-built homes MCS to issue a report, "The Cost of Energy Efficiency in HUD code Manufactured Homes" (Onisko 1986). The report was based on PNL's analysis of the five demonstration homes and Bonneville's experience with the 34 homes built for the Tulalip Indian $\mathrm{g}^{2}$ eservation. These costs were by no means fixed or definitive, but at this early stage they helped to gauge in a general way whether the upgrades were at all feasible in terms of cost effectiveness. Preliminary indications showed that they were.

Table 7.1 summarizes the upgrade cost and estimated energy savings for the five demonstration homes and indicates total projected energy savings and estimated customer costs. The material cost increases known at this point were multiplied by a value that represented the estimated additional markup costs (transport, overhead, labor, etc.) that were incurred in the upgrade and would be passed on as part of the total cost.
Table 7.2 summarizes the upgrade cost for the 34 Tulalip homes. This case differed from the five-home demonstration situation in several respects: (a) the homes were produced by a different supplier, (b) nearly seven times more homes were built under the contract, (c) all homes were small double-wides, (d) the homes were built to climate zone $1 \mathrm{MCS}$ requirements only, and (e) the manufacturer "passed through" the cost based on material costs only. In this case, the added price of any option is passed on to the dealer at material invoice price with the understanding that the dealer will pass this cost on to the consumer "at cost." Not all dealers are willing to do this and not all options can be handled in this manner. To make the Tulalip upgrade costs comparable to those for the demonstration homes, Bonneville applied a markup factor of 2.22. (This figure, obtained from HUD and based on several of their studies, was cited by PNL in a report prepared for the DOE [Balistocky et al. 1985] that was available to Bonneville at the time of the cost analysis.)

\section{Developing HUD/MCS Comparisons}

To go beyond mere cost reporting and make a preliminary assessment of the costeffectiveness of the potential energy-savings, the preliminary cost analysis report detailed a means of comparing the HUD code and the MCS requirements (Onisko 1986). While both the MCS and the Federal Manufactured Housing Construction and Safety Standard prescribe a method to calculate the energy requirements of a home based on its envelope construction, the methodologies differ. HUD uses a $U_{0}$ based on the entire envelope. The MCS methodology is based on energy usage per square foot of gross floor area and is also called a thermal performance criteria. The HUD standard does not include heat losses due to infiltration while the MCS calculation takes these losses into account. 
TABLE 7.1 - Comparison of Computer Model Estimated Annual Energy Budgets and Customer Cost of MCS Compliance (five demonstration homes)

\begin{tabular}{|c|c|c|c|c|c|c|}
\hline & $\begin{array}{l}\text { Floor } \\
\text { Area In } \\
\text { sq.ft. }\end{array}$ & $\begin{array}{l}\text { Estimated } \\
\text { HUD } \\
\text { Energy } \\
\text { Budget In } \\
\text { kWh/sq.ft. }\end{array}$ & $\begin{array}{l}\text { Estimated } \\
\text { MCS } \\
\text { Energy } \\
\text { Budget in } \\
\text { kWh/sq.ft. }\end{array}$ & $\begin{array}{l}\text { Estimated } \\
\text { Energy } \\
\text { Savings In } \\
\text { kWh/sq.ft. }\end{array}$ & $\begin{array}{l}\text { Estimated } \\
\text { Customer } \\
\text { Cost* In } \\
\text { Dollars }\end{array}$ & $\begin{array}{l}\text { Estimated } \\
\text { Customer } \\
\text { Cost* In } \\
\$ / \text { sq.ft. }\end{array}$ \\
\hline $\begin{array}{l}\text { Climate Zone } 1 \\
\text { Model } 101 \text { (SW) } \\
\text { Model } 211 \text { (DW) } \\
\text { Model } 312 \text { (DW) }\end{array}$ & $\begin{array}{r}924 \\
1,740 \\
1,350\end{array}$ & $\begin{array}{l}5.56 \\
5.97 \\
5.45\end{array}$ & $\begin{array}{l}1.92 \\
1.79 \\
1.90\end{array}$ & $\begin{array}{l}3.64 \\
4.18 \\
3.55\end{array}$ & $\begin{array}{r}\$ 4,471.02 \\
8,106.66 \\
6,471.63\end{array}$ & $\begin{array}{c}\$ 4.84 \\
4.66 \\
4.79 \\
\text { Avg }=\$ 4.76\end{array}$ \\
\hline $\begin{array}{l}\text { Climate Zone } 2 \\
\text { Model } 302 \text { (DW) }\end{array}$ & 1,512 & 9.08 & 3.15 & 5.93 & $\$ 8,040.19$ & $\$ 5.32$ \\
\hline $\begin{array}{l}\text { Climate Zone } 3 \\
\text { Model } 203 \text { (DW) }\end{array}$ & 1,305 & 10.28 & 3.13 & 7.15 & $\$ 8,705.51$ & $\$ 6.67$ \\
\hline \multicolumn{7}{|c|}{$\begin{array}{ll}\mathrm{SW}= & \text { Single-wide } \\
\mathrm{DW}= & \text { Double-wide } \\
* & \text { Customer cost is equal to } 2.4 \times \text { material cost. Markup includes transport, administrative } \\
& \text { overhead, insurance, labor, advertising, and profit. Cost includes volume discount. } \\
\text { Source: } & \text { Onisko } 1986\end{array}$} \\
\hline
\end{tabular}

TABLE 7.2 - Option Markup of Tulalip Homes (Climate Zone 1)

\begin{tabular}{||l|c|c|c|c|}
\hline $\begin{array}{c}\text { Description of } \\
\text { Home }\end{array}$ & Floor Area (in sq.ft.) & $\begin{array}{c}\text { Cost of MCS } \\
\text { Upgrade (dollars) }\end{array}$ & $\begin{array}{c}\text { Estimated Retail } \\
\text { Cost }\end{array}$ & $\begin{array}{c}\text { Customer Cost in } \\
\$ / s q . f t .\end{array}$ \\
\hline 2 Bedroom & 850 & $\$ 1,655.00$ & $\$ 3,674.00$ & $\$ 4.32$ \\
\hline 3 Bedroom & 1,050 & $\$ 1,795.00$ & $\$ 3,985.00$ & $\$ 3.80$ \\
\hline 4 Bedroom & 1,190 & $\$ 1,973.00$ & $\$ 4,380.00$ & $\begin{array}{c}\$ 3.68 \\
\text { (Avg. }=\$ 3.93 \text { ) }\end{array}$ \\
\hline \hline Source: Onisko 1986
\end{tabular}

The MCS annual energy use can be converted to a Heat Loss Budget, expressed in $\mathrm{Btu} / \mathrm{hr}\left({ }^{\circ} \mathrm{F}\right)$ (sq.ft.) but the units of area are different. The square footage in the MCS calculation represents heated floor space while the area in the HUD calculation represents the combined area of the home's walls, ceiling, and floors. To compare equivalent areas, a model home is required. For this purpose, a fairly typical $28 \mathrm{ft}$. $\times 48 \mathrm{ft}$. $\times 7.5 \mathrm{ft}$. manufactured home approximating the dimensions of the 1,350-sq.ft. home used by the Council as a sitebuilt prototype can be utilized. The typical manufactured home used for comparison would have 1,344-sq.ft. floor and ceiling areas and $1,140 \mathrm{sq}$.ft. of wall/window/door area. 
The report provided a useful and informative step-by-step analysis of how the MCS standard was converted to thermal transmittance expressed in Btu/hr ( $\left.{ }^{\circ} \mathrm{F}\right)$ (sq.ft.) by component (walls/ceilings/floors) for each of the region's three MCS climate zones. This permits an analyst to calculate an estimated $U_{0}$ based on the MCS, as shown in Table 7.3.

TABLE 7.3 - MCS Thermal Performance Expressed as Heat Loss

\begin{tabular}{|c|c|}
\hline Climate Zone & $\mathrm{U}_{\mathrm{o}} \mathrm{Btu} / \mathrm{hr}\left({ }^{\circ} \mathrm{F}\right)$ (sq.ft.) \\
\hline 1 & 0.059 \\
\hline 2 & 0.047 \\
\hline 3 & 0.046 \\
\hline
\end{tabular}

These values continue to differ from the values represented by the HUD standard because they include allowances for infiltration heat loss while the HUD standard does not. This, of course, was at the core of Bonneville's desire to comprehensively measure the actual infiltration rates in manufactured homes. Nevertheless, based on limited experience with the solar energy home, the test homes, and preliminary infiltration measurements obtained in the Tulalip homes, Bonneville was reasonably confident that infiltration rates of approximately $0.35 \mathrm{ACH}$ on average could be applied. When this was done, the HUD standard $\left(U_{0}\right)$ could be adjusted and expressed for each of the three climate zones (with differences due to the varying influence of climate conditions on the heat loss effects of infiltration) as shown in Table 7.4.

Now the energy usage of homes built to the HUD standard could be calculated and compared to the energy usage of similar homes built to the MCS to obtain comparable estimates of energy savings. When these, in turn, were multiplied by levelized electricity costs expressed in cents/kWh, an estimate of the
TABLE 7.4 - MCS Thermal Performance Expressed as Heat Loss

\begin{tabular}{|c|c|}
\hline Climate Zone & $\mathrm{U}_{\mathrm{o}}$ Btu/hr $\left({ }^{\circ} \mathrm{F}\right)(\mathrm{sq} . \mathrm{ft})$. \\
\hline 1 & 0.143 \\
\hline 2 & 0.141 \\
\hline 3 & 0.141 \\
\hline
\end{tabular}

upper reaches of regional cost effectiveness was developed as shown in Table 7.5.

\section{Developing Marketing Sensitivity}

The discussion of these early cost calculations, while complex, is far clearer and convincing in retrospect than during these early forays into gauging cost effectiveness based on limited information. The point is that Bonneville took advantage of its cost experience as soon as possible to assess the reality of proceeding with the project and to gain insight into the marketing challenges that the increased costs imposed. This early cost review concluded by citing strongly held industry views that the market was consumer driven and Bonneville acknowledged that many manufactured home customers may, indeed, be very price sensitive. The report also noted that keen competition in the industry was a factor that had to be considered (Onisko 1986).

The tendency, the report noted, was for the industry to be conservative, to avoid losing a customer by "trying to sound like we are pushing something they really can't afford." What the extensive preliminary cost analysis had shown, however, was that the upgrades appeared to be extremely cost-effective for the region. For the moment, Bonneville was willing to accept the industry's view that the price was too high for customers to bear. That being the case, the preliminary cost analysis concluded prophetically (Onisko 1986): 
TABLE 7.5 - A Comparison Of Maximum Allowable Incremental Cost to Actual Project Cost at 4.5 Cents/kWh

\begin{tabular}{|c|c|c|c|c|c|c|}
\hline \multirow[b]{2}{*}{ Model } & \multicolumn{2}{|c|}{$\begin{array}{l}\text { Allowable Costs } \\
\text { (at } 4.5 \mathrm{c} / \mathrm{kWh} \text { ) }\end{array}$} & \multicolumn{4}{|c|}{$\begin{array}{c}\text { Actual Costs } \\
\text { (based on Demonstration and Tulalip homes) }\end{array}$} \\
\hline & $\begin{array}{c}\text { Allowable } \\
\text { Costs } \\
\$ / \text { sq.ft. }\end{array}$ & $\begin{array}{l}\text { Allowable } \\
\text { Cost In } \\
\text { Dollars }\end{array}$ & $\begin{array}{l}\text { Actual } \\
\text { Costs } \\
\text { \$/sq.ft. }\end{array}$ & $\begin{array}{l}\text { Actual } \\
\text { Material } \\
\text { Costs }\end{array}$ & $\begin{array}{l}\text { Retail } \\
\text { Cost } \\
\text { \$/sq.ft. }\end{array}$ & $\begin{array}{l}\text { Customer } \\
\text { Cost } \\
\text { In Dollars }\end{array}$ \\
\hline $\begin{array}{l}\text { Climate Zone } 1 \\
\text { Tulalip } \\
2 \text { Bedroom } \\
3 \text { Bedroom } \\
4 \text { Bedroom } \\
\text { Demonstration } \\
\text { Model } 101 \\
\text { Model } 211 \\
\text { Model } 312\end{array}$ & $\begin{array}{r}\$ 2.27 \\
2.27 \\
2.27 \\
\\
\\
2.27 \\
2.27 \\
2.27\end{array}$ & $\begin{array}{r}\$ 1,929.50 \\
2,383.50 \\
2,701.30 \\
\\
2,079.48 \\
3,949.80 \\
3,064.50\end{array}$ & $\begin{array}{r}\$ 1.95 \\
1.71 \\
1.72 \\
\\
1.91 \\
1.36 \\
1.50\end{array}$ & $\begin{array}{l}\$, 655.00 \\
1,795.00 \\
2,046.00 \\
\\
1,746.31 \\
2,363.22 \\
2,020.91\end{array}$ & $\begin{array}{r}\$ 4.33 \\
3.80 \\
3.82 \\
\\
\\
\\
4.33 \\
3.01 \\
3.32\end{array}$ & $\begin{array}{r}\$ 3,674.00^{*} \\
3,985.00^{*} \\
4,542.00^{*} \\
3,916.77+ \\
5,246.35+ \\
4,486.42+\end{array}$ \\
\hline $\begin{array}{c}\text { Climate Zone } 2 \\
\text { Demonstration } \\
\text { Model } 302\end{array}$ & 5.19 & $7,847.28$ & 1.54 & $2,328.32$ & 3.42 & $5,168.88+$ \\
\hline $\begin{array}{c}\text { Climate Zone } 3 \\
\text { Demonstration } \\
\text { Model } 203\end{array}$ & 5.44 & $7,099.20$ & 1.79 & $2,339.11$ & 3.98 & $5,192.82+$ \\
\hline
\end{tabular}

The choice seems clear. A cash incentive paid directly to the manufacturer would benefit the region.

\section{Building a Constituency}

All of the developments during the early part of 1986 were broadly circulated and the "mailing list" for the manufactured housing project grew larger and larger. Throughout thefirst half of 1986, the branch manager and the manufactured housing project manager discussed the formation of a Manufactured Housing Work Group. This process had been used in setting up the Super Good Cents program and the branch manager had become a strong advocate of "consensus building." This approach, of course, was exactly in line with the increased emphasis on public participation stressed in the Council's 1986 Power Plan.

About mid-year, plans had gelled sufficiently for the branch manager to initiate a formal recommendation to Bonneville management. It proposed that the Agency: ${ }^{1}$

\section{Establish an Energy-Efficient} Manufactured Housing Work Group which consists of members which are representative of the concerns and interests of the industry. Each member is representative of a specific element of the industry. The suggested 
categories of membership and recommended participants are as follows: (The names of specific participants have been omitted in accordance with the general approach of this report which has been to chronicle events and actions of organizations but not individuals.)

\section{State Manufactured Housing Associations (MHAs) \\ - WMHA (Washington) \\ - OMHA (Oregon) \\ - IMHA (Idaho) \\ - MMHA (Montana)}

\section{Regional Manufacturers}

3. State Inspection Agencies (IPIAs)

- Oregon

- Washington

- Idaho

4. Manufactured Home Owner Associations

- Washington

- Oregon

5. BPA Customer Utilities

- Two from each Area nominated by Regional Operations

6. Regional Power Councils/Associations/ Authorities

- Northwest Power Planning Council

- Pacific Northwest Utilities Conference Committee

- Pl:olic Power Council

7. Bonneville Power Administration

- Director, Division of Residential Programs

- Chief, Consumer Products and Services Branch

- Chief, Conservation Planning Branch

- Evaluation and Planning Branch Program Manager

- Regional Operations Representative

- Manufactured Housing Program Manager

\section{Suppliers}

9. Dealers.

The recommendation was approved, and in late summer the invitations went out. They were hardly gilt-edged -- participants had to pay their own expenses - but the response was encouraging. The first meeting was called for November 17, 1986 and the agenda was set for two major activities. ${ }^{2}$

The first, beginning the meeting, was an outline of the background, including a short overview of the roles of Bonneville, the Council, and the industry. Then Bonneville outlined its present plan, describing the Tulalip Reservation homes and the five Demonstration homes. This review included its plans for training, a discussion of blower door testing, methods used for forecasting housing starts, and data collection and field survey plans.

Bonneville then outlined its present work plan in detail, detailing the objectives of its effort, the major activities scheduled, and the role and organization of the Work Group itself. At this point, Bonneville underscored the importance of cooperation among all the parties involved in the undertaking. The schedule for the project at this point is shown in Table $7.6 .^{2}$

In the meantime, a program to promote the most energy efficient homes at a level no higher than that already demonstrated or possible in the industry would be formulated for public review. Working closely with the industry, this program would be completed by the end of fiscal year (FY) 1987 or early in FY 1988. This program would be implemented in FY 1988 and continued through 1991.

At this point plans called for the Work Group to break into four smaller discussion groups to answer these questions: ${ }^{2}$

- Is the Work Plan consistent with BPA's efforts to promote energy efficiency in the manufactured housing consumer sector 
TABLE 7.6 - Project Schedule

\begin{tabular}{||l|c||}
\hline $\begin{array}{l}\text { Draft report on regional } \\
\text { cost-effective level of } \\
\text { energy efficiency for HUD } \\
\text { code homes }\end{array}$ & $9 / 87-10 / 87$ \\
\hline $\begin{array}{l}\text { Design and implement } \\
\text { pilot project to acquire } \\
\text { additional data on cost- } \\
\text { effectiveness }\end{array}$ & $10 / 87-3 / 88$ \\
\hline $\begin{array}{l}\text { Monitor completed homes } \\
\text { and analyze results }\end{array}$ & $1988-1990$ \\
\hline $\begin{array}{l}\text { Establish regional cost- } \\
\text { effective level for } \\
\text { Regionwide Acquisition } \\
\text { Program }\end{array}$ & $19 / 90$ \\
\hline $\begin{array}{l}\text { Regionwide Acquisition } \\
\text { Program Design and } \\
\text { implement program }\end{array}$ & $1991-1992$ \\
\hline
\end{tabular}

and is it acceptable [to] the industry or to your particular interests?

- From your point of view does the Work Plan adequately cover all the important issues needed to build and sell energyefficient housing?

- From your point of view is the Work Plan realistic, sensible, and achievable?

- What changes would you make in the Work Plan that will improve it? What changes would you recommend?

\section{A Robust Response}

In general, most groups thought the plan was consistent with Bonneville's efforts and was acceptable. ${ }^{3}$ However, there was almost universal agreement that more needed to be done. For example, not enough was known about current practices. What would the improved energy-efficient homes be compared to? The price-sensitivity of the market was stressed and many participants questioned the feasibility of any approach that did not feature incentives. But if questions and caution were the hallmarks of the first meeting, so too were a definite spirit of cooperation, a willingness to "wait and see," and some breaking down of the barriers between "us" and "them" -- on what were, in fact, several sides of the table.

\section{WORK GROUP TASKS}

The work group would be asked to perform the following tasks:

1. Provide information to Bonneville for use in the design and implementation of a regional demonstration and marketing program in the manufactured housing sector. Provide a free exchange of information between all regions and all participants of the Working Group.

2. Review proposed programs, procedures for established programs, and proposals for changes in those programs or procedures. Make recommendations to Bonneville's program manager.

3. Review any program specifications, and proposals for changes in (or interpretations of) those specifications.

4. Review program results. Provide consistency and fairness in the delivery of the market program.

5. Meet at least two times per year to provide a forum for all matters of substance, opinion, and interest related to the region, industry, and Bonneville. These meetings will promote the exchange of information and results, offer a forum for any changes in program direction, specifications, or procedures, and permit discussion of proposed program innovations.

The question concerning additional recommendations provided a wealth of new and thought-provoking ideas: ${ }^{3}$.

- Defer the promotional program or pilot project until cost-effectiveness research is completed.

- Locate 200 pilot homes in the region.

- Address low-end of market. 
- Address transport and set-up problems.

- Disseminate experience and knowledge throughout industry.

- Use inspectors/certifiers for quality control.

- Avoid conflicts between utilities, manufacturers, and dealers.

- Market to consumers.

- Determine individual measure costs.

- Establish database for the energy efficiency of current-practice manufactured homes to include cost, performance (monitor minimum 1 year), and energy features -extend time line to establish database.

- Address equity issues -- manufactured housing efforts apply to new housing and need to include retrofit. Incentives are offered for site-built homes and none for manufactured housing.

\section{End Notes}

1 Interoffice memorandum on the suggested energy-efficient manufactured housing work group from the Chief, Consumer Products and Services Branch (KRP), to the Director, Division of Residential Programs (KR). August 20, 1986. Bonneville Power Administration. Portland, Oregon.

2 Letter on the suggested work group including (a) proposed agenda, (b) BPA's proposed work plan and (c) small group discussion issues from the Director, Division of Residential Programs (KR), to the
- Need more than a promotion effort targeting specific energy-efficient models. Perhaps a general education/consumer program designed to increase energy awareness about manufactured housing is needed.

- Include all trade and supplier allies.

What a year! Progress toward developing real-world experience and test data was matched by progress toward establishing a dedicated group of people genuinely interested and committed to advancing the project. The biggest hurdle was time -- there just wasn't enough time, it seemed. Very shortly, other shortages would hamper progress even more. Another facet, another hurdle, another chapter.

Prospective Manufactured Housing Work Group Members. October 3, 1986. Bonneville Power Administration, Portland, Oregon.

3 Letter on feedback concerning the November 17, 1986, meeting, including specific discussion group comments from the Chairman, Manufactured Housing Work Group [Chief, Consumer Products and Services Branch (KRP)], to the Work Group Members. December 18, 1986. Bonneville Power Administration, Portland, Oregon. 


\section{CHAPTER 8: COUNTDOWN TO CLOSURE -- Building to a Regional Test}

Even while enthusiasm was being kindled, cooperation being warmed to life, and imaginations set afire in the first Manufactured Housing Work Group meeting, Bonneville was taking steps to initiate massive budget cutbacks in 1987. Triggered by a marked loss of revenue (see Box - BPA's Revenue Crunch), the cutbacks were no doubt painful for many of the offices of the agency -- Engineering, Regional Operations, Power Sales. For Conservation, however, they were nearly fatal. The most severe cuts were scheduled in areas where Bonneville believed it had the most flexibility -- conservation, fish and wildlife, and system planning and construction (NWPPC 1986).

Conservation outlays had grown to $5.7 \%$ of Bonneville's total obligations, a larger share of discretionary spending than the percentage figure suggests. Most of Bonneville's expenses simply could not be trimmed -- payments on Washington Public Power Supply System (WPPSS) obligations, payments to utilities to cover the cost of power exchanges, payments for interest and repayment of federal obligations. WPPSS guarantees were the biggest factor; these inflexible obligations accounted for $40 \%$ of Bonneville's budget at the time (NWPPC 1986).

Although conservation outlays were flexible compared to other areas of the budget, the cuts were far from painless; they placed the Conservation staff under more stress and future planning in more jeopardy than might have been anticipated. The cooperation that had been found to be essential to making the conservation resource real and reliable, so slowly and carefully fostered, was tenuous at best; individuals and industries not familiar with Bonneville simply could not understand how the agency could blow so "hot" one minute and so "cold" the next.

\section{BPA'S REVENUE CRUNCH}

The FY 1987 cutbacks were triggered by sharp declines in both of BPA's major sources of revenue - its export sales to Califormia and its direct sales to the region's aluminum producers. World-wide commodity price declines affected both in a drastic manner.

World oil prices had sharply declined in 1986, making California's oil-fired generation plants highly competitive with Northwest hydropower. To avoid losing sales volume, BPA was forced to lower its wholesale rates -keeping the customer but losing the revenue.

The world aluminum market was also depressed, flooded with the output of highly subsidized operations in developing nations. Regional aluminum producers were hard pressed; and they accounted for most of Bonneville's direct sales to major industrial customers what BPA calls the Direct Service Industries. To shore up the flagging industry, BPA had instituted a variable rate that had now declined sharply, reflecting the plummeting 1987 prices. Keeping the customer but losing the revenue.

By this time, however, some sort of "critical mass" had evidently been reached in the manufactured housing project. The ideas presented to the first Manufactured Housing Work Group in the fall of 1986 and the "wish list" that had been developed were strong and appealing enough to weather nearly a year and a half of backing and filling while Bonneville firmed up its finances, its analysis, and its planning.

\section{Gauging Current Practice}

At Bonneville, the work on the project continued and maximum use was made of the resources that were available, such as staff time. An important analysis of one facet of the project began almost before the Work Group meeting was over. One of the strongest and most universally expressed ideas at the Work 


\section{MANUFACTURERS SURVEYED}

$\begin{array}{ll}\text { Champion } & \text { Moduline } \\ \text { Fleetwood } & \text { Silvercrest } \\ \text { Guerdon } & \text { Skyline } \\ \text { KIT } & \text { Zimmer } \\ \text { Libesty } & \end{array}$

Group meeting was that Bonneville needed to develop a better understariding of "current practice." While the HUD code required that all manufactured homes meet a minimum thermal requirement, the consensus of the manufacturers was that most new manufactured homes produced in the Pacific Northwest exceeded this level of energy efficiency. The incremental improvement being sought, therefore, was undoubtedly less than a comparison of the Federal Manufactured Hor sing Construction and Safety Standard and $\mathrm{MC}$ is requirements might indicate. The burning question was: How much less? Or, conversely: What is the real magnitude of the energy savings the region can achieve by building manufactured homes to the MCS compared to what's being built now?

By early Jani'ary 1987, the Bonneville project manager had addressed this question and issued a report that examined the current practice of Pacific Northwest manufacturers (BPA 1987a). The survey covered nine manufacturers representing about $90 \%$ of the region's production and sales of single-wide and double-wide homes. A total of 12 plants in Oregon, Washington, and Idaho were involved; there were no plants in Montana. At each plant, the plant manager, plant engineer, or quality control supervisor was asked to describe energy-efficient measures installed in their standard product, their most popular product, and their best available (and possibly rnost energy-efficient) product. In addition, the respondents were asked to provide information regarding:

- average floor size
- overall glazing area

- use of any exotic products or materials.

Using the SUNDAY 87 computer program, simulated energy usage was calculated and analyzed for three locations - Seattle, Spokane, and Missoula -- representing the three climate zones into which the region was divided by the MCS. Single-wide and double-wide homes were analyzed separately because the singlewides generally were slightly more energy efficient for equal insulation levels. It was assumed that this was partly because they had less heated floor space than double-wides and partly because SUNDAY used a constant internal heat gain (from lighting, appliances, and occupants) of $3,000 \mathrm{Btu} / \mathrm{hr}$.

Only 7 of the 12 plants produced enough single-wides to consider in the aralysis but these provided a fair representation. Their sizes varied from 770 to 924 sq.ft. and the average floor area was calculated to be 844 sq.ft. It was found that on average the best available single-wide models could marginally meet MCS requirements in the Seattle area (climate zone 1) but this assumed optimum glazing conditions (see Box - The Analysis, The Assumptions). The less energy-efficient most popular and standard (current practice) singlewide models exceeded MCS target energy use requirements by a factor of nearly two and three, respectively.

All 12 plants produced sufficient numrars of double-wide homes; in fact double-wides represented at least $70 \%$ of production in these plants. Average floor area was calculated at 1,478 sq.ft., varying from a low of 1,232 sq.ft. to a high of $1,680 \mathrm{sq}$. $\mathrm{ft}$. In the case of doublewides, the bet? available home did not quite meet MCS re uluirements in the Seattle area and the double-wides showed similarly higher energy use in the colder climate zones. ${ }^{1}$

Analysis results are summarized in Table 8.1. It is important to bear in mind that these energy use estimates were based on optimım conditions; actual energy usage would 
THE ANALYSIS, THE ASSUMPTIONS

Because glazing affects energy performance to such a degree, the following guidelines were used to standardize the comparisons:

- The amount of glazing used for analysis was that included in the base price of the homes.

- The most popular models always increased levels of insulation at the expense of increased glazing areas.

- All best available homes used a ratio of approximately $12 \%$ glazing to floor area. If insulated cardboard air barriers were offered as an option, a value of R-1 was added to the wall insulation and the infiltration rate was reduced by $25 \%$.

- Glazing was assumed to face $50 \%$ south, $20 \%$ east, $20 \%$ west, and $10 \%$ north. Homes were always aligned east-west.

These conditions are ideal and did not reflect glazing conditions in actual practice.

on actual glazing area, exposure, and alignment on the site. The values shown are averages of a great number of models but, as the standard deviation figures indicate, energy performance characteristics were relatively similar across a range of homes produced by a cross-section of the region's manufacturers. As used in this table, the term "standard" indicates current practice.

\section{The Council Steps In}

The Council had long been interested in the development of the manufactured housing project and had advocated and supported the effort in many ways. Its 1986 Plan called for Bonneville to foster regional cooperation in all its activities, and singled out manufactured housing as a specific area for focusing such effort. The goal to achieve $50 \%$ penetration of new energy-efficient manufactured housing built to the MCS by 1990 had not changed and both in public and in private the Council had strongly supported the efforts of the first Manufactured Housing Work Group. Now it appeared that Bonneville's budget cuts could hamper these efforts.

The Ccuncil was sympathetic to the problems. As quoted in the Council's Northwest Energy News, the Council's executive director said (NWPPC 1986a):

We understand the difficulties Bonneville is facing, and we agree on the need to review spending levels with care....At the same time, we're concerned about the effect the proposed cuts may have on the progress of conservation and fish and wildlife programs.

Actually, the Council was taking a long, hard look at several programs, the manufactured housing program among them (NWPPC 1986a):

The Council staff is analyzing the new budzets. We have questions about the adequacy of funding for new commercial buildings, manufactured housing and the assessment of conservation data....It will also be important for Bonneville to work with organizations that are implementing conservation programs so that the region doesn't lose capability in that sector.

Following the Manufactured Housing Work Group Meeting in the fall of 1986, the Council had begun to develop its own assessment of the situation. Working with Bonneville's Planning Branch and with the project's long-term manager in the Consumer Products and Services Branch, the Council undertook a comprehensive analysis of the situation.

Besides opportunity, there was momentum -nay, enthusiasm -- for the project. If budget cuts were to be made, it seemed that -- money or not -- it would not be prudent to risk losing the good start that had been made, and the nearly 4 years of staff investment that had 
TABLE 8.1 - Space Heating Energy Use Analysis Summary ${ }^{1}$

\begin{tabular}{|c|c|c|c|c|}
\hline \multirow{3}{*}{$\begin{array}{c}\text { Climate Zone } \\
\text { and } \\
\text { Model }\end{array}$} & \multicolumn{4}{|c|}{ Energy Use (kWh/sq.ft./yr.) } \\
\hline & \multicolumn{2}{|c|}{$\begin{array}{c}\text { Single-Wide } \\
\text { (average area } 844 \text { sq.ft.) }\end{array}$} & \multicolumn{2}{|c|}{$\begin{array}{c}\text { Double-Wide } \\
\text { (average area } 1478 \text { sq.ft.) }\end{array}$} \\
\hline & Average & Std. Dev. & Average & Std. Dev. \\
\hline $\begin{array}{l}\text { Climate Zone } 1 \\
\text { Standard } \\
\text { Most Popular } \\
\text { Best Available } \\
\text { MCS Energy Use } \\
\end{array}$ & $\begin{array}{l}5.56 \\
3.96 \\
1.96 \\
2.00 \\
\end{array}$ & $\begin{array}{l}1.01 \\
0.86 \\
0.48\end{array}$ & $\begin{array}{l}5.84 \\
4.77 \\
2.69 \\
2.00 \\
\end{array}$ & $\begin{array}{l}1.26 \\
0.54 \\
0.53\end{array}$ \\
\hline $\begin{array}{l}\text { Climate Zone } 2 \\
\text { Standard } \\
\text { Most Popular } \\
\text { Best Available } \\
\text { MCS Energy Use } \\
\end{array}$ & $\begin{array}{l}9.28 \\
6.92 \\
4.18 \\
\underline{2.60} \\
\end{array}$ & $\begin{array}{l}1.39 \\
1.27 \\
0.61\end{array}$ & $\begin{array}{l}8.90 \\
7.50 \\
4.64 \\
2.60 \\
\end{array}$ & $\begin{array}{l}1.73 \\
0.81 \\
0.68\end{array}$ \\
\hline $\begin{array}{l}\text { Climate Zone } 3 \\
\text { Standard } \\
\text { Most Popular } \\
\text { Best Available } \\
\text { MCS Energy Use }\end{array}$ & $\begin{array}{l}11.12 \\
9.07 \\
5.21 \\
3.20 \\
\end{array}$ & $\begin{array}{l}1.60 \\
1.67 \\
0.70\end{array}$ & $\begin{array}{c}10.59 \\
8.99 \\
5.65 \\
3.20 \\
\end{array}$ & $\begin{array}{l}1.22 \\
0.96 \\
0.78\end{array}$ \\
\hline
\end{tabular}

been devoted to bringing the project to this point. More than that, there had been nearuniversal agreement that more needed to be learned. Gaining this knowledge without further delay was relatively cheap and would put the region in a good position to make the necessarily greater investments in manufactured housing later -- when Bonneville's coffers would presumably begin to refill. All roads began to lead to a demonstration program.

\section{The Council's Overview}

The Council pressed forward with its study, releasing the overview on June 3,1987 , just prior to the second scheduled meeting of the Manufactured Housing Work Group (see Box). This summary provided a useful reference and background on the essential facts bearing on the project; it will also provide a useful review within this narrative. In most cases the data have been updated and revised from the original information provided in the initial Bonneville reports (NWPPC 1987a).

- The HUD code Industry - In 1987, there were 17 plants manufacturing HUD code homes in the Northwest: eight in Oregon, five in Idaho, and four in Washington. There were no plants in Montana. Combined production in 1985 was approximately 11,425 units; this dropped in 1986 to just under 9,700 units because of depressed regional economic conditions and waning oil exploration activity in Alaska. Based on 1985 statistics, regional production breakdowns by state were Oregon (51\%), Idaho (36\%), and Washington (13\%).

- Regional HUD code Sales and Home Characteristics - Approximately $15 \%$ of the units produced in 1985 were exported, mostly to Utah and Alaska. The remaining units were sold and sited within the region. 


\section{THE SECOND WORK GROUP MEETING - JUNE 1987}

Even while the Council and Bonneville were attempting to determine the next steps in the manufactured housing project, two points were clear:

- Some type of demonstration program was needed to bring the industry up to speed and to determine the cost parameters of the upgrade program.

- Whatever decisions were to be made in manufactured housing must involve the work group.

The call went out scheduling a meeting for June 11,1987 . Not quite as early as some had hoped; not quite as late as some had feared.

As shown in Table 8.2 , almost $85 \%$ of new manufactured homes were sited in Oregon and Washington. About $75 \%$ of these were multisection units. In the region as a whole, $68 \%$ of new manufactured l.omes were multi-section units (the majority of units sited in the colder portions of the region were single-section models). This $68 \%-32 \%$ breakdown was nearly the reverse of the national market; multi-section homes accounted for only one-third of all HUD code unit sales nationally.

- Share of Market - Based on 1984 housing starts, HUD code housing accounted for $29 \%$ of all new single-family housing starts in the region. Penetration ranged from its highest levels in western Montana (45\%) to lower levels in Idaho (34\%), Oregon (32\%), and Washington (26\%). (There were, however, areas in Washington and

Oregon where utilities reported much higher penetration rates. Also, percentages can be misleading; the absolute number of homes in Washington and Oregon was much greater.)

- HUD Code Home Characteristics - As indicated, nearly two-thirds of new HUD code homes sited regionally were multisection units, averaging about 1,485 sq. ft. in size. Single-section units averaged about 900 sq.ft. in size. In $1982,86 \%$ of the units sold were electrically heated; during the current year (1987), the industry projected an increase to $93 \%$.

- Insulation Levels - Table 8.3 shows the insulation levels projected for installation in new HUD code homes built in 1987. For purposes of comparison, other insulation levels are shown as well: the current Federal Manufactured Housing Construction and Safety Standard levels, HUD's minimum property standards (MPS) for site-built housing, the Oregon and Washington codes for site-built homes, and MCS.

- Electric Space Heating Consumption - The Council's overview concluded with an update of Bonneville's original consumption estimates, noting that consumption data was not yet available from the 39 upgraded homes (the 5 test homes and the 34 Tulalip homes) Bonneville had already placed in the region. Lacking real-world data, the space heating energy use of typical HUD code homes was estimated using a computer simulation model for locations representing the region's three climate zones. The estimates assumed an average indoor temperature of $65^{\circ} \mathrm{F}$ and internal heat gains of $3,000 \mathrm{Btu} / \mathrm{hr}$.

Shown in Table 8.4, the Council's calculations differ in detail but not in direction from Bonneville's original "rough-cut" estimates of energy use characteristics and potential. The differences were due to several factors -- a revision in average areas, more refined glazing assumptions, and revisions in the estimated energy use of MCS site-built homes.

The Council concluded that significant energy savings were "technically available" by increasing the energy efficiency of new HUD code homes. If, for example, over the next 20 years $85 \%$ of new HUD code homes were built 
TABLE 8.2 - HUD Code Manufactured Homes Sited in Northwest (based on 1985 State Bureau of Licensing Reports)

\begin{tabular}{||l|c|c|c|c|c||}
\hline & Oregon & Washington & Idaho & $\begin{array}{c}\text { Western } \\
\text { Montana }\end{array}$ & Total \\
\hline Single-Section & 431 & 1,583 & 617 & 342 & 2,973 \\
\hline Multi-Section & 1,552 & 4,206 & 381 & 141 & 6,280 \\
\hline Total & 1,983 & 5,789 & 998 & 483 & 9,253 \\
\hline $\begin{array}{l}\text { Percent of } \\
\text { manufactured } \\
\text { homas sited in } \\
\text { region }\end{array}$ & $(21 \%)$ & $(63 \%)$ & $(11 \%)$ & $(5 \%)$ & $(100 \%)$ \\
\hline \hline Source: NWPPC 1987a &
\end{tabular}

TABLE 8.3 - Average New HUD Code Home Insulation Level Comparisons

\begin{tabular}{|c|c|c|c|c|c|}
\hline Standard & Ceiling & Wall & Floor & Window & Door \\
\hline Current Practice & $R-17$ & $\mathrm{R}-12$ & $R-10$ & R-1.3 & $\mathrm{R}-5$ \\
\hline FMHCSS Minimum & R-11 & $\mathrm{R}-7$ & $\mathrm{R}-7$ & $\mathrm{R}-1.3$ & $R-2.5$ \\
\hline HUD MPS & $R-38$ & $R-19$ & $R-19$ & $\mathrm{R}-1.7$ & $R-5$ \\
\hline Oregon Code & $\mathrm{R}-38$ & R-19 & R-19 & $\mathrm{R}-1.3$ & $R-2.5$ \\
\hline Washington Code & R-38 & R-19 & R-19 & R-1.7 & R-2.5 \\
\hline $\begin{array}{l}\text { MCS } \\
\text { Climate Zone } 1 \\
\text { Climate Zone } 2 \\
\text { Climate Zone } 3\end{array}$ & $\begin{array}{l}R-38 \\
R-38 \\
R-49\end{array}$ & $\begin{array}{l}R-19 \\
R-24 \\
R-27 \\
\end{array}$ & $\begin{array}{l}R-30 \\
R-30 \\
R-? U\end{array}$ & $\begin{array}{l}R-2.5 \\
R-2.5 \\
R-2.5\end{array}$ & $\begin{array}{l}R-5 \\
R-5 \\
R-5\end{array}$ \\
\hline $\begin{array}{l}\text { Maximum Options } \\
\text { Single-Section } \\
\text { Multi-Section } \\
\end{array}$ & $\begin{array}{l}R-38 \\
R-38 \\
\end{array}$ & $\begin{array}{l}\mathrm{R}-19 \\
\mathrm{R}-25 \\
\end{array}$ & $\begin{array}{l}\mathrm{R}-22 \\
\mathrm{R}-22 \\
\end{array}$ & $\begin{array}{l}R-2.5 \\
R-2.5\end{array}$ & $\begin{array}{l}R-10 \\
R-10 \\
\end{array}$ \\
\hline \multicolumn{6}{|c|}{$\begin{aligned} \text { FMHCSS } & =\text { Federal Manufactured Housing Construction and Safety Standards } \\
\text { MPS } & =\text { minimum property standards } \\
\text { Source: } & \text { NWPPC 1987a }\end{aligned}$} \\
\hline
\end{tabular}


TABLE 8.4 - Projected Electric Space Heating Use for New HUD Code Homes

\begin{tabular}{|c|c|c|c|c|}
\hline \multirow[b]{2}{*}{$\begin{array}{l}\text { Regional Average } \\
\text { (1300 sq.ft.) }\end{array}$} & \multicolumn{3}{|c|}{$\begin{array}{l}\text { Annual Electric Space Heating Use } \\
\text { (kWh/sq.ft./yr) }\end{array}$} & \multirow{2}{*}{ AVERAGE } \\
\hline & $\begin{array}{c}\text { Zone } 1 \\
\text { (Seattle) }\end{array}$ & $\begin{array}{c}\text { Zone } 2 \\
\text { (Spokane) }\end{array}$ & $\begin{array}{c}\text { Zone } 3 \\
\text { (Missoula) }\end{array}$ & \\
\hline HUD FMHCSS & 8.2 & 12.6 & 15.0 & 10.0 \\
\hline Current Practice & 5.9 & 9.4 & 11.1 & 7.4 \\
\hline Best Available & 2.3 & 4.3 & 5.3 & 3.1 \\
\hline HUD MPS (Site-Built) & 3.0 & 5.4 & 6.6 & 4.0 \\
\hline Oregon Code & 4.4 & 7.1 & N/A & N/A \\
\hline Washington Code & 3.6 & 5.5 & N/A & N/A \\
\hline MCS (Site-Built) & 2.1 & 3.5 & 3.9 & 2.6 \\
\hline \multicolumn{5}{|c|}{$\begin{array}{l}\text { FMHCSS = Federal Manufactured Housing Construction and Safety Standards } \\
\text { MPS = minimum property standards } \\
\text { Source: NWPPC 1987a }\end{array}$} \\
\hline
\end{tabular}

to the MCS for site-built housing, regional demand savings would be approximately 110 average megawatts valued at just over $\$ 925$ million.

\section{The June Meeting}

While the Council was developing its overview, Bonneville was reviewing various scenarios for conducting a demonstration test. Just before the Work Group meeting, Bonneville mailed each potential participant a packet that contained an outline of the project's background, its goals and objectives, a listing of those involved in any demonstration project, and three design options for the Work Group to consider. ${ }^{2}$

The background simply recapitulated what most participants already knew -- that Bonneville intended to promote increased energy efficiency in HUD code homes. To accomplish this, Bonneville proposed a demonstration project, involving the manufacture of up to 150 homes, beginning in the spring of 1988. These homes would be monitored during the 1988-1989 heating season and the level of regional cost-effectiveness would be determined by the fall of 1989 . A regional project would then be designed based on these results.

The goal reflected this approach. The objectives were more specific: ${ }^{2}$

- Increase market demand for the energyefficient HUD-code homes manufactured during the demonstration:

- Offer to pay all incremental costs of manufacturing homes [in demonstration] beyond the current levels of energy efficiency;

- Advertise the offer to individuals considering the purchase of a new HUD-code home.

- Assure the availability of HUD-code homes manufactured to higher levels of energy efficiency: 
- Offer training to manufacturers, dealers, and inspectors on methods of achieving higher levels of energy efficiency in manufactured homes;

- Certify demonstration homes that meet the established standards before payment of incremental costs.

The background packet identified the several groups involved in the proposed demonstration project: consumers, manufacturers, dealers, trade associations, suppliers, utilities, SEOs, and IPIAs. It noted that the manufacturers must be convinced that any alterations would improve their product's marketability without pricing it beyond their customers' ability to pay. It was also noted that SEOs could be instrumental in helping to conduct any new programs. SEOs were carrying out training and technical assistance roles in Bonneville's Super Good Cents program. The Washington State Energy Office (Washington SEO) was playing a major role in Bonneville's new Residential Construction Demonstration Project (RCDP).

\section{The Options}

Bonneville presented three demonstration project options for consideration by the Work Group. The tasks for any version of these projects would be the same (see Box Demonstration Project Activities): ${ }^{2}$

\section{DEMONSTRATION PROJECT ACTIVITIES}

- Design and conduct all promotional activities.

- Develop and conduct training for manufacturers, dealers, and inspectors (and utilities if involved by the option).

- Certify all qualified homes.

- Pay the incremental cost for all certified homes.

- Collect demonstration data, evaluate and determine cost-effectiveness level.
- Bonneville as Lead Agent - Bonneville would control and operate the entire project, delegating or contracting for supporting services. The advantages were that Bonneville had the resources, the contacts, and the experience to develop such a program. The chief negative factor was that a strong central program could limit or discourage public and private participation.

- SEOs as Lead Agent - This alternative would operate similarly to Bonneville's new RCDP under which Bonneville contracted with SEOs for program administration and operation. Bonneville would maintain responsibility for conducting the promotional effort and for analyzing data. The advantages were that SEOs were already under contract and could quickly develop a regional project. Through the RCDP program, the Washington SEO was familiar with energy-efficient home construction and training and certification processes.

- The Super Good Cents Look-Alike - Utilities participating in the Super Good Cents program would assume a more important role in operating the demonstration program, inspecting and certifying all homes sited in their service territory, and making payments to the owner (with reimbursement by Bonneville). Bonneville would retain responsibility for promotion, training, and data collection/analysis. The advantages of this approach were that utilities had personnel who were experienced in new home construction, cornmunication channels were already established, and the utilities involved were already involved in the Super Good Cents certification process. The negatives were that utilities lacked experience in dealing directly with manufacturers who were likely to be located outside the utility service territories, utility conservation operations were already generally understaffed, and new extra duties were likely to be unattractive. 
The consensus of the meeting was that Bonneville should act as the lead agent. However, elements of the other options were attractive -- the general feeling was that SEOs definitely had a role to play, the Super Good Cents look-alike was attractive from a marketing point of view to many of the manufacturers, and the RCDP experience led some participants to suggest that rather than serving as a model for the demonstration project, it could be considered the vehicle.

\section{A Long, Hot Summer}

One point was clear following the events of June (see Box - The Council Takes a Stand). There would be no turning back. While concern about any direct move to a higher thermal standard for manufactured housing may have been widespread it was not universal. Some participants had argued for no further testing -- this view maintained that sufficient proof was already in hand. However, if a regional test were to be undertaken, the meeting indicated there was clearly enough enthusiasm among manufacturers to support some type of demonstration effort. Bonneville had committed its resources to the effort and the only remaining questions now concerned not "whether" but "how."

How indeed. After further discussion oneon-one with members of the growing group of interested participants and further analysis by Bonneville staff, the project group developed a proposed comprehensive strategy that was mailed to each of the Work Group participants. ${ }^{3}$

\section{Super Good Cents participating utilities} will be permitted the option of certifying HUD-code homes meeting the Super Good Cents specifications and paying the financial incentive available under the current provisions of the program; and

2. Bonneville will establish a cost-effective limit for HUD-code homes using thermal relations developed from the Residential Standards Demonstration Program data

\section{THE COUNCIL TAKES A STAND}

The Council's analysis effort, its overview and its demonstrated strong support for the project in the work group and Bonneville's day-to-day activities were buttressed by other strong actions. The June 1987, Council meeting in Ashland, Oregon, featured a manufactured housing panel that highlighted and focused the region's attention on the issue (NWPPC 1987b). Among the panelists was the Director of Bonneville's Residential Programs Division. The Northwest Energy News devoted nearly half its summer issue to manufactured housing (NWPPC 1987c).

At this time it appeared that the matter might still be resolved via the regulatory path. On May 19, 1987, a Congressional committee had adopted an amendment to the Housing and Community Development Act that would require HUD code housing to meet the same minimum thermal performance standards as those required for site-built houses. Just a week earlier, HUD proposed a draf rule that would remove thermal standards from the federal Manufactured Housing Construction and Safety Standards and place them under local jurisdiction (NWPPC 1987b).

and using cost data developed by Pacific Northwest Laboratory and regional HUDcode home manufacturers.

3. Bonneville will pursue the inclusion of HUD-code homes as one innovation to be demonstrated in the RCDP. This step will serve two primary purposes:

a. Assist a few manufacturers in the design of homes to the MCS performance levels and in the initial production of such homes. (Our view is that by themselves, the standard SGC incentives would not have been sufficient to help manufacturers gain this initial experience.)

b. Produce energy performance and cost data that could be used to verify the 
RSDP thermal analysis and the cost data previously developed.

One of the most intense activities underway was the work of a special task group that modified the Super Good Cents specifications developed for site-built homes. ${ }^{4}$ The group -made up of representative and knowledgeable Bonneville staff, SEO personnel, industry experts, Council analysts, and others -- worked diligently throughout the summer to develop these specifications by early fall. Another Work Group meeting had been scheduled for September 24, 1987, with the following goals: ${ }^{3}$

- Discuss and finalize the strategy proposed by Bonneville.

- Evaluate procedures for certifying HUD code homes as Super Good Cents.

- Review the modified specifications for Super Good Cents HUD code homes.

- Study and assess the proposed research program to establish the regionally costeffective level of energy efficiency in HUD code manufactured housing.

\section{Back to a Technical Orientation}

In the meantime, Bonneville was undergoing changes in organization (see next chapter) in an

\section{End Notes}

1 Internal report on current practice of HUD Code home manufacturers. File copy handdated January 9, 1987. Bonneville Power Administration, Portland, Oregon.

2 Letter on the agenda and options fer consideration at the scheduled June 11 , 1987, Work Group meeting from the Chairman, Manufactured Housing Work Group [Chief, Consumer Products and Services Branch (KRP)] to the Work Group members. May 29, 1987. Bonneville Power Administration, Portland, Oregon. agency-wide effort to achieve more efficiency. The events of the summer were, again, timely. They ensured that the project would have high priority regardless of how Bonneville would ultimately be organized. In fact, when the objectives and organization were finally settled in the fall, funding and operation of a major regional test of 150 manufactured homes was assured under RCDP auspices. The principal manager of the manufactured housing project would move into the newly formed Residential Technology Section where the RCDP would be administered.

\section{$* * * * *$}

It was nearly a "round trip." The project that began as an engineer's task in the Technical Support Section ended up, nearly 4 years later, as an engineer's task in the Residential Technology Section. But by now, through a lot of effort, it was a different project. It had demonstration homes, it had "real-world" data and experience, it had clearcut goals, objectives, and deadlines -- and now it had friends (or at least acquaintances). Lots and lots of friends (or at least acquaintances).
3 Letter on the proposed strategy for manufactured housing based on the results of the June 11,1987 , Work Group meeting from the Chief, Consumer Products and Services Branch (KRP), to the work group members. August 13, 1987. Bonneville Power Administration, Portland, Oregon.

4 Letter on the latest revision and timetable for completion from the Chairperson, Manufactured Housing Technical Specifications Task Group, to the task group members. August 19, 1987. Bonneville Power Administration, Portland, Oregon. 


\section{CHAPTER 9: RCDP -- Readying an Innovation}

It wasn't until March of 1988 that the first RCDP test home rolled off a regional manufacturer's assembly line and then rolled again over the snow-covered Cascades and sleek, black, undoubtedly rain-drenched pavement to reach its little corner of the world -- Ephrata, Washington. Not only extra insulation filled its shell; an incredible investment in energy and aspiration on the part of several organizations and individuals was built into the home riding on that road that day, as well. It had taken months of effort during the last half of 1987 to initiate the test in January 1988 -- and a couple of months after that to actually build the first Super Good Cents home to be tested under the RCDP program.

\section{Bonneville Reorganizes}

If the pace weren't frantic enough, the events of 1987 took place in the context of a mammoth upheaval at Bonneville. Throughout most of the year, the agency was moving to a new headquarters and engaged in a total reorganization to achieve what was called "the $\mathrm{MEO}^{\prime \prime}$-- the most efficient organization. Understandably, Bonneville morale was low and frustration was high until the MEO was finalized in the fall. When the process was finished, Bonneville was reorganized into six functional offices and not one of them was Conservation!

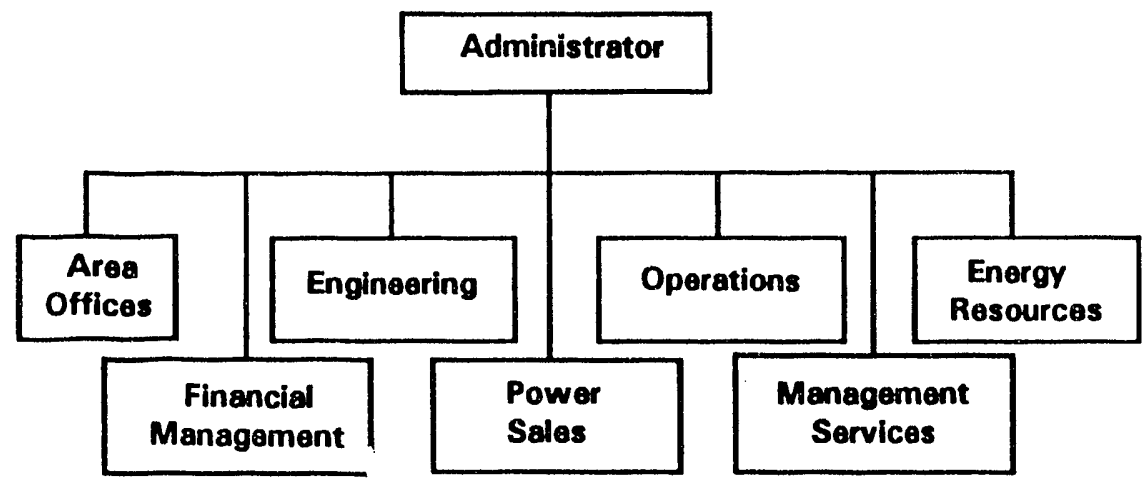

Bonneville Power Administration Offices

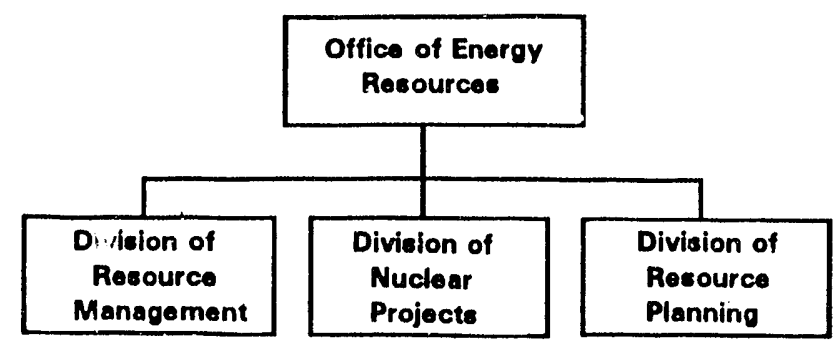

Office of Energy Resources 
A new office, the Office of Energy

Resources, combined the functions of the previous Office of Conservation with other key functions previously carried out by the Offices of the Administrator, Power Management, and Engineering and Construction. From now on, Bonneville clearly defined conservation as a power resource to be acquired like any other -a resource that had come of age.

The Office of Energy Resources was organized into three separate divisions -Resource Management, Nuclear Programs, and Resource Planning. Resource Management was responsible for the design and management of conservation programs in all sectors. This division included the Residential Programs Branch which, in turn, also consisted of three sections -- New Home Construction, Existing Construction, and Residential Technology. Among its other responsibilities, the Residential Technology Section managed the RCDP (BPA 1989a).

\section{Manufactured Housing Becomes an "Innovation"}

When the dust settled in the fall, the organization was established; the course of the manufactured housing project was also settled in the fall meetings of the Manufactured Housing Work Group. The Council's influence and the Work Group's cooperation ensured that the project would definitely be funded and would definitely continue. It had been agreed that a major regional test of 150 homes would begin as soon as possible in 1988 under RCDP auspices.

Because manufactured housing was ..ow also eligible for incentives under the ongoing Super Good Cents program, it was a component of both the New Construction and Residential Technology Sections. As a practical matter, however, the "main event" was the RCDP demonstration effort; this would remain the case until the questions being asked by RCDP were answered.

\begin{tabular}{l} 
RCDP - A SUMMARY \\
Cycles Scheduled January 1988 \\
Cycle I: \\
165 Homes Built \\
- Air-to-Air Heat Exchangers (AAHXs) with Supply \\
Air Tempering \\
- Exhaust Heat Pumps \\
- Energy-Efficient Modular Homes \\
- Airtight Drywall Approach (ADA) \\
- High R-Value Walls. \\
Cycle II: \\
190 Homes Built \\
150 Manufactured Homes Sited \\
- Future House \\
- Energy-Efficient Appliances \\
- Volume Builder \\
- Active Ventilation Systems \\
- Air Leakage Control \\
- Manufactured Housing \\
Cycle III: \\
To be scheduled. \\
\hline
\end{tabular}

What, in fact, was the RCDP? In October 1985, when the Council issued its Draft Power Plan, the Bonneville Power Administration established a continuing effort to examine new residential building techniques and product innovations that indicated potential to advance the state of the art in constructing new energyefficient electrically heated housing. This effort was called the Residential Construction Demonstration Project -- very soon, nearly everyone in the Pacific Northwest energy community knew it simply as RCDP (NWPPC 1985).

The stated objectives of the RCDP were (BPA 1991b) as follows:

Primary Objective: To provide the most comprehensive technical arm for Bonneville's Super Good Cents and Northwest Energy Code Programs. 
Secondary Objective: Obtain documented cost and energy performance data, and data associated with a specific research area which will assist Bonneville and the region in making the most accurate assessments for constructing homes that meet energy-efficient levels specified by Bonneville.

\section{Specific Objectives:}

- Develop and/or refine predetermined conservation techniques and innovations;

- Examine predetermined conservation techniques and innovations by gathering specific data on reliability, cost effectiveness, and marketability;

- Introduce the use of innovations which show potential to be reliable, cost effective, and marketable; and

- Disseminate information gathered from the project which is useful to the shelter industry or to policy makers in the region.

At the time the manufactured housing project was scheduled to participate in the RCDP process, the program was well underway. A format, a methodology, a language had evolved. Specific techniques, issues, and products studied were called "innovations" and these were studied in "cycles." Cycle I was underway at the beginning of 1988 (see Box RCDP) and Cycle II was nearly "locked up." The need to resolve RCDP planning in time for the scheduled start of Cycle II had been, in fact, another pressure on the manufactured housing project during the summer of 1987.

\section{Making the State Energy Office Fit}

Bonneville had contracted with the Washington SEO for regional administration of RCDP. The Washington SEO, in turn, subcontracted with other SEOs throughout the region to help manage and implement specific projects as necessary. As a result, many of the activities of the impending manufactured housing demonstration project would be handled by the SEOs.

Prior to the decision to conduct the demonstration effort as part of RCDP, the SEOs had not been directly or heavily involved with the manufactured housing project. Liaison with state agencies had generally involved cnde and licensing officials but not energy specialists. The addition of SEOs at first was simply a consequence of choosing RCDP as the demonstration vehicle and not a model. Initially, the addition of SEOs to the "mix" was even viewed as a possible administrative burden; as events were to unfold, it was clear that the addition of the SEOs was a master stroke -- another example of the serendipity that occasionally seemed to bless the project.

The SEOs were able to shoulder a great deal of the administrative burden -- a chore that grew to be much greater than anticipated. They also extended the outreach of the program in several directions. The offices were often able to focus and serve as a sounding board for specific issues relating to local areas or individual manufacturers. They increased the opportunity and resources for liaison with manufacturers and served as a vehicle for important feedback. They helped to siphon off some of the frustration and confusion that developed between Bonneville and the manufacturers. And, once brought up to speed, they numbered among the program's most dedicated advocates -- true believers.

SEO involvement had begun in 1987 , as soon as it was known that the manufactured housing project would now be known as an RCDP "innovation." Familiar with the Super Good Cents specifications, they helped to shape the site-built Super Good Cents specifications to suit industry conditions and they learned about the industry in the process. Because they had staff resources available, were physically closer to the manufacturers, and could translate their experience with building contractors to working with manufacturers, the decision was made that 
the SEOs would certify the upgraded homes as meeting "Super Good Cents specs."

\section{Developing Super Good Sensible Specifications}

From the beginning it was known that there were distinct differences between typical HUD code manufactured homes and site-built homes. To some extent, this was the reason that HUD code homes had not been included in the initial Power Plan in 1983. Allowing for these differences in the Super Good Cents specifications was a major effort -- and a major achievement -- for the project. By the time the RCDP test was being designed, enough was known about the industry -- and manufacturers themselves were so involved in the process -that there was never any thought of simply imposing the Super Good Cents standards on manufactured homes.

A special task group worked through the summer of 1987 to isolate these differences, decide which ones were critical, and redesign the specifications without compromising the energy efficiency of the final product. What were these differences (BPA 1988c)?

Construction Constraints - Manufactured homes have height limitations because they must move under bridges and overpasses when transported from the factory to the site. As a result, roof pitches of HUD code homes were shallow, usually a ratio of about 3 to 12. Above the walls, the cavity space was about 5 inches, increasing to about 40 inches at the highest point (usually at the center of the home). These characteristics apply to flat scilings; vaulted ceilings had even smaller cavities -- usually about a 16-inch space above the center ridge beam.

Ceiling Insulation - Manufacturers typically installed insulation levels of about R-16 in the ceiling although many offered upgrades to R-22 or more as a customer option. In a manufactured home bvilt to Super Good Cents specifications, roof cavities were usually filled to capacity at insulation levels of R-30 in vaulted ceilings and $R-38$ in flat ceilings although there were exceptions. Some manufacturers could increase insulation levels by using higher density insulation (which has a greater R-value) or by modifying the roof truss system to enlarge the cavity.

Floor Insulation - Most regional manufacturers used a 2 in. $x 6$ in. floor joist resting on an R11 "belly blanket." Belly blankets, usually 6 feet wide extending the length of the floor, were placed under the floor joists before the steel frame -- the undercarriage used to transport the homes -- was attached. A tough, rodent-proof material called "bottom board" supported the blanket. When the steel frame was attached, the insulation was compressed between the rails of the frame and the floor joists; the innovative solution developed for the Super Good Cents/RCDP manufactured homes was to place $R-19$ or $R-22$ batt insulation between the floor joists as vis done in site-built homes. The combination of the batt insulation and the belly blanket yielded a nominal R-30 level of insulation.

Wall Insulation - There was no basic difference between wall frame construction in site-built and manufactured homes. Typically, both homes used 2 in. $x 6$ in. studs, 16-inch on center, and insulated walls to levels ranging from R-19 to R-22. Some of the region's manufacturers used a 2 in. $x 4$ in. stud for their standard models, but all of them converted to the heavier construction for the Super Good Cents/RCDP homes. Although the existing specifications would allow the option of using insulated sheathing, no manufacturers indicated they would follow that approach.

Windows - In 1987 and 1988, the windows typically used by the industry did not meet Super Good Cents requirements and were similar to those used in site-built housing several years earlier. Windows played a critical role in therma, performance and the Super Good Cents requirements required most manufacturers to seek out new suppliers -- 
forgoing their normal volume savings. From the beginning it was known that windows would account for a major part of the expense of energy- efficiency upgrades.

For customers wanting more glazing area, the Super Good Cents homes cost even more. The R-values shown for walls, ceilings, and floors were the maximum that could be achieved without making major structural changes or using exotic (read "expensive") materials. All cavities were filled to capacity. Such a home could achieve Super Good Cents energy-efficiency levels with glazing-to-floor ratios of about $12 \%$. However, manufacturers and dealers stressed that much of the sales volume consisted of homes exceeding this $12 \%$ ratio -- people like lots of windows!

Manufacturers and dealers warned that home buyers demanding extra glazing were likely to choose this option over qualifying their homes under the Super Good Cents/RCDP program. To incorporate additional glazing area and still qualify in terms of energy efficiency, a home would have to use any or all of several costly alternatives -- windows of even higher quality, altered ceiling and wall construction techniques, or unusual insulation materials.

Doors - Doors typically used by the industry would not meet the air leakage requirements of Super Good Cents and most manufacturers would have to use a better quality door to qualify their homes.

Heat Pump Option - Super Good Cents offered a heat-pump option that was extended to manufactured homes. Manufacturers could produce homes with less insulation, more glazing, or lower quality windows by using more efficient (and more expensive) electric heat pumps as their heating system.

Ventilation Requirements - A major difference between Super Good Cents and current practice in either site-built or manufactured homes was the requirement for frestı air ventilation. Because Super Good Cents homes are tighter, they were required to bring in "controlled" fresh air to remove indoor air pollutants and moisture. This can usually be achieved using wall ports or slotted windows in conjunction with a ventilation fan controlled by a central timer or a humidistat control.

\section{VENTILATION IN HUD CODE HOMES}

Two factors distinguished manufactured homes. First, tests to date had shown that manufactured homes, in current practice, had relatively low infiltration rates, performing moderately better than site-built homes. Second, HUD already required manufacturers to offer a ventilation option to buyers and specified the approved systems. Because these systems did not meet SGC specifications and the HUD code could not be pre-empted, some SGC/RCDP homes were equipped with two ventilation systems. There was no way around this problem.

\section{The Super Good Cents/RCDP Technical Specifications}

Specifications tailored to the conditions and construction practices of the industry were presented at the September 1987 meeting of the Manufactured Housing Work Group, and the specifications were revised and finalized in November. In total, these comprised a goodsized "book" detailing the procedures for approval as well as the performance requirements. The requirements were outlined for each of the region's clinate zones and for each major construction component -- walls, ceilings, floors, etc.

There were two paths to comply with the Super Good Cents specifications and manufacturers could choose either one of them. The most commonly used path in site-built construction was the thermal performance path; the alternate path was called the energy budget path. The specifications ware based on climate zones so the requirements for areas with more severe climates called for larger amounts of insulation. The climate zones were those 
outlined in the MCS - those described in Chapter 3.

To qualify via the thermal performance path, a "reference heat loss rate" had to be calculated using the heat loss values for each major construction component outlined in Table 9.1. Using these assumed values for floor, wall, and ceiling areas, and a window area equal to $15 \%$ of the heated floor area, the reference heat loss rate was compared to the heat loss rate calculated for an Super Good Cents/RCDP home seeking approval.

The energy budget path was used for homes that were to be fitted with heat pumps. The reference heat loss rate was input to a computer simulation model that predicted the heating energy required by the proposed home at its projected site. The home could then be modeled using the same program. Because the heat pump will produce more heat per kilowatthour, heating requirements are offset and the manufacturer could construct a home with less insulation or more glazing than a similar home heated by conventional resistance heating.

A major difference between manufactured and site-built homes, one requiring development of a whole new Super Good Cents methodology, was the fact that manufactured homes were transported and subsequently set up on site. This had long been a concern and the research to date on the initial five test homes and the Tulalip Reservation homes had shown that set-up procedures were critical. One of the major factors in achieving the low infiltration rates that contribute to energy efficiency would be the proper set-up of Super Good Cents/ RCDP homes.

Accordingly, procedures were developed that called for the addition of ground vapor barriers, skirting (with ventilation), insulation of heating crossover ducts, and sealing of the marriage line (the surface where multiple-section homes were joined). These became part of the Super Good Cents specifications.

TABLE 9.1 - Component Heat Loss

\begin{tabular}{||l|c|c|c|c|c|c||}
\hline \multicolumn{7}{|c|}{ Super Good Cents Reference Values for Heat Loss } \\
\hline \hline Component & \multicolumn{2}{|c|}{ Climate Zone 1 } & \multicolumn{2}{|c|}{ Climate Zone 2 } & \multicolumn{2}{c|}{ Climate Zone 3 } \\
\hline & U-Factor & R-Value & U-Factor & R-Value & U-Factor & R-Value \\
\hline Wall & .057 & 19 & .043 & 24 & .040 & 26 \\
\hline Floor & .029 & 33 & .029 & 33 & .029 & 33 \\
\hline Windows & .39 & 2.32 & .39 & 2.32 & .39 & 2.32 \\
\hline Doors & .19 & 5.2 & .19 & 5.2 & .19 & 5.2 \\
\hline Ceiling & .032 & 38 & .032 & 38 & .021 & 49 \\
\hline \hline Source: Baylon et al. 1990 & & & & & \\
\hline
\end{tabular}




\section{Compliance Procedures}

Under the RCDP scenario, SEOs were available to provide a range of services. Because the Bonneville/Washington SEO contract had already established a pattern for regional administration of the project as well as energy office participation, SEOs were well qualified to provide these services to manufacturers, dealers, utilities conducting Super Good Cents programs, and home buyers. The services included design assistance, technical assistance, an inspection program, dealer training, and assistance to Super Good Cents-sponsoring utilities and home owners as needed (BPA 1988b).

\section{STATE ENERGY OFFICES PARTICIPATING IN} THE RCDP

Washington State Energy Office (Washington SEO)

Oregon Department of Energy (ODOE) Idaho Department of Water Resources (IDWR) Montana Department of Natural Resources (MDNR).

A key service performed by SEOs from the point of view of both the project and its participants was helping manufacturers to qualify their homes for Super Good Cents/ RCDP. This was done using the same engineering tool developed for the site-built Super Good Cents program -- the WATTSUN computer program. WATTSUN is a simulated energy performance computer model derived from SUNDAY (see Chapters 5 and 8) a numerical simulation program that uses local weather data to simulate the effect of weather on building heating requirements. WATTSUN is a simpler tool using an equation derived from numerous SUNDAY simulations to more easily estimate a building's thermal performance based on input values (Baylon et al. 1990).
Many important assumptions were built into WATTSUN, including thermostat setpoints, occupant-induced heat gains, infiltration, and (to some extent) building size. This made the program somewhat inflexible and not suited to sophisticated energy analyses. However, its relative simplicity and direct approach made it ideal for the Super Good Cents application.

By limiting the input variables, WATTSUN made it easier, more straightforward, and faster to isolate the effects of design and construction variables on energy performance. The estimated energy performance of the home might differ when analyzed using a more sophisticated simulation program such as SUNDAY -- and more exact estimates would be required later when the cost-effectiveness of the measures had to be evaluated -- but WATTSUN could evaluate and quantify the energy effects of alternate design approaches with results that paralleled and closely approximated those obtained from more complex programs.

\section{Participating Manufacturers}

A.t the start of the RCDP, a total of 17 planis manufactured HUD code homes within the region and all of them were invited to participate. Although broad-scale participation wasn't essential to the success or failure of the demonstration project, it was hoped that enough manufacturers would join the effort to provide a representative sample of the industry. The extent of participation would have a bearing on the validity of test results as well as the presumed ability of the industry to duplicate them. Naturally, if none of the manufacturers were willing to participate, the demonstration project would simply not have been feasible.

Initially, five manufacturers "signed up" to participate in the project. Ultimately, seven manufacturers operating eight of the plants in the region chose to join the program (see Box Manufacturers Participating in the RCDP). This was extremely important and encouraging because the industry as a whole is generally 


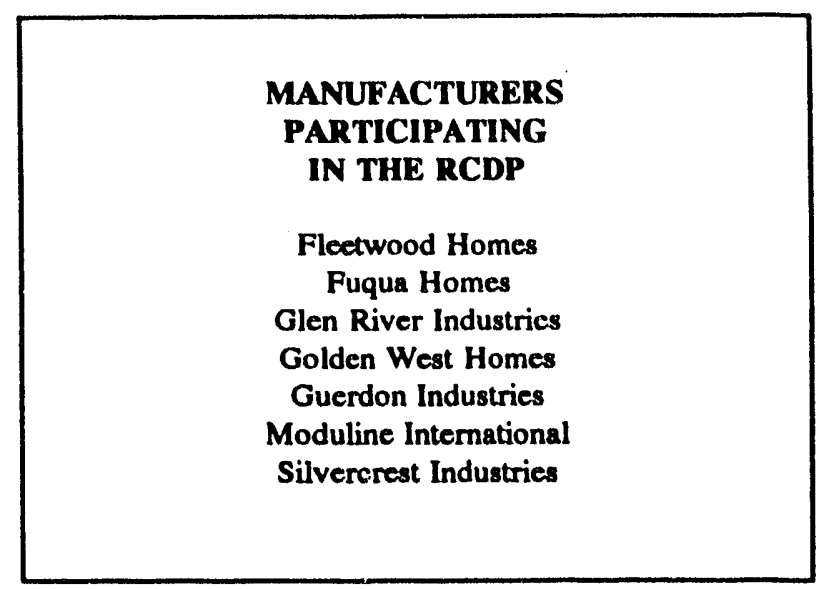

considered to be conservative -- a "wait and see" attitude is fairly widespread. Even so, the efforts to date had attracted at least some manufacturers who were willing to innovatively design, produce, and market what was essentially a new -- and risky -- product.

Beyond that, the participants represented a good cross-section of the industry. For example, the participants varied in size -- their plant production ranged from approximately 250 units per year to over 1,000 units per year. Most of the participating manufacturers operated their plants with a moderate to high degree of autonomy, even though some of them were part of a large corporate structure with headquarters outside the region (Lee and Harkreader 1989).

The relatively good start was likely to be psychologically important to the industry. If these innovators could demonstrate that they could successfully produce such homes, and if the proposed marketing effort could support their sale and acceptance by "real-world" buyers, the effort to make the HUD code homes in the Pacific Northwest energy efficient would succeed in the long term, in spite of the legal barriers, the cost barriers, and the production barriers that had originally discouraged the effort in the early 1980s.

\section{The Marketing Program}

What was the final Super Good Cents/RCDP marketing program? And, how had it evolved? It must be understood that the struggle to get to this stage had always been waged on at least two fronts -- some of the challenges facing the introduction of energy-efficient manufactured homes were technical and some involved financial and marketing issues. Advances or decisions in one area could not proceed very far without some similar progress in the other.

For example, setting up a test that involved a "massive" payment to either manufacturers or home-buyers could certainly site 150 manufactured homes quickly enough -- but such an approach would prove little and couldn't be expanded once the standard of cost-effectiveness was applied. Some degree of relatively costefficient innovation had to be developed. On the other hand, if the effort to develop relatively low-cost, feasible production techniques was followed exclusively, in the hope that costs could be kept so low that energy-saving features would "automatically" be saleable to a price-sensitive market, a lot of important time could be lost with no experience gained in marketing manufactured homes with energy-efficient features.

In the area of marketing, the fact that the project had been administered in the Consumer Products and Services Branch throughout 1986 and 1987 was binneficial. The Super Good Cents experience in advancing energy-efficient construction of site-built homes was available and close at hand. While there were legal issues and construction details that were unique to the manufactured housing industry, the marketing challenges, generally speaking, were not. Sice-built experience had clearly indicated that some incentive was required to initially launch the concept of energy-efficient housing - this was both the genesis and the essential legacy of the Super Good Cents concept and program. 
Regional characteristics were important. In some sections of the country where utility rates are high, people either are -- or could easily be educated to be -- sensitive to a home's energy performance characteristics. This is even more the case when climates are severe. In the Pacific Northwest as a whole, however, electric rates had long been low and the cost of heating a home was simply not a major issue, not something that home buyers thought about. It was not in their "vocabulary," particularly in the region's major population areas which generally are in the milder climate zones. While it is a fact that the region's electric rates had been inching up higher and higher -- and undoubtedly will continue to do so -.. in 19871988 the cost of energy was simply not yet a motivating issue.

So, clearly, a marketing stimulus had to be created. This was the experience of those who had fought the same battles in the site-built sector. Energy conservation features had always received "high marks" from marketing survey respondents and yet they consistently failed to perform in the real-world marketplace. One way to market energy efficiency in spite of this apathy is to essentially force the issue by encouraging more stringent building codes. Another way is to encourage individual home buyers to "trade up" to energy efficiency by offering an incentive for them to do so.

This latter course was the basis for the Council's and Bonneville's decision, in 1984, to develop the Super Good Cents program. By 1987, the accumulated experience with promoting energy efficiency in site-built homes via the Super Good Cents program provided an excellent guide to developing an Super Good Cents program tailored to manufactured homes when the technical issues could be resolved. In fact, manufacturers varied in their assessment of the technical problems -- no doubt reflecting their individual production practices and situations -- but they all agreed that the ability to actually sell energy-efficient homes was, in essence, much more a marketing problem than a technical one (Lee and Harkreader 1989).
And, wasn't this exactly the earlier case with site-built homes? Super Good Cents had demonstrated that a combination of training, incentives, and advertising promotion could effectively overcome the barriers of increased cost and unfamiliarity. As early as January 1986 -- nearly 2 years earlier -- a strategy to include manufactured homes in the Super Good Cents effort had been clearly indicated in a PNL report (see Chapter 6). Ultimately, perhaps no group knew the marketing challenge better than the manufacturers and they had always supported the concept of Super Good Cents support, stressing not only the incentives (clearly an important factor) but the training and advertising components of the program as well.

When finally determined, the incentives were substantial (see Table 9.2), they were designed to overcome nearly all of the initial cost barrier, and they were provided directly to manufacturers. Dealers also received incentives. In areas served by utilities participating in the Super Good Cents, home buyers and dealers received additional incentives if the utility chose to participate in the demonstration. (Not all utilities were willing to participate at this stage; some of them, like some of the manufacturers, preferred to wait until the RCDP program demonstrated that energy-efficient manufactured homes could be successfully built, sold, and sited.)

\section{Research Requirements}

As soon as the manufactured housing project was firmly scheduled as part of the next RCDP cycle, work began in late 1987 on firming up the specific research requirements of the project (BPA 1988a).

\section{Energy Use}

Energy use data would be collected from meters installed in the home:

- Heating Usage - A meter placed across the furnace electrical circuit would monitor the 
TABLE 9.2 - RCDP Incentives

\begin{tabular}{||l|r|r|c|}
\hline \multirow{2}{*}{ Incentive } & \multicolumn{3}{|c|}{ Climate Zone } \\
\cline { 2 - 4 } & 1 & 2 & 3 \\
\hline $\begin{array}{l}\text { SGC/RCDP } \\
\text { Manufacturer } \\
\text { Incentive }\end{array}$ & $\$ 2,000$ & $\$ 2,500$ & $\$ 3,000$ \\
\hline $\begin{array}{l}\text { Dealer } \\
\text { Incentive }\end{array}$ & 250 & 250 & 250 \\
\hline $\begin{array}{l}\text { Utility Dealer } \\
\text { Incentive }\end{array}$ & 250 & 250 & 250 \\
\hline $\begin{array}{l}\text { Utility Home } \\
\text { Owner } \\
\text { Incentive }\end{array}$ & 1,000 & 1,250 & 1,500 \\
\hline
\end{tabular}

heating energy used by the home.

- Water Heater Usage - A second meter would be installed to measure water heater energy use.

- Utility Metering - The utility company meter served as a third monitoring tool.

Occupants would be solicited to assist the process by reporting their thermostat temperature setpoints for day, night, and unoccupied periods. Field audits would be performed during the heating season to measure infiltration. During these audits, investigators would verify thermostat settings, window orientation, and heating system types. Finally, the data on individual homes and occupancy conditions would be correlated with actual weather data for the closest site to develop energy use estimates of the highest possible accuracy.

\section{Cost Data}

Measure-by-measure cost data would be sought in an effort to determine the costeffectiveness of each component of the energyefficiency upgrade. Ultimately, this information could lead to an extremely precise understanding of the relationship between investment and return in terms of energy savings. This data was scheduled to be collected by PNL.

\section{Manufacturer Survey}

Manufacturers participating in the program would be surveyed by PNL to obtain initial attitudes toward energy conservation in general and the program in particular. This information would be used guide Bonneville staff members in designing future programs that would accommodate the unique features of the industry.

\section{Occupant Survey}

Information on occupants was sought to compare to site-built results and to guide development of the Super Good Cents marketing effort.

\section{Other Data}

Other data developed in the course of the project would be includisd in the database. This information included the individual WATTSUN runs that qualified each home, the factory check list, and the on-site check list (completed at the time of initial set-up).

\section{Off and - Creeping}

In many ways the demonstration project was off to a good start. Besides the SEO resources, the election to conduct the manufactured housing test as a component of an established Bonneville research mechanism afforded other benefits. Bonneville staff resources familiar with the demonstration process had been added to the project; besides having first-hand experience with RCDP's Cycle I, they had good communication links with SEOs and other organizations such as the Council, PNL, and the utilities. From an internal project management and staffing point of view, the endeavor was richer than it had ever been. 
Externally, too, coordination and communication had been established at enviable levels. The Manufactured Housing Work Group had helped to build the program in its present form. While it was an excellent "sounding board" and industry forum, it had also become somewhat of an activist organization. Its membership actively helped to redesign the specifications, to agree on incentive levels, and to establish the details of the test protocols that would be followed to provide definitive cost-effectiveness results. The SEOs assumed key roles as vital links between Bonneville and its needs, the specifications and their demands, individual manufacturers, some of whom faced unique and vexing problems, and home owners. Finally, the utilities were involved; although the majority of the participating Super Good Cents utilities played somewhat limited roles during the RCDP test/demonstration phase of the project, many were interested and kept themselves informed and involved in the project and would play key roles once the testing phase was ended.
Nevertheless, it was simply impossible to initiate a critical new standard and an entirely new procedure without "glitches." Training and orientation were essential; clear specifications were essential; close coordination between the SEOs and manufacturers was essential. Even so, most participating plants complained of start-up problems and timeconsuming, costly delays. The best laid plans of mice and men...

It had taken over 4 years, but with the launch of a comprehensive and "real-world" test, the region's manufactured housing industry had clearly entered the mainstream of the region's conservation efforts. It was clear to many members of the industry that the stakes for them and for everyone -- were clearer and higher than anyone might have imagined at the outset. 


\section{CHAPTER 10: A SLOW START -- Problems and Promise}

The start-up of the RCDP had proved to be time-consuming, difficult, and demanding -partly because so many people were, of necessity, involved. Besides Bonneville's program and evaluation staff, there were staffs of varying sizes for each of the four SEOs, the management and work crews of seven scattered manufacturers, outside research contractors, dealers, utilities, and the home owners who purchased the first energy-efficient homes.

From March 1988, and through the summer until early fall, the project was neither a smashing success nor a dismal failure. In fact, at different points in time, it could be judged either one or the other. At times it seemed as though the project was evolving just about the way it ought to -- at other times, it seemed that the demonstration program was proving only that energy efficiency and manufactured homes weren't a very good combination after all. Both the "wait-and-sees" and the "movers-andshakers" had occasion to indulge in "I-told-yousos" -- but never for long!

\section{Manufacturer Experience}

The PNL was on the road that spring, interviewing the initial five participating manufacturers to collect first-hand information on their experience with producing their first energy-efficient manufactured homes and to collect the data required for the costeffectiveness analysis that would come later (Lee and Harkreader 1989). Within 10 working days of the production of the first Super Good Cents/RCDP home, on-site interviews were completed with each participating plant's key decision makers. PNL planned to conduct second interviews to complete the documentation once the RCDP goal of 150 homes had been reached.

All of the information on manufacturer experience was summarized from this report

\section{CANDID...AND CONFIDENTIAL}

Like most industries, the manufactured housing industry is highly competitive. Information concerning internal structure and practices and details about costs and suppliers is jealously guarded. At the same time, insight into plant operations and reliable data concerning the actual costs of energy efficiency upgrades was critical to making an informed assessment of the potential of energy-efficient manufactured housing.

A dilemma. Manufacturers participating in the program were aware that the essential purpose of RCDP could not be served without this information. This knowledge notwithstanding, it was truly "a leap of faith" for them to supply it - as they did.

Participating manufacturers cooperated fully only after Bonneville, PNL, the SEOs, and others involved in the project provided solemn assurances that all information would be kept confidential. Most importantly, it would not be identified with any particular manufacturer. The process worked - a tributc to program participants and the industry!

(Lee and Harkreader 1989). In the first interview, problems encountered in the preliminary stages of the program were discussed. PNL also explored the manufacturers' attitudes toward a range of issues: innovations in the industry, energy efficiency, the market demand for energy efficiency, Bonneville, the RCDP effort, and any other issues the manufacturer wished to discuss. Finally, the manufacturer's organizational structure and the decision-making process were discussed.

These interviews began in March 1988, and extended as late as March 1989 - 10 days after the last manufacturer to join the program completed its first energy-efficient Super Good Cents home. As might be expected, the very first producers to join the effort reported the most frustration and were more vocal about the 
problems they encountered. In fact, their feedback was instrumental in ironing out some of the difficulties so that by the time later participants entered the program, the path was smoother and easier to follow.

Attitudes Toward RCDP - In general, the manufacturers' impressions of the concept behind the RCDP effort were very positive. This wasn't really surprising; after all, these were the manufacturers who had chosen to participate. Among the reasons for their positive attitudes, manufacturers voiced their beliefs that the program could provide:

- Benefits to the consumer by making a better product more available.

- Energy usage data to support the benefits of owning an energy-efficient manufac'sed home.

- Benefits to manufacturers from the public's association of the RCDP manufactured homes with the energy-efficient homes already created in the site-built sector.

Project Requirements - Some manufacturers, especially the ones who joined the program early, were critical of the project's requirements and its administration. Some of the comments and problems encountered were:

- Dealer training was inadequate and created problems. There were cases in which dealers had placed orders that could not possibly meet project requirements. As one manufacturer explained: "Dealers are the link to the public. They need to know the nuts and bolts of the program so they can sell the homes that meet program requirements."

- There were time delays, too much paperwork, and a lot of confusion over project and contract requirements:

- Specifications changed and homes had to be redesigned;

- There were problems in communicating project and contract requirements;
- Too many people (Bonneville, SEOs, utilities) were involved in the project and this caused delays.

The incidence of these problems and such comments declined over time. Project managers worked hard to see that these problems were mitigated; project participants learned from their experience and learned how to work together more smoothly.

- Many manufacturers encountered supply problems. Often, they could not use their stocked materials and new inventories had to be created and stored. These incidents usually involved windows and insulation and were not regarded as major problems. In one case, a supplier was unwilling to warranty heating and ventilation units installed under the design constraints of the Super Good Cents specifications.

- A number of manufacturers argued that the requirements for building Super Good Cents/ RCDP homes were too restrictive.

Comments included these:

- Bonneville wants "a utopian situation" (in regard to the energy characteristics of the demonstration homes).

- Engineering requirements are based on perfect situations, not the "real world."

- Bonneville should have monitored the energy consumption of the homes already being produced to see whether the RCDP was warranted.

- One manufacturer complained that the project requirements were too flexible, allowing manufacturers to build less than "quality" homes. The specific requirements mentioned in this regard were:

- Allowing self-storing storm windows to meet glazing requirements defeats the purpose of the window requirements. (According to the manufacturer, people did not like self-storing storm windows and the first thing customers would do is remove them.)

- Allowing blown-in insulation reduces the quality of the home; this type of insulation shifts and compresses during transport, reducing its effectiveness. 
- Allowing manufacturers to use paint and ceiling cover to meet vapor barrier requirements is too lax.

- Two manufacturers felt that smaller homes were especially penalized by the project's glazing requirements because the ratio of glazing to floor area was "unrealistic." They pointed out that customers like windows and suggested that the performance requirements should be based on the home's overall energy use.

- Early on, the Super Good Cents advertising was lacking. This support was deemed important by most of the participants. Again, this seemed to become less a problem as time went on.

- Manufacturers consistently praised their experiences with the SEOs. Staff members were helpful in answering questions and getting initial designs approved -- according to manufacturers, SEOs provided good administrative and technical support.

\section{SGC/RCDP MANUFACTURED HOME SALES (MONTHLY)}

\begin{tabular}{rcc} 
Month & Sales & Cumulative Sales \\
\cline { 2 - 3 } $3 / 88$ & 1 & 1 \\
$4 / 88$ & 4 & 5 \\
$5 / 88$ & 0 & 5 \\
$6 / 88$ & 2 & 7 \\
$7 / 88$ & 19 & 26 \\
$8 / 88$ & 12 & 38 \\
$9 / 88$ & 11 & 49 \\
$10 / 88$ & 8 & 57 \\
$11 / 88$ & 19 & 76 \\
$12 / 88$ & 12 & 88 \\
$1 / 89$ & 15 & 103 \\
$2 / 89$ & 30 & 133 \\
$3 / 89$ & 17 & 150
\end{tabular}

The market for manufactured homes in the Pacific Northwest covers a broad spectrum -from "low-end" to "high-end" consumers. To reach as many of these customers as possible, most manufacturers offer a range of products and options. Even so, individual manufacturers tend to become specialized, serving only a portion of the market. Tending to view marketing issues from the perspective of their particular "niche," the high-end manufacturers generally believed their customers were more energy conscious. The manufacturers selling homes in the low- to mid-price range stated that their customers were more likely to spend less money on energy options and more on other features of the home (Lee and Harkreader 1989).

\section{Dealer Experience}

A total of $\mathbf{4 0}$ dealers participated in the initial RCDP test and were surveyed following completion of the RCDP (Onisko 1989). Dealers were important in two areas: marketing and set-up. Participation by manufacturers did not automatically ensure that dealers would participate; in general, dealers function as independent agents. They are not owned or controlled by manufacturers and, in many cases, they market homes from more than one producer. Accordingly, it was important at the outset to establish contact with dealers, to provide adequate training, and to forge links between dealers and other components of the program, i.e., utilities, manufacturers, SEOs.

In the marketing area, when dealers were queried about the difficulty of selling Super Good Cents/RCDP homes they reported mixed experiences. About one-third of them found the homes "somewhat difficult" to sell, another one-third found them "somewhat easy" to market, and one-third reported that Super Good Cents/RCDP homes were "very easy" to sell. Interestingly, those dealers who reported that homes were easiest to sell also placed significantly more emphasis on television marketing support.

Based on the manufacturers' comments, there were perceived deficiencies in dealer training. In terms of timing, dealer training may have somewhat lagged the rest of the program, based on informal recollections of 
RCDP program managers. If so, this would partially account for the initial sales sluggishness. The survey was taken after the fact and sheds no light on this factor as a possible sales deterrent.

Another possible factor reported by dealers was the heavy administrative burden the RCDP program placed on them (Onisko 1989). Besides straining the dealers, program requirements seem to have altered the traditional dealer/manufacturer relationships. The program forced manufacturers to rely more heavily on dealers for accurate specifications, specific site data, and proper set-up.

Conversely, dealers were more closely linked to manufacturers because they were, in effect, selling a new product. Manufacturer support was the only marketing factor that was universally perceived as important by dealers responding to the dealer survey conducted in May and June of 1989 (Onisko 1989).

Bonneville relied heavily on its use of manufacturer incentives to stimulate demand. This effort was buttressed by Super Good Cents advertising but little else was done to build a seliing program, or even the framework for one. Once the program started, it became clear that dealers had a pivotal role in building customer demand -- as PNL had pointed out in its first report -- and plans were drawn for increased dealer training, incentives, and recognition.

\section{Consumer Response}

The first few months of the demonstration were tense. It looked as though RCDP was "all dressed up with no place to go." In a program that required both technical and marketing support, it appeared that the weak link during the first few months of the effort was going to be the marketing component, based on sales performance. By the end of April 1988, five manufacturers had proved that the Super Good Cents homes could be built. To be sure, they had problems as indicated in the PNL interviews cited earlier in this chapter, but none of the initial difficulties seemed insurmountable. Somehow the physical, technical issues were being resolved and energy-efficient manufactured homes were up for grabs!

But very few customers -- in fact, none -were "grabbing." One problem, of course, was that start-up problems had pushed the selling effort late into the spring. While everyone knows that winter will rage again, it was surely more difficult tc interest consumers in energy efficiency just as daffodils were coming into bloom and heating systems all over the Northwest were being shut down for the summer. Also, as manufacturers had indicated, Super Good Cents advertising was limited and this, too, was largely a matter of timing. Typically, the heaviest Super Good Cents advertising schedules were run during the early fall when people do think about antifreeze and heating systems and heating bills, and, so perhaps, energy efficiency. In marketing terms, this issue was the important and elementary factor of seasonality, and on this score RCDP revealed some disturbing limitations.

\footnotetext{
"The manufacturers have demonstrated that energy-efficient homes can be produced but this new technology will do little good if there is not a demand for it. Since the manufactured housing industry is competitive and sensitive to market demand, future efforts to transfer energy-related technologies should be targeted toward the retail dealers and the customers." PNL case study of the regional manufacturers' participation in the manufactured housing RCDP (Lee and Harkreader 1989).
}

In general, marketing factors were not strongly emphasized. For example, the initial consumer response to the program was never studied. Even though one stated RCDP objective for all innovations studied is to gather 
facts on marketability, the program had, in fact, developed no consistent methodology for assessing marketability in either site-built or manufactured housing programs. Neither RCDP nor Super Good Cents focused much effort on the true end user, the home owner. Of all the reports generated by the RCDP, none of them are focused on marketability, on consumer response to promotion effort, or on occupant satisfaction. Any concern with occupants was limited to technical and behavioral concerns, i.e., the thermostat set points, etc.

Apparently Bonneville had not approached the RCDP effort as a marketing challenge. There is no evidence of a marketing plan and program to support and build Super Good Cents sales and no marketing contingency plans. Not surprisingly, therefore, Bonneville had no tools available when RCDP simply went dead in the water in May and June of 1988. Fortunately, the Work Group provided a forum in which the problem could be aired and -- eventually -solved by mutual efforts. The manufacturers and dealers participating in the Work Group did deal with the rough and tumble world of selling products and did have enough of a retail marketing orientation to recognize and deal with the problem.

\section{The Industry Responds}

The timing alone made the sales challenge more demanding, but there were also other factors. For example, the new relationship between manufacturers and dealers made it difficult to determine who was calling the shots. Were manufacturers going to push the energyefficient homes down the pipeline or were dealers going to create a ground swell of market demand and pull the Super Good Cents homes through the system? With their traditional affiliations somewhat blurred, it wasn't clear for a time just where the stimulus would originate.

From the industry's traditional point of view and marketing practice, there were new players in the game as well. To get the first home launched, Bonneville and the SEOs had been heavily and closely involved in getting the home sold, its specifications determined, and its eligibility qualified. Once that home had blazed the way, Bonneville's attention and interest focused on the next manufacturer, not the next sale. However, from the point of view of the dealer and manufacturer who had just sold their first Super Good Cents/RCDP home, there must have been a vacuum as they were suddenly "left to their own devices."

The effects of the initial uncertainties were painfully evident in the monthly sales of manufactured homes (see Box - SGC/RCDP Manufactured Home Sales). Absolutely no Super Good Cents homes were sold in May and only two were sold in June. A Work Group meeting, held during this period in June 1988, discussed the problems and probably helped to clear the air. ${ }^{1}$

While Bonneville had provided the support required to sell the first Super Good Cents/ RCDP home for a particular plant, to launch the process and bring the individual manufacturer and dealer on board, it became clear in June that Bonneville had no consistent long-term marketing plan. Bonneville was not planning to push 150 homes through the pipeline home by home. The June Work Group meeting revealed, more by inference than design, that dealers and manufacturers were going to have to deal with the marketing issues, use the tools provided, take advantage of the incentives, and create a demand for energy efficiency -- even in the summer.

The participants rose to this challenge. One strong suggestion from the Work Group was that Bonneville alter its contract requirements so that homes could be built "on spec." This meant allowing manufacturers to build energyefficient homes for dealers to site on their lot so that home buyers could see what a Super Good Cents manufactured home was all about. The dealer and manufacturer participants convinced Bonneville that without such a tool, it would be 
difficult to motivate buyers to make a major purchase at a premium price, in spite of the incentive. This made sense and Bonneville agreed to the premise, taking steps to provide the appropriate cash incentives even though the "spec-built" home was not, strictly speaking, eligible under the terms of the Super Good Cents/RCDP contract.

Besides working out such details, the Work Group meetings and one-on-one contacts throughout the early summer of 1988 seemed to work. Additional sales of Super Good Cents/ RCDP manufactured homes were made, and after its initial 3-month flirtation with disaster the project began to move and develop a momentum that, although at times not substantial, it never again lost. Marketing, it became clear, was an industry challenge and once this was established, sales were generated.

A strong factor that undoubtedly helped to increase the sales of Super Good Cents/RCDP homes was the innate competitiveness of the industry. As more manufacturers joined the program, it became clear that some individual firms were more intent on aggressive sales of energy-efficient homes than others. For a variety of reasons, certain manufacturers had long been more supportive than others; now some of them were moving far ahead of others in stimulating demand and generating "realworld" orders. These innovators not only proved that there was a market for Super Good Cents homes, their mere success was strong motivation because of the close-knit rivalry that distinguished the industry.

Bonneville's lack of marketing leadership or initiative during this early crisis and its willingness to defer the problem to manufacturers and dealers may have had longterm consequences. As events unfolded, the industry appeared to doubt the ability of Bonneville, the SEOs, or the Council to recognize and treat the marketing issues involved in the shift to energy-efficient manufactured homes (and pricing). As the region moved to change public attitudes toward energy efficiency and/or building a franchise for upgraded homes, the industry consistently raised the issue of marketability.

In spite of its substantial investment in marketing Super Good Cents to regional consumers, Bonneville seems to have learned little from the experience. It could not provide strong marketing leadership or direction. In 1988, the agency had no perspective on the problem and no mechanisms to provide sophisticated marketing support during those first crucial months of the RCDP. It was a lesson not lost on the industry and not one ever forgotten. Over the next few years, the industry would consistently challenge Bonneville's marketing assumptions and jealously guard its hard-won niche in the Pacific Northwest's housing market.

\section{SEO Experience}

The SEOs of the four states comprising the Pacific Northwest region had worked with Bonneville on research and demonstration matters since RCDP Cycle I in 1985.

Reporting methods, channels of communication, and coordination had all been ironed out over nearly 3 years of shared experience.

Nevertheless, the addition of the manufactured housing test as an innovation to be tested in RCDP's Cycle II had tested their mettle (BPA 1988a).

In terms of scale, the manufactured housing innovation dwarfed the other contemporary efforts. Despite the magnitude, complexity, and importance of the project, there had been little time to prepare; the decision to include manufactured housing in RCDP came at the eleventh hour. There were budget matters, organizational issues, and questions concerning the likely participation by manufacturers to resolve. When these were settled, in the fall of 1987, the SEOs had less than 4 months to marshall their forces and get up to speed.

SEOs established liaison with the manufacturers, the IPIAs and the utilicies. 
They also finalized the process they would use to qualify homes for RCDP participation (and incentives). In fact, as indicated by the manufacturers in PNL's case study (Lee and Harkreader 1989), SEOs were particularly successful in this aspect of their responsibilities.

As part of the process that would be used to qualify homes for participation in the RCDP (and for the incentive payment), Washington SEO made the changes in the WATTSUN program normally used to qualify Super Good Cents homes. These changes were required to adapt WATTSUN so it could be used to qualify manufactured homes under the revised specifications developed by the task group during the summer of 1987.2

Under the terms of its master contract with Bonneville, Washington SEO ensured that other SEOs were also competent to qualify Super Good Cents/RCDP homes. As a practical matter, this involved only the Oregon Department of Energy (ODOE). There were no manufacturers in Montana and, in spite of strong effort by the Idaho Department of Water Resources, Bonneville, and others, no Idaho manufacturers joined the RCDP effort during the test period.

Bonneville and the SEOs were aware that dealers were "the weak link in the chain," from both technical and marketing points of view. ${ }^{3}$ Even as late as October 1988, the Washington SEO reported that only a few dealer set-up crews were familiar with the program. At this same time, 8 months into the RCDP effort, only 23 dealers in the region were participating in the program; most of these (19) were in Washington State.

Budget constraints were an issue but Bonneville's program managers agreed that training was critical. Modifications to the Washington SEO contract were initiated to provide more dealer training. The type of effort was also called into question; the ODOE recommended that more flexible, more specifically targeted, one-on-one training could better solve the types of problems being encountered. It was difticult to schedule training sessions and coordinate the activities of a group as diverse as the dealers proved to be. ${ }^{3}$

A proposal advanced by the SEOs relatively late in the demonstration effort called for providing recogni' ion for dealers and coupling this with a dealer incentive program. Such a marketing effort, fairly common in many retail sales programs, was recommended as a possible means of overcoming dealer resistance and inertia. Unfortunately, the restrictions placed on Bonneville as a federal agency severely limited its ability to provide such typical retailer incentives as travel prizes. Anything Bonneville could legally provide would have to involve attendance at pertinent business conferences or attendance at "essential meetings. "3 Hardly a way to build dealer enthusiasm for Super Good Cents/RCDP selling programs.

A significant amount of SEO attention and time was involved with issues related to data collection and database management. Throughout the RCDP period, Bonneville's primary concerns were focused on its information needs -- Bonneville never forgot its objective was to demonstrate regional costeffectiveness of the recommended specifications designed to bring manufactured homes to MCS levels of energy efficiency. To better manage and coordinate data issues, Bonneville would shortly set up a committee to permit these matters to be handled more directly and more efficiently by a smaller, more knowledgeable group (see below and Chapter 11).

\section{Utilities}

Not all utilities participated actively in the RCDP, but those operating in the region's most populated, fastest growing areas along the north-south interstate highway -- the I-5 Corridor through Seattle and Portland-- had long been concerned about manufactured housing and its impacts on load growth. These same utilities were generally in the forefront of 
supported the Super Good Cents program for site-built homes (BPA 1989b). In the site-built sector, their roles were more straightforward and more central. Utilities ran the WATTSUN program to qualify Super Good Cents homes in the design stage, verified their proper construction, and paid the incentive to the contractor or home owner (based on the sales contract between contractor and home owner).

In manufactured housing, such an arrangement would not have been workable Because any manufacturer could potentially site a home anywhere in the region, the plant could, in thecry, be overrun with utility inspectors from four states. From the utilities' point of view, they would, in theory, have to cover 17 manufacturing plants in four states. This, of course, was the basis for the decision to have the SEOs qualify the Super Good Cents/RCDP homes.

Although that solved problems, it also created them. The introduction of the SEOs into the Super Good Cents process required adjustments on the part of utilities -- now utilities were not in control of their time, their schedules, or the quality of the home being certified. Like everyone else involved in the RCDP experience, utilities were being asked to compromise, to work in a new and different manner. For the most part, they rose to the occasion.

The utilities emerged as key factors in dealer orientation and some of them developed extremely good relationships with dealers in their area -- SEOs were often instrumental in bringing utilities and dealers in a particular area together. The utilities were also responsible, in areas where Super Good Cents was being run by the local utility, for the final on-site inspection of the manufactured home once it had been shipped from the factory. Utilities became the "experts" on set-up specifications and many of them worked effectively with dealers to improve set-up procedures. Often, utilities played important roles with home owners as well, in some cases helping dealers to resolve customer complaints and deal with home owners' questions.

\section{Mid-Course}

On November 3, 1988, the Manufactured Housing Work Group met once again to review progress and discuss next steps." As of the meeting date, 61 RCDP homes had been sold, chiefly in climate zones 1 and 2 in Washington and Oregon. By this time, however, homes had been sold for siting in Idaho and the first home slated for climate zone 3, in Missoula, in cold, cold Montana, had just been sold by an Oregon manufacturer.

Sales seemed to be picking up and one of the manufacturers observed that "people don't think about insulation in July, they think about insulation in October." By now, the problems discussed earlier had been thoroughly aired -seasonality was indeed a factor. More effort had been put into dealer training and SEOs worked hard to bring dealers and utilities together. Although dealer response to training was not as enthusiastic as the SEOs had hoped, the feedback from manufacturers present at the meeting was that the training had been effective. It was their observation that some dealers were simply more responsive, more competitive, more innovative than others.

Marketing efforts were working and the homes were being sold. By now, five "specbuilt" houses had been authorized and the results clearly justified the effort. Just as the manufacturers had predicted, these "demonstrators" were helping dispel some of the doubts about Super Good Cents manufactured homes. Some more novel market pressures were being felt. Through dealers, manufacturers were astonished at being encouraged (and prodded) by utilities."

This new liaison between manufacturers and utilities was a strange outgrowth of the RCDP. At least at the outset, it was not always comfortable and, at times the industries were at loggerheads (see Box - Minimum Shell 


\section{MINIMUM SHELL REQUIREMENTS}

Even though the SGC specifications for manufactured homes allowed homes to qualify when the added efficiency of a heat pump was calculated into an energy budget, an 1-5 utility had refused to certify one such home as Super Good Cents. The utility maintained that minimura shell (insulation and glazing) requirements must also be met. For a time feelings ran high. Manufacturers felt they had complied with requirements while the utility felt that it had the right - if not the obligation - to require that all SGC homes be built to minimum standards of energy efficiency. and not rely solely on heat pump efficiency to qualify inefficient designs.

loggerheads (see Box - Minimum Shell Requirements). The Work Group played an important role as a forum (and sometimes an arena) for the two industries to determine their goals, resolve their differences, and work together to achieve the many common objectives these interchanges uncovered. In the course of the RCDP, the lowering of barriers between utilities and manufacturers was increasingly evident.

\section{Air Leakage Tests}

The Work Group had also evolved as a kind of scientific forum, a "real-world" symposium, in which the research efforts underway were reported. In many cases, these were of great interest to the industry, providing insight into manufactured housing characteristics versus the site-built market and/or within the industry. For example, at the November 3, 1988, meeting a major study of the air leakage characteristics of manufactured housing was presented (Ek et al. 1988). By this time, extensive test experience from a variety of sources had been collected; the results of this testing were becoming more important as the sample was growing larger and larger. The report covered 93 double-wide homes produced by 19 different manufacturers (52\% of the homes tested were produced by five manufacturers).
As shown in Table 10.1, average leakage rates for double-wide manufactured homes were found to be $8.40 \mathrm{ACH}$ at 50 pascals $(\mathrm{Pa})$ pressure differential. Using a model, these results were predicted to be approximately 0.50 $\mathrm{ACH}$ under natural atmospheric conditions. This suggested that manufactured homes in the Pacific Northwest performed moderately better than site-built homes using current residential construction techniques and practices. According to the report, the air leakage rates for new site-built homes were approximately 10 $\mathrm{ACH}$ at $50 \mathrm{~Pa}$ (Nagda et al. 1985).

In addition to collecting the data from blower door testing, investigators explored the causes of air leakage. Using a smoke-stick (which reveals air flow patterns by creating a visible haze), the researchers determined that the major contributors to leakage in manufactured homes were the marriage lines between the homes' sections, the heating system cross-over ducting, plumbing holes, windows, gaps around shower or bath units, and the area around the electrical panel. Although glazing area was recorded for about $\mathbf{5 0}$ homes, no meaningful correlation vetween glass area and leakage rates was found.

\section{Other Data Issues}

Just the day before the November Work Group meeting, Bonneville had initiated a new body, called the Data Management Committee (DMC), to manage data issues. Much of the agenda of the Work Group meeting was devoted to describing this group and reporting the types of issues with which it was dealing. The DMC was an important development in this chronicle and deserves its own chapter, Chapter 11, where it can be described in detail. The rest of the November 3,1988, Work Group meeting will be discussed in Chapter 12 -- it was a pivotal event marking the end of the beginning, the beginning of the end of the RCDP experiment. 
TABLE 10.1 - Manufactured Housing Air Leakage Performance (93 double-wide homes)

\begin{tabular}{||l|c|c|c|}
\hline & $\begin{array}{c}\text { Specific } \\
\text { Leakage Area }\end{array}$ & $\begin{array}{c}\text { Air Changes } \\
\text { per Hour at 50 Pa }\end{array}$ & $\begin{array}{c}\text { Natural Air } \\
\text { Change Rate }\end{array}$ \\
\hline Average & $2.70 \mathrm{~cm}^{2} / \mathrm{m}^{2}$ & 8.38 & 0.50 \\
\hline Sample Std. Deviation & 0.68 & 1.93 & 0.15 \\
\hline Coefficient of Variation & 0.25 & 0.23 & 0.29 \\
\hline
\end{tabular}

(a) Effective leakage area $\left(\mathrm{cm}^{2}\right)$ per square meter of building envelope area, as determined from the calculated flow rate $10 \mathrm{~Pa}$.

(b) As determined using the Lawrence Berkeley Laboratories model, based on flow rate at $4 \mathrm{~Pa}$.

Source: Ek ot al. 1988

A slow start indeed. But the beginnings of RCDP were not without their merit; valuable lessons had been learned. More important, the issues had been acted upon. And, even more important than that, they had not been acted upon unilaterally by Bonneville. Rather, more indirect -- sometimes slower, sometimes more

\section{End Notes}

1 The scant documentation of this Work Group meeting, held on June 6, 1988, consists only of an agenda and hand-written notes.

2 Letter from the Chairperson (Bonneville Program Manager) to the RCDP Manufactured Housing Task Group. August 19, 1987. Bonneville Power Administration, Portland, Oregon. painful -- solutions had been found by a new and somewhat unlikely coalition. Manufacturers, dealers, utilities, SEOs, trade associations, researchers, and even writers were working together to create solutions and bonds strong enough to withstand even greater challenges in the future.
3 Internal report on the October 21,1988 , RCDP Manufactured Housing Meeting prepared November 18, 1988, by the Bonneville Power Administration, Portland, Oregon.

4 Internal report on the November 3, 1988, Manufactured Housing Work Group Meeting prepared November 30,1988 , by the Bonneville Power Administration, Portland, Oregon. 


\section{CHAPTER 11: ENTER THE DMC -- BPA Continues/Expands Group Activity}

The detail involved in the research aspects of the RCDP was immense; the number of steps and the coordination required was challenging. To apportion the tasks, help coordinate them, and continue the cooperative, informationsharing, teamwork-oriented environment that had been fostered, Bonneville established another work group, the Data Management Committee (DMC), in the fall of 1988. ${ }^{1.2}$ DMC meetings were held in Portland; the timing of these events was based on workload, availability of key data and reports, and the schedules of the principal participants in the process. To help minimize misunderstanding and advance the project, reports of all DMC meetings were circulated soon after each of these meetings.

Initially the attention of the DMC was focused on data collection and later, as raw data was collected, the establishment of agreed-upon data management guidelines. As data requirements were completed and the RCDP reached its goal of 150 sited manufactured homes, the DMC oversaw the analysis of available data and, finally, the preparation of RCDP reports. Increasingly, as the project matured, it became clear that the DMC was becoming a resource in itself. It was the repository of a great deal of technical information -- much of which was at once original, reliable, and potentially useful not simply to the RCDP but to others.

Gradually, therefore, the role of the DMC expanded to include technical issues beyond data and audiences beyond the RCDP participants (already large enough by any standard). In recognition of the expansion of its role and its audience, the DMC eventually changed its name and its charter. The group changed its name to the Manufactured Housing Technical Advisory Group (MHTAG) on September 6, 1990, nearly 2 years after its inception. ${ }^{3}$ The change in name clearly reflected the change and expansion in the group's function over time:

Manufactured Housing Signalled that the group had expanded its outreach from the RCDP and the regional work group and now encompassed the entire industry.

Technical Advisory Group Indicated that the group would no longer be limited to dealing only with data issues (in fact, the group had long dealt with broader technical issues that applied to Super Good Cents/RCDP) but would deal with a broader spectrum of technological matters.

\section{Genesis}

Such developments were beyond the expectations of the RCDP managers who conceived the idea of the DMC, arother experiment in group dynamics. The origins of the idea can be traced along two lines of development. The first, and major influence, was the work group experience. Since 1986, nearly 2 years earlier, the manufactured housing project had made excellent use of the public process, achieving new levels of regional teamwork. Not only did the work group serve as a sounding board, it had moved well beyond its original purpose and somewhat passive goals to become a key factor in launching and advancing the demonstration project. The work group had been instrumental in

- driving the project to a regional test

- securing funding for the project in a period of retrenchment

- taking advantage of existing programs, experience, and resources by urging that the project be administered as an RCDP effort 
- ensuring broad-scale industry participation and interest in the project

- solving problems -- particularly marketing challenges -- as they arose in the course of the project.

Small wonder, then, that the project's managers, as they laid out the research plans, thought in terms of some type of group participation. In fact, the work group was already functioning as a symposium for technical reports and discussion of technical issues. It was therefore a straight-forward, logical development to make the work group a forum for data issues even earlier in the process -- even before the data was collected.

\section{DMC MEETING SCHEDULE} (1988-1990)

November 2, 1988

December 7, 1988

January 23, 1989

March 29, 1989

May 5, 1989

June 14, 1989

July 20, 1989

September 12, 1989

October 25, 1989

January 11, 1990

February 13, 1990

April 12, 1990

June 27, 1990

August 2, 1990

September 6, 1990

(At the September 6, 1990, meeting the group's name was changed to MHTAG; it had concluded the RCDP lasks for which it had been organized.)

The problem was that some of these issues were highly technical -- and often not very compelling even though important. It would be easy, project participants realized, to completely overwhelm the work group with picky details such as what type of computer program to use for database storage or how to assign identification codes to RCDP homes. These issues did have to be resolved; they probably did not require $\mathbf{4 0}$ people to resolve them. Earlier, a smaller task group had successfully been formed and worked together to tailor Super Good Cents specifications to manufactured housing applications and capabilities and this was a model for a similar task group to deal with data issues.

The idea that data management could become a time-consuming problem for the work group was confirmed by RCDP experience with data issues that had arisen on other projects -this was the primary impetus for the second line of development leading to the idea of setting up the DMC. The idea of a small but diverse team to deal with data issues was being explored for all RCDP projects as a result of the experience of the SEO and Bonneville managers who had worked together previously, during RCDP Cycle I. This experience had made them aware of the ease with which a research project's data management could go awry, demand time, and compromise a research effort.

The thought was that the DMC would extend the group process into more technical details. However, because it would be a smaller group, composed of members with technical expertise and interest, it could deal with such issues more quickly and more competently than a larger, more diverse group. At the same time, the sense of participation would not be lost -membership on the DMC was always open to anyone who wanted to participate; meetings were always open to any work group members who wanted to attend.

\section{The First DMC Meeting}

The first DMC meeting was held on November 2, 1988, at Bonneville Headquarters in Portland, Oregon. It was attended by technical representatives of the Washington SEO, the Oregon DOE, the Council, PNL, Bonneville management, and a Bonneville data management contractor, as well as a manufactured housing trade association 
representative and a writer who began to develop comprehensive meeting reports. ${ }^{2}$

\section{DMC POLICY GUIDELINES}

The RCDP Manufactured Housing Data Management Committee (DMC) has been formed to advise and review the manufactured housing data collection process.

The Data Management Committee shall assist in

1. The development of procedures to design, collect, verify, document and analyze all manufactured housing data collected under RCDP.

2. The development of guidelines to:

(a) Protect the confidentiality of all data collected from various participants.

(b) Disseminate all information and ensure its appropriate use.

(c) Review publications which use data collected under the RCDP.

3. The evaluation of all requests for alternative or added research objectives.

Much of the attention of the participants in this initial meeting was focused on the project's data needs (see below). Relatively late in the process, the group discussed the policy guidelines that had been proposed for the new group. The proposed guidelines stressed Bonneville's role and DMC members were concerned that the committee could be viewed as simply a vehicle for project management. This was distinctly not the case; the overriding purpose of the DMC was to ensure that the research being conducted met the region's needs and that it would be useful and accessible to the region. As one member described it: "We're putting the data candle on a lamppost and not under a bushel." 2 The policy guidelines, as developed, reflected this more general approach (see Box - DMC Policy Guidelines).

Because the database was going to be large, Bonneville had proposed that an expert database manager -- one of Bonneville's outside contractors -- be a member of the committee.
During the meeting, the overall data management approach and the capabilities of the Residential Data Acquisition System (RDAS) that would be used to manage the data were explained for the group; this introduction helped participants to understand some of the data collection requirements. The RDAS was one of the most straightforward, simplest, and flexible data management systems available -information could be recalled quickly and the system would accept input data in a range of formats. There were highly technical issues to discuss at the DMC's first meeting but, in essence, the intent was that the manufactured housing demonstration project would make maximum use of lessons learned from RCDP's Cycle I and conform to Bonneville's state-ofthe-art in database management.

\section{Data Collection Requirements}

To provide background and help establish the group's working parameters, the going-in research objectives of the RCDP project were outlined and discussed. By reviewing the objectives, DMC members could better understand the project's data needs and its current data collection efforts. At this point, during the first year of the project, data collection was the chief concern and priority. The most immediate goal for the DMC was to establish and coordinate RCDP's data collection requirements, establishing a consensus about how data would be collected and the questions the information was intended to answer:

Cost Data - To determine measure-by-measure cost-effectiveness and provide guidelines for incentive levels, PNL was charged with collecting cost data for: (1) HUD code homes, (2) current practice homes, and (3) Super Good Cents/RCDP homes built to the MCS.

Obtaining reliable cost data from the industry would be difficult; as discussed earlier, manufacturers were extremely concerned about revealing these figures to competitors.

Energy Use Data - Indoor temperatures were a tricky part of this analysis -- energy-use data 
would not be useful unless temperature, thermostat settings, and ventilation practices were known and standardized home-by-home. Home owners had a role to play beyond purchasing the home; the energy usage data was based on weekly meter readings forwarded by the home owner/occupant. The goal of this aspect of the research was to develop "realworld" energy usage of the RCDP homes to determine their energy consumption versus HUD code and current practice manufactured homes. The data would be used to

- summarize MCS energy consumption/ performance (heating and hot water)

- normalize energy heating consumption versus floor areas

- compare predicted WATTSUN run performance to actual performance.

Occupant Survey - This research would be based on a format established by earlier RCDP surveys of the occupants of site-built homes. It would permit factoring quality issues, i.e., occupant satisfaction, into the final analysis.

Manufacturer Survey - PNL was responsible for data collection for its case study of the attitudes and experience of the manufacturers participating in the RCDP.

Infiltration Testing - Manufactured home infiltration testing was to be integrated with an infiltration testing protocol being developed for all other RCDP site-built testing. The goal was to base infiltration testing on a single protocol that would apply to both manufactured and sitebuilt homes procedures and results. This protocol was both the basis and the outgrowth of a series of studies called the Northwest Residential Infiltration Survey -- the NORIS protocol. One of the timing problems with the project was that the NORIS protocol was being revised. Waiting until the protocol was finalized could delay getting into the field to check on infiltration conditions in the RCDP homes.
The Baseline - A problem almost from the start - and one which was to plague the project until the end -- concerned the baseline, i.e., the "current practice" against which the energy performance of the test homes would be compared. The Washington SEO was charged with developing a 30-home sample of "basecase" manufactured homes. These were homes typical of those sold in the region but without the energy-saving features called for by the Super Good Cents specifications. However, the selection, the role, the characteristics -- even the nomenclature -- of these homes was uncertain. At various times, they were called control homes, current practice homes, or baseline homes.

The homes were not, technically, any of these. They would not be used as controls or to establish a baseline. In fact, a computer program called the Princeton Scorekeeping Method (PRISM) (Fels 1986), being used by Bonneville to evaluate site-built home performance, would be used to make these comparisons. The collected data from the $\mathbf{3 0}$ control homes proposed as part of RCDP would be used only to help calibrate PRISM to the manufactured home environment. PRISM would compare the billing data from these homes with the Super Good Cents/RCDP homes and approximately 300 homes with billing history data. ${ }^{1}$ It was agreed that the larger 300-home sample should be called comparison homes to avoid confusion. ${ }^{2}$

The issue was discussed at length at the first DMC meeting. Bonneville's Evaluation Branch believed the proposed 30-home sample would provide a broad enough range of current practice manufactured homes to permit analysts to make any necessary adjustments to PRISM, but several thorny issues emerged. ${ }^{2}$

- Manufacturers building the Super Good Cents/RCDP homes did not represent the entire industry. RCDP participants tended to cluster at the "high-end" and the "lowend" of the market so obtaining data on 30 homes coming off their lines in 1988 (as 
proposed) would not represent the current practice of the industry as represented by the 300-home comparison home sample.

- The $\mathbf{3 0}$ homes would not represent the same point in time, either, because the comparison homes were built somewhat earlier (1987 and 1988). Ideally, the control homes should be selected as a sub-sample of the 300 comparison homes to which PRISM was being calibrated.

- Many sources of potential bias in the way the homes were selected or measured were cited and discussed: concentration of comparison homes in parks because these were easier to canvass, confining the comparison home sample to double-wide homes, unusual buyer selection criteria affecting the control homes selected, skewing of the sample because the manufacturer producing the most homes would be over-represented, etc.

Before the RCDP would run its course, this issue was to recur; it was troublesome and confusing from the start. Eventually, a sample of only eight control homes was obtained and, the energy-savings analysis was performed by simulating the performance of RCDP homes without their energy-saving features and not by using PRISM to establish the energy performance of a comparison home sample.

Thermal Performance - The test program's slow start meant that 150 homes could not be sold and sited prior to the end of the 1988-89 heating season. It appeared that the home owner monitoring and the scheduled ventilation testing required to assess thermal performance would present problems: (a) In some cases there would be 2 years of home-owner data covering the 1988-1989 heating season and the 1989-1990 heating season. (b) Because of the expense of getting people into the field, ventilation testing would be delayed until after all 150 homes were sited, placing time and scheduling pressure on this aspect of field research effort.
Forms and Contracts - One of the functions of the DMC was to coordinate all the various forms (e.g., case studies, occupant surveys, dealer surveys, home owner postcard data forms, in-plant and dealer check lists, etc.) required to administer the test program. A secondary purpose of this coordination effort was to design forms to facilitate the entry of vital information into the RDAS database.

\section{The DMC Over Time}

Initially, the DMC met for a full day on November 2, 1988, in an exhausting and lengthy meeting that set the tone and the agenda for many more meetings to follow. The group continued to meet regularly throughout the RCDP test and evaluation period. Functioning as a forum, a clearinghouse, and a peer review mechanism, the group met regularly during most of the next 2 years (see Box - DMC Meeting Schedule). In the process, the DMC acquired more and more shared and unique knowledge as the RCDP test of the manufactured homes program matured.

\begin{tabular}{|ll|} 
& \\
& DMC STUDY ITEMS \\
DMC\#1 - & Manufacturers Cost Data \\
DMC\#2 - & Energy Use Data \\
DMC\#3 - & Manufacturers' Survey \\
DMC\#4 - & Infiltration Study \\
DMC\#5 - & Occupant Survey \\
DMCH6 - & Design Check List \\
DMCH7 - & In-Plant Check List \\
DMC\#8 - & Set-Up Check List \\
DMC\#9 - & Dealer Costs \\
DMC\#10 - & Bascline (Control) Homes \\
DMC\#11 - & Control (Comparison) Homes \\
DMC\#12 - & Dealer Exit Survey \\
& \\
& \\
\hline
\end{tabular}

At its second meeting, on December 7 , 1988 , the DMC dealt in detail with issues such as the 12 "study items" (see Box) that constituted the research planned for the project and the design of forms so that the data gathered would be useful and consistent. ${ }^{4}$ 
Other issues included timing, data quality control, and potential use and usefulness of RCDP data in the development of a new, upgraded HUD code. (A review of the Federal Manufactured Housing Construction and Safety Standard had been underway at HUD for some time and PNL was under contract to HUD to assist in developing a new standard.) The only item that presented any difficulty during this meeting was continuing concern and confusion over the issue of control homes."

Early Issues - As 1989 began, preliminary cost data was available and the DMC discussed the shortcomings and problems this information suggested. The group also reviewed the need for a comprehensive analysis plan, explaining how the individual study items would be used and how they related to one another.'

Control Homes -- Unresolved - Events somewhat overtook the DMC's schedule in early 1989 as the volume and momentum of Super Good Cents/RCDP sales rose suddenly. By early spring 1989, the RCDP target of 150 homes had been sold. As it turned out, the DMC did not have much time to exert any substantial influence on the way this phase of the RCDP was being run. One of the consequences of this relatively rapid turn of events was that the Washington SEO was unable to develop a successful effort to recruit the 30 control homes as originally planned. There were funding and contracting difficulties and by the time these were straightened out, the RCDP phase of the project was complete. ${ }^{6}$

The Need For Improved Cost Data - Another thorny issue was the cost data being collected by PNL. The DMC had helped develop the collection protocol and was directly involved with the type and quality of the data that PNL had been able to obtain with this approach. The technique was yielding cost estimates that the DMC found "unreliable" and "inconsistent." It appeared that the costs manufacturers were providing to PNL were the prices that manufacturers were charging for the upgrades. This was a concern for two key reasons:

- Because the costs being provided were actually prices, these figures were marketdriven and not reflective of the true cost of the upgrades.

- Methodologies used by different manufacturers to determine pricing varied so that the cost data was not comparable across the industry.

The DMC urged that these concerns be aired with the work group and that manufacturer cooperation to help obtain more relevant cost figures be solicited at a work group meeting scheduled for the next day. Another approach suggested was to have the SEO representative accompany PNL to the interviews and deal with each manufacturer on as intimate a basis as possible to encourage fuller disclosure of costs and the manufacturer's methodologies.

The Manufactured Housing Institute - HUD's development work to study possible new standards for the Federal Manufactured Housing Construction and Safety Standard had led the industry's chief trade association, the MHI, to form a consensus committee to examine the issues and make recommendations to HUD on proposed new construction and safety standards. ${ }^{7}$ MHI's involvement, actions, and recommendations were of great interest to the members of the DMC. The DMC (and later the MHTAG) would follow these developments over the next 3 years for two overriding reasons:

- The cost and thermal performance data that were beginning to be collected on the RCDP certainly represented the most recent and the most accurate (even if less than optimal) information avaiiable on manufactured homes. The DMC felt strongly that this information should be considered by the MHI at the outset. 
- Any action ultimately taken by HUD that altered current standards would affect the "gap" between current practice and the MCS; this, in turn, affected costeffectiveness calculations, incentive levels, degree of manufacturer participation, etc.

Planning for Infiltration Testing - As the DMC met during the summer of 1989 , one of its main concerns was finalizing plans for the infiltration study that would be conducted during the 19891990 heating season by PNL. ${ }^{8}$ The team discussed and reviewed the development and the timetable of the revised NORIS protocols for such measurements.

New Members - Two new members joined the DMC. In September 1989, a manufacturer's representative joined the team as a full-time member. ${ }^{9}$ The following month, a principal of Ecotope, a Seattle-based research and consulting firm, was added to the committee. Ecotope had been awarded the data analysis contract for the RCDP analyses that would be conducted once all the data were collected. ${ }^{10}$

Data Analysis Timetable - Information from the ventilation study conducted by PNL was essential to Ecotope's thermal performance analysis. Early in 1990, the DMC learned that because of delays in finalizing the NORIS protocol and the time required to ensure that the field data was checked for accuracy and reliability, this information would not be turned over to Ecotope until June 1, 1990. ${ }^{11}$ This affected the schedule for the data analysis phase of the project and delayed the first thermal analysis and cost-effectiveness reports until fall 1990.

Other Issues - The DMC was likely to take up almost any issue that presented technical or programmatic challenges and/or to share any experience of its members that was potentially helpful to the program and to others working on the project. Besides the issues highlighted in this section, the DMC worked on:
- Developing accurate and consistent U-values to assign values to the estimated heat loss characteristics of manufactured home components. U-values would change with variations in design, construction, and materials. RCDP Cycle II built on the experience and data gained from earlier RCDP tests; the DMC was concerned with the accuracy, usefulness and consistency of the U-value data used.4

- Reviewing and commenting on a dealer exit survey that was conducted by Washington SEO and summarized by Bonneville (Onisko 1989).

- Ironing out concerns over variables in the way WATTSUN runs were conducted. For example, there were differences in the way cut corners, entryways, bays, and other design features were handled. Investigation revealed that even in "worst case" situations the variations had minimal (less than 10\%) effect on predicted heat loss performance. ${ }^{5}$

- Revisions in Super Good Cents specifications that seemed to be required once the thermal performance analysis began. Ecotope's analysis provided a more detailed look at several assumptions that proved to be incorrect. For example, floor insulation was not as effective as supposed. The DMC served as a forum for discussing the issues and then as a conduit to program managers who could institute whatever changes in Super Good Cents specifications seemed clearly indicated by the analysis results as they progressed. ${ }^{12}$

- Other findings derived from the analysis in progress were reviewed, such as the performance benefits of insulating ducts and the evident difference in the effectiveness of blown-in insulation versus batt insulation which had to be "stepped" to fit into the tight attic spaces where the low-pitched roof meets the wall. ${ }^{13}$

- Discussion of a Heat Loss Reference Manual and coordinating its preparation with the expressed needs of manufacturers. Ecotope undertook the preparation of the manual to 
provide manufacturers a relatively simple means of evaluating design options. ${ }^{14}$

- Development of minimum component requirements that all Super Good Cents homes must meet regardless of the home's estimated energy performance. ${ }^{15}$

\section{A Bridge to Super Good Cents - and Beyond}

It is easy to see that, although the marketing and siting phase of RCDP had ended, the DMC continued to meet to oversee the RCDP ana'ysis efforts and these meetings expanded to include a host of expanded activities. Many of the DMC members were SEO representatives who would play roles very similar to those they had carried out in the RCDP in the broad-scale Super Good Cents program that would immediately follow the demonstration effort. These DMC members naturally continued to use the DMC as a forum for sharing experience, as a sounding board, and as a means to obtain technical advice.

As a kind of technical "brain trust," the DMC was simply a logical place to discuss many of the issues that inevitably arose. It was a busy time for technical issues -- the RCDP results suggested change, Bonneville was reviewing the Super Good Cents specifications as part of a normal review cycle, HUD was undertaking a review of the Federal Manufactured Housing Construction and Safety Standard, MHI was making recommendations to HUD. By this time, there simply was no better forum and members had learned to function as a team. DMC members were case-hardened and experienced both in the field and in the sophisticated computer simulations that had been developed to evaluate energy performance.
These opportunities to share experience and achieve technical agreements undoubtedly smoothed the transition from the RCDP demonstration and test experience to the "real world" of Super Good Cents. They also helped to discuss other issues, such as the Council's response to MHI's preliminary analyses or its recommendations to HUD regarding climate zones to be used in conjunction with any new energy standard.

It is difficult to imagine how some of these issues would have been aired, analyzed, and resolved without the DMC. Through the interchange of ideas and the dynamics of teamwork, it became a stimulating forum, performing far more extensive and flexible functions than those imagined when it was first proposed and established. Among the accomplishments of the RCDP, the establishment of a regional technical forum -which is not what was planned but what the DMC came to be -- must certainly be included.

$* * * * *$

By early 1990, the DMC was becoming a different body. It was at once an RCDP institution, helping to complete the analysis phase of the demonstration project, an Super Good Cents institution, coordinating the technical changes that were taking place in the regular Super Good Cents program as it expanded to include manufactured homes, and a regional technical advisory panel, a clearinghouse for technical issues and information for the region and for the country.

\section{End Notes}

1 Meeting minutes from the RCDP Manufactured Housing Task Force meeting on August 19, 1988, Bonneville Power Administration, Portland, Oregon.

2 Internal Report on the November 2, 1988, Manufactured Housing Data Management Committee (DMC) meeting prepared November 22, 1988, by the Bonneville Power Administration, Portland, Oregon. 
3 Internal report on the September 6, 1990, Manufactured Housing Technical Advisory Group (MHTAG) meeting prepared October 9,1990 , by the Bonneville Power Administration, Portland, Oregon.

4 Internal report on the December 7, 1988, Manufactured Housing Data Management Committee (DMC) meeting prepared December 21, 1988, by the Bonneville Power Administration. Portland, Oregon.

5 Internal report on the January 23, 1989 , Manufactured Housing Data Management Committee (DMC) meeting prepared February 11, 1989, by the Bonneville Power Administration, Portland, Oregon.

6 Internal report on the March 29, 1989, Manufactured Housing Data Management Committee (DMC) meeting prepared April 20,1989 , by the Bonneville Power Administration, Portland, Oregon.

7 Internal report on the June 14,1989 , Manufactured Housing Data Management Committee (DMC) meeting prepared June 24, 1989, by the Bonneville Power Administration, Portland, Oregon.

8 Internal report on the July 20, 1989, Manufactured Housing Data Management Committee (DMC) meeting prepared August 11,1989 , by the Bonneville Power Administration, Portland, Oregon.

9 Internal report on the September 12, 1989, Manufactured Housing Data Management Committee (DMC) meeting prepared September 25, 1989, by the Bonneville Power Administration, Portland, Oregon.
10 Internal report on the October 25, 1989 , Manufactured Housing Data Management Committee (DMC) meeting prepared November 3, 1989, by the Bonneville Power Administration, Portland, Oregon.

11 Internal report on the January 11, 1990, Manufactured Housing Data Management Committee (DMC) meeting prepared January 22, 1990, by the Bonneville Power Administration, Portland, Oregon.

12 Internal report on the February 13, 1990, Manufactured Housing Data Management Committee (DMC) meeting prepared March 6, 1990, by the Bonneville Power Administration, Portland, Oregon.

13 Internal report on the April 12, 1990, Manufactured Housing Data Management Committee (DMC) meeting prepared April 24, 1990, by the Bonneville Power Administration, Portland, Oregon.

14 Internal report on the June 27, 1990, Manufactured Housing Data Management Committee (DMC) meeting prepared July 12, 1990, by the Bonneville Power Administration, Portland, Oregon.

15 Internal report on the August 2, 1990, Manufactured Housing Data Management Committee (DMC) meeting prepared September 11, 1990, by the Bonneville Power Administration, Portland, Oregon. 


\section{CHAPTER 12: RCDP TAKES OFF -- The Proof is in the Program!}

Outwardly, the RCDP had moved somewhat slowly throughout the summer of 1988; spirits at the first DMC meeting on November 2, 1988, and the Work Group meeting the next day were not running high. Nevertheless, the participating manufacturers were "hanging in," and some of them -- perhaps to their surprise -were selling more and more Super Good Cents/ RCDP homes. The Manufactured Housing Work Group meetings had continued and were growing ever more spirited, if not always larger. Several key manufacturers remained interested in RCDP developments and participated wholeheartedly in the Work Group meetings. The group, over time, had become in every sense a true team. ${ }^{1}$

It is likely that at least some of the continued manufacturer interest was stimulated by the keen competition within the industry. Participating manufacturers couldn't help but notice that some of their number were extremely successful in selling the Super Good Cents/RCDP homes and wanted to sell even more (see Box - 50 Homes per Manufacturer Policy). At the same time, Bonneville had taken great pains and every opportunity to keep all regional manufacturers informed and motivated whenever there was occasion to do so. Through this combination, industry involvement and interest was sustained throughout the RCDP period.

Judging from the kinds of discussion taking place at the Work Group meetings, the project had lost some of its identification as simply a Bonneville exercise; as participants learned to maneuver the bureaucratic shoals of the program, they began to see that the sales potential was, in fact, significant, that the homes could be built to specifications, and that the RCDP incentive could move the product. Magic words in any business.

If industry interest had been sustained and even stimulated, so had that of many dealers,

\section{HOMES PER MANUFACTURER POLICY .}

When RCDP was designed in the summer of 1987 , one of the ground rules built into the demonstration project was that no participating manufacturer would be permitted to build more than 50 homes. This policy was established so that the test would involve a sufficiently broad sample of the industry.

By fali 1988, seven manufacturers were participating in RCDP and the consensus was that this was a good cross-section; in fact, the initial "sample" was broader than that achieved for the RCDP Cycle I site-built innovations.

Some of the more aggressive manufacturers asked that Bonneville review this policy and at the November 3 , 1988, work group meeting it was agreed that the policy should be dropped. In effect, this was a highly competitive stance taken by the manufacturers who had discovered the sales potential of SGC - and a not-sosubtle message not overlooked by RCDP participants and non-participants alike.

many utilities, and many prospective home owners. Difficult as it may be to pinpoint which segment or diverse interest in this "marketing mix," drove events in late 1988, the effect was clear enough -- new ideas were developing in several quarters and enthusiasm for marketing energy-efficient manufactured homes was growing across the board!

Some of the stimulus was artificial and unintentional -- because the higher RCDP incentives had been guaranteed for only 150 homes, at this stage the future was uncertain. But it was clear that the RCDP participants were beginning to reassess, at some level, the potential of energy efficiency to impact sales of manufactured homes. What at first had been a kind of "shotgun marriage" -- an awkward imposition of costly features and troublesome specifications into a price-sensitive, competitive market -- evidently began to make sense (somewhat all at once) to manufacturers, dealers, and consumers. 


\section{Dealer Initiatives}

One major reason these homes soid, noted by perceptive dealers, was that buyers evidently equated the Super Good Cents homes with quality (Onisko 1989). Without necessarily knowing or caring abcut the specific benefits the energy-saving options provided (partly no doubt because of the region's long-standing reliance on low electric rates), consumers were nevertheless impressed that something was different about these homes and that something indeed had value. And, for the time being at least, this something was virtually free!

The RCDP incentives made it possible for a prospective buyer to acquire a home with energy-efficient features (and its "aura" of quality construction) at no extra cost. The key factor not to be overlooked is that during this period consumers -- even though they were not particularly responsive to the idea of saving exergy -- began to perceive that somehow the Super Good Cents/RCDP homes provided genuine extra value. Without this perception, incentives would not have been truly effective. A general marketing truth is that a price incentive alone, no matter how high, cannot induce customers to buy an item perceived as non-beneficial. Or, putting it another way, price incentives work best when they are applied to products people already want!

Throughout the summer and into the fall of 1988, slowly but surely, the Pacific Northwest's inanufactured home buyers had obviously been persuaded to want the quality they saw in Super Good Cents/RCDP manufactured homes. But it wasn't that simple or automatic; as Super Good Cents/RCDP homes were being sold, it was not a matter of writing up easy orders because of subtle changes in buyer perceptions. People still weren't coming onto dealers' lots and asking for Super Good Cents/RCDP homes!

Other factors were at work. Key dealers were selling the consumers with a strong emphasis on a cash-back bonus. Instead of keeping the Bonnevills incentive, manufacturers had opted to include the upgrade costs in their price to the dealers while passing through the incentive to the dealer, earmarked as a buyer's incentive. Although in the long run this was more costly because the manufacturers and dealers were now taking a mark-up on the energy conservation measures, the higher cost may have been offset and justified to a degree by the marketing value of the relatively lucrative consumer offer. The industry had long maintained that its customers were extremely price-sensitive; participating manufacturers were convinced that cash-in-hand would talk louder than a lower price.

With this approach, even though more industry profit was generated and ultimately paid for by the consumer, dealers were able to offer a substantial consumer cash incentive on the spot. The increased price of the Super Good CentsIRCDP homes could be amortized over time while the cash incentive was available in the "here and now." The cash-back offer permitted customers to increase their down payment or pocket the extra cash for moving expenses, furniture, or the countless extra costs of buying and moving into a new home.

Manufacturers expressed the view that the pass-along motivated dealers to participate in the adventure of selling energy-efficient homes and permitted them to make a sale that they may otherwise be unable to make.' In a survey conducted among 39 dealer participants after RCDP had ended, 34 rated the incentives as very important and 4 rated them as somewhat important (Onisko 1989). Rather than using the incentives to simply level the playing field so that energy-efficient homes could compete in price with "regular" manufactured homes, the manufacturers participating in RCDP made a marketing decision to use it as a sales tool instead.

In effect, by passing on the incentive, manufacturers had also taken the dealers into a marketing partnership. They had given dealers a costlier product to sell but they also provided a promotional opportunity. The fact that this 
opportunity was "rationed," i.e., only 150 homes would be eligible, may have been one of the key factors in the sudden burst of sales that characterized the end of the RCDP effort.

\section{Sizing Up Potential}

By November 1988, the participating manufacturers had begun to diverge. About half of them were "going through the motions" but not aggressively selling the concept of energy efficiency. While certainly continuing . to cooperate, their involvement was low-key -one manufacturer sold only one Super Good Cents/RCDP home. These participants remained informed but did not attend the Work Group meeting in November; only two manufacturers attended that meeting. ${ }^{1}$ The attendance level was a crude mirror of the status of the RCDP with many manufacturers at the 8-month mark. Rather flat, rather lackluster, neither a failure nor a success. Wait and see.

But another group was taking a different, far more active view. At the meeting in November, it was clear that some manufacturers viewed the test as a real opportunity; it was also clear they were looking heyond RCDP. One of the key discussions at the November Work Group meeting involved Super Good Cents marketing plans after RCDP "winds down." These discussions strongly suggested that some of the region's manufacturers were approaching the Super Good Cents and energy-efficient manufactured housing as a long-term effort. At the Work Group meeting, manufacturers volunteered to serve on Super Good Cents's advertising advisory committee, made up of the utilities participating in Super Good Cents.

The manufacturers pressed the point that they ought to be full partners in the long-term Super Good Cents marketing program. In their view, the Super Good Cents concept hinged on marketing energy efficiency, not on any breakdown of promotion effort into site-built or manufactured homes. They reminded
Bonneville that manufactured housing, by Bonneville's own estimates, accounted for $50 \%$ of the new housing in many areas of the region and that "utilities ought to be as interested as BPA" $^{n}$ in having all advertising include manufactured housing. ${ }^{1}$

This keen interest in marketing issues and long-term Super Good Cents planning clearly indicated that some of the region's manufacturers saw great potential in marketing energy efficiency as a feature of manufactured homes. It was also clear that they saw Super Good Cents participation as a means of positioning manufactured homes in the context of the total housing market. If that could be achieved, increased sales could be generated by expanding the category not by price wars within a limited, specialized segment of the housing market.

The same manufacturers who advocated increasing the manufactured home "share of the

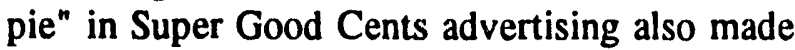
several suggestions to improve marketing effectiveness at the retail, the dealer, level. Although Bonneville was limited in the type of incentive that could be provided to dealers, manufacturer representatives at the November Work Group meeting voiced general support for any effort that would provide more recognition to salespeople actually making the sale. At the same time, they emphasized that the incentive itself was an important tool that gave salespeople a chance to make a sale they might otherwise be unable to make. Other ideas -significantly positioned as having long-term value beyond RCDP -- included special Super Good Cents caps, jackets, pens, etc.

\section{The Final "Push"}

Meanwhile, back at the plants, things were humming along as well; the new techniques had been assimilated. The manufacturers who had taken the "leap of faith" were discovering that they could build homes to Super Good Cents specifications with something approaching their usual efficiency once the awkward -- and 
sometimes frustrating - learning phase was over. The Washington SEO reported that dealers were learning to make good use of WATTSUN runs and some of the earlier problems with specifications and definitions had been straightened out. In terms of plant efficiency and administrative detail, the program was running smoothly but not yet at full volume.

And yet -- looking back -- there were signs that several key events had occurred that were likely to increase the sales momentum. It was really just a matter of time. Any one of these events -- buyer perception of value, trained and sharpened dealer skills, increased manufacturer efficiency (and hence interest in the product) -could have triggered sharply improved sales of Super Good Cents/RCDP homes but sales were simply "so-so" all through the summer and fall of 1988.

Nor was there a sudden sales upsurge following the November Work Group meeting, although November sales were as high as any since the demonstration project had begun (see Table 12.1).

What had been achieved, however, was a clear-cut indication that these homes had carved out a niche in the market that now wouldn't simply vanish. Even though Bonneville had intended that these homes would be sold by the end of the year, it was clearly only a matter of a little more time.
As 1989 began, RCDP was not "limping along" as one might have thought in the first few months of the project. The December and January 1989 sales levels were "respectable," and, in fact, sales at this rate would have achieved the program objectives of 150 homes in the first year if it weren't for the first lowvolume months. What seems to have happened is that participating dealers and manufacturers, realizing that the RCDP was in its final stretch and knowing these homes were saleable, turned up the "heat" and approximately doubled February 1988, sales of Super Good Cents/ RCDP homes. This momentum continued into March; many more Super Good Cents homes than those covered by the RCDP quota were sold and their status, for a time, was uncertain. ${ }^{2}$

The final RCDP sales breakdowns (see Box - Final RCDP Sales Breakdown) first reported in a DMC meeting, ${ }^{2}$ reflect the degree to which RCDP sales varied by manufacturer. As might be expected, those manufacturers who achieved the highest RCDP sales were also among the most active participants in the Work Group process. However, no manufacturer or group of manufacturers dominated the process nor did they seek to do so. The difference in levels of participation was based on several factors: earlier commitment, perception of long-term sales potential, size of plant, ability to dedicate/ invest the required resources, impact on current plant operations, plant schedules, etc.

TABLE 12.1 - RCDP Home Sales

\begin{tabular}{||c|c|c|}
\hline Month & SGC/RCDP Sales & Total SGC/RCDP Homes Sold \\
\hline November 1988 & 19 & 76 \\
\hline December 1988 & 12 & 88 \\
\hline January 1989 & 15 & 103 \\
\hline February 1989 & 30 & 133 \\
\hline March 1989 & 17 & 150 \\
\hline
\end{tabular}




\section{FINAL RCDP SALES BREAKDOWN}

Sales by Climate Zone:

Climate Zone 1 Climate Zone 2 Climate Zone 3 82

66

2

Sales by State:

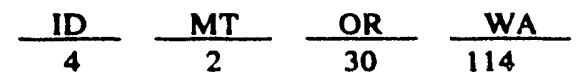

Sales by Manufacturer:

$\frac{\text { Silvercrest }}{9} \frac{\text { Moduline }}{28} \frac{\text { Guerdon }}{4} \frac{\text { Golden West }}{15}$

$\frac{\text { Glen River }}{40} \frac{\text { Fuqua }}{1} \frac{\text { Fleetwood/WA Fleetwood/OR }}{44}$

The final results also show that penetration of the region's colder climate areas was limited; this had been an ongoing concern throughout the project. There were two reasons for this and they were related. First, the manufacturers who participated in RCDP tended to be those located in, and serving, the region's milder climate zones. Second, the Super Good Cents specifications for climate zone 3 were extremely hard to achieve with the window technology used by most manufacturers in 1988 and 1989. As a result, Super Good Cents specifications severely restricted the glazing area in these homes. Manufacturers believed that from a consumer point of view, these homes would be nearly impossible to sell. The issues were related because the stringent regulations for the colder areas were one of the chief reasons cited by manufacturers who did not participate in the RCDP for not joining the RCDP effort initially (Lee and Baechler 1990).

\section{RCDP's Last Work Group Meeting}

The last RCDP Work Group meeting was held in Portland on March 30, 1989. ${ }^{3}$ In many ways, it was typical of such events, with

Bonneville's program managers tracing the arduous beginnings of the project and describing the stress of getting the innovation launched under RCDP auspices, and concluding with kudos for everyone involved -manufacturers, dealers, utilities, SEOs. It was, for the manufacturers and dealers, the end of their chief tasks: designing, building, selling, and siting 150 homes in a real-world test of energy efficiency that would stand as a symbol of regional cooperation for a long time to come.

It was not, however, the end of the research. The sale of the 150th home marked the point at which research could begin in earnest. The DMC's activities over the past 5 months, reported to the Work Group, had helped to clarify the research objectives and requirements. The data on each of the 150 test homes from which the all-important cost-effective analyses would be constructed was being entered into the database and included information on the manufacturer, the original WATTSUN information, the set-up check list, and the homes' locations.

Cost Data - Along with the congratulatory messages, some hard issues were addressed in this last RCDP meeting. As discussed in the previous chapter, the cost data that PNL was collecting from participating manufacturers was a key concern to the DMC. The Work Group was advised that the DMC felt that the cost data that manufacturers were providing to PNL were prices and not the true costs of the energy upgrades of the Super Good Cents/RCDP homes. $^{3}$ Only one manufacturer had been willing to provide separate costs for material and labor, for example. Manufacturers, of course, had made it clear from the beginning that they would not supply information if they felt it could harm them competitively.

At the Work Group meeting, it was pointed out that the cost information thus far developed was, in many cases, questionable. For example, in some cases insulation upgrades were priced the same regardless of square footage. Without separate costs for labor and 
materials, it was difficult to tell where potential savings could be achieved. These costs would heavily bear on the region's future in terms of the incentive levels and overall costeffectiveness of conservation efforts and also in determining which energy conservation measures to pursue. It was emphasized that the cost data situation was unfortunate because the cost data coming out of the program

- was potentially the best information available in the entire United States

- would establish the best values for future programs (with major impact on both manufacturers and home owners).

The Work Group was advised that, in an effort to improve the cost data, the exit surveys PNL was planning to conduct with each participating manufacturer would ask each of them to revisit their cost reports and reconsider some of the reported data. This was an extremely important issue, and Bonneville wanted to highlight it especially for the manufacturers and trade association representatives attending the Work Group meeting. Later in the meeting, the Council also addressed the issue, explaining that the RCDP cost data would be used for two purposes:

- $\quad$ input for federal standard development

- regional cost-effectiveness issues.

The Council emphasized that upgrade costs had to be accurately allocated by component (i.e., walls, ceilings, floors, windows) so that true costs of a measure are accurately reflected in the data. The square footage of these components must be taken into account. The Council stressed it was important for manufacturers to understand how the cost information was going to be used. "Pricing is not necessarily what it costs to produce," the Council cautioned. One of the manufacturers present believed that this relatively sensitive issue could be resolved but that doing so would require "asking the right questions." 3
Bonneville's RCDP manager explained that scripted questions would be prepared and asked during the exit survey to attempt to obtain more specific information than the package price information many manufacturers had thus far provided. Until more specific data could be obtained, RCDP cost data would have to be used very cautiously. Having now been through the energy upgrade process, the manufacturers at the meeting felt they were in a better position to assess the true costs of the energy conservation measures built into the Super Good Cents/RCDP homes.

Understanding had been improved, they assured the Work Group. ${ }^{3}$

Looking Backward - One of the most useful aspects of this meeting took place at the end when participants were asked to review their experience and share what was good and what was bad about the program. What features did they want to carry forward into Super Good Cents? Some of the highlights of that interchange: ${ }^{3}$

- One manufacturer felt that the project was completed because of everyone's commitment to "stick with it." He believed it was a step in the right direction, a unique cooperation between government, utilities, and private industry.

- Another participant assured the Work Group the RCDP experience had left no bad taste. He urged that every effort be made to make the process simpler, "as simple as possible." In net, he believed the program ought to be acceptable to manufacturers.

- In this regard, it was noted by an industry representative that not all manufacturers were enticed, but that the program did entice the largest manufacturers.

- The Bonneville project manager was pleased there were so many more homes in Zone 2 than had been anticipated. 
- Another manufacturer felt the program's success was a compliment to the utilities. "The incentive, the 'push,' came from the utilities," he said, "dealers weren't that interested."

- Asked about the effect of the cash incentives on sales, this Work Group member felt that about $20 \%$ of the home buyer's motivation came from energy-consciousness and $80 \%$ from the cash incentive. Another manufacturer commented that the role of incentives varied, depending upon the home and on the customer. He surmised that energy-consciousness may have been a somewhat bigger factor with the higher end manufactured home customer.

- A manufacturer who had spoken earlier asked to introduce a negative. For $2 \frac{1}{2}$ years, he stated he had heard the terms "stick-built" and "manufactured." "Brothers and sisters," he said, "we use sticks too! And ours are dry!"

\section{The Importance of Demonstration}

Most often, the chief emphasis in research and demonstration projects such as the RCDP tends to be placed on their research aspects. Certainly, in terms of administrative and management time, the research tasks in a typical project require the lion's share of attention. The research also tends to get most of the "publicity," particularly in a technically oriented organization such as Bonneville. And, it tends to be the most expensive. In the case of the manufactured housing RCDP, the research was certainly no small task; the coordination of research efforts spawned a task group dedicated to dealing with research matters - the DMC -- that worked as an effective team long after the more tangible aspects of the project were completed to solidify the research component of the project.

But in the case of the manufactured housing innovation, the RCDP was aptly titled -- the " $D$ " indicated it was indeed a demonstration project. The demonstration aspects of the manufactured housing RCDP were at once unique and also particularly important because they involved and could influence a single industry. Although hardly monolithic, the individual plants making up the industry dealt with many of the same factors and thus were bound to evolve into somewhat similar organizations. Common influences affecting the manufacturers including the following:

- HUD code requirements affected the design and production processes of each of the manufacturers in much the same way.

- Retail mechanisms and outlets were similar and in some cases even involved the same dealers.

- Although prices varied, the industry tended to operate in a relatively narrow price range compared to the entire range of housing options.

- Building materials were in many cases unique and specialized, often because of Federal Manufactured Housing Construction and Safety Standard requirements and/or cost/pricing/marketing constraints, and so the same suppliers were frequently used by several manufacturers.

- Producers essentially competed for the same customer -- customers were likely to make a "category" choice, i.e., manufactured home versus site-built, and then "shop around."

- Price was always a significant if not the dominant factor in developing a total marketing plan -- design, production, promotion, and profit.

While, broadly speaking, these common influences created an industry in which individual firms were more alike than different, there were differences. The region's manufacturers weren't creating "one-of-a-kind" custom homes but they weren't "cookie cutters" either. One key and consistent Bonneville effort was to design its programs and specifications to embrace the entire industry, not simply one segment of it. This desire to 
embrace the entire industry was, for example, the driving force behind BPA's strong attempts to build at least some homes in all climate zones, all price ranges, all models and sizes.

At the very outset of the manufactured housing project, in 1983, as "rumblings" of some type of conservation effort began to circulate, the industry made no attempt to take the initiative. In the minds of many manufacturers at that time, manufactured homes were already being built to higher-than-average energy efficiency. Many producers viewed any additional effort as unnecessary and -- if it pushed insulation levels higher and glazing areas lower - impractical at best and a potential boondoggle at worst.

Bonneville's cooperative approach, inviting manufacturers into the early planning stages through the Manufactured Housing Work Group may have been viewed with suspicion; nevertheless, it was also disarming. Initiating the industry forum in 1986, the meeting that would evolve into a true Work Group, was the key that unlocked the first of several doors. The manufacturers who attended the early meetings in 1986 and 1987 as well as those who did not -- all of them knew what went on at these meetings - began to trust their instincts and the process. Some of them discovered they were willing and able to take the risks involved in participating. Their demonstration that Super Good Cents was workable in the plants and saleable on the dealers' lots was the only proof that a generally conservative industry would accept.

About 6 months after the RCDP had ended, when the case study of the manufacturers participating in the RCDP had been completed, it was decided that a study of the manufacturers not participating in the RCDP could provide useful insight into ways in which the program could be broadened. This study, conducted by PNL among eight Northwest manufacturing plants (one would not participate) revealed that the RCDP's demonstration aspects had clearly played an important role (Lee and Baechler 1990).

$$
\begin{aligned}
& \text { MANUFACTURERS } \\
& \text { INTERVIEWED } \\
& \text { (RCDP Nonparticipants) } \\
& \text { Guerdon Industries (Idaho) } \\
& \text { Kit Manufacturing (Idaho) } \\
& \text { Nashua Homes (Idaho) } \\
& \text { Fleetwood Homes (Idaho) } \\
& \text { Champion (Tamarack) } \\
& \text { Homes Division (Idaho) } \\
& \text { Marlette Homes (Oregon) } \\
& \text { Liberty Homes (Oregon) } \\
& \text { Redman Homes (Oregon) }
\end{aligned}
$$

Most of the nonparticipating manufacturers were located in Idaho and for the most part the interviews were conducted with the plants' general managers. According to the study, "their nonparticipation appears to have been a result of (1) a perception that the RCDP focused on the western part of the region and (2) the tighter MCS requirements for the eastern part of the region."

Every plant in the region was aware of Bonneville's general desire to increase the energy efficiency of manufactured homes and its proposal to research and demonstrate this effort via the RCDP. Information came from several sources, one or more of the following:

- A visit by Bonneville staff, explaining the project.

- Attendance at work group meetings on the RCDP either at Bonneville or in Idaho.

- Communications about the RCDP from industry associations.

- Industry, utility, or Bonneville newsletters.

- Dealers, although the amount of information coming from dealers was described in the report as limited. 
Besides the general perceptions that the RCDP was oriented to the western part of the region and that requirements would be difficult to meet, there were other, more specific reasons, these manufacturers had not participated. Some of the plants were enjoying a production boom at the time and were too busy to participate. One producer was engaged in purchasing an additional plant and other plants were bound by corporate decisions outside the region. There were several comments related to the amount of paperwork and detail required.

\section{Onward and Upward}

From the beginning, the RCDP was viewed as only the first part of a broader, more ambitious scheme -- the incorporation of manufactured housing into the region's Bonneville-sponsored Super Good Cents program. Although manufactured homes had nominally been part of this program since the RCDP began, utilities and manufacturers had developed a common characteristic -- they were both holding off expanding Super Good Cents manufactured housing participation until after the RCDP was over. The manufacturers had an even stronger, more compelling reason: the Super Good Cents incentives were only $\$ 1,000$ per home when not supplemented by the $\$ 2,000$ RCDP incentive (using climate zone 1 as an example). This issue was viewed by the industry as critical -- manufacturers had insisted from the outset that strong incentives were required to offset the higher cost of the Super Good Cents homes because of the price sensitivity of their market.

There is little doubt that the industry was distinctly motivated by the long-term aspects of Super Good Cents participation; regional producers would probably never have participated in the RCDP if the research and demonstration effort hadn't been linked to the longer-term program commitment by Bonneville and the region's utilities. This appraisal is confirmed by the case study of the nonparticipating manufacturers. The case study revealed that all of the plants were likely to participate in Super Good Cents (Lee and Baechler 1990). RCDP, in other words, was an option, only an hors d'oeuvre, Super Good Cents was the main course.

Would it have been so without the RCDP? It appears to be unlikely. The "chargers" in the RCDP - those manufacturers who had surged ahead in sales -- may have temporarily irritated some of their cohorts by garnering "more than their share" of the RCDP incentives, but they performed a valuable service in return! They demonstrated that energy efficiency had sales potential when aggressively pursued. They demonstrated that they were going to pursue it. The writing was on the wall. Without RCDP, the message could never have been so clear or so convincing.

In terms of technical issues, the RCDP uncovered and resolved problems with the specifications, with suppliers, and with equipment and materials. In terms of process and administration, the project was a useful means of ironing out the initial difficulties faced by a large number of organizations unaccustomed to working together, determining training needs, and coping with paperwork. The RCDP had launched a unique body, the DMC, to look first at research issues and subsequently at broader technical issues that affected the region's goal of producing energyefficient manufactured housing. And finally, the RCDP had tempered the Work Group into a cohesive regional team; it helped an incredibly diverse group of people learn to work together toward a common vision.

$* * * * *$

Like so many other times during the effort to make energy-efficient manufactured housing a fact of life in the Pacific Northwest, this point in time -- March 30, 1989 -- was a significant one. The RCDP had been successfully completed. Without a hitch, a new effort -broad-scale Super Good Cents participation by all the region's utilities -- began the same day at 
the same meeting. The transition was almost imperceptible. With the SEOs trained and casehardened by the RCDP, with the manufacturers and the utilities aware of the potential and the pitfalls of producing and marketing energyefficient homes, and with the DMC and the

\section{End Notes}

1 Internal report on the November 3, 1988, Manufactured Housing Work Group meeting prepared November 30, 1988, by the Bonneville Power Administration, Portland, Oregon.

2 Internal report on the March 29, 1989, Manufactured Housing Data Management Committee (DMC) meeting prepared April 20, 1989, by the Bonneville Power Administration, Portland, Oregon.
Work Group in place to coordinate the technical, marketing, and administrative issues that were sure to arise, the prospect was simply a new, almost familiar, almost comfortable, phase of an astonishing evolution.

3 Internal report on the March 30, 1989 , Manufactured Housing Work Group meeting prepared April 21, 1989, by the Bonneville Power Administration, Portland, Oregon. 


\section{CHAPTER 13: MAINTAINING MOMENTUM -- Super Good Cents and Beyond}

When the RCDP ended, at the end of March 1989 , the final burst in sales of energy-efficient manufactured homes had generated considerable enthusiasm. Optimism filled the air. The demonstration clearly was a success; it wouldn't take the scheduled, more detailed research analysis to convince most RCDP participants (manufacturers, dealers, energy planners, SEOs) that the RCDP "experiment" had been encouraging, to say the least. The energy conservation measures tested during the RCDP had obviously lowered the amounts of electricity required to heat manufactured homes; the open question was the exact degree of cost effectiveness the measures had achieved.

The last-minute surge in sales was heady stuff; the desire to press forward was strong. However, if Bonneville were to follow its normal course, it would be months before the RCDP results could be fully analyzed. The prospect of delay was particularly frustrating at this positive point in time because, directionally, the answer was hardly in doubt. Fortunately, the energy savings demonstrated during the RCDP were substantial enough to justify some risk-taking by Bonneville. At the same time, the sales results the energy-efficient Super Good Cents manufactured homes had ultimately generated were impressive enough to justify risk-taking on the industry's part as well.

The vehicle for maintaining momentum was Bonneville's ongoing Super Good Cents program. The eventual inclusion of manufactured homes in Super Good Cents was never in doubt. Super Good Cents had provided the "template" -- the underlying structure and rationale for Bonneville's overall plan to develop energy savings in the manufactured housing sector -- since the decision to focus conservation effort on new manufactured homes as recommended in the retrofit study in 1984 (Onisko and Van Orden 1984). The specifications tested during the
RCDP were modified Super Good Cents specifications, the incentives were based on Super Good Cents incentives, the marketing support was Super Good Cents support. From the manufacturers' perspective, the image of quality that the Super Good Cents designation provided manufactured homes was evidently a major benefit of their participation in the energy-savings effort. Hence, the decision to maintain sales and production momentum by initiating Super Good Cents was not surprising; what was unusual was the bold move to launch the program before conclusive cost-effectiveness data was in hand.

It appears that Bonneville had learned, too, from the RCDP effort. While manufacturers learned about energy efficiency, Bonneville had grasped good lessons about marketing and timing. The give-and-take atmosphere that had evolved in the Work Group meetings had engendered true teamwork during the RCDP effort. The effects of participation were evident. Manufacturers were at least slightly more tolerant of the administrative requirements; utilities had come to understand the industry's need for smooth, standardized plant procedures; and SEOs played the "gobetween" roles that had crystallized with more sureness. For its part, the process had made Bonneville a much more savvy, marketingoriented "team player" than it had been at the outset.

\section{Super Good Cents's First Work Group Meeting}

On March 30, 1989, the Work Group meeting scheduled at the Red Lion/Coliseum Hotel in Portland, Oregon, was a historymaking event. It featured a new "mix" of participants and a dual agenda. ${ }^{1}$ It was in many ways a landmark meeting, the first that would be scheduled under combined auspices. Half the agenda of the Work Group meetings from 
this point forward would be devoted to the past, i.e., the unfolding and more definitive RCDP results; the remaining agenda would concentrate on the present and the future represented by the Super Good Cents marketing program and the experience and issues this activity generated.

At the first such meeting in March, Bonneville confirmed for Work Group members that the RCDP had been completed and that the analysis was about to begin. After a bout of self-congratulation to be expected at such events, a bold move was announced. An interim Super Good Cents incentive program, tailored as closely as possible to the successful RCDP "formula," had been authorized. The overall purpose of this effort was to maintain the extremely encouraging momentum of the market - to maintain "business as usual," which had become very good, indeed. "Business as usual" was, in fact, highly unusual. Keeping the manufactured homes program as intact as possible, the interim program would be administered by the permanent New Residential project staff at Bonneville'

In the sea of faces that day, many were new and most of these were Bonneville and utility staff members who would administer the continuing program. Providing a broad regional cross-section, these individual managers carried out ongoing Super Good Cents operations throughout the region (see Box - Bonneville's Regional Network). Along with these "newcomers," the most seasoned manufacturers and industry representatives, those who had taken part in activities from the beginning and participated in the RCDP, were at this landmark meeting. Evidently, most of the non-participating manufacturers were "holding fire" until they learned what Bonneville and the region's utilities would propose. These manufaciurers were, to some degree, the more conservative, more cautious members of the industry; they were also, it would be learned, the manufacturers whose markets tended to be in the region's colder climate zones (Lee and Baechler 1990).

\section{BONNEVILLE'S. REGIONAL, NE'IWORK}

Bonneville operates through a regional network. Administratively, the region is divided into four areas that, even today, are required to translate regional programs and operations to widely varying local conditions. Each of BPA's major "headquarters" activitica has an area office representative who is responsible for implementing central programs and providing local feedback. Area office managers and the chiefs of each BPA office constitute Bonneville's Policy Committee, ensuring regionwide representation at an effective administrative level.

The areas and their offices are:

$\begin{array}{ll}\text { Puget Sound } & \text { Scattle } \\ \text { Lower Columbia } & \text { Portland } \\ \text { Upper Columbia } & \text { Spokane } \\ \text { (Montana) } & \text { (Missoula) } \\ \text { Snake River } & \text { Walla Walla } \\ \text { (Idaho) } & \text { (Boisc) }\end{array}$

Activities include operations and maintenance, power sales, and ongoing conservation programs. For the manufactured housing project, the effect of the shift from a centrally administered test program to a regionwide program administered through the area offices was to bring BPA, the manufacturers, the utilities, and the SEOs even closer together.

Bonneville proposed an interim program that would operate for 3 months, until July 1, 1989. In July, manufactured homes would be included in Bonneville's Super Good Cents program until December 31, 1990. Bonneville stressed that its decision to directly launch the interim and the follow-up Super Good Cents programs was not based on completed research but on its desire to maintain continuity, to preserve the encouraging momentum. Unlike most Bonneville actions in its conservation activities, the decision had been based not on research but on judgement, not on formulas but on common sense, not on results but on faith, not on "offagain/on-again," but on consistency.

For both the interim program and the continuing program, incentives were continued, and the following incentive levels were proposed levels: 


\section{$\$ 2,000 \quad$ Climate Zone 1 \\ $\$ 2,500 \quad$ Climate Zone 2 \\ $\$ 3,000 \quad$ Climate Zone 3}

Bonneville had put careful thought into designing the transition program and had taken pains to leave as many of the RCDP elements in place as possible. For example, even though the contractual relationships would be entirely different, SEOs would continue to provide the interface for qualifying homes; this was different from site-built practice where the utility qualified the homes as meeting Super Good Cents specifications. Even so, the qualification process would be technically different because the inspection would serve a different "master;" utilities and not Bonneville would be paying the incentive. As a practical matter, however, manufacturers would not be forced to undergo another "shakedown" and would continue to deal only with their by-nowfamiliar SEO representative instead of the utility inspectors at the home's eventual site.

Even so, and not surprisingly, there were issues to resolve at that trail-blazing first meeting. A new working and contractual relationship was being forged -- between utilities and manufacturers -- and the industry was concerned about the differences among utilities. In some cases, these distinctions were clear-cut and potentially troublesome. Some utilities simply didn't pay the same incentives as others. Utilities would perform on-site inspections and there were likely to be differences in procedures, in approach, in any number of nuances. Given the nature of the manufactured housing industry, its tradition of standardization -- its reliance on it, in fact -these concerns were not to be taken lightly.

More voices needed to be heard as well. Other regional institutions were now involved and perspectives were often dissimilar. Some utilities were PUDs, some were private independently owned utilities. Regardless of ownership, other factors -- financial status, cost and availability of energy, and the utility's relationship to Bonneville -- were different.
These factors bore importantly and decisively on the incentive levels that various utilities were able and/or willing to pay for conservation. The variety and contrasts of the region were mirrored in the participants and their concerns. ${ }^{1}$

Because of the differences in utility priorities, power availability, and procedures, method of payment was an early issue. Closely linked to this issue was that of inspection. Money was changing hands and utilities wanted mechanisms to ensure that the conservation measures they were paying for were, in fact, built into the Super Good Cents homes. Utilities were uneasy about the inspection process. For their part, manufacturers were concerned about the pin-point timing that inspections by individual utilities would require. For example, filling the roof cavity with the required insulation was typically a rapid, 45minute process. If an inspector didn't happen to be in the plant at just the right moment, that manufacturer nemesis -- a line shutdown -could occur. In the end, Bonneville's recommendation to have in-plant inspection carried out by the IPIA and certified by the manufacturer carried the day. ${ }^{1}$

One of the most provocative issues to arise was whether the Super Good Cents specifications developed for the RCDP would satisfy utility requirements. At this point in time, a controversy was beginning to develop. One PUD along the I-5 Corridor had refused to allow heat pumps to qualify an Super Good Cents/RCDP manufactured home that did not meet minimum envelope requirements. This incident triggered manufacturer concerns that they could end up serving over 100 masters -each utility participating in the Super Good Cents program. For their part, utilities -particularly those with strong conservation programs of their own -- were adamant that they would not be coerced into paying for energy savings achieved by energy conservation measures that their own research and experience had demonstrated to be not cost-effective. ${ }^{1}$ Several utilities were beginning to agree that any manufactured home for which they paid an 
incentive should meet minimum shell requirements. When it became clear they would not back down, Bonneville promised that this issue would be broadly aired and understood by including a discussion of the question in a technical update circulated soon after the meeting. ${ }^{2}$

In spite of disagreements at this meeting, utilities and manufacturers were able to air many of their respective concerns in a surprisingly good-natured manner. They did not so much solve problems that day as lay the groundwork for working them out. And, it appeared, they began to develop some mutual trust. In the final analysis, the "players" were beginning to sense that the self interest of all parties was best served by building bona fide energy-efficient homes for the region. Longterm investments for the region, not short-term gains for either utilities or manufacturers, were the prize that was being identified and the goal that was being set. ${ }^{1}$

\section{Continuing Work Group Meetings}

There wasn't any real precedent for continuing the Manufactured Housing Work Group meetings once manufactured homes were incorporated into the Super Good Cents program after July 1, 1989. But the Work Group had become an extremely functional institution; the experience of working together had forged new relationships, an intimacy, the beginnings of trust. Like the DMC (see Chapter 11), the Work Group had become a useful forum. It was a convenient means of communicating information, soliciting feedback, developing a regional consensus, achieving cooperation. Although perhaps less tangible than the 150 Super Good Cents homes that had been constructed and sited for the test and demonstration, the Work Group as it now functioned was just as much a legacy and an accomplishment of the RCDP as the homes themselves.

In part, these meetings had worked well because of the close-knit nature of the industry.

\section{'TYPICAL, WORK (YROUP MEETIN(; AGENDA}

(October 26, 1989)

This agenda is a good example of tho type and range of subjects treated in the work group mectings during this period (BPA 1989c):

- HUD/MHI Update

- SGC Manufactured Housing Program

- Lender's Incentive for SGC Manufactured Housing

- SGC Manufactured Housing Work Plan

- Update: Manufacturer and IPIA Training

- Encrgy Smart Team Activities

- Marketing Program (Snohomish, Tacoma, and Puget Power)

- Updatc: 1990 SGC Ad Campaign

- Manufacturer/Dealer Markcting Prefurences - Lunch -

- RCDP Update

- Manufacturers Case Study

- Dealer's Exit Survey

- Encrgy Use Monitoring

- Infiltration Testing

- Data Management Committec

- DMC Updalc

- Task Order Analysis Contract

- Task Order Schedule

- Cost-Effectiveness Analysis

meetings were nothing new; site-built homes had been part of the Super Good Cents program since its inception, and many builders and contractors had also participated in the original research and in subsequent task groups. But these participants lacked the innate cohesiveness of the manufactured housing industry. HUD code builders already had a relatively long history of working together, a relatively more "common cause," and were, because of federal codes and manufacturing processes, more similar to one another than not.

Qctober 26, 1989, Meeting - At this stage, the Super Good Cents program had completed a somewhat awkward transition; by this time the 
contracts required to get the SEOs "up and running" were in place. As the scope of the program now expanded to cover the entire region, many more potential dealers, manufacturers, utilities, and home owners were involved and the SEOs were required to play a more demanding and pivotal role than they had in either the Super Good Cents site-built program or the more limited RCDP. In developing the contracts, Bonneville project managers had been careful to rely on RCDP experience and manufacturer input to guide the development of negotiations. The contracts called for the SEOs (Washington, Oregon, Montana, and Idaho) to provide ${ }^{3}$

- in-plant marufacturer training

- ipia training

- dealer training

- design qualifications

- on-site inspection assistance.

An important issue discussed at this meeting was a review of HUD's progress toward a new energy standard and the MHI's response. The MHI had formed a consensus committee and hired a consultant to provide an industry response to HUD's rulemaking. The Council had taken the lead on following this issue and reviewed the situation with participants. ${ }^{3}$

\section{RCDP UPDATE}

The work group meetings functioned as a forum for updating the manufactured housing industry and other participants on Bonneville's progress in developing final reports on the energy performance and cost effectiveness of the RCDP homes.

By the end of 1989, an analysis contractor had been secured, interim cost data was in hand, and case studies of manufacturer and dealer participants in the RCDP had been completed. Plans for the upcoming infiltration study were outlined and explained.

Marketing issues seemed to be dominant as indicated by the day's agenda which was, in many ways typical of the Work Group meetings held during this period (see Box - Typical Work Group Meeting Agenda). An advantage for manufactured housing under the Super Good Cents "umbrella" was that participating plants could now benefit from the professional marketing services provided by the Energy Smart Team -- a regionwide marketing support group contracted to Bonneville to assist in marketing Super Good Cents and other programs. Team members were active participants in this and future Work Group meetings.

The Energy Smart team had developed a highly successful promotion that had initially been run by three utilities in the I-5 Corridor. Before the meeting was over plans were drawn for regionwide use of this promotion, supported by an 800 number. The formation at this meeting of a regional marketing network of HUD code manufacturers was an unusual, unexpected but positive outgrowth of Bonneville's quest for energy-efficient manufactured housing. While energy efficiency had been the driver creati $g$ closer industry cooperation, the manufacturers had begun to sense there was even more to be gained. Although it was never completely articulated, the Super Good Cents provided the industry a vehicle for expanding its share of market via an improved quality image. ${ }^{3}$

May 9, 1990, Meeting - A year into the Super Good Cents program, the issues and concerns of the Work Group remained focused on marketing, impending research results, specifications, and training. Not much different, really, than the issues and concerns that arose at the first meeting. What was different, however, was that the tenor of the second meeting was significantly more oriented toward solving problems, toward finding ways to maintain and increase the momentum that had never been lost. ${ }^{4}$

This was the first meeting at which a revolutionary idea was broached, half in jest. The Bonneville manager of the Super Good 
Cents program (both site-built and manufactured housing) was discussing longterm planning for Super Good Cents, trying to give participants a sense of what was likely to happen and to solicit their input. As he explained, Washington State had recently adopted a stringent new energy code, based on the MCS, and as a result nearly $70 \%$ of the site-built horres in the region would be required to be energy efficient. It was only a matter of time before the other Pacific Northwest states would follow. This, of course, rendered the continued effectiveness and need for Super Good Cents questionable. The program had served and would soon perhaps outlast its purpose for site-built homes.

A though Bonneville had taken steps to continue the Super Good Cents manufactured housing program through June 1991, it seemed unlikely that Super Good Cents could or should continue into the indefinite future if its only participants were manufactured homes. While sales continued to grow each month and had been encouraging on a relative basis, the effort hao started from "scratch." Total penetration of energy-efficient manufactured homes achieved by the Super Good Cents effort had been only $2 \%$ in 1989 versus a $23 \%$ penetration rate achieved for site-built homes. ${ }^{4}$ And, as the participants well knew, the number of people required to cocrdinate the manufactured housing effort was significant - and disturbingly high for the modest results achieved. It was essential that any long-term approach would have to reduce administrative overhead. At this point, the program manager, reviewing some of the pussibilities, outlined three alternatives: ${ }^{4}$

Pay Manufacturers Directly - This would require sending a RFP to the region's 17 manufaciurers and possibly to other associations and/or SEOs. The questions would revolve around who should be included in the purchase negotiations and whether this approach would accomplish what needs to be done at less overall cost.
And then, the program manager said:

A wilder variation on this approach is simply to buy every home in the region and have it built to energyefficient specifications.

Have Local Code Officials Do Site Inspections Why not provide training to local code officials so that they could perform the additional inspections? This would permit utilities to "back off" from the intensive role they were required to play at this time.

Continuing Along Present Lines - This would continue the Super Good Cents effort which in effect was focused on the consumer, motivating the consumer to demand the energy-efficient home via a combination of promotion and incentives.

To help gain insight, perspective, and feedback on these broad questions and issues, the project manager announced that he and Bonneville staff members intended to travel the region and talk with manufacturers during the summer of 1990 . Utilities would be brought into the dialogue through Utility Round Tables (another Bonneville public process). The states would also be involved if Bonneville opted to have site inspections performed by "the code route."

November 8, 1990 Meeting - Technical and research issues were discussed during the morning, marketing and other issues in the afternoon. By now PNL had completed its preliminary cost data report (Weakley et al. 1990); the cost data in this report were subsequently revised by Ecotope in the course of their cost effectiveness analysis (Baylon, Lubliner, and Davis 1990). These revisions were based on additional cost information that Ecotope and the Washington SEO developed by direct contact with the primary component suppliers to the region's manufacturers. In addition, an initial report of the thermal performance of the RCDP homes and the cost effectiveness of the energy-sav ng measures, 
based on a computer simulation, had also been completed and circulated to the Work Group (Baylon et al. 1990).

Ecotope reported on the status of a major project to provide a heat loss reference manual for manufactured homes. The format would be based on a similar reference work Ecotope had prepared for Super Good Cents site-built homes (Baylon and Heller 1988). The content would be based on the specifications used for the RCDP, modified by the RCDP experience and by the results of an in-plant review of the construction processes used in a dozen of the region's plants operated by eight different manufacturers. Ecotope reported that manufactured and site-built construction practices differ widely at several stages and capsuled three of the most significant examples:

- Trusses are generally used in roof construction and this creates uninsulated "slots" in the ceiling when batt insulation is used and the batt or batts meet the truss. Ecotope reported that six of the eight manufacturers studied used batt insulation. Using foam insulation in the slots can mitigate the loss in insulating effectiveness, but Ecotope argued that the best approach would be the use of blown-in insulation.

- Conventional floor construction methods create a situation in which the central heating duct would typically be sandwiched between the belly blanket and the batt insulation of the floor above. This creates an area around the duct with no effective $R$-value between the interior and the cavity below. The effective U-value of the home's floor is determined not by the extra batt insulation but by the belly blanket below the duct. The solution advocated by Ecotope was to cut the batts and ensure that they are positioned on the underside of the central heating duct.

- Wall construction techniques used by the industry utilize less wood than site-built methods, permitting the use of more insulation and resulting in better U-values. Increased efficiency results because wood is, essentially, a poor insulator compared to other insulating materials in common use.

Much of the meeting was dominated by discussion of the future of the Super Good Cents program and the impact of the current uncertainty on marketing effectiveness. Some utilities were discouraged by the low penetration ( $5 \%$ was reported by one) achieved by the Super Good Cents in their service territories. ${ }^{5}$ But this view was not universal and was definitely not shared by manufacturers; one manufacturer reported that $33 \%$ of its production was now Super Good Cents. Other manufacturers reported somewhat lower figures, in the $10 \%$ to $20 \%$ range. At the dealer level, however, the discrepancies in performance were even more marked. One dealership estimated that fully $70 \%$ of its sales were Super Good Cents homes, strongly suggesting that more dealer involvement may be the key to higher penetration. Following are some of the suggestions proposed at the meeting:

- Make demonstration homes available on dealer lots.

- Build closer utility/dealer liaison.

- Reduce the communication barriers/lead time/administrative delays.

\section{The Specifications Review Committee}

Throughout this period, a busy one for Bonneville in conservation matters, a great deal of coordination was required to orchestrate various activities that impacted one another. In the area of technical specifications, for example, the manufactured housing project was only a small part of a much larger and ambitious Bonneville project to revise the entire Super Good Cents technical specification. A great deal had been learned from field experience since 1987, when the present Super Good Cents specifications had been 
established. ${ }^{\circ}$ This review effort involved Bonneville's area office staff, utility representatives, and the SEOs, with the Washington SEO as the lead agency.

The review effort was launched on March 8 , 1989 - about the same time that the RCDP was concluding and the interim Super Good Cents program for manufactured housing was beginning. ${ }^{6}$ In fact, the need to incorporate manufactured housing into the Super Good Cents effort was one of the reasons Bonneville undertook the review effort at this time. The project was coordinated by a body called the Specification Review Committee (SRC). The tasks required would be carried out by individual working committees whose chairpersons would also sit on the SRC. Work was divided into four main categories and each of these would become a working commitice. ${ }^{6}$

- ventilation

- heat pumps

- manufactured housing

- general specifications.

Sources of input for the working committees would include

- utilities

- NWEC officials

- RCDP

- builders

- HUD Code manufacturers.

Initial meetings were held in nine locations in March-April 1989; these meetings dealt primarily with site-built issues because there was relatively little field experience with manufactured housing and Super Good Cents; manufactured homes were at this time only a "centralized" test experience. In most cases, however, there was a great deal of interest throughout the region in both the RCDP final analysis reports and in having a well-developed, well-supported technical specification for manufactured housing. This was the exact moment that utilities were beginning to be involved in manufactured housing and most of them were on "new ground" and anxious to learn.

The schedule anticipated development of a draft specification to circulate to all interested parties for comments by October 1, 1989. By January-February 1990 , plans were to have the specification finalized, based on suggestions and comments received in response to the draft. During 1990, support materials -- fine-tuning, WATTSUN changes, training, manuals, etc. -would be developed. Bonneville's (and the SRC's) goal was to have a fully-supported specification ready to implement in 1991.'

The Bonneville manager of the RCDP project was a key member of the Manufactured Housing Working Committee. The chairman of the Manufactured Housing Working Committee was a conservation manager for a midColumbia public utility. Manufacturers who were active in RCDP were also helpful in this effort. In mid-1990, the Working Committee Chairman began to attend DMC/MHTAG meetings to (a) seek input from RCDP participants, particularly manufacturers and utilities, and (b) use the DMC as a channel to keep participants in the manufactured housing Super Good Cents program informed."

\section{New Rules, New Tools}

The system worked; by early 1990 -- on schedule -- the entire revised Super Good Cents specification was in draft. Both DMC/MHTAG meetings and Work Group meetings were often occupied with discussions of Super Good Cents specifications. For much of 1990 and 1991, the specifications for manufactured housing were "in flux." In early 1990, for example, several events were taking place at once -- they were all inter-related and they all affected the Super Good Cents specifications for manufactured housing: 
- regional input into draft Super Good Cents specifications (prepared by the SRC)

- field infiltration study of RCDP homes (by PNL)

- initial thermal analysis of RCDP homes (by Ecotope)

- Super Good Cents program implementation/ experience.

The new specifications were in draft form, and preliminary RCDP analysis indicated several ways in which the specifications could be improved, such as the use of blown-in insulation to avoid insulation gaps and cutting in insulation below the heating duct. The final RCDP reports were still in process and Bonneville management was concerned that new specifications should not be issued if there was any possibility they could change. ' Manufacturers, too, were concerned about such uncertainty; changes meant delays and delays meant loss of vital efficiency. On the other hand, building less-than-optimal Super Good Cents homes was hardly a desirable course.

Without the DMC and the Work Group, the unsettled situation would simply have been unmanageable. Because these mechanisms existed, developments were discussed and participants were kept aware of the situation. Although formal changes in specifications were kept to a minimum, manufacturers were aware of impending change and some of the improvements in construction processes were implemented. In April 1991, the Super Good Cents specifications were officially changed and the region gradually converted to the new standards with conversion mandatory by August 1991 (BPA 1991c). The "reference path," the basic standard that manufactured homes were now required to achieve to qualify for Super Good Cents incentives is shown in Table 13.1.

TABLE 13.1 - SGC Reference Path for Electrically Heated Manufactured Residences

\begin{tabular}{|c|c|c|c|}
\hline \multirow[b]{2}{*}{ Component } & \multicolumn{3}{|c|}{ Climate Zone $e^{(0)}$} \\
\hline & $\begin{array}{c}\text { Zone } 1 \\
(<6,000 \text { HDD })\end{array}$ & $\begin{array}{c}\text { Zone } 2 \\
(6-8,000 \text { HDD })\end{array}$ & $\begin{array}{c}\text { Zone } 3 \\
(>8,000 \text { HDD })\end{array}$ \\
\hline Ceilings (Attic) & $U-0.036$ & $U-0.030$ & U-0.027 \\
\hline Walls (above Grade) & $U-0.054$ & U-0.054 & $U-0.051$ \\
\hline Floors & $U-0.033$ & $u-0.033$ & U-0.033 \\
\hline $\begin{array}{l}\text { Glazing } \\
\text { Maximum Tested U-factor } \\
\text { Maximum Area (\% of floor) }\end{array}$ & $\begin{array}{r}\mathrm{U}-0.40 \\
15 \% \\
\end{array}$ & $\begin{array}{r}U-0.38 \\
15 \%\end{array}$ & $\begin{array}{r}U-0.35 \\
15 \%\end{array}$ \\
\hline Exterior Doors & U-0.19 & U-0.19 & U-0.19 \\
\hline Assumed Infiltration Rate & $0.35 \mathrm{ACH}$ & $0.35 \mathrm{ACH}$ & $0.35 \mathrm{ACH}$ \\
\hline Crossover Duct Insulation & R-8 & R-8 & R-8 \\
\hline Overall U-factor $\left(U_{0}\right)$ & $U_{0}-0.060$ & $U_{0}-0.057$ & $U_{0}-0.053$ \\
\hline \multicolumn{4}{|c|}{$\begin{array}{l}\text { (a) Mechanical ventilation and pollution source control was required in all climate zones. } \\
\text { HDD = heating degree day } \\
\text { Source: BPA 1991c }\end{array}$} \\
\hline
\end{tabular}


In the interim, Bonneville's Super Good Cents program managers contracted for videotape study guides for set-up crews (Sullivan 1990) and for manufacturers (Sullivan and Philbrick 1990). This support material was further buttressed from 1990 onward by the publication/production of additional reference material. These tools included a comprehensive and clear-cut guide to be used by IPIAs for inplant inspections (OSU 1991). An initial version of the Heat Loss Reference Manual was also completed at about this time, providing manufacturers, SEOs, and utilities similarly clear-cut guidelines to follow at the design stage; this publication underwent several updates and a final version of this tool was completed later (Baylon and Davis 1992).

\section{Evaluating RCDP and Super Good Cents}

Both the RCDP and the Super Good Cents were evaluated by outside contractors; such reviews, called process evaluations, have evolved into standard Bonneville procedure. Because the RCDP analysis was (a) included as only one part (20\%) of an extremely broad review of five projects, and (b) included all four RCDP cycles, the amount of attention focused on manufactured housing was scant (Peters 1992). Beyond that, apparently by design, the analysis tended to focus somewhat narrowly on process issues and devoted much of its discussion to SEO contract issues.

The Super Good Cents analysis is a different story. This review provided a fairly complete chronology of Super Good Cents developments and evaluated nearly every aspect of the manufactured housing program, which the report designated as Super Good Cents/MH (Barry and Jennings 1991):

- to document the process of program development and delivery

- to identify strengths and weaknesses

- to provide recommendations pertinent to the future direction of Super Good Cents/MH.
Calling the Super Good Cents/MH "an outgrowth of the Residential Construction Demonstration Project," the analysis failed to appreciate the relatively complex history of the manufactured housing project and to understand that the RCDP was conducted not as pure experiment but to confirm a decision that had basically been made, namely that Super Good Cents should embrace manufactured housing. It also minimized the cooperative nature of the undertaking, virtually overlooking the Work Group and the long history of cooperation that began at its first meeting in November 1986 (see Chapter 7).

Without knowing that a "master plan" had been established long before Super Good Cents/MH was initiated, and that Bonneville, key utilities, and the manufactured housing industry had approached the challenge of building energy efficiency into manufactured homes as a cooperative venture, it is easy to see that the true nature of the Super Good Cents/MH as a kind of "holding operation" was never perceived. The analysis perceived the uncertainty in Super Good Cents/MH as a kind of program flaw, attributing the cause to the lack of measurable objectives.

In fact, Super Good Cents was hamstrung at the outset because of the need to await definitive RCDP data before "nailing down" specifications and objectives. By the time this information was in hand, the manufactured housing project had moved on to "bigger game." This was the idea, introduced in near jest, that perhaps the best way to achieve energy efficiency was not one house at a time but by finding a key to converting an entire industry to make only energy-efficient homes! This idea, the Manufactured Housing Acquisition Program (MAP) was broached in late 1990 and so dominated the situation that Super Good Cents, in many ways, was obsolete before it was even launched! 
Far from being a routine program that needed "fixing," Super Good Cents was perhaps the critical element in the long-term success of the manufactured housing project through all of its incarnations. It was a palpable goal at the outset of the Work Group, a known and respected regional program that offered the manufactured housing industry an opportunity to compete with site-built homes in a new way. It had clear-cut specifications that were known to deliver energy savings of a relatively certain

\section{End Notes}

1 Internal report on the March 30, 1989, Manufactured Housing Work Group meeting prepared April 21, 1989, by the Bonneville Power Administration, Portland, Oregon.

2 Internal report on the October 261989 , Manufactured Housing Work Group meeting prepared November 28, 1989, by the Bonneville Power Administration, Portland, Oregon.

3 Internal report on the May 9, 1990, Manufactured Housing Work Group meeting prepared June 15, 1990, by the Bonneville Power Administration, Portland, Oregon.

4 Internal report on the November 8, 1990, Manufactured Housing Work Group meeting prepared December 1990, by the Bonneville Power Administration, Portland, Oregon. magnitude in a relatively predictable way. Once the RCDP demonstrated that these specifications could be modified to manufactured homes and that these homes could be sold, the Super Good Cents provided a means of maintaining and expanding the program until an even bigger idea could be made tangible and practical. It was never the destination -- only a well-marked, inviting road to the region's ultimate adventure -- a map to MAP!

5 Internal report on the March 8, 1989, Super Good Cents: Specification Review Committee meeting in Portland, Oregon, prepared March 15, 1989, by the Bonneville Power Administration, Portland, Oregon.

6 Internal report on the April 18, 1989, Super Good Cents: Specification Review Committee meeting in Moses Lake, Washington, prepared May 21, 1989, by the Bonneville Power Administration, Portland, Oregon.

7 Internal report on the June 27, 1990, Manufactured Housing Data Management Committee (DMC) meeting prepared July 12, 1990, by the Bonneville Power Administration, Portland, Oregon. 


\section{CHAPTER 14: MAP -- The Ultimate Conservation Program!}

MAP was an inspired, creative, unique, positive response to several "roadblocks" in the region's drive to achieve energy efficiency in new manufactured homes built and sited in the Pacific Northwest. Essentially, MAP was spawned and fostered by the idea that there ought to be an easier, simpler means of acquiring now-known energy savings. As Bonneville, the utilities, the manufacturers, the Council, the SEOs, and others were working hard to advance the Super Good Cents approach, frustrations were growing - for different reasons. Utilities felt that penetration wasn't increasing fast enough, the Council felt that not enough energy savings were being pursued, the industry felt there was too much paperwork and not enough certainty, SEOs were strained by staff resources, while Bonneville was beleaguered by all these concerns and the costs and inefficiencies they created.

But different as they were, and diverse as their interests, all these players were on the same stage; in many cases, they had now been working together for years. With the same serendipity that had seemed to bless the manufactured housing project in the past, the Super Good Cents provided a kind of safe haven while the idea of MAP could first be given form and then negotiated. With the trust and familiarity bred by Work Group efforts, continued through RCDP and, now, Super Good Cents, participants reached out for new roles and new consensus. The result was not

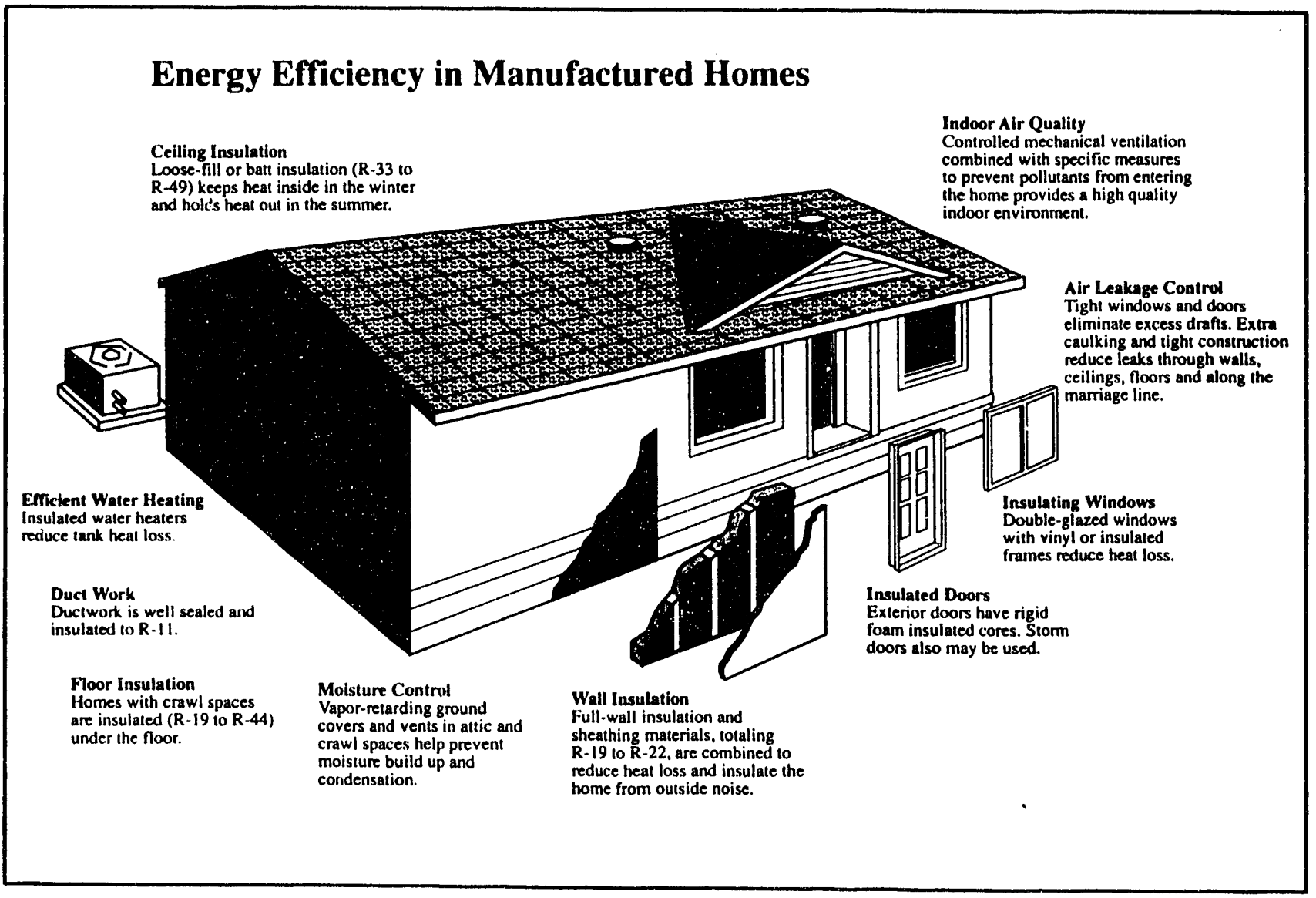


only a new program to achieve energy conservation, it was yet another "new world" opened by the manufactured housing project.

The core idea underlaying MAP was simple enough. It called for nothing less than acquiring all regionally cost-effective electric energy savings via the most direct means possible, i.e., contracting directly with manufacturers. And all meant all. Not some cost-effective energy conservation measures. All cost-effective energy conservation measures. Not some electrically heated manufactured homes. All electrically heated manufactured homes. Not some manufacturers. All manufacturers. Not some of the region's utilities. All of the region's utilities.

Such audacity required an extraordinary stimulus, an extraordinary approach, and extraordinary trust. By the end of 1990 , developments in the manufactured housing project had brought all of these to just the right stage for MAP to be successfully crafted out of all the experience, both good and had, that had gone before.

\section{The Stimulus}

Much of the stimulus for MAP arose from a series of potentially negative conditions and/or developments in several key areas:

- Super Good Cents Uncertainties

- specifications

- long-Term Super Good Cents Planning

- HUD Code Developments

- MHI Consensus Committee

- Council Recommendations

- Utility Hook-Up Fees

- Regional versus Consumer CostEffectiveness.

Super Good Cents Uncertainties - Much of the time, the Super Good Cents program was conducted in a state of "eclipse." When it first began, in the spring of 1989 , Super Good Cents operated in the shadow of the RCDP program, awaiting research results and Bonneville's pending revision of the Super Good Cents specifications. Later, the future of the program was uncertain because of impacts beyond the control of program participants.

Specifications - Throughout 1989 and much of 1990, the anticipation and discussion of the final $R C D P$ research results was as much a part of Super Good Cents Work Group meetings as concerns about day-to-day Super Good Cents operations. While program elements were not in question, and participation was growing and becoming more routine, the question of specifications was troublesome. All participants knew that the specifications would change as a result of the RCDP findings and that these changes would be incorporated into Bonneville's overhaul -- through the Specifications Review Committee (SRC) -- of Super Good Cents specifications for both sitehuilt and manufactured housing.

\section{A BRIDGE TO SUCCESS}

The Super Good Cents effort played a vital role in bridging the tremendous gap between the initial research and demonstration effort and the final plan to upgrade every munufuctured home in the region. Under SGC, the program expanded from 8 to all 17 manufacturing plants in the region. It expanded buyer participation from 5 homes or a month to $100+$ by December 1990 and $150+$ by the summer of 1991 . It showed utilitics and manufacturers alike that energy efficiency was a workable, paying proposition. It gave manufacturers the time to improve components (particularly windows) and ferret out suppliers for the new type of home they were building. It permitted the initially opposed objectives and almost natural hostility of manufacturers and utilities to evolve into profitable cffort for each.

Long-Term Super Good Cents Planning - The region's long-sought objective of achieving energy savings through stronger energy codes was beginning to be realized. Washington, the region's most populous state, enacted a strong 
energy code, patterned on the MCS, in 1990. Indications were that the region's other states were soon to follow. As discussed in Chapter 13 , once codes were in place there would be no need for Super Good Cents for site-built homes. There was little enthusiasm for continuing Super Good Cents as a manufactured home program only, and even less for the inefficient, resource-intensive methodology that had evolved.

HUD Code Developments - A development with potential influence on the Super Good Cents program was the development of a new HUD code energy standard which was generating an industry-wide, national dialogue. In theory, if the new standard were rigorous enough it could render Super Good Cents unnecessary.

MHI Consensus Committee - The primary action in this quarter was taken by the MHI which undertook the development of recommended new standards and industry consensus on their implementation. Although the MHI was invited to participate in the RCDP (via DMC membership) and results had been faithfully communicated to them at every stage, they had evinced no real interest in the revolutionary events that were changing the manufactured housing industry in the Pacific Northwest.

Council's Recommendation - While HUD would eventually play the key role in establishing any new standard, HUD, too, had declined the invitation to participate in the Northwest upgrade experiment. In June of 1990, the Council tried another tack. It passed a formal resolution asking HUD to establish the Northwest as a separate climate zone (based on HUD's mandate and standard) and to declare the MCS the standard for this new zone.

Utility Hook-Up Fees - If these events weren't enough, an even darker shadow was cast by yet another approach to achieving energy efficiency. In 1990, a different mechanism began to gain converts among utilities -- the imposition of a utility hook-up fee for any new home not meeting minimum energy-efficiency standards. If Super Good Cents was a "carrot," the idea of hook-up fees was a "stick," a development and a technique that ran counter to Bonneville's approach and the Super Good Cents program most utilities were undertaking to encourage more energy-efficient manufactured homes in their service territories.

Nevertheless, the argument had some appeal and validity for some of the region's utilities. It could be, after all, fast if not friendly. Faced with runaway energy consumption, utilities with needs for more power resources felt they had the right (if not the obligation) to discourage inefficiency and to allocate the costs of new energy resources to those who made them necessary. Legalisms filled the air - - was this preempting the HUD standard or was it simply a rate issue? -- and the future of attorneys in the Northwest seemed bright.

But, at the heart of the matter, neither the region's utilities nor the region's manufactured housing producers had much enthusiasm for spending their hard-earned profits and perhaps the rest of their lives in court. By this time, utilities and manufacturers had, in some cases, over 4 years' experience in working together. While it was obvious that they were often at cross-purposes, it was equally obvious they had more often than not reached workable solutions. The utility/manufacturer dialogue was critical because, even though Bonneville was writing the checks, the serving utility ultimately paid for the Super Good Cents incentives. The interchange and disagreement between manufacturers and utilities was more than idle conversation -- money was changing hands. This was where the "business" of conservation was conducted.

Cost Effectiveness - Determination of cost effectiveness relied upon accurate performance data, and reliable cost data. Amassing and then analyzing this information for 150 homes was a huge task and could not be accomplished immediately. In fact, the infiltration data, 
essential to accurately establish thermal performance, could not be collected until after the RCDP was complete and all homes sited. In a race against time, PNL was able to complete the infiltration study before the end of the 1989-1990 heating season; even so, this was a full year after the RCDP had ended. ${ }^{1}$ Based on modeling techniques, the analysis contractor provided an early indication of results about this same time; the real-world data would be used to verify the models and the analysis (Baylon et al. 1990).

The final thermal analysis and costeffectiveness report confirmed the earlier tentative conclusions and established that the Super Good Cents/RCDP package had been cost-effective to the region and the consumer (Baylon et al. 1991). The study included "optimization packages" that assessed individual energy conservation measures separately to determine their contribution to the costeffectiveness results. Using this information, Bonneville planned to revise the Super Good Cents specifications to call for all energy conservation measures that had proved to be cost-effective to the consumer.

The RCDP analysis had shown, however, that slightly more stringent standards could be applied and still be cost-effective for the region although not to the consumer. That is, the home owner would not save enough on energy bills to amortize the cost of the energy conservation measures but the measures would, nevertheless, save energy at less cost than the projected cost of replacing it. The manufacturers were willing to risk the higher cost of energy-efficient homes as long as the incentives were in place and as long as the home owner's cash flow was positive. From the beginning, however, they had made clear that, in their view, there was great risk in driving the costs of manufactured homes higher; this was particularly true for the "low-end" of the market.

Bonneville was not willing to "take the push" to include all regionally cost-effective energy conservation measures in its Super Good Cents specifications. The Council, on the other hand, viewed the situation as a potential lost opportunity. This was not the first time the Council and Bonneville had differed on their approach - it was the first time that the Council, in effect, helped to create a regional alternative!

\section{Hatching the Plot}

There is an inexorable logic to the way the manufactured housing project developed -- but only in hindsight. At the time, participants were struggling to maintain and expand the Super Good Cents program; coming off the "high" at the end of RCDP, that was easy enough. By the end of 1990 , over 1,000 energy-efficient Super Good Cents manufactured homes had been built and sold (BPA 1991a). Depending upon one's mood and perspective that figure was high enough and low enough to justify either optimism or pessimism. It was certainly more energyefficient homes than would have been built, maybe as many as 1,000 more. On the other hand, the industry produced over 10,000 homes per year - was the glass "10\% full or $90 \%$ empty"?

All of the taunting issues described were percolating in 1990 and one "shadow" or another had led several participants -individually and sometimes in "huddles" with one another -- to become impatient for a more direct, more dramatic approach to the challenge. A masterstroke, if you will. The movement toward hook-up fees was a symptom of this impatience. The Council's proposal to carve out the Pacific Northwest as a separate HUD code climate zone was another. The Work Group meetings provided the setting for such musings. Significantly, no one laughed on May 9, 1990, when the Super Good Cents program manager, discussing simpler approaches, had said, as quoted earlier: ${ }^{2}$ 
A wilder variation on this approach is simply to buy every home in the region and have it built to energy-efficient specifications.

it wasn't the first time participants had heard such a thought, or thought of such a direct route to acquiring the inherent conservation potential in the region's manufactured homes. And, it wouldn't be the last. In the meantime, even as participants struggled with Super Good Cents requirements and uncertainties, another more direct approach was gaining ground -more utilities were looking somewhat longingly at hook-up fees as a way to pole-vault into success.

At a meeting in the Council's Portland office in late August 1990, called by the Council to brief a small group of manufacturers and a trade association representative on the Council's recent resolution asking HUD to establish the region as a separate zone, the manufacturers dropped a bombshell. ${ }^{3}$ They raised the issue of hook-up fees, it was clear they were concerned. They had, they said, an idea that would render the issue of hook-up fees moot. They asked the Council representative what would happen if, instead of buying energy efficiency house-byhouse via Super Good Cents, the region's utilities simply paid to upgrade every manufactured home to a single regional standard!

Probably at a point even a few moments earlier in time the idea would have been viewed as preposterous. But by now even as the situation was becoming more exasperating, it was also more clearly known that the potential energy savings of energy-efficient manufactured homes were real, they could be quantified and had definite value. Manufacturers, for their part, had learned to work with utilities on an optional basis and were learning to both build and market energy efficiency as a feature of manufactured homes. In this milieu, it was not madness to suggest that, in effect, the region's manufacturer could simply wholesale energy efficiency -- deliver a walloping energy resource and with one fell swoop, end the potential battle over hook-up fees before it started, and disperse a lot of the other "shadows" as well!

Besides its positive appeal, its directness and efficiency, the Council saw this approach as a possible alternative to Super Good Cents. Perhaps it could include all regionally costeffective measures and simply bypass the disagreement over how far Super Good Cents specifications could go; Bonneville was possibly correct in its assumptions about the limitations of Super Good Cents. But if the energy savings were treated as an acquisition, from manufacturers, Bonneville could acquire all regionally cost-effective energy conservation measures and it wouldn't cost consumers a dime!

\section{Back to the Salt Mines}

Negotiations -- with all parties hardly daring to think about the difficulty and complexity of what they were doing -- began. Without much discussion, somewhat by default, the Council assumed the role of "honest broker" -- the Council had been "in the mix" from the very first Work Group meeting, its representatives were known as part of the "team," and it had the dubious distinction of being the least biased of the participants. It is significant that they were trusted as an "insider," not as an "outsider," and this alone may have justified the hours and hours the Council invested in attending the Work Group, the DMC, and the MHTAG meetings since 1986 . The manufactured housing and utility industries and other participants had come a long way toward understanding one another -- this would undoubtedly be a squabble, but it would be a "family squabble."

A working committee was formed called "the MAC," the Manufactured Housing Acquisition Committee. The program acquired a title -- MAP -- and with the title and its very own committee it gained acceptance as an idea worth investigating. The MAC was seen as worthy of the time, resources, and ingenuity 
that had wrought such change since the first RCDP test home was sited in early 1988.

Four subcommittees were established; these indicate the scope and the complexity of the undertaking. ${ }^{4}$

Product Design - Representatives of manufacturers, SEOs, the Council, and Bonneville served on this subcommittee. The essential goal of this group was to determine the specifications that would be incorporated into the final plan. This was where the issue of regional cost-effectiveness versus home owner cost-effectiveness would be threshed out. How far did the region want to go? How far could the manufacturers go? Who's in? Who's out? The ultimate goal was always $100 \%$ manufacturer participation.

Utilities - This group included representatives from all the region's utilities. Manufacturers could not participate in a regionwide scheme unless all utilities -- including the investorowned utilities -- participated. By this time, manufacturers had made their point: construction practices, plant operations, and cost-efficiency demands discouraged (and in some cases would probably prevent) customization. The industry could not be expected to build homes customized to over 100 different utility service territories. If manufacturers were to function as "one big plant," the region's utilities would somehow have to figure out how to function as "one big utility" -- something they had achieved in coordinating their resources but never done in the area of energy conservation.

On-Site Quality Assurance - Both the RCDP and Super Good Cents had taught valuable lessons about the importance of proper set-up and its impact on the energy efficiency of a manufactured home. Super Good Cents specifications required more stringent procedures and improved materials compared to current practice; now suddenly the magnitude of the challenge to expand these procedures to include all homes became apparent.
Representatives of dealers, utilities, SEOs, and set-up crews were charged with developing a viable means of ensuring that this task could be accomplished for each and every manufactured home produced and sited in the region.

Contract Development - It was apparent at the outset that Bonneville would have to function as the contracting agent -- again, experience was clear that manufacturers could not deal with over a hundred contracts and, conversely, that utilities could not deal with each of the region's manufacturers. Two agreements were necessary.

- an agreement between the utilities (including the investor-owned utilities) and Bonneville that they would reimburse Bonneville for energy-efficient manufactured homes sited in their service territory and

- an agreement between Bonneville and each manufacturer that they would be paid an incentive for the production and siting of new manufactured homes in the region that met the specifications agreed upon by the contracting parties (MCS or beyond).

\section{A Mosaic of Cooperation}

Any and all of these "variables" were in flux throughout the balance of 1991 as negotiations began. What was surprising was not that there were problems, points of disagreement, complexities no one had anticipated, or seemingly unbridgeable gaps. What was surprising was that no one "left the table." No one was willing to "lower their sights." No one "dug in." There were battle scars from RCDP and Super Good Cents but there was another legacy most vital during these ticklish times - a hint of trust.

Throughout 1991, the technical people who had labored so diligently to work out the thermal performance and cost-effectiveness analysis of the RCDP that were the underpinning and support for the Super Good Cents incentive payments shifted gears to 
develop a regionwide single standard. These MAP specifications were not fixed once and for all, they were a changing element in the negotiations. At one stage, for example, manufacturers proposed that homes with extra glazing be paid a premium MAP incentive because of the increased solar gains they achieved. Similarly, while blown-in insulation had been shown to be much more cost-effective than batt insulation and several attempts were made to incorporate this technique into the MAP specification, it was ultimately dropped because not ail manufacturers had the capacity to insulate homes in this way.

\section{MAP \\ Proposed Final Specifications}

Applicable to all zones.

No glass area limitation when a home's overall heat loss rate is equal to or less than a house built with:

- Attic area (if any) insulated to U-0.25 (R-40)

- Vault area (if any) insulated to U-0.30 (R-33)

- Walls insulated to U-0.052 (R-19)

- Floors insulated to U-0.032 (R-31)

- Windows/skylights and patio doors -U-0.35

- Doors - U-0.19 (R-5)

* R-values shown are actual "as installed" values.

What was finally crafted (see Box - MAP) was a specification that went "much farther" than the Super Good Cents specifications. In the course of discussions and in the spirit of "aiming high," the MAC subcommittee began to think in terms of a single specification for the entire region. While this would result in homes that exceeded requirements in climate zones 1 and 2, it leveled the playing field for manufacturers; and analysis revealed that the enhanced measures were regionally costeffective even in the mildest climate areas. Similarly, previous limitations on glazing area could be dropped if minimum component standards could be agreed upon. The final MAP specification had the distinction of simplifying requirements and improving energy performance.

Both the specifications and the level of incentives were "moving targets," variables in the negotiations. Achieving $100 \%$ utility participation was no small challenge and it took several "passes" before agreement was achieved. One early compromise offered by the utilities, for example, was a declining incentive. This permitted utilities to agree to an offer. In a region as diverse as the Pacific Northwest, the appeal (and value) of energy-efficient manufactured housing stock was far from universal. In the I-5 Corridor, particularly near burgeoning Seattle and Tacoma, almost any easing of energy demand requirements had appeal. But in the windswept reaches of western Montana or the high plateau of eastern Washington almost the opposite was true.

Because of the need to solidify utility participation, the public utility commissions (PUCs) of the four states in the region played a role in negotiations. The utilities were required to justify any payments for acquisition of resources and PUC regulations established costeffective limits based on each utility's least-cost planning estimate. PUCs needed to be oriented to the nature and potential value of the energy resources that were being negotiated. In turn, this eased the path to agreement for many utilities. Another hurdle for many was the contract they would be required to sign with Bonneville. An astonishing amount of detail had to be discussed and resolved.

A breakthrough of sorts helped to resolve the issues and problems connected with set-up quality control. While regional practices varied, most dealers were responsible for set-up and this had created a wide variety in set-up materials and, in turn, procedures. As the negotiations proceeded, it was proposed that set-up materials be provided by manufacturers; 


\section{MAP \\ Final Incentive Arrangements}

- Bonneville will be the program's "banker."

- Manufacturers will be reimbursed \$2,500 for each energy-efficient electrically heated home constructed to MAP specifications.

- The utilities will then pay Bonneville $\$ 2,500$ for every one of these homes sited in a utility's service territory (plus \$250 to cover BPA's costs to administer the program).

- Bonneville has agreed to serve in this capacity for at least 4 years.

- Incentive levels and other contract requirements will be reviewed every 6 months and revised when circumstances (for example, changes in the HUD code energy standard) dictate.

this would standardize materials used in the field and ensure their quality. Similar materials would go an incredibly long way toward standardizing techniques as well. It would simplify the development of set-up training and permit more specific training aids to be produced.

Another sticking point involved payment schedules. As a federal agency, Bonneville was constrained by federal purchasing and contracting regulations and schedules. Manufacturers were concerned about the tremendous increase in material costs they were being asked to incur; the industry by this time had made its point that cost control and cash flow were vital ingredients to survival, let alone success, in a price-driven industry. The "lag" in payments was tolerable when energy-efficient homes accounted for only a percentage of production. A cost increase across-the-board, however, was another matter and a complication that hadn't been anticipated.

The "Feds" proved to be a player too! Recognizing that the capitalization required was not likely to be cost-effective for anyone, Bonneville was able to institute a means to pay incentives not once but twice a month and to accomplish this via electronic funds transfer. While this flexibility cost relatively little for Bonneville to accomplish, it solved a serious problem for the manufacturers; the radically improved cash flow kept their financing costs and their risk to the minimum.

Finally, there was the matter of tracking. Each and every manufactured home in the region had to be iJentified. Was it built to MAP specs? When did it leave the plant? Who was the dealer? Where was it sited? Has it been inspected at the site? Which utility owes Bonneville repayment for the incentive? Providing instant answers to each of these questions for 10,000 homes a year posed no small challenge -- a challenge ultimately met by the ODOE which was able to design a tracking system that could serve Bonneville, each of the region's utilities, and each of its manufacturers.

In the final analysis, MAP was just another business deal. Something of value, in this case a highly abstract commodity -- potential energy - was changing hands. Manufacturers saw the transaction as a potential risk to their market, an increase in their product investment, and a decrease in their cost efficiency. They put a price on this. Conversely, utilities saw the energy savings as difficult to quantify, possibly available via other means -- hook-ups or HUD Code, and (in some cases) an unnecessary purchase. They put a price on this.

\section{Putting It All Together}

Considering the vast difference in perspective -- and of course there was a range of viewpoints within both the manufactured housing industry and the utility industry - the wonder is that negotiations were able to proceed at all. When they did, these intrinsic differences and their more numerous cousins, the nit-picking details, would -- as always -present obstacles to agreement. But the stakes were high and the track record of working out disagreement -- thanks to RCDP and Super Good Cents -- was good. In the end, a forging 
of common interest, a merger of ambitions, was achieved.

By the fall of 1991, the Council had prepared its Draft 1991 Power Plan for the region and MAP was included as a targeted action itera (NWPPC 1991). History was written inis that Power Plan; neither the Pacific Northwest nor its manufactured homes would ever be the same. For better or for worse, every elecarically heated HUD code home built in the Pacific Northwest would be built to much higher standards than anywhere else in the world. It was bound to affect not only the energy picture but the housing picture for years to come!

Of course, the HUD standards wc uld eventually change and they were bound to be at least somewhat more stringent, narrowing the gap between the efficiency of homes that is anufacturers had to build compared to what they were paid to build. But, ir the meantime, these energy savings would not be lost. Capturing available conservation was becoming

\section{End Notes}

1 Internal report on the June 27, 1990, Manufactured Housing Data Management Committee (DMC) meeting prepared July 12,1990 , by the Bonneville Power Administration, Portland, Oregon.

2 Internal report on the May 9, 1990, Manufactured Hou'ing Work Group meeting prepared June 15, 1990, by the Bonneville Power Administration, Portland, Oregon. more and more important as the Northwest load/resource balance began to shift under the pressure of continued growth. The energy surplus was fast disappearing and in the heavily populated 1-5 Corridor between Tacoma and Seattle peak loads and transmission limitations were straining utility capacity to meet demand - regardless of how much power the region as a whole might possess.

$* * * * *$

No one had to do it. But they did - the region's utilities, manufacturers, associations, energy planners, SEOs, federal agencies, the DAPIAs, the IPIAs, and the Indians too! The Pacific Northwest, as we stated at the outset, is "a unique region of surprising contrasts." Just as it pioneered in development of "the light fantastic " in the 1880 s and $1890 \mathrm{~s}$, it is pioneering the more prudent, more efficient use of electrical energy resources in the 1980s and 1990 s. The manufactured housing project and its culmination in MAP is part of that development, a respectable little saga for our time!

3 Internal report on the September 6, 1990, Manufactured Housing Technical Advisory Gro'sp (MHTAG) meeting prepared October 9, 990 , by the Bonneville Power Ad ministration, Portland, Oregon.

4 Letter from the SGC Program Manager, Residential Programs Branch, to the Manufactured Housing Program List on the MAC Background, Organization, and Timetable, April 1991. Bonneville Power Administration (BPA), Portland, Oregon. 


\section{CHAPTER 15: REFERENCES}

Balistocky, S., A. A. Bohn, J. A. Heidell, P. L. Hendrickson, A. D. Lee, R. G. Pratt, and Z. T. Taylor. 1985. Impacts of Alternative Residential Energy Standards - Rural Housing Amendments Study, Phase I. PNL-5694-1, Pacific Northwest Laboratory, Richland, Washington.

Balistocky, S., A. D. Lee, and S. A. Onisko. 1986. The Role of the DAPLA in the Manufactured Housing Process. PNL-5774, Pacific Northwest Laboratory, Richland, Washington.

Barry, D. J. and J. G. Jennings. 1991. Process Evaluation of the Super Good Cents Manufactured Housing Program. ERCE/DSM-73, prepared for the Bonneville Power Administration by ERC Environmental and Energy Services Company, Fairfax, Virginia.

Baylon, D. and B. Davis. 1992. Super Good Cents Heat Loss Reference/Manufactured Homes: Heat Loss Assumptions and Calculations: Heat Loss Coefficient Tables. Prepared for the Bonneville Power Administration by Ecotope, Inc., Seattle, Washington.

Baylon, D., B. Davis, I. Brown, M. Kennedy, M. Lubliner, and S. Onisko. 1991. Manufactured Homes Thermal Analysis and Cost Effectiveness Report. Prepared for the Bonneville Power Administration by Ecotope, Inc., Seattle, Washington.

Baylon, D., B. Davis, M. Kennedy, and M. Lubliner. 1990. Manufactured Homes Simulated Thermal Analysis and Cost Effectiveness Report. Prepared for the Bonneville Power Administration by Ecotope, Inc., Seattle, Washington, and the Washington State Energy Office, Olympia, Washington.

Baylon, D. and J. Heller. 1988. Super Good Cents Heat Loss Reference Manual. Prepared for the Bonneville Power Administration by Ecotope, Inc., Seattle, Washington.

Baylon, D., M. Lubliner, and B. Davis. 1990. Manufactured Homes Cost Data Analysis Report. Prepared for the Bonneville Power Administration by Ecotope, Inc., Seattle, Washington, and the Washington State Energy Office, Olympia, Washington.

Bleything, D. 1992. "Nailing Down a Housing Deal," Northwest Energy News. May/June 1992, Northwest Power Planning Council, Portland, Oregon.

Bonneville Power Administration (BPA). 1986. Office of Conservation: 1985 Yearbook. DOE/BP553, Portland, Oregon.

Bonneville Power Administration (BPA). 1988a. Super Good Cents: Update of Manufactured Housing Data Acquisition/Analysis. RC1.0, Portland, Oregon.

Bonneville Power Administration (BPA). 1988b. "Typical Manufactured Home Construction Versus Super Good Cents Manufactured Home Construction," RCDP Information Update, No. 1, August 1, 1988, Portland, Oregon. 
Bonneville Power Administration (BPA). 1988c. Super Good Cents: Update/Manufactured Housing. RC2.0, Portland, Oregon.

Bonneville Power Administration (BPA). 1989a. Office of Energy Resources 1987/1988 Yearbook. DOE/BP-1125 (second printing August 1990), Portland, Oregon.

Bonneville Power Administration (BPA). 1989b. "RCDP Information Update," RCDP Information Update, No. 3, January 1989, Portland, Oregon.

Bonneville Power Administration (BPA). 1989c. "Technical Findings for Manufactured Housing," RCDP Information Update, June 2, 1989, Portland, Oregon.

Bonneville Power Administration (BPA). 1991a. Energy Resources Performance Report (FY 1989 and FY 1990. DOE/BP-1373, Portland, Oregon.

Bonneville Power Administration (BPA). 1991b. Project Brief: The Residential Construction Demonstration Project. DOE/BP-1378, Portland, Oregon.

Bonneville Power Administration (BPA). 1991c. Super Good Cents Technical Specifications for Manufactured Homes. Portland, Oregon.

Ek, C. W. 1986. Air Infiltration Study of Manufactured Housing on the Tulalip Indian Reservation, Marysville, Washington. Bonneville Power Administration, Portland, Oregon.

Ek, C. W., S. A. Onisko, and G. O. Gregg. 1988. "Air Leakage Tests of Manufactured Housing in the Northwest U.S.A." Presented at the Symposium on Air Change Rate and Air Tightness in Buildings, April 16-19, 1989, Atlanta, Georgia, sponsored by the American Society for Testing and Materials (ASTM).

Fels, M. F. 1986. "PRISM: An Introduction." Energy and Buildings, Vol. 9, pp. 5-18. Berkeley, California.

Findley, R., R. W. Madden, M. Miller, C. R. Ramsay, and B. Richards. 1982. America's Spectacular Northwest. Special Publications Division, National Geographic Society, Washington, D.C.

Hendrickson, P. L., B. L. Mohler, Z. T. Taylor, A. D. Lee, and S. A. Onisko. 1985. Marketing Energy Conservation Options to Northwest Manufactured Home Buyers. PNL-5496, Pacific Northwest Laboratory, Richland, Washington.

Kimerling, A. J. and P. L. Jackson. 1985. Atlas of the Pacific Northwest. 7th ed. Oregon State University Press, Corvallis, Oregon.

Lee, A. D. and M. C. Baechler. 1990. Case Study of the Regional Manufacturers Not Participating in the Manufactured Housing RCDP. PNL-7314, prepared by Pacific Northwest Laboratory for the Bonneville Power Administration, Portland, Oregon. 
Lee, A. D. and S. A. Harkreader. 1989. Case Study of the Regional Manufacturers' Participation in the Manufactured Housing RCDP. PNL-7176, DOE/BP-13795-23, prepared by Pacific Northwest Laboratory for the Bonneville Power Administration, Portland, Oregon.

Lee, A. D., Z. T. Taylor, G. B. Parker, G. I. Wilfert, J. W. Callaway, and S. A. Onisko. 1986. Energy and Indoor Air Quality Measurements from Five Energy Conserving Manufactured Homes. PNL-6135, Pacific Northwest Laboratory, Richland, Washington.

Mohler, R. L. and S. A. Smith. 1986. Marketing Manufactured Housing under the "Super Good Cents " Program. PNL-5743, prepared for the Bonneville Power Administration by the Pacific Northwest Laboratory Richland, Washington.

Morgan, M. 1962. The Northwest Corner: The Pacific Northwest, Its Past and Present. Viking Press, New York.

Morison, S. E. 1965. The Oxford History of the American People. Oxford University Press, New York.

Munnick, H. D. 1972. Catholic Records of the Pacific Northwest. French Prairie Press, St. Paul, Oregon.

Nagda, N. L., M. D. Koontz, and H. E. Rector. 1985. Energy Use, Infiltration, and Indoor Air Quality in Tight, Well-insulated Residences. EA/EM-4117, Prepared by Geomet Technologies, Inc., for the Electric Power Research Institute, Palo Alto, California.

Northwest Power Planning Council (NWPPC). 1983. 1983 Northwest Conservation and Electric Power Plan, Volume I. Northwest Power Planning Council, Portland, Oregon.

Northwest Power Planning Council (NWPPC). 1985. Draft 1986 Northwest Conservation and Electric Power Plan, Volume 1. Northwest Power Planning Council, Portland, Oregon.

Northwest Power Planning Council (NWPPC). 1986. 1986 Northwest Conservation and Electric Power Plan, Volume 1. Northwest Power Planning Council, Portland, Oregon.

Northwest Power Planning Council (NWPPC). 1986a. "Bonneville Budget Curbs Conservation," Northwest Energy News, Volume 5, No. 5. Portland, Oregon.

Northwest Power Planning Council (NWPPC). 1987a. Energy Efficiency and Manufactured Housing in the Northwest: An Overview. Portland, Oregon.

Northwest Power Planning Council (NWPPC). 1987b. Backgrounder: The Energy Efficiency of Manufactured Housing. Portland, Oregon.

Northwest Power Planning Council (NWPPC). 1987c. "The Mobile Home Comes of Age," Northwest Energy News, Volume 6, No. 5. Portland, Oregon. 
Northwest Power Planning Council (NWPPC). 1991. 1991 Northwest Conservation and Electric Power Plan, Volume I. Northwest Power Planning Council, Portland, Oregon.

Norwood, G. 1981. Columbia River Power for the People: A History of Policies of the Bonneville Power Administration. Bonneville Power Administration, Portland, Oregon.

Onisko, S. A. 1985. Energy-Efficient Manufactured Housing. Bonneville Power Administration, Portland, Oregon.

Onisko, S. A. 1986. The Cost of Energy Efficiency in HUD-Code Manufactured Homes. Bonneville Power Administration, Portland, Oregon.

Onisko, S. A. 1989. Dealer Participation in the Bonneville Power Administration Manufactured Housing Residential Construction Demonstration Project. Bonneville Power Administration, Portland, Oregon.

Onisko, S. A. and C. W. Ek. March 1985. Thermal Performance of a HUD-Standard Manufactured Home with Passive Solar Heat Storage. Consumer Products and Services Branch, Office of Conservation, Bonneville Power Administration. Portland, Oregon.

Onisko, S. A. and R. Van Orden. 1984. Mobile/Manufactured Home Retrofit Study. Bonneville Power Administration, Portland, Oregon.

Oregon State University (OSU). 1991. Super Good Cents Manufactured Homes In-Plant Inspection Manual. Produced for the Oregon Department of Energy, with funding from the Bonneville Power Administration, by the OSU Energy Extension Program, Corvallis, Oregon.

Peters, J. S. 1992. Comparative Process Evaluation of Five Research and Demonstration Projects. Prepared for the Bonneville Power Administration by Barakat \& Chamberlin, Inc., Portland, Oregon.

Russell, P (ed.). April 1992. "Manufactured Homes: Build Energy-Efficient Product Only. Conservation Monitor, Seattle, Washington.

Schoch, Karen (editor). 1987. The Hood River Story: How a Conservation Project Was Implemented, Volume I. DOE/BP-11287-12, Bonneville Power Administration, Portland, Oregon.

Sullivan, B. 1990. "Super Good Cents Manufactured Homes: Set-Up." Videotape Study Guide. Oregon State University Extension Service, Corvallis, Oregon.

Sullivan, B. and D. Philbrick. 1990. "Building Super Good Cents Manufactured Homes." Videotape Study Guide. Oregon State University Extension Service, Corvallis, Oregon.

Tollefson, G. 1987. BPA and the Struggle for Power at Cost. Bonneville Power Administration, Portland, Oregon, U.S. Government Printing Office, Washington, D.C. 
Weakley, S. A., R. L. Eckert, and A. D. Lee. 1990. Cost Data Collection for Manufactured Homes in the Residential Construction Demonstration Project. Prepared for the Bonneville Power Administration by Pacific Northwest Laboratory, Richland, Washington. 
APPENDIX A

\section{CHRONOLOGY OF KEY EVENTS IN NORTHWEST}

MANUFACTURED HOUSING HISTORY 


\section{APPENDIX A \\ CHRONOLOGY OF KEY EVENTS IN NORTHWEST \\ MANUFACTURED HOUSING HISTORY}

Dates

Event

$\underline{1981}$

Passage of the Pacific Northwest Electric Power and

Conservation Act ("the Act") and creation of the Northwest Power Planning Council (NWPPC).

Organization of Office of Conservation at the Bonneville Power Administration.

$\underline{1983}$

NWPPC releases first Regional Power Plan and Residential Model Conservation Standards (MCS) as required by the Act.

March 16, 1983 An internal Bonneville Power Administration (Bonneville) memo recommends retrofit heat pumps in manufactured homes as a pilot program.

June 27, 1983

Issue paper draft is circulated at Bonneville and serves as a catalyst to develop a strategy for including "mobile homes" in Bonneville programs -- chiefly, at this stage, the weatherization program.

October 12, 1983

Bonneville convenes a Technical Issues Group to discuss manufactured homes (among other issues).

October 1983

Bonneville memo outlines issues of interest and concern on $U$. S. Department of Housing and Urban Development (HUD code homes. The memo suggests dealers and dealer associations as a good resource to consider on an advisory committee and expresses interest in two HUD programs: (1) HUD standards, and (2) an "Affordable Housing Demonstration Program." Bonneville also expresses an interest in participating in future 
demonstration projects, including (a) verification of heat loss methodologies, (b) determining actual energy savings of homes built to HUD's 1976 standard, (c) determining number, age, size, and location of manufactured homes sited in the Pacific Northwest, (d) determining savings and cost-effectiveness of heat pumps, (e) evaluating effects of mitigating devices and methods to reduce formaldehyde concentration levels.

$\underline{1984}$

June 22,1984

Internal Bonneville memo says preliminary investigations indicate that newly manufactured homes have the potential to offer cost benefits to the region. Homes using one-half to twothirds less energy could be developed without design or structural modifications.

November 5, 1984

A Bonneville memo proposes an Energy-Efficient Manufactured Housing Test and Marketing Program.

1985

July 1985

PNL completes draft of "Marketing Energy Conservation Options to Northwest Manufactured Home Buyers" (PNL-5496). A presentation is made to Bonneville on August 8, 1985. (Final publication date is October 1985.)

August 23, 1985

Demonstration home project contract is awarded to The Levy Partnership and Glen River Homes.

October 1985

Bonneville initiates the Residential Construction Demonstration Program (RCDP) for site-built homes.

$\underline{1986}$

June 1986

Bonneville writes up initial cost calculations of upgrade costs versus energy savings based on the five initial test homes and the 34 Tulalip Indian Reservation upgrades. It concludes prophetically, "The choice seems clear. A cash incentive paid directly to the manufacturer would benefit the region."

November 17, 1986

Bonneville creates the Manufactured Housing Work Group to establish working relationships and lay the groundwork for a regional manufactured housing energy savings program. 
1st Quarter 1987

June 1987

June 1987

1988

January 1988

March 1988

November 2, 1988

$\underline{1989}$

February 27, 1989
Bonneville cuts back all conservation programs; manufactured housing project is reduced to "bare bones" activity -- costeffectiveness studies and marketing efforts are cut to minimal levels.

NWPPC strongly supports the manufactured housing program proposal and recommends that Bonneville accelerate its efforts to develop reliable cost-effectiveness data to support a long-term program and inclusion of manufactured housing in the Agency's Super Good Cents promotion.

The Work Group meets again to resuscitate the program and recommends that manufactured homes (a) be included in the SGC program, and (b) be included in Bonneville's Residential Construction Demonstration Program (RCDP) to determine the cost-effectiveness of specified measures.

RCDP/SGC Manufactured Housing Program is officially launched. Manufacturers, dealers, utilities, and home buyers participate in program that features $\$ 2,000$ to $\$ 3,000$ incentives (varying by climate zone). Dealer incentives ( $\$ 500$ in SGC areas, $\$ 250$ in non-SGC areas) are also featured.

First RCDP/SGC manufactured home rolls off the assembly line. Even though progress the first year is uncomfortably slow (only half the RCDP target are sold by December 1988), Bonneville makes the decision to continue the program into 1989.

The Data Management Committee (DMC) is formed to coordinate and oversee data issues developing in the RCDP. It holds its first formal meeting. All meetings are formally reported.

Bonneville receives word that the 150th RCDP home has been sold. 
March 30, 1989

3rd Quarter 1989

$\underline{1990}$

June 1990

September 6, 1990

Fall 1990

1991

March 1991

July 11,1991
A Work Group meeting is held to determine the future SGC program for manufactured homes. SGC incentives of $\$ 2,000$ to $\$ 3,000$ for the balance of 1989 are authorized; incentive amounts and/or technical specifications would be reviewed and may change once the RCDP cost-effectiveness studies are complete. This landmark meeting put the region's cooperating manufacturers under an interim SGC plan.

Mason County PUD $\# 3$ initiates a proposal to charge a hook-up fee of $\$ 2,000$ on any home sited in its service territory that does not meet Bonneville's standards for energy efficiency. This includes (for the first time) manufactured homes.

(NWPPC) passes a resolution formally asking HUD to declare the Pacific Northwest a separate climate zone and establishing the MCS as the standard for that zone.

In landmark DMC meeting the group's name is changed to the Manufactured Housing Technical Advisory Group (MHTAG) and consensus is reached on its goals/purpose. DOE and HUD are invited to participate. Issues include a bombshell -concerned about hook-up fees, manufacturers broached the possibility of a region-wide acquisition of all manufactured home energy savings of a meeting at the NWPPC, and NWPPC is following up quickly.

Utilities and manufacturers begin to negotiate the possibility of requiring all manufactured homes to be built to SGC specifications -- the Manufactured Housing Acquisition Program (MAP).

Final results of RCDP published.

Utility representatives, including IOUs, meet at NWPPC headquarters to discuss and finalize a MAP offer that relies on declining payments to bridge significant differences in utility evaluation of the value of MAP. 
August 30, 1991

NWPPC presents a revised and simplified MAP proposal developed by the Acquisition Committee to utility representatives. Although additional agreement needs to be reached, the meeting's results indicate that the utility and industry groups could/should proceed to further negotiation -agreement is close. 
1
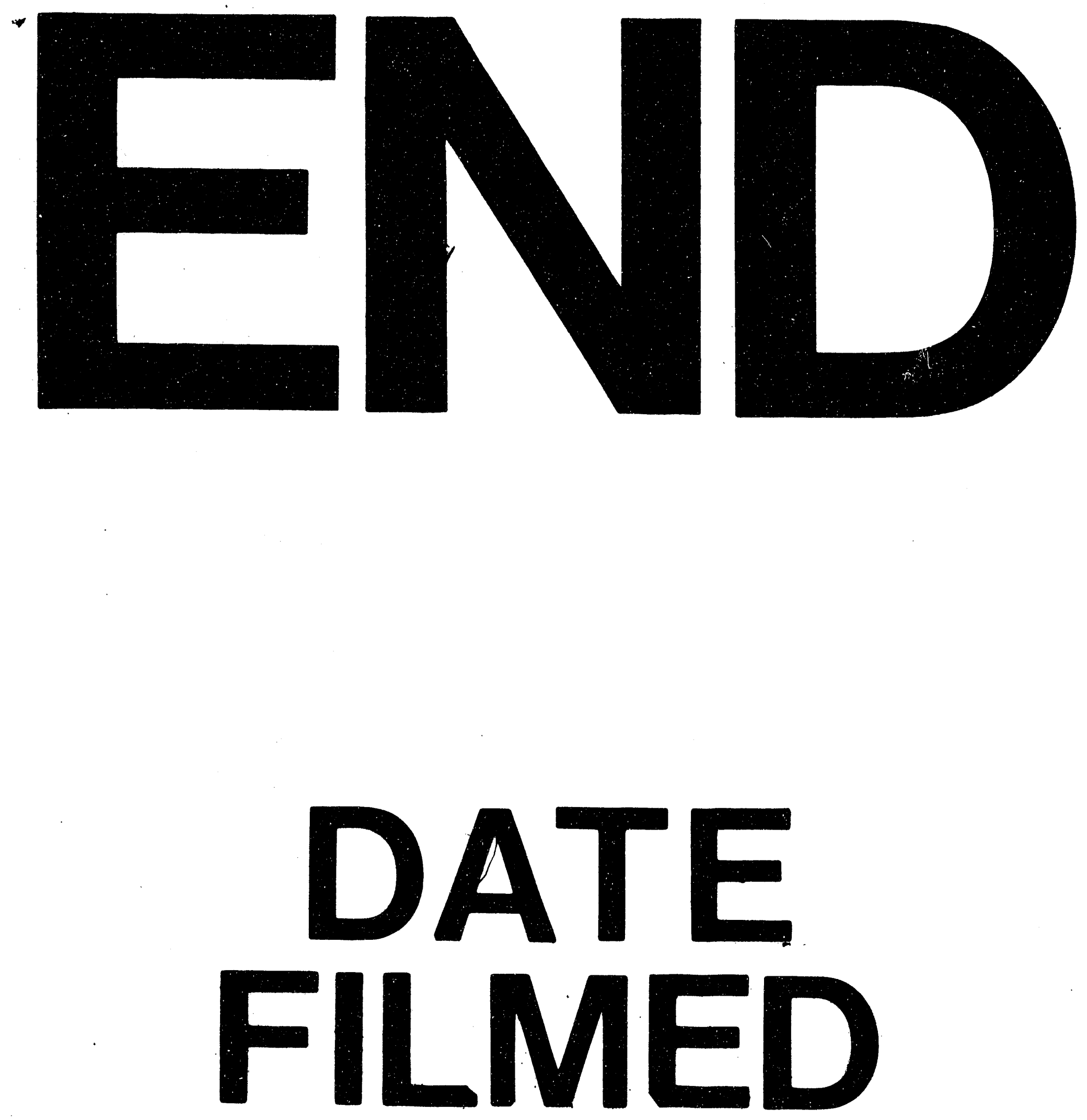

1

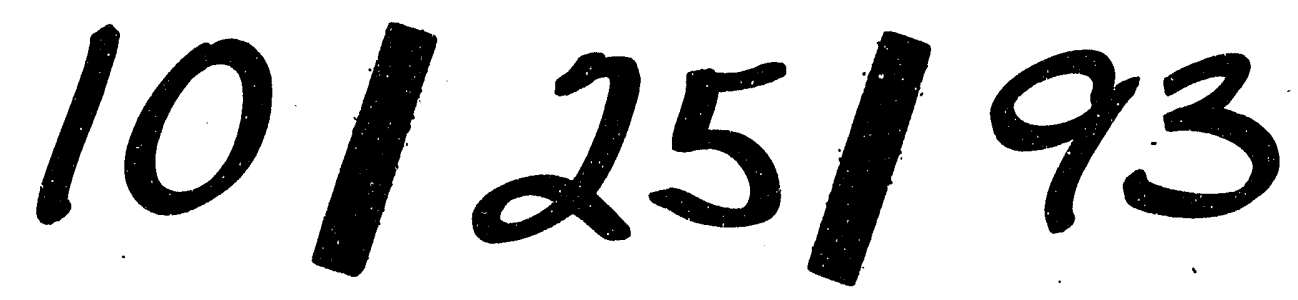


